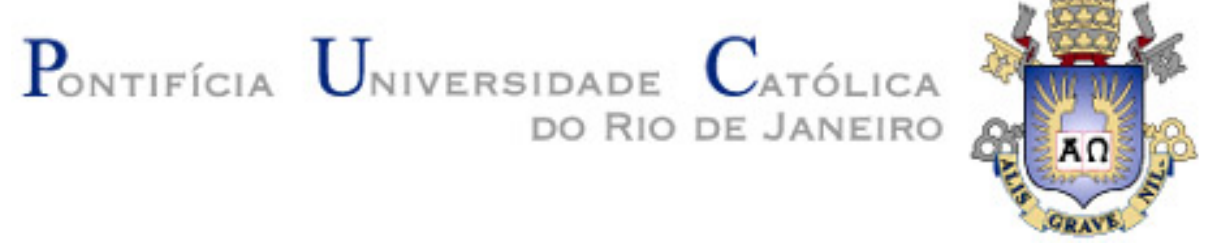

Roberto Todor

Taxonomia de Games Educativos

Dissertação de Mestrado

Dissertação apresentada como requisito parcial para obtenção do grau de Mestre pelo Programa de Pós-graduação em Design do Departamento de Artes e Design da PUC-Rio.

Orientadora: Profa. Rita Maria de Souza Couto

Co-orientadora: Profa. Cristina Portugal 


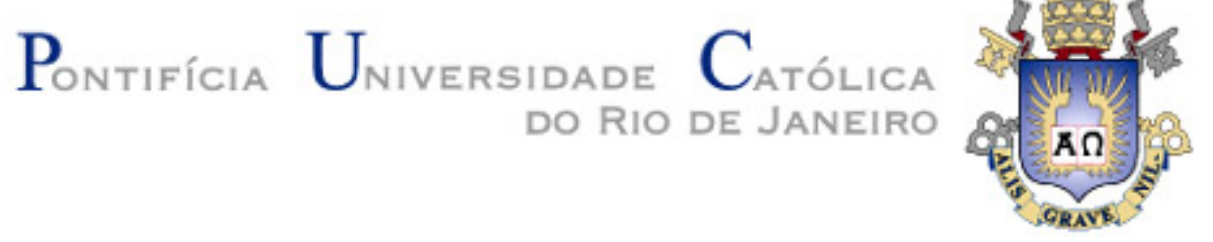

Roberto Todor

\section{Taxonomia de Games Educativos}

Dissertação apresentada ao Programa de Pósgraduação em Design da PUC-Rio como requisito parcial para obtenção do grau de Mestre em Design. Aprovada pela Comissão Examinadora abaixo.

Profa. Rita Maria de Souza Couto Orientador Departamento de Artes e Design - PUC-Rio

Profa. Cristina Portugal Co-orientadora Departamento de Artes e Design - PUC-Rio

Prof. Romulo Miyazawa Matteoni Departamento de Artes e Design - PUC-Rio

Prof. Esteban Lopez Moreno CECIERJ

Profa. Denise Berruezo Portinari Coordenadora Setorial do Centro de Teologia e Ciências Humanas - PUC-Rio

Rio de Janeiro, 12 de Março de 2015 
Todos os direitos reservados. E proibida a reprodução total ou parcial do trabalho sem a autorização da universidade, do autor e das orientadoras.

\section{Roberto Todor}

Graduou-se em Desenho Industrial (Faculdade da Cidade) em 1988. Especializou-se em Comunicação Institucional, dirigindo e produzindo audiovisuais institucionais pelo Brasil. Morou em Londres em 1990/1991, pesquisando o mercado de design, comunicação e audiovisual na Europa. Deu uma volta ao mundo em 1994/1995. Fundou a Estúdio Criatura, em 1999, que ao longo de seus 13 anos desenvolveu projetos de comunicação institucional, educacional e de responsabilidade social nas áreas de design gráfico, audiovisual, games e mídia digital.

Ficha Catalográfica

Todor, Roberto

Taxonomia para games educativos / Roberto Todor; orientadora: Rita Maria de Souza Couto; co-orientadora: Cristina Portugal. - 2015.

181 f. : il.(color.) ; $30 \mathrm{~cm}$

Dissertação (mestrado) - Pontifícia Universidade Católica do Rio de Janeiro, Departamento de Artes e Design, 2015.

Inclui bibliografia

1. Artes e design - Teses. 2. Games educativos. 3. Jogos eletrônicos. 4. Jogos digitais. 5. Objeto digital de aprendizagem. 6. Tecnologia na educação. 7. Educação. 8. Game design. I. Couto, Rita Maria de Souza. II. Portugal, Cristina. III. Pontifícia Universidade Católica do Rio de Janeiro. Departamento de Artes e Design. IV. Título. 


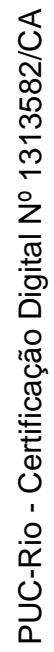

Para as minhas grandes sementes, meus filhos Joshua e Thiare. 


\section{Agradecimentos}

A minha orientadora Rita Couto e a co-orientadora Cristina Portugal, que nesse processo, me ensinaram, me apoiaram e me provocaram para fazer ainda melhor.

Ao CNPq e à PUC-Rio, pelos auxílios concedidos, sem os quais este trabalho não poderia ter se realizado.

A minha progenitora Clara Paskin Todor por todo apoio a minha educação.

A minha esposa Adriana Reis pela parceria.

A todos os meus amigos e familiares que de uma forma ou de outra me apoiaram e me estimularam nesse processo.

Aos estudantes que desejam aprender e vislumbrar um futuro melhor para o mundo e para a sua família. 


\section{Resumo}

Todor, Roberto; Couto, Rita Maria de Souza; Portugal, Cristina. Taxonomia de Games Educativos. Rio de Janeiro, 2015. 181 p. Dissertação de Mestrado - Departamento de Artes \& Design, Pontifícia Universidade Católica do Rio de Janeiro.

As tecnologias da informação e comunicação (TICs) vêm avançando de forma continuada e se amalgamando à cultura de uma grande parcela da juventude mundial, inclusive a brasileira. Nessa pesquisa, citamos o processo pelo qual está passando os espaços de ensino-aprendizagem, do qual, aos poucos, estão acolhendo a demanda desse público-alvo, de jovens estudantes, que desejam estar “conectados” durante suas atividades escolares. Contudo, muitos games com suas habilidades e competências têm contribuído para o aprendizado e podem cumprir muitas tarefas, inclusive a de reaproximar estudantes que estejam desestimulados com o ensino do dia-a-dia. A sociedade, por sua vez, vem acompanhando esse processo e, nesse documento, apresentamos um histórico de como evoluímos com os games desde os arcades até chegarem aos celulares. Como consequência dessa evolução tecnológica, há uma profusão de títulos de games para os dispositivos móveis, muitos deles educativos, o que vem de encontro com a necessidade de crianças e jovens em idade escolar. Em seguida, apresentamos um estudo dos artifícios que fazem desses games tão atrativos a esse público. Com todo esse subsídio, a pesquisa propõe a formatação de uma taxonomia para games educativos, a fim de oferecer subsídios para que alunos, seus pais e professores tenham facilidade em identificar games que possam contribuir para o seu aprendizado.

\section{Palavras-chave}

Taxonomia de games educativos; jogos digitais; objetos de aprendizado digitais; ensino-aprendizagem; tecnologia na educação, educação. 


\section{Abstract}

Todor, Roberto; Couto, Rita Maria de Souza (Advisor); Portugal, Cristina (Co-Advisor). Taxonomy of Educational Games. Rio de Janeiro , 2015. 181p. MSc. Dissertation - Departamento de Artes \& Design, Pontifícia Universidade Católica do Rio de Janeiro.

Information and communication technologies have been consistently moving forward and impacting a segment of the youth population across cultures, including Brazil. In this research paper we examine the transformations occurring in the field of education, both from a teaching and a learning perspective. These two arenas have gradually been taking on current demands from their target audience, the youth, who desire to stay "connected" while performing their typical school work. As a result, many educational games emphasizing particular skills contribute to learning and can end up playing a number of roles, one of wich is to reengage demotivated students in their day to day learning activities. Meanwhile, society as a whole has been paralleling this transformation. This paper presents a history of the evolution of games, from the arcades to the latest cell phone platforms, and how the myriad of mobile educational games has been meeting the academic needs of school age children. We present a closer look at the tools and devices that make them so attractive to this particular age segment of the population. Our research proposes the implamentation of taxonomy exclusively of educational games, aiming to facilitate their identification of games that contribute to learning for students and their parents and teachers.

\section{Keywords}

Taxonomy of educational games; digital games; digital learning objects; teaching and learning; education's technology; education. 


\section{Sumário}

1. Introdução

2. Games: como surgiram e se desenvolveram 22

2.1 Conceituação: o game estabelece uma nova cultura 36

2.2 Tecnologia em prol dos games 40

2.3 Classificação dos games: segundo sua função, seus componentes e profissionais de equipe

3. Games: e seu potencial educacional e pedagógico 58

3.1 Público-alvo: nossos usuários já nasceram na era digital 59

3.2 Educação: o processo de evolução da tecnologia no ambiente de ensino-aprendizagem 62

3.3 Design: a simples complexa interface 77

3.4 Motivação: obtendo o estado de "fluxo" no aprendizado 90

4. Games educativos: seu uso no ambiente de aprendizado 101

4.1 Agregando valor aos games educativos 110

4.2 Recomendações de games educativos 117

4.3 Eventos e associações de games educativos 134

5. Taxonomia de games educativos 137

5.1 Apoio ao docente: selecionando games para seus alunos 165

6. Considerações finais 169

7. Referências bibliográficas 175 


\section{Lista de Figuras}

Figura 1. Monkey Bubbles $\quad 46$

Figura 2. Assassins Creed (Brotherhood) 47

$\begin{array}{ll}\text { Figura 3. Advergame da Lacta } & 47\end{array}$

Figura 4. Flight Simulator $2015 \quad 47$

$\begin{array}{ll}\text { Figura 5. Exergames em academia } & 48\end{array}$

Figura 6. Gamificação na escada do metrô 48

$\begin{array}{ll}\text { Figura 7. Kiduca } & 119\end{array}$

$\begin{array}{ll}\text { Figura 8. Mangahigh } & 119\end{array}$

Figura 9. OJE - Olimpíadas de Jogos Digitais e Educação 120

Figura 10. VIVAZ - o jogo do conhecimento 120

Figura 11. World Math Day 121

Figura 12. Alberta Government 121

Figura 13. Escola Digital 122

Figura 14. Funbrain 122

Figura 15. Ludo Educativo 122

$\begin{array}{ll}\text { Figura 16. My Math } & 123\end{array}$

Figura 17. Bloody Typing Game 123

$\begin{array}{ll}\text { Figura 18. Cidade verde } & 124\end{array}$

$\begin{array}{ll}\text { Figura 19. Mito da Caverna } & 124\end{array}$

Figura 20. Operação Cosmos 125

Figura 21. Tríade 125

$\begin{array}{ll}\text { Figura 22. Capoeira legends } & 126\end{array}$

$\begin{array}{ll}\text { Figura 23. Civilization } & 126\end{array}$

$\begin{array}{ll}\text { Figura 24. Minecraft } & 127\end{array}$

$\begin{array}{ll}\text { Figura 25. The Sim City } & 127\end{array}$

$\begin{array}{ll}\text { Figura 26. Zoo Tycoon } & 128\end{array}$

$\begin{array}{ll}\text { Figura 27. ABCya! } & 128\end{array}$

$\begin{array}{lr}\text { Figura 28. Brainrush } & 129\end{array}$

$\begin{array}{ll}\text { Figura 29. Fazgame } & 129\end{array}$

$\begin{array}{ll}\text { Figura 30. Mit Game Lab } & 130\end{array}$ 
Figura 31. Smart Notebook

$\begin{array}{ll}\text { Figura 32. } A B C \text { Words } & 131\end{array}$

Figura 33. Alphabet Car Lite 132

Figura 34. Cut The Rope 132

Figura 35. Letroca 132

Figura 36. Toca Tea Party 133

Figura 37. Turma do Lilo 142

$\begin{array}{ll}\text { Figura 38. FIFA } 2014 & 143\end{array}$

Figura 39. Audiogame.net 143

$\begin{array}{ll}\text { Figura 40. The Sims } & 144\end{array}$

Figura 41. Scrabble 154

Figura 42. Angry Birds 154

Figura 43. Civilization VI 155

Figura 44. Math Racing Equations 155

Ð $\quad$ Figura 45. Bidmas Blaster (Mangahigh) 156

Figura 46. Painting (ABC Mouse) 156

Figura 47. Lego Super Heroes 157

$\begin{array}{ll}\text { Figura 48. Solitare } & 157\end{array}$

Figura 49. Tetris 158

Figura 50. Age of Empires $3 \quad 158$

Figura 51. Turma do Lilo 159

Figura 52. Mito da Caverna 160

Figura 53. Zoo Tycoon 160

Figura 54. Portal ABC Mouse 165

Figura 55. Portal ABC Ya! 166

Figura 56. Portal Bitesize 166

Figura 57. Portal Brain Pop 166

Figura 58. Portal Escola Digital 166

Figura 59. Portal Escola Games 167

$\begin{array}{ll}\text { Figura 60. Portal Funbrain } & 167\end{array}$

$\begin{array}{ll}\text { Figura 61. Portal Learn Alberta } & 167\end{array}$

$\begin{array}{ll}\text { Figura 62. Portal PHET } & 168\end{array}$

$\begin{array}{ll}\text { Figura 63. Portal Smart Kids } & 168\end{array}$ 


\section{Lista de Diagramas}

Diagrama 1. Evolução dos games 23

Diagrama 2. Fluxograma da expressão criativa ao game 39

Diagrama 3. Equipamentos para se jogar games 41

Diagrama 4. Softwares utilizados para o desenvolvimento de games 44

Diagrama 5. Meios de acessar os games e informações através da internet $\quad 45$

Diagrama 6. Organograma da equipe para a produção de games $\quad 56$

Diagrama 7. Comparativo de simultaneidade das atividades de mídia $\quad 59$

Diagrama 8. Fluxograma de atividades de um aluno de 10 anos $\quad 60$

Diagrama 9. Comparação entre as estruturas de narrativa entre mídias

Diagrama 10. Desligando-se das "atividades" digitais para ir à escola

Diagrama 11. Modelo educacional com sala de aula invertida 68

Diagrama 12. Mapa de ambiente educacional hipermídia 69

Diagrama 13. Combinação entre os campos da educação, design e tecnologia

Diagrama 14. Resultado da conjunção dos campos da educação, design e tecnologia

Diagrama 15. Interdisciplinaridade: arte, ciências e tecnologia 82

Diagrama 16. Novo Mundo, Novo Homem e Nova Cultura 83

Diagrama 17. Interdisciplinaridade:design, ciências e tecnologia 83

Diagrama 18. Canal de Fluxo 94

Diagrama 19. Diversidade de ferramentas digitais para pesquisa

e produção de conteúdo

Diagrama 20. Levantamento do tempo diário do consumo $\begin{array}{ll}\text { de mídia digital } & 107\end{array}$

Diagrama 21. Game de Entretenimento x Game Educativo 108

Diagrama 22. Cérebro do game educativo 110

Diagrama 15. Processo de montagem taxonômica com teste de classificação 
Diagrama 16. Processo de montagem taxonômica com segmentos

Diagrama 17. Processo de montagem taxonômica em forma de organograma

Diagrama 18. Taxonomia de Games Educativos Final 


\section{Lista de Quadros}

Quadro 1. Levantamento do mercado mundial de games de 2012 até 2016

Quadro 2. Respostas tecnológicas $x$ respostas construtivistas

Quadro 3. Quadro distinguindo as motivações intrínseca e extrínseca

Quadro 4. Quadro de Recomendação de Games Educativos e afins

Quadro 5. Dinâmica: 32 variáveis 
Até recentemente, para se educar as crianças utilizavamse de livros, textos, enciclopédias (quando tinham uma), bibliotecas (se havia disponível e se era boa) e algumas perguntas dirigidas a um professor já sobrecarregado. Isso costumava funcionar para os bons alunos, mas não para a maioria.

Marc Prensky, Aprendizagem baseada em jogos digitais (2010) 


\section{1.}

\section{Introdução}

Na minha juventude joguei muitos jogos, de tabuleiros e cartas, não perdia uma ocasião de estar com amigos em volta de uma mesa ou tabuleiro para jogar.

Jogar era uma estratégia muito eficiente de estar com os amigos para viver momentos de descontração, diversão e porque não dizer, também, de aprendizado. Ao jogar WAR (Estrela S.A.), eu aprendi ainda criança, que a Mongólia ficava na Ásia Central, Madagascar no Leste da África e que a Nova-Guiné é uma das muitas ilhas da Oceania.

Desta forma, percebi que o ato de jogar podia me oferecer algumas outras habilidades e competências além de entreter. Com o passar dos anos, os jogos e a tecnologia da informação evoluíram, contribuindo um para o outro, a ponto de estabelecerem uma nova cultura contemporânea que, hoje, envolve milhões de pessoas pelos quatro cantos do planeta.

Apesar dos jogos convencionais serem os veículos mais antigos e respeitados no âmbito da educação, os jogos eletrônicos ou games, por sua vez, passaram a apresentar um diferencial em relação aos meios tradicionais de entretenimento como filmes, livros, música, porque distintamente desses meios os games são participativos. Em vez de simplesmente assistir a um filme, ler um livro, ou a ouvir música, o jogador se mantém ativamente envolvido no game, como um personagem atuante que interfere em sua narrativa. Sem que haja nenhuma intenção em desqualificar os outros meios, igualmente importantes para a sociedade do conhecimento, apenas exaltando o diferencial dos games com suas interações e simulações.

Com isso, muitos jovens aprendizes, não só devido aos games, mas também a todo universo digital, se sentem mais confortáveis com os equipamentos do que com seus professores e pais. Para o matemático americano Seymour Papert (1994), entender tal relacionamento será crucial para a nossa habilidade de moldar o futuro.

Nesse processo, ao nos apropriarmos de novos paradigmas para o aprendizado desses jovens estudantes, vamos de encontro ao um novo campo de 
conhecimento onde se apresenta uma das ferramentas digitais que vem proporcionando mudanças na relação do ensino-aprendizagem: os games educativos.

Esta dissertação tem como tema uma proposta para a taxonomia desses games educativos e visa estabelecer uma investigação sobre esse perfil de objetos digitais de aprendizagem com o intuito de organizá-los, classificá-los e exemplificá-los.

Esta proposta vem contrapor-se a um problema que a educação formal não tem acompanhado as mudanças impostas pela "sociedade do conhecimento", de acordo com Silva (2010), em função da percepção de que a informação, a comunicação e o conhecimento gerados tornam-se recursos estratégicos e os agentes transformadores dessa sociedade. Com o avanço da tecnologia da informação e comunicação (TICs), suas mídias e seus produtos deslumbrantes, as crianças, os jovens e inclusive os adultos se encantam com seus constantes lançamentos e inovações. Famílias inteiras vêm desvendando a cultura informática que, por sua vez, com o advento dos games esse processo pareceu simples, segundo o educador Silva (2010), o que provocou a aculturação às novas tecnologias da informação. Consequentemente, os pedagogos e educadores passaram a ser cobrados por seus aprendizes, que precisam alinhar aquilo que melhor sabem fazer em seus campos de conhecimento com esta nova realidade.

O Brasil, por sua vez, carece não só de mais objetos digitais de aprendizagem na nossa língua e que sejam tematizados com os padrões culturais das regiões brasileiras, mas, também, de portais que organizem esses objetos e que sejam constantemente atualizados com novos produtos. E ainda, são poucos os portais que incluem games educativos, apesar da crescente demanda.

A presente investigação tem como objetivo auxiliar o vasto público inserido no ambiente educacional formal sejam eles estudantes, pais ou profissionais de educação para identificar o tipo de game que deve ser indicado para o aluno em seu processo de construção do conhecimento.

Para alcançar esse objetivo foi utilizada a metodologia de pesquisa aplicada, de forma qualitativa. A partir de uma ampla pesquisa bibliográfica digital, além de consultas editoriais, o documento organiza e exemplifica segmentos de games educativos, fundamentado em dados colecionados ao longo dessa pesquisa.

Por sua vez, os autores que serviram como bases para a fundamentação teórica foram: para a educação, o educador português Rui Canário, autor do livro “A escola tem futuro?”, assim como, o sociólogo brasileiro Marco Silva com o 
seu livro “Sala de aula interativa”; para os games de entretenimento, o game designer americano Chris Crawford, que nos anos 1980 apresentou uma primeira taxonomia para os games. Em relação aos games educativos o pedagogo brasileiro João Mattar, que ministra palestras e cursos sobre a tecnologia aplicada a educação; para tratar do público-alvo o consultor educacional holandês Win Veen, igualmente, desenvolve pesquisas de campo sobre os novos conceitos de aprendizagem, e ainda a respeito de ensino-aprendizagem com base tecnológica o game designer americano Mark Prensky, escritor e palestrante internacional sobre aprendizagem baseada em jogos digitais desenvolveu renomados estudos.

A partir desse levantamento, a presente pesquisa aborda no capítulo 2, o processo pelo qual os games surgiram e se desenvolveram impulsionados pela globalização.

Em um mundo que foi se tornando cada vez mais “digital” ao longo dos anos 1980, o videogame se populariza como item de entretenimento e passa a ser chamado de "game" por todo o seu público mundial, inclusive no Brasil. Por essa razão, a pesquisa passa a adotar a nomenclatura de game ao se referir ao jogo eletrônico ou jogo digital. Curiosamente no Brasil, os jogadores das gerações mais recentes que já cresceram com a oferta de games, se referem a eles apenas como jogos.

Estabelecida a demanda com metodologias voltadas para a tecnologia de informação e comunicação (TICs), convém explicitar que tipo de equipamentos (hardwares) constituem esse sistema, e também se faz necessário indicar os vários programas (softwares) que temos disponíveis para desenvolver um melhor e amplo uso dos games. A presente pesquisa, ainda exemplifica as classificações funcionais dos games, como, por exemplo, a identificação de games de entretenimento, games sérios, exergames, advergames e simuladores.

Para desenvolver títulos voltados para a educação, é necessário que os games educativos sejam elaborados por uma equipe multidisciplinar com profissionais das áreas da educação, design, tecnologia dentre outras. Essa composição viabiliza a produção de games que tanto devem estar comprometidos com o currículo e o aprendizado, serem atrativos e divertidos, assim como, eficientes e intuitivos. Além disso, é apresentado um detalhamento de quem são os profissionais que desenvolvem esses games e, também, lista um glossário com palavras, termos técnicos e científicos em torno dessa atividade. 
Os alunos, se já não estão familiarizados com todos esses termos, precisam ser alfabetizados digitalmente. Para isso, é necessário termos conhecimento de como envolvê-los pedagogicamente nesse processo. Os games se estabeleceram como produtos de diversão e entretenimento, mas apesar disso, como é relatado no capítulo 3, também passaram a servir como um excelente instrumento de informação e aprendizagem. De acordo com Papert (1993), o uso do computador deve auxiliar nesse processo de construção de conhecimentos, como uma poderosa ferramenta educacional, adaptando os princípios do construtivismo cognitivo de Jean Piaget, a fim de melhor aproveitar-se o uso de tecnologias para essas gerações de jovens.

Nesse mesmo capítulo, destacamos algumas questões em torno dos indivíduos dessa geração nascida em meio a computadores, internet, games e tantos outros recursos digitais chamados de "nativos digitais” por Marc Prensky (2008), e incorporaram de tal forma essas mídias que sequer as percebem como tecnologia. Para eles, o acesso à informação deve ser rápido, quase imediato e, por isso, recorrem à internet ao invés de meios impressos tradicionais.

A escola precisa desempenhar o papel de preparar os estudantes para acompanhar essas mudanças do mundo contemporâneo. E não basta prover o professor com conhecimento sobre computadores. Segundo José Armando Valente (1991) a instituição deve propiciar a vivência de uma experiência que contextualize o conhecimento que ele constrói. A implantação da informática educacional, como auxiliar no processo de construção de conhecimento, implica mudanças na escola que vão além da formação do professor, ao envolver além de alunos e professores, os administradores e a comunidade de pais.

Por exemplo, quando Jean Piaget e Constance Kamii (1990), nos falam que é necessário que a criança pegue, junte, separe, aperte, arranje, distribua, enfim, movimente objetos a fim de construir conceitos e realizar ações próprias do conhecimento, podemos encontrar algumas dessas demandas de habilidades em games educativos e afins.

Para isso, precisamos que os designers “modelem” essas questões e tantas outras, para torná-las de mais fácil compreensão aos jogadores. Em se tratando de games educativos, essa pesquisa indica um estudo sobre a necessidade da interseção entre as áreas educacionais, tecnológica e design. Essa simbiose é fundamental para 
que o ambiente simulado nos games permita ao jogador se envolver virtualmente com as questões apresentadas dentro de um processo de aprendizagem.

O objetivo dessa interatividade serve para proporcionar mais envolvimento o engajamento do aluno no processo de seu aprendizado. Como os games podem oferecer tais possibilidades de conexão, pode ser relatado através das pesquisas sobre fluxo e experiências autotélicas desenvolvidas pelo psicólogo húngaro Mihály Csikszentmihalyi desde os anos 1970.

Decorrente do sucesso dos games de entretenimento houve o surgimento de aprendizagem baseada a partir da tecnologia desses games, apresentado no capítulo 4 o que ocorreu nas últimas décadas do século 20, época do boom da tecnologia global.

Em relação a qualidade tecnológica a ser aplicada à educação, o americano James Paul Gee (2005), que é referência mundial no uso de games em educação, chama a atenção para a disparidade que a cultura do videogame pode gerar, em função de restrições de acesso para a população mais pobre e menos instrumentalizada.

Apesar do atraso ao acesso da informática do Brasil em relação a outros países, mais de metade das escolas públicas já se aparelharam com laboratórios de informática, o que se tornou política pública no país. Para incrementar esse processo temos o Projeto de Banda Larga nas Escolas (PBLE) e o Projeto Um Computador por Aluno (PROUCA).

O passo seguinte ao aparelhamento escolar e a utilização das TICs é criar novas metodologias educacionais que façam uso de objetos de aprendizado digitais, como consultas a informação e textos através da internet, videoaulas, vídeos, games educativos, exercícios digitais, classificadores de conteúdo, editores de vídeo e áudio, infográficos etc. Os alunos, ao usarem o computador de maneira dinâmica e divertida, aprendem através do uso da tecnologia e se apropriam de ferramentas que as mídias digitais oferecem e que podem auxiliá-los nas demandas de seu desenvolvimento escolar e posteriormente em sua vida profissional.

Também é citado nesse capítulo, a atribuição dos bons méritos ao uso de games com crianças e jovens com necessidades especiais, segundo o psicólogo inglês Mark Griffiths (2011). A pesquisa apresenta alguns exemplos de games desenvolvidos especialmente para portadores de deficiências visuais, auditivas e cognitivas. 
No universo educacional, já são conhecidas e praticadas atividades lúdicas em meio às tradicionais, entretanto, quais seriam as vantagens apresentadas pelas mídias digitais ou mais precisamente pelo game educativo, que é especificamente o objeto de investigação da presente pesquisa? E quais os valores agregados a esse perfil de atividade? Para responder a essas perguntas, a pesquisa identifica alguns desses valores a partir da composição de três distintas áreas: a ciência (psicologia), a educação (pedagogia e didática) e a tecnologia (design e sistemas).

E quais os games que podem contribuir tanto para a educação quanto para o futuro profissional desses alunos? Para isso, foi feito um levantamento a partir de alguns títulos que se destacaram nesses últimos anos pelos minigames educativos, games sérios, games educacionais para dispositivos móveis, plataformas de games educativos e softwares de autoria.

Com a crescente demanda por objetos de aprendizagem digitais, os projetos de games educativos vêm ganhando destaque nos eventos de games, assim como, em eventos voltados para a educação. Entretanto ainda não há um evento ou associação específicos só para games educativos. Na pesquisa, é apresentada a única associação de games nacional e uma relação de eventos que ocorrem ao longo do ano no Brasil, no qual se pode perceber um aumento de desenvolvedores de games voltados para a educação.

Após os estudos e análises, a pesquisa chega a um ponto crucial ao organizar e categorizar os games que oferecem propósitos educativos, alguns deles de forma não intencional. No capítulo 5 é apresentado um levantamento com os mais variados tipos de games e, uma vez selecionados, os que poderiam ser classificados como de apoio a atividades educativas. Foi criada uma taxonomia a fim de identificá-los, classificá-los e descrevê-los, a partir de oito etapas: tipo de segmento, nível escolar, temas educacionais, hardware, software, configuração do jogo, estilo e jogabilidade, distribuídos em 13 variáveis, por sua vez, segmentadas em 94 sub-itens.

Contudo, para auxiliar os usuários - estudantes, pais ou professores - a identificar o tipo de game que esteja buscando, os portais precisam oferecer filtros específicos que contribuam para essa seleção. Ao fim da pesquisa, foi feito um levantamento de portais educacionais nacionais e internacionais e apresentados seus respectivos filtros de seleção. 
Dessa forma, sugerimos uma taxonomia para games educativos e apresentamos games e portais disponíveis na internet com o intuito de contribuir para um novo paradigma de aprendizado, que vem ao encontro da demanda dos estudantes de hoje, do séc.XXI, do mundo globalizado, da informação, do digital e virtual. 
2.

\section{Games: como surgiram e se desenvolveram até hoje}

O avanço tecnológico dos jogos eletrônicos, desde os primórdios dos anos 1950, fez com que os jogos se transformassem em produtos acessíveis e extremamente inovadores nos anos 1970, quando passaram a ser chamados de vídeogames, em consequência da cultura audiovisual da época. Com a globalização e o universo se tornando cada vez mais digital nos anos 1980, os vídeogames se modernizam e passam a ser popularmente chamados de games nos quatro cantos do planeta. E o vídeogame chega ao nosso dicionário de português, incluindo a contração "game", assim:

Vídeogame /'v'diowgejm/ [Ing.] s.m. (c1973) jogo eletrônico jogado por meio de imagens em uma tela; videojogo, game.

Fonte: Dicionário Houaiss

Essa transformação semântica é consequência de um processo extremamente complexo, proveniente de muitas vitórias e derrotas. E nesse processo, a palavra "game" será tratada na pesquisa como uma expressão coloquial da nossa língua portuguesa, referente a vídeogame.

Os games, que hoje constituem uma das mais populares formas de entretenimento em nossa sociedade atual, podem oferecer uma partida para um jogador jogar sozinho ou junto com dezenas de pessoas de todos os cantos do planeta em seu computador, laptop, tablet ou celular. Contudo, sua história aconteceu entre momentos de euforia e de grandes fracassos e se estabeleceu de tal forma, que ultrapassou recentemente, em faturamento, a indústria do cinema.

A seguir, será apresentada uma linha do tempo com uma seleção do que pareceu mais pertinente, a fim de ilustrar o processo pelo qual os games atravessaram até chegarem em sua configuração atual. Não serão contemplados todos os fatos que aconteceram em sua história, porque foram tantos e tantas as variáveis que cada autor ou fonte contempla informações diversas.

Após o advento dos Jukeboxes e Fliperamas, o primeiro registro de experimento para um jogo eletrônico foi desenvolvido, em 1947, por dois 
pioneiros da televisão americana e especialistas em tubos de raios catódicos. Inspirado nas telas de radares, um ponto simulava mísseis que deveriam acertar um círculo, eram controlados por botões analógicos em um painel do equipamento. Porém, tanto essa como outras experiências, que viriam a se chamar inicialmente de jogos eletrônicos, eram limitadas aos frequentadores de exposições científicas, laboratórios universitários e instalações militares.

Novak (2010) comenta que esses frequentadores eram os programadores e pesquisadores insones que, apesar do excesso de trabalho, transformavam seus equipamentos de pesquisa em máquina de jogos como uma maneira de relaxar de suas complexas pesquisas. Trabalhando de madrugada, esses pioneiros deram início ao que vem se tornando uma das formas de entretenimento mais irresistíveis do mundo contemporâneo dos experimentos com o osciloscópio aos sensores de movimento (Figura 1).
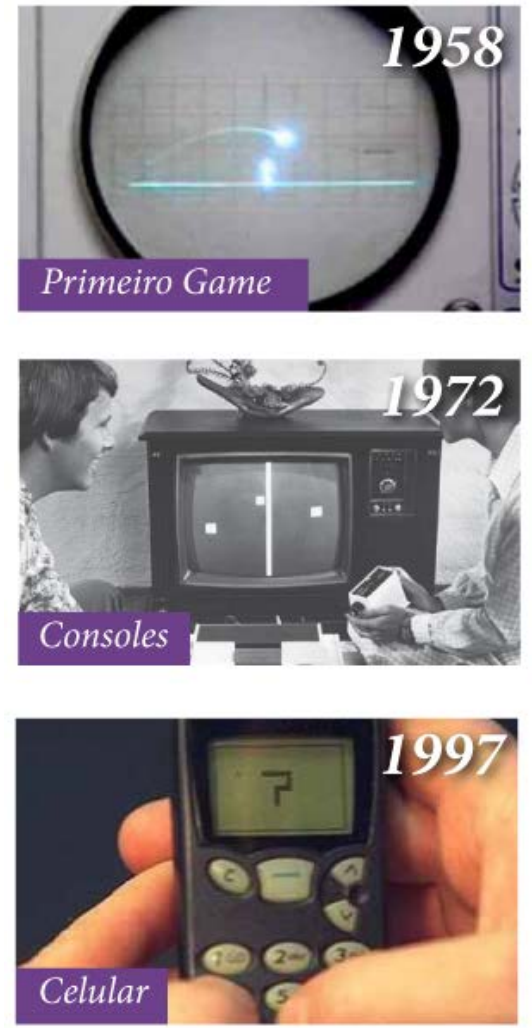
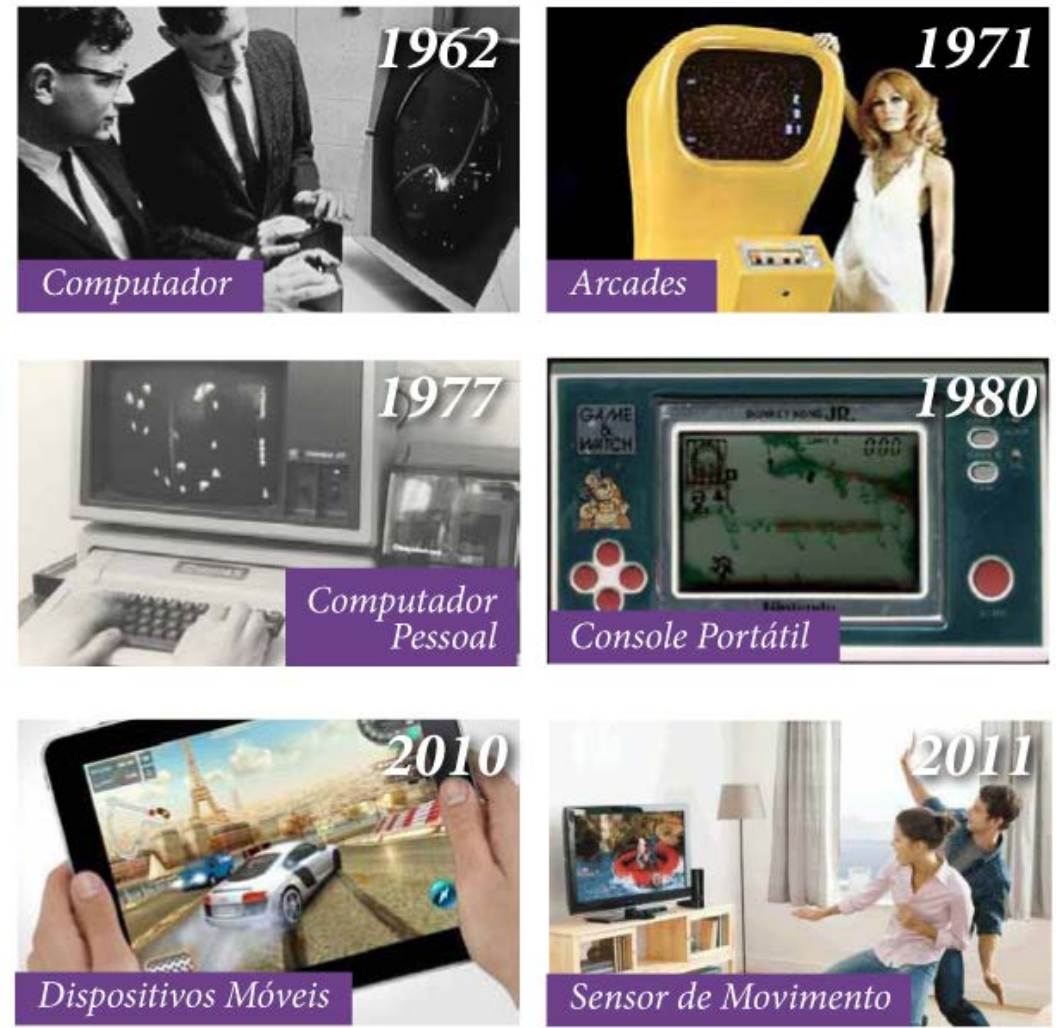

Diagrama 1. Evolução dos games Fonte: O autor 


\section{Anos 1950}

Em 1951, a empresa inglesa de equipamentos elétricos Ferranti desenvolve o computador NIMROD. Com três metros de comprimento, dois metros de altura e um metro de profundidade foi construído para executar exclusivamente o jogo NIM.

De acordo com Goularte (2010), um ano depois em 1952, Alexander S. Douglas em sua tese de doutorado pela Universidade de Cambridge, demonstrou a interação humano-máquina com o computador EDSAC, uma versão de jogo da velha (chamada de OXO). O jogador discava um número que representava o local de sua jogada.

Em 1958, William A. Higinbotham, do Brookhaven National Laboratory (centro de pesquisa nuclear de Nova Iorque), apresentou o que seria o primeiro videogame que ficou conhecido como: Tênis para dois (Tennis for two) (ROYO, 2008). Esse game foi desenvolvido em um osciloscópio, no qual era possível manipular um ponto de luz de um lado para o outro da tela, através de dois controles remotos básicos com um mancho e um botão, cada um.

Em 1959, foi criado o que para alguns especialistas foi primeiro jogo eletrônico para o computador TX-0 na MIT (Instituto de Tecnologia de Massachusetts. O game Mouse in the maze usava uma caneta ótica como controle para posicionar o labirinto e um ponto virtual representava o rato que deveria coletar o queijo através do labirinto. Também criaram o Tic-tac-toe, uma versão de jogo da velha, jogada com a mesma caneta ótica.

\section{Anos 1960}

Em 1962, no mesmo MIT com o computador DEC (quase do tamanho de um carro) os alunos Wayne Witanen, Martin Graetz e Steve Russell, fãs de livros e filmes de ficção científica tiveram a radical ideia de programar algo interativo que simulasse uma batalha espacial. Russell finalmente completou em 1962 a primeira versão do jogo chamado Spacewar! (mais tarde vai se transformar em Asteroids nas mãos de Nolan Bushnell criador do console Atari). O tema é o conflito de duas naves controladas por quatro interruptores (switches): movimento horário ou antihorário, torpedos e aceleração. Logicamente, o fato de pouquíssimas pessoas terem acesso a computadores em 1962 impedia qualquer chance do jogo romper as 
barreiras de um limitado público universitário. Por essa limitação, os jogos eletrônicos representavam experimentos baseados nos seriados e revistas em quadrinho da época (GULARTE, 2010).

Apesar das limitações iniciais, nessa década se estabeleceu um grande avanço tecnológico que possibilitou imensas oportunidades para os anos que estavam por vir.

\section{Anos 1970}

Enquanto que nos EUA e na Europa se iniciaram os primeiros investimentos no mercado comercial de jogos eletrônicos, no começo dessa década, aqui no Brasil só se conheciam máquinas de jukebox e pinball.

Em 1971, dois estudantes da Universidade de Stanford, inspirados no Spacewar!, criaram o Galaxy Game em um computador PDP-11, um monitor e dois controles fixos no painel com manche e botão, caracterizando assim o equipamento “arcade”. Cada jogada custava 10 centavos de dólar. Esse produto se tornou um fracasso, devido ao seu exorbitante preço de 20 mil dólares (GOULARTE, 2010).

Logo em seguida, os americanos Nolan Bushnell e Ted Dabney desenvolvem um jogo eletrônico com um arrojado design para um arcade, também baseado no Spacewar! chamado de Computer Space. Foram produzidas 1.500 unidades, porém o projeto não teve boas repercussões atribuídas ao seu extenso manual de instruções.

Percebendo o potencial do mercado, o mesmo Nolan inaugura a Atari Inc. em 27 de junho de 1972, que se torna uma das principais empresas de videogame dos anos 1970 e 1980. É lançado o arcade com o jogo eletrônico Pong, que se torna um sucesso de vendas e que em menos de um ano vendeu 10.000 unidades (GOULARTE, 2010).

Com o avanço tecnológico da informática, da televisão e a massiva popularização dos jogos eletrônicos nos anos 1970, a palavra inglesa videogame é incorporada ao vocabulário comum no Brasil, e um pouco depois venha a sofrer uma redução e ser chamado popularmente de game pelos quatro cantos do planeta.

Enquanto isso, a Magnavox lança o primeiro e revolucionário console com o jogo Odissey. Sua proposta de marketing não foi bem recebida, porque passou a 
falsa impressão de que só funcionaria com o televisor Magnavox sendo descontinuado em 1974. Nesse mesmo ano, a Kee Game que comercializava o arcade Tank, se funde com a Atari. Em 1975, a Atari lança a sua primeira versão de console com o jogo eletrônico Pong (incluindo o conhecido beep), sendo que a concorrente não tinha áudio. Ao longo de 5 anos, a Atari produz jogos pioneiros e que servirão como inspiração para os futuros games. Foi a primeira empresa a criar máquina com jogabilidade para quatro jogadores (Pong Doubles, 1973): o primeiro jogo de corrida (Gran Trak 10, 1974); o primeiro jogo do tipo scroll vertical com cabine (Hi-way, 1075); e o primeiro jogo de corrida em primeira pessoa (Night Driver, 1976), (GOULARTE, 2010).

Lançado em 1975, o primeiro jogo eletrônico exportado pelo Japão foi o “Gun Fight” da japonesa Taito, no qual dois caubóis se duelavam.

Apesar do momento parecer promissor, surge uma crise no setor de jogos eletrônicos para consoles. O processo de design dos jogos, na maioria dos casos, era desenvolvido pelos próprios programadores e analistas. Foram criadas versões muito semelhantes umas das outras e que costumavam oferecer somente novos níveis de dificuldade alterando a jogabilidade, mas não ofereciam experiências inovadoras para o usuário. Além disso, a expansão e a quantidade de máquinas Pong e seus clones de diferentes jogos do mercado de arcades, causaram um esfriamento e um princípio de crise no mercado de consoles.

Enquanto isso, a primeira geração de jogos eletrônicos para computadores pessoais eram apresentados através de revistas impressas com conteúdo técnico para computadores Apple, Comodore e Tandy; tornando-se pela sua complexidade um hobby. Os usuários precisavam digitar toda a linha de código em seus próprios computadores para depois desfrutá-lo, posteriormente os dados passaram a ser copiados através de fita cassetes. O Microchess, em 1976, vendeu cerca de 50 mil fitas cassetes (GOULARTE, 2010).

Em 1977, a empresa japonesa de arcades, Namco, contratou o designer Toru Iwatari, um entusiasta em jogos eletrônicos. O designer cansado de jogos espaciais e de tiro, criou um jogo para ambos os sexos chamado de Paku-paku taberu (som de fechar e abrir a boca) que mais tarde se tornou conhecido como Pac-man. Foi o primeiro personagem a sair da tela para revistas em quadrinho, desenhos animados, farmácias e livrarias. Com mais de 300 mil unidades 
vendidas em todo o mundo, Novak (2010) comenta que o Pac-man tornou-se o game mais popular de todos os tempos.

Também em 1977, é lançado o primeiro console programável com jogos variados em cartucho pela Atari. O modelo Atari 2600 passa a ser uma referência do mercado e possibilita um revigoramento do setor (1978-1983).

Em 1978, Space Invaders é considerado o arcade de maior sucesso e gerou centenas de milhões de dólares, não só para os desenvolvedores, mas também para outras empresas que imitaram a fórmula de sucesso do jogo. $\mathrm{O}$ jogo foi o primeiro a ter uma lista acumulativa com os melhores escores dos jogadores, estabelecendo um novo conceito de competição. O sucesso foi tanto que o governo japonês precisou aumentar a produção de moedas de 100 Yenes. Abrem-se as portas para o intercâmbio entre o mercado americano e japonês. Em 1979, é criada uma nova versão, chamada Galaxian, sendo o primeiro jogo colorido com o sistema RGB (Red, Green e Blue).

\section{Anos 1980}

Um passo significativo na evolução histórica dos vídeogames foi a introdução dos efeitos gráficos viabilizados pelos avanços tecnológicos na década de 1980, sendo que o primeiro jogo a apresentar tal novidade, de acordo com Marx (2007) foi Mystery House para o computador Apple II, em 1980.

Em 1981, uma pequena empresa japonesa, Nintendo, inovou com o primeiro jogo de plataforma para arcade: o personagem se movimenta lateralmente, para cima ou para baixo em um cenário bi-dimensional. Era o videogame "Donkey Kong” que vendeu mais de 60 mil máquinas de arcade e elevou a empresa a ser reconhecida mundialmente. Mais tarde, um de seus personagens vem a se tornar o famoso "Super Mario".

Aproveitando o sucesso do arcade, em 1982, a Nintendo lança uma versão de “Donkey Kong Jr.” em um pequeno console móvel com tecnologia de tela LCD, como a de uma calculadora, cabendo na palma da mão.

A Namco lança o "Pole Position" (1982) para o console Atari, uma simulação de Fórmula 1, considerado o jogo mais realista da época, em que a visão por trás do carro é utilizada até hoje nos jogos de corrida. Também são criadas versões para os arcades. 
Os jogos vetoriais como o Star Wars (1983) perderam força a partir de 1984 e praticamente pararam de ser fabricados, devido ao avanço tecnológico dos jogos rasterizados através de disc laser. Entretanto, os jogos de arcades, rodados em disc laser, não encontram consistência no mercado, porém indicam para onde a tecnologia dos games deve seguir (GOULARTE, 2010).

Em torno de 1983, as lojas ficaram abarrotadas de consoles e uma excessiva quantidade de cartuchos com diversos títulos de vídeogames (alguns provenientes dos arcades), muita concorrência e uma certa estagnação tecnológica, fizeram com que o esse mercado sofresse uma grande queda.

Em 1984, a indústria dos computadores pessoais em franco avanço tecnológico se estabelece como uma nova possibilidade de entretenimento popular. A Apple lança o Macintosh, um sistema de recursos gráficos e de áudio aprimorado e uma interface de usuário acessível e de fácil utilização. Um ano depois, a Microsoft introduz o sistema operacional Windows, tornando-se assim grandes concorrentes.

Os jogos dos arcades ainda resistem e continuam fortes o suficiente para justificar o custo da compra de fichas para se jogar apenas três minutos por partida. Buscam novos nichos de mercado, como em grandes lojas ou centros de recreação em shopping centers. Os arcades crescem, agregando à sua estrutura, poltronas de piloto de Fórmula 1, pistolas, e seus monitores ficam maiores.

Enquanto o Brasil era semeado pelos consoles da Atari, nos EUA em 1985 a Nintendo lançava o que viria a ser a nova referência dos consoles de 8-bits, que chegou à surpreendente marca de 62 milhões de unidades em toda a sua existência. Com uma qualidade gráfica próxima dos computadores e arcades, ainda em cartuchos que posteriormente passaram a ser substituídos por CDs, novo controle remoto (8 comandos), além de músicas temáticas, efeitos sonoros, design sofisticado de personagens e um bom roteiro fizeram de Super Mario Bros, um jogo de sucesso (GOULARTE, 2010).

Por outro lado, o console Atari 7800 vende apenas 1milhão de unidades e com deficiências técnicas entra em decadência.

Em 1988, a Sega lançava seu console concorrente, Genesis, de 16-bits e rodado a partir de cartuchos, que ganha popularidade sobre a Nintendo. Entretanto, um ano depois, a Nintendo inaugura a nova era dos portáteis com o Game Boy, inicialmente com tela monocromática, de acordo com Novak (2010), a empresa vem a lançar novas versões desse produto ao longo dos próximos anos. 
No final da década de 1980, SimCity (EA Games, Maxis, 1989), para computadores pessoais, destacou-se como um dos primeiros games de simulação a fazer sucesso. Tal novidade abriu um novo e vasto campo de entretenimento em que o jogador tornava-se apto a construir uma cidade qualquer e da maneira como desejasse, gerenciando recursos, determinando divisões territoriais, impostos etc. SimCity simulava os resultados dessas manipulações e as reações dos habitantes virtuais (MARX, 2007).

\section{Anos 1990}

Os games designers ganham destaque e se mostram capazes de recriar um produto com uma dinâmica que favoreça a novos tipos de experiência, como foi o caso do Street Fighter II, em 1991, cuja versão original não fez sucesso algum, contudo, com uma remodelada composição gráfica bem acabada e estimulante, e jogabilidade aprimorada, o game ditou o novo rumo para os arcades ao longo dessa década.

No Brasil, nascia o mercado de locadora de console e seus cartuchos, que atraiam filas de jogadores para jogar nos consoles Mega Drive e Super Nintendo. As locadoras tornaram-se pontos de encontro entre jogadores.

Perdendo espaço para a Sega com o seu Mega Drive no mercado de consoles, a Nintendo acelera o desenvolvimento e lançamento do Super Nintendo para 1990. Com gráficos e sons ainda melhores, com 32-bits, vende 49 milhões de unidades, contra 29 milhões da concorrente.

A Sega cria o personagem de um porco-espinho, o Sonic, com um dinamismo e ação jamais vistos, com obstáculos e muitos níveis, além de uma nova proposta de controle remoto em forma de meia lua e botões mais ergonômicos.

Com o surgimento das Lan-houses e a possível escolha dos jogadores para jogarem dentro de casa seus games prediletos por meio de consoles, isso ocasionou um grande declínio nos arcades encontrados em estabelecimentos comerciais.

Ao longo dessa década, avanços significativos dos computadores em sua capacidade gráfica, velocidade de processamento, recursos de áudio e, principalmente, a conexão em rede, novas versões dos games como o Doom , Quake e Diablo desencadearam uma nova tendência social entre os usuários. 
Mais uma vez, o mundo vivenciava uma revolução na condução do mercado de games. Constituiu-se um mercado de entretenimento de games com arcades, consoles, portáteis e computadores com uma forte tendência a convergência tecnológica que, aos poucos, vão incorporar o DVD, a internet e a telefonia celular.

Em pouco tempo, as empresas que produziam os games se transformaram em sofisticados estúdios de criação com grandes equipes de profissionais e com tarefas bem variadas e específicas como os game designers, designer de níveis, ilustradores, animadores, roteiristas, sonoplastas entre outros. Esses desenvolvedores garantiam seus direitos sobre a marca e a imagem do game como modelo de negócio, pois o público consumia os mais variados produtos através da franquia, de roupas, desenhos animados, brinquedos e guloseimas.

Para Novak (2010), o ingresso do Playstation da Sony no mercado de consoles em 1995 deu início a um novo capítulo na disputa por esse segmento, como o console de última geração com a incrível marca de 100 milhões de unidades vendidas, contra 32 milhões do Nintendo 64, apesar de sua tecnologia de 64-bits.

Os games vão se sofisticando, tanto para seu uso em consoles ou computadores. O Ultima Online (UO) é um dos primeiros MMORPGs (Massive Multiplayer On-Line Role Play Games) lançados comercialmente em 30 de setembro de 1997 pela Origin Systems. Esse título vai se estabelecer como um dos três MMORPGs mais jogados no mundo. O game é situado num universo de um cenário medieval (NOVAK, 2010).

Com a popularização da telefonia celular, os aparelhos passaram a oferecer games, propiciando entretenimento além da função original do equipamento. Em 1995, era possível encontrar versões do game “Tetris” nas telas monocromáticas dos celulares e um pouco depois, em 1997, já podíamos jogar o game "Snake”.

\section{Anos 2000}

Os games para computadores demandam melhores placas gráficas para processar informações de vídeo para os games e a Nvidia inicia a venda das placas Gforce. Apesar de games como Warcraft, Comand and Conquer, Diablo, Starcraft funcionarem bem, essa geração de games passa a ser conhecida como o 
início da decadência do 2D. São lançados grandes sucessos de games MMOs (massive multi-players on-line) como Quake II e Counter Strike, esse gênero ganha força em que os títulos de consoles se misturam com os de PCs nas lojas. Para Goularte (2010), os jogadores em geral passam a avaliar se é melhor ter um console ou um computador para jogos.

A Sega é a primeira a lançar o novo console com 128-bits, com conexão para internet via modem acoplado, entrada para teclado, navegador para acessar internet e resolução maior do que qualquer outro videogame até o momento. Entretanto, acabou sucumbindo ao império da Sony por não conseguir recursos para novas pesquisas tecnológicas para as próximas novidades.

Em 2000, Sony se supera com o lançamento do Playstation 2 e vende ao longo dos próximos anos, mais de 100 milhões de unidades em todo o mundo. $\mathrm{Na}$ disputa por esse segmento entram o Game Cube da Nintendo, mais voltado para o público infantil e pré-adolescente, e o Xbox da Microsoft, para um público jovem e adulto.

A busca dos usuários por novas experiências, segundo Goularte (2010), fez com que games como Halo, Guitar Hero, God of War, Sonic Adventure entre outros, oferecessem novos níveis de interatividade ou sociabilização com outros usuários pela internet.

Nem consoles ou computadores, as empresas de telecomunicações avançam em busca de uma surpreendente convergência. Por meio de experiência on-line ou local e o desenvolvimento de aplicativos para as plataformas de celulares, empresas como a Nokia, Sony, Panasonic e Samsung apresentavam simples games de entretenimento em seus equipamentos. Entre tantas tentativas, em 2003, a Nokia lança o N-Gage, um híbrido de celular e console portátil que fracassa por não combinar bem, ambas as funções de modo eficiente.

Em 2004, a Nintendo lança o console móvel Nintendo DS com vários títulos de games, conquista o público infantil e consegue a incrível marca de vendas no ano de 6,6 milhões de unidades em todo o mundo.

Dois anos depois a Nintendo, mantendo o seu perfil de se diferenciar por não criar somente os vídeogames, mas centrais de lazer para todas as idades, lança o Nintendo Wii. De acordo com Adams (2003), um console não muito poderoso, mas com controles remotos simplificados que possuíam sensores de movimento, permitindo ao jogador simular o movimento da ação à frente do 
televisor. A proposta era atingir além do público infantil, não-jogadores como pais e avós. E conseguiram! Venderam 56 milhões de aparelhos, superando o Xbox 360 com 31 milhões e o Playstation 3 que teve 27 milhões (GOULARTE, 2010). A Nintendo criou mais de 50 tipos de acessórios, como tacos de golfe, espada, pistola, raquete, volante, balança entre outros.

No início de 2007, Steve Jobs, CEO da Apple, anuncia o lançamento de um smartphone, que vai revolucionar tanto a telefonia móvel como muitos outros serviços digitais, incluindo o mercado de games. O iPhone vem com funções de gerenciador de músicas, câmara digital, internet, mensagens de texto (SMS) e conexão wi-fi local. A interação com o usuário é feita através de uma tela sensível ao toque e com um sistema operacional que permite que desenvolvedores criem milhares de programas adicionais.

Assim, os smartphones passam a ser utilizados como consoles portáteis de games pelas ruas, enquanto se desenrola uma batalha entre os fabricantes de consoles tradicionais de games para o armazenamento dos jogos, o conflito se dá entre o HD-DVD e o Blu-Ray, que só vai terminar em 2008, com a vitória da Sony com o seu Blu-Ray, propiciando aos usuários do Playstation 3 experimentar games com melhor qualidade e desempenho.

Ao longo dos anos 2000, criam-se jogos on-line gratuitos, de mini-games a games complexos, que se multiplicam geometricamente e começam a ser organizados em portais na internet como o FRIV, Kongragate e Os Jogos.

Além disso, surge em 2004, a rede social Orkut, criada por um engenheiro turco Orkut Buyukkokten, funcionário da Google, inicialmente para fomentar a interação social entre seus usuários, que mais tarde ficou disponível para games individuais ou coletivos, chegando à marca de 33 milhões de usuários no mundo. Entretanto, um mês depois de seu lançamento, surge a rede social que vem a ser a sua grande concorrente e fará minguar os seus futuros projetos. Vindo dos campos universitários americanos, o “Facebook”, desenvolvido por Mark Zukerberg, apresenta uma interface mais moderna, com mais ferramentas e mais intuitiva que, aos poucos chega ao fim de 2012, a 1 bilhão de usuários ativos.

No início de 2009, é lançado o game social “FarmVille”, um simulador de uma fazenda em tempo real, desenvolvido pela produtora Zynga. Embora seu acesso só pudesse ser feito pelo website da própria produtora, seu grande sucesso deu-se no momento em que foi disponibilizado como um aplicativo da rede 
social Facebook chegando à marca de quase 64 milhões de usuários ativos ao final do mesmo ano de seu lançamento.

Idealizado pelo programador sueco Mark Persson, e lançado em meados de 2009, o "Minecraft” se tornou, em pouco tempo, o jogo para PC mais vendido de todos os tempos, atrás apenas de “The Sims 2”. E deve crescer ainda mais, porque, a cada dia, cerca de 15 mil usuários baixam o game (O GLOBO, 2013). Com o sucesso e um grande aparato tecnológico, o game também passou a ser jogado no tablet ou no smartphone. E além disso, em seu processo de convergência, surgem jogadores como o curitibano Bruno Aiub, mais conhecido como Monark, que tem um canal no YouTube sobre o "Minecraft”, no qual um único vídeo sobre a Caverna do Dragão que está registrado mais de 2,4 milhões de visualizações (MONARK, 2012).

\section{Anos 2010}

Em meio a tantos avanços tecnológicos, surgem novos acessórios como o Kinect, para o Xbox360 da Microsoft, lançado no final de 2010, apresentando uma nova tecnologia capaz de permitir aos jogadores interagir com os games sem a necessidade de ter em mãos um controle remoto, inovando no campo da jogabilidade, superando as novidades trazidas, até o momento, pelo console Wii, da Nintendo. O Kinect é apresentado como equipamento para o entretenimento, porém, tem sido muito utilizado em ambientes de aprendizado público, como museus, além de estar sendo desenvolvido projetos para portadores de necessidades especiais.

Dois dias depois do lançamento do Kinect, se iniciou a comercialização do tablet da Apple, o iPad, depois de duas tentativas frustradas como o tablet da Grid Systems em 1989 e da HP em 2001. Foi apresentado como um dispositivo situado a meio caminho entre o seu modelo de laptop "MacBook" e o de celular "iPhone”, que inspirado no sucesso dos Smartphones, utilizava a tecnologia de tela sensível ao toque dos dedos, dispensando canetas especiais como os antecessores fracassados. Foi um marco na história da tecnologia de informação, pois mostrou ao mundo as inúmeras possibilidades em que tais dispositivos poderiam ser úteis. O preço dos tablets atrai os consumidores e impacta a comercialização de PCs e principalmente de notebooks.

Com o lançamento da plataforma Windows 8 da Microsoft, em 2011, fica evidente o processo de convergência entre as tecnologias, pois essa plataforma é 
utilizada desde o computador pessoal (desktop ou móvel), nos smartphones e também no seu console Xbox.

Os smartphones, por sua flexibilidade, estão no centro de todas as conexões entre os produtos eletrônicos. Segundo Ana Pereti, diretora de marketing da Sony Mobile Brasil, o mercado de smartphones é o que mais cresce no Brasil e que vendeu 19 milhões de unidades em 2012. Além da Sony, a Microsoft tem investido nesse segmento.

Ainda com ascensão dos notebooks sobre os computadores, os hardwares vêm se adaptado às demandas dos usuários, inclusive para games, com produtos um pouco menores e bem mais leves, o que deve favorecer cada vez mais aos tablets. Hoje, já é possível comprar um aparelho portátil capaz de substituir o desktop, que, para Goularte (2010) está com os seus dias contados. Os games e seus programas estão cada dia mais compactos, pois não adianta fazer o melhor hardware se o software não puder usar bem os recursos oferecidos.

Após décadas de desenvolvimento, os segmentos da indústria de games estão cada vez mais semelhantes em nível tecnológico. Os consoles e os computadores convergem, impulsionados por uma evolução rápida e inesperada de games on-line, seja por meio da conexão à internet, seja pela tecnologia de telefonia celular, além de incorporarem a tecnologia de DVD (NOVAK, 2010). A conexão à internet além de propiciar a interconexão entre os jogadores, possibilita a compra on-line de games e filmes.

Com isso, a indústria de games, em 2012, passou a ser uma das mais prósperas do planeta, faturando mais de US\$60 bilhões, segundo consultorias como Gartner e DFC Intelligence. O Brasil se tornou o quarto país com jogadores ativos ligados a web, com 35 milhões de usuários. Nesse mercado bilionário há uma grande diversidade de indivíduos que contribuem para o seu crescimento, como: estúdios, desenvolvedores, distribuidoras, fabricantes de plataformas de hardware e, naturalmente, os jogadores-consumidores (O GLOBO, 11/12/2012).

Em setembro de 2013, o "Grand Theft Auto V” chegou às lojas dando mostras das dimensões dessa indústria. O jogo, que custou US\$ 250 milhões para ser produzido, bateu seis recordes mundiais, incluindo o de produto de entretenimento com maior faturamento em 24 horas (US\$ 800 milhões) e que primeiro atingiu US\$ 1 bilhão em vendas (3 dias). “Avatar”, o filme de maior sucesso da história do cinema, levou 19 dias para arrecadar a mesma quantia. E 
Nolan Bushnell diz que quando fundou a Atari, sabia que o mercado seria grande, mas não imaginava que um dia superaria o cinema.

Um desses recordes é superado quatro meses depois, pois o game "Black Ops” lança sua nova versão “GHOST” e fatura US\$1 bilhão no primeiro dia de vendas para os lojistas (O GLOBO, 07/11/2013). Enfim, não chegamos nem na metade dessa década, e em um espaço de apenas três anos foi possível experimentar tantas novidades. Qual será a tendência do mercado de games para os próximos anos?

No número global de vendas, 2012-2016, o mercado de games deve crescer em todos os segmentos, saltando dos US\$66 bilhões para US\$ 86 bilhões, segundo a Newzoo (Centro Internacional de Pesquisa de Jogadores de Games). No infográfico a seguir (Figura 2), pode se analisar os indicativos de crescimento ou redução na participação do equipamento no mercado de games ao longo desse período e a proporção de usuários que utilizam cada um desses produtos/serviços. Há indicativos para um avanço no uso de smartphones e tablets sobre os consoles portáteis e os computadores.

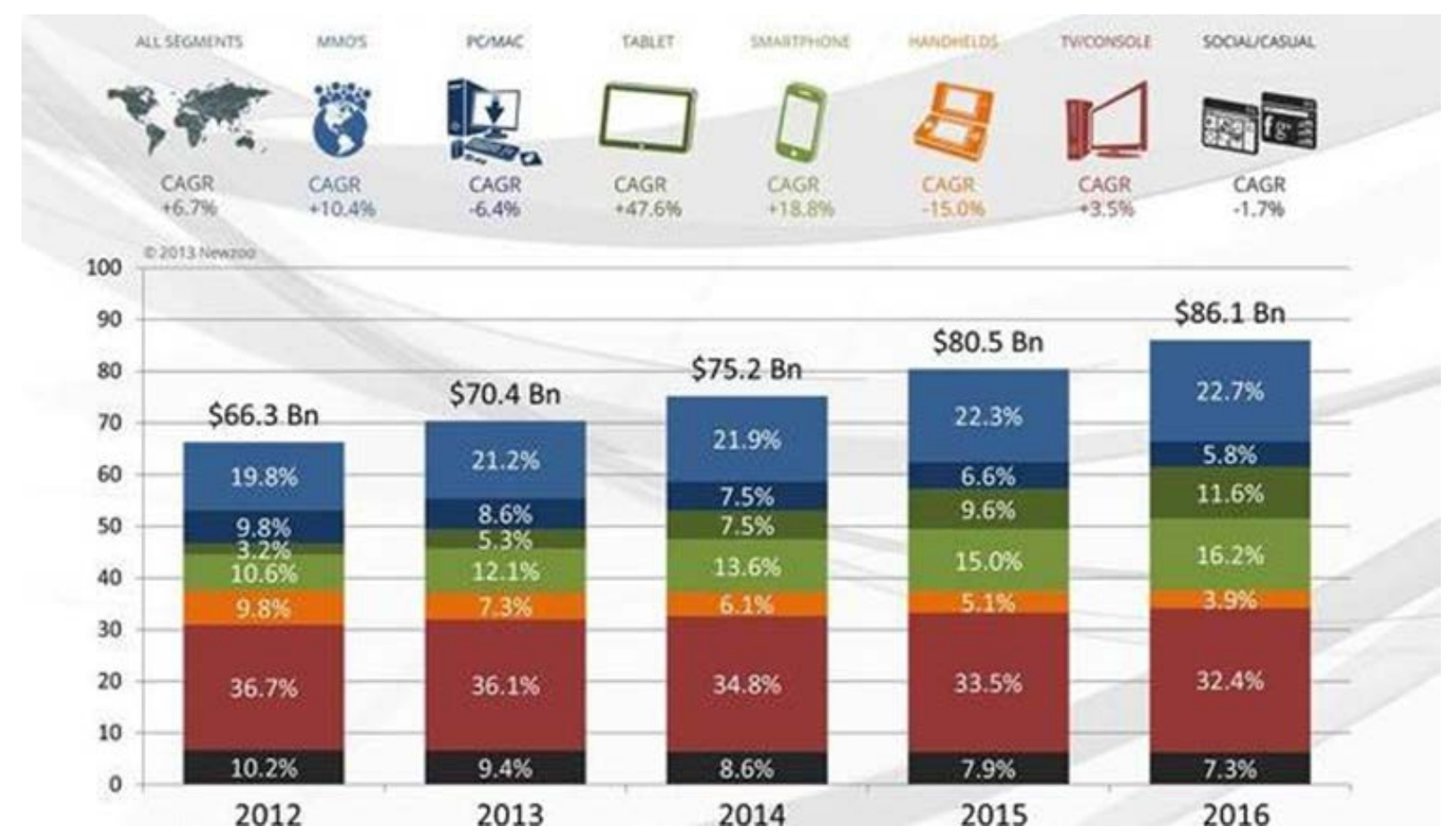

Quadro 1. Levantamento do mercado mundial de games de 2012 até 2016 Fonte: Newzoo 
Mesmo com a previsão de uma pequena queda do mercado de consoles, esse ainda será um segmento de grande faturamento da indústria, juntamente com o mercado de games com multijogadores (MMOs).

A tendência pela expansão dos dispositivos móveis, como os tablets e smartphones, em detrimento da diminuição de usuários de PCs e consoles, deve continuar devido à praticidade de portabilidade desses equipamentos e sua contínua queda de preços. Esse fato tem propiciado para as crianças e jovens a criação de novos hábitos e até mesmo códigos de linguagem.

\section{1}

\section{Conceituação: o game estabelece um nova cultura mundial}

Os games, de maneira geral, correspondem a um fenômeno contemporâneo que necessita ser estudado e compreendido pelos impactos positivos que apresentam. Para Gallo (2007), parte de sua dimensão cultural abrange não apenas um potencial expressivo social como, também, educacional.

A tecnologia da informação e comunicação caracteriza-se como uma nova tecnologia intelectual, que nos permite potencializar não apenas nossa memória, mas também diferentes formas de raciocínio. Tanto para Mattar (2010) como para Levy (2000), as transformações tecnológicas que se proliferam estão criando uma nova cultura, que está revolucionando a nossa maneira de interagir com os objetos, as informações, as pessoas, o meio ambiente e o mundo.

cultura [Lat. cultura] sf. O complexo dos padrões de comportamento, das crenças, das instituições, das manifestações artísticas, intelectuais etc., transmitidos coletivamente.

Fonte: Dicionário Aurélio

Segundo Jenkins (2006), jornalista americano e pesquisador de mídias, a expressão cultura participativa contrasta com as noções mais antigas sobre a passividade dos espectadores dos meios de comunicação. Ao invés de colocarmos os produtores e consumidores de mídia com distintas atribuições, os consumidores têm assumido um novo papel, como uma espécie de co-produtores e até mesmo coautores. Essa dinâmica é viabilizada pela possibilidade de uma real interatividade do produto com o usuário, e do usuário com outros usuários, o que faz com que mais pessoas se interessem e sigam determinadas regras para que o sistema, 
qualquer que seja, funcione de forma eficiente e contínua. Assim , o universo digital envolve cada vez mais adeptos.

100 milhões de horas ativas na internet: tempo de construção do conhecimento da Wikipedia $=3$ semanas de horas jogadas no Angry Birds $=7$ dias jogados no Call of Duty. Fonte: Gallup, 2013

Goularte (2010), comenta que nesse processo, formou-se uma cultura dos games caseiros coletivos, fazendo com que crianças e jovens se reunissem no salão de festas do seu prédio para jogar por horas com seus colegas.

Segundo o Instituto de Pesquisas Americano Gallup, foi contabilizado no final do ano de 2013, que há 1 bilhão de jogadores ativos no mundo e que, também, 92\% das crianças americanas com até 2 anos de idade jogam games. Esse processo de engajamento com as mídias e os games é reforçado pelo depoimento de Camargo:

\footnotetext{
"Antigamente usava-se o celular focado em produtividade, trabalho. Hoje ele se consolida como uma plataforma de entretenimento e os games foram fundamentais para essa expansão" afirma Guilherme Camargo, professor do curso de Game Marketing da ESPM-SP e sócio-CEO da Sioux (ADNEWS, 2013).
}

Porém, a relação dos usuários com as mídias interativas vai além da necessidade em adquirir conhecimento, mas de criar experiências. Por sua vez, essas experiências têm gerado novos paradigmas e o universo digital nos proporciona constantes descobertas que vão muito além da linearidade dos livros e do audiovisual. Para Bonsiepe (1997), designer e acadêmico canadense, são tamanhas as transformações tecnológicas e suas consequências sociais, éticas, culturais, interação e experiência.

Incluindo nesse processo o advento da globalização, que ocasionou a utilização de ferramentas e produtos digitais que cruzaram fronteiras e são amplamente utilizados em todo o mundo, com isso, se desenvolveram códigos de comunicação à parte do idioma local. Expressões de comando da funcionalidade de games na língua inglesa têm sido adaptadas e regionalizadas criando uma nova linguagem entre os jogadores, como deletar (delete), farmar (farming), upar (leveling up) e tantos mais . Além dos personagens ou ícones dos games que são reconhecidos e compreendidos por todos os usuários. Essa linguagem simplista e icônica constitui-se como uma cultura visual, e como explica Mirsoeff (2003), há interesse pelos acontecimentos visuais em que o consumidor procura informação e significado, ou lazer, conectado a uma tecnologia visual. A função principal da 
cultura visual é dar sentido à realidade infinita de uma realidade exterior mediante a seleção, interpretação e representação da dita realidade.

Por isso, Jenkins (2006) comenta que a convergência não corre, simplesmente, por meio de aparelhos, por mais sofisticados que venham a ser. O autor comenta que a convergência se dá dentro dos cérebros dos consumidores individuais e em suas interações sociais com os outros. O consumo, por sua vez, tornou-se um processo coletivo e é isso que o pesquisador americano entende por inteligência coletiva, expressão cunhada pelo ciberteórico francês Pierre Lévy (2000). As mudanças que ocorrem na organização e na produção de conhecimento criam a base de uma nova sociedade, na qual o saber passa a ser entendido como o produto de negociações coletivas que envolvem pessoas e artefatos tecnológicos.

\section{O que os games têm de diferente que os destacam de outras atividades de entretenimento?}

Afinal, o que o game têm que outras atividades dinâmicas ou lúdicas não têm? Por que tipo de experiência passamos ao jogar um game que difere de outras atividades? O pesquisador americano em ludosofia e game designer, Chris Crawford (1986), fazendo uso de um organograma (Diagrama 2), nos apresenta uma possível explicação pelo o que nos faz desejarmos jogar mais uma vez.

Crawford construiu um organograma a partir da expressão criativa. Se for produzida simplesmente para ser bela e interessante, então é arte. Se for pago com dinheiro, é entretenimento. Esse entretenimento não é interativo, caso seja um livro, filme ou semelhante, é interativo. Brincadeiras podem não ter metas, nesse caso são brinquedos, ou se tiverem metas, tornam-se desafios. Um desafio sem um competidor é um quebra-cabeça, já um desafio com competidor gera um conflito/disputa. Se essa disputa não permite um ataque real, então é uma competição, se permitir, então é um game. 


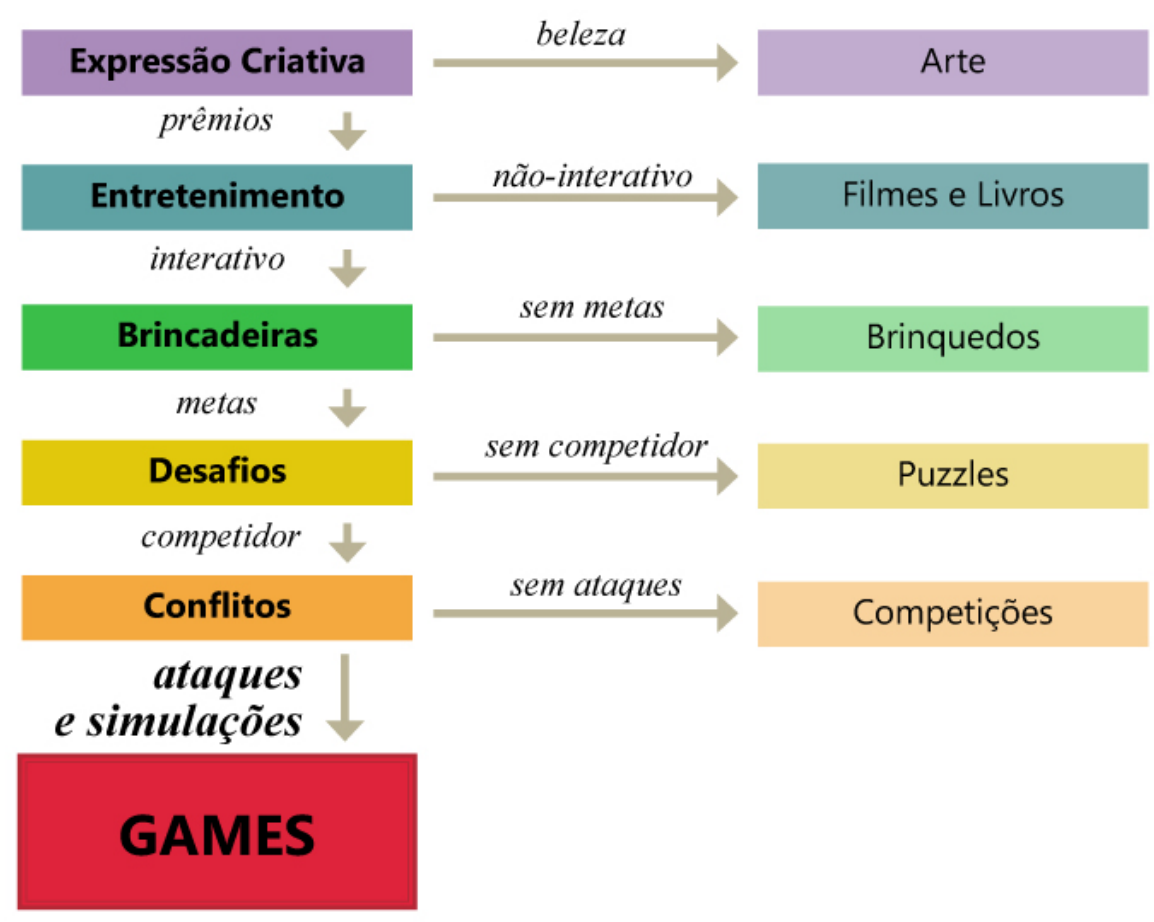

Diagrama 2. Fluxograma da expressão criativa ao game Fonte: Chris Crowford (1984)

Em outras palavras, nessa taxonomia, um game é uma expressão criativa que se faz dinheiro, é interativa, tem metas, tem competidores e permite ataques reais.

O que esses quatro games tão distintos SimCity, Angry Birds, Wii Bowling, e Call of Duty têm em comum? É que todos são simulações, respectivamente, uma cidade em construção, pássaros que são arremessados, bolas de boliche jogadas e soldados que atiram para matar. Portanto, a simulação é uma possibilidade nos games que, além de atuar de forma graficamente realista, oferece meios para que o usuário interfira na ação, porém, sem colocar a sua integridade física em risco.

Além da possibilidade da simulação virtual, Prensky (2010, p.85), em seu livro “Aprendizagem baseada em jogos digitais” sugere várias outras razões pelas quais as pessoas preferem os games, ao invés de outras atividades de entretenimento, pois:

- Os games costumam ser mais rápidos e apresentam mais reações;

- Os games podem ser jogados contra pessoas reais, e se não houver nenhuma disponível, contra a inteligência artificial, ou seja, o próprio computador; 
- O mundo inteiro (isto é, qualquer um que estiver on-line) está disponível como possível jogador;

- Os games podem ser jogados em níveis diferentes de desafio;

- Os games conseguem mais e melhores representações gráficas (imagens, cenários e animações);

- Os games podem ser atualizados quase que instantaneamente;

- Os games podem ser personalizados para atender ao gosto e a vontade de cada jogador;

- Os games podem lidar com um número infinito de conteúdo.

Nesse contexto, o universo dos games, produto das tecnologias de informação e comunicação das últimas décadas, nos disponibiliza uma possibilidade virtual e agilidade em processos que envolvem conteúdo, que até a pouco inexistia. Temos um potencial pela frente em relação ao entretenimento e a educação ofertado por esse campo de inovação.

\section{2}

\section{Tecnologia em prol dos games}

Em meados da década de 1970, a indústria de games com seus arcades e fliperamas, juntamente com outro segmento, entraram em uma nova era. A revolução do computador pessoal trouxe para o lar uma tecnologia que, de acordo com Novak (2010, p.24), até então, era um território exclusivo de programadores e aficionados. As versões de jogos de fliperamas e passatempos começaram a ser transportados para sistemas de videogames domésticos com suas plataformas inovadoras, roubando parte do mercado das casas de games eletrônicos.

A plataforma corresponde à estrutura ou componente operacional que suporta a ação manipulativa do usuário frente ao sistema do jogo (XAVIER, 2007; MARX, 2007). Na proposta de Xavier os games são organizados por sua apresentação manipulativa, ou seja, pelo tipo de plataforma (hardware) que suporta a ação do game e como ele se apresenta (software). A seguir: 


\section{O hardware}

Pode ser definido como um termo geral da língua inglesa que se refere a equipamentos como ferramentas, utensílios e peças de máquinas. No âmbito eletrônico o termo "hardware" é bastante utilizado, principalmente na área de computação, e se aplica ao tipo de plataforma, ou seja, à unidade central de processamento, à memória e aos dispositivos de entrada e saída (GALVIN, 2008).

Arcade ou fliperama (como é tradicionalmente conhecido no Brasil) é um equipamento com um jogo eletrônico e encontrado em estabelecimentos de entretenimento públicos. Entretanto, com a evolução da tecnologia os jogadores brasileiros passaram a usar outras três distintas plataformas para jogar (Figura 3), segundo a pesquisa Game Mobile Brasil, realizada pela ESPM, Sioux e Blend New Research, em 2013.

O PC ainda é o mais utilizado, com 85\%. Mas os aparelhos celulares representam $73 \%$, acima dos consoles, com $66 \%$, e dos tablets, com $31 \%$. O principal motivo seria, além da mobilidade, a grande oferta de games para esta plataforma.

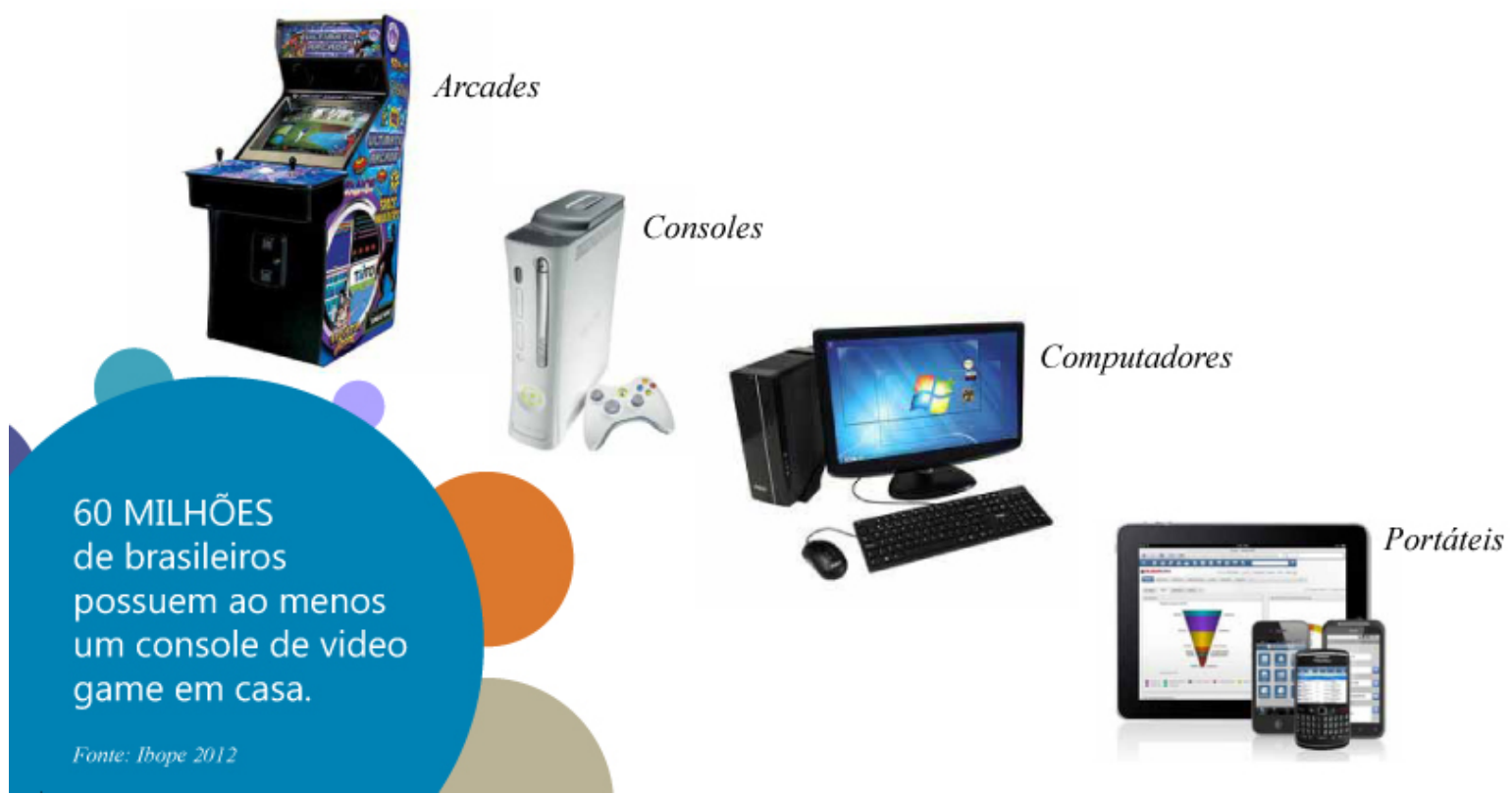

Diagrama 3. Equipamentos para se jogar games

Fonte: $\mathrm{O}$ autor

"Antigamente usava-se o celular focado em produtividade, trabalho. Hoje ele se consolida como uma plataforma de entretenimento e os games foram fundamentais para essa expansão" afirma Guilherme Camargo, professor do curso de Game Marketing da ESPM-SP e sócio-CEO da Sioux (ADNEWS, 2013). 
Os fabricantes de celulares (smartphones) e tablets desenvolveram distintos sistemas operacionais para dispositivos móveis com tela sensível ao toque. Os mais populares são o Android (Google), IOS (Apple) e o Windows (Microsoft). Cada equipamento funciona com um único tipo de sistema operacional e os games precisam ser desenvolvidos em diferentes versões, de forma que sejam compatíveis com cada sistema.

Entre os sistemas operacionais, o Android ainda domina o mercado, em $70 \%$ dos celulares e $71 \%$ dos tablets. Nos tablets, em função do sucesso do iPad, a plataforma iOS está em segundo lugar, com 18\%, mas nos celulares fica em terceiro, com 6\%, atrás do Windows , com 9\%.

\section{Arcades}

Para fins comerciais, aqui no Brasil, são também conhecidos como fliperamas, ao dividir os ambientes de lazer com os fliperamas mecânicos dos anos 1950 e suas bolas de aço. Assim como os fliperamas são produzidos em máquinas eletromecânicas operadas por moedas. Neste tipo de plataforma as máquinas são compostas por uma tela presa a um gabinete, um painel de botões ou outros tipos de controle para se jogar o game. O gabinete é decorado com o tema do game e o jogador costuma ficar em pé ou, no caso de simuladores, fica sentado em uma cadeira similar ao veículo que está jogando. O tempo de cada game é limitado ao número de rodadas que a moeda permite.

Os arcades são encontrados em locais públicos, como lojas de jogos eletrônicos e, geralmente, visam o entretenimento sem conotação educativa, como games de luta, tiro, corrida ou jogo de azar.

\section{Consoles}

Desenvolvidos para ambientes domésticos os equipamentos são ligados a controladores manuais, que se conectam a um televisor ou monitor. Os consoles possuem um sistema próprio de programação de dados que pode ser ou não compatível com outros tipos de plataforma (XAVIER, 2007). Podem ser conectados a internet e usados para navegar na web. Alguns exemplos são Wii, Xbox ou PlayStation.

Há também modelos de consoles portáteis para o público infantil como o pequeno Nintendo DS. 


\section{Computadores}

Dispositivo eletrônico com capacidade para processamento de dados e que pode ser de mesa ou manual (laptop). Os computadores podem apresentar sistemas operacionais de fabricantes diversos como Microsoft, Apple ou Linux. Este tipo de equipamento é recomendado para games que exigem uma alta performance de hardware.

\section{Dispositivos móveis}

São dispositivos portáteis como celulares, tablets entre outros. Nesse tipo de equipamento, a interação com o usuário é feita através de uma tela sensível ao toque e com um sistema operacional que permite que desenvolvedores criem games com extrema simplicidade e eficiência.

\footnotetext{
"O mercado de celulares é mais próximo, em certos aspectos, ao mercado de games on-line leves (games de quebra-cabeças e clássicos de tabuleiros e cartas) do que do mercado convencional para consoles e desktops. As pessoas usam games em celulares para se divertir e passar o tempo, não para uma experiência intensa de jogo.” (Greg Costikyan, diretor-presidente da Manifesto Games, 2000)
}

Com a evolução dos celulares, os consoles portáteis como o Game Boy, PSP da Sony e Nintendo DS estão caindo em desuso. Além disso, os equipamentos das TICs avançam em busca de uma surpreendente convergência. Por meio de experiência on-line ou local, o desenvolvimento de aplicativos para as plataformas, tem possibilitado se jogar, até os games mais complexos ligados a redes sociais ou com multijogadores.

Nas redes de ensino, existe uma forte tendência ao uso de tablets com diversas aplicações de objetos digitais de aprendizado, como games educativos.

\section{Sensores de movimento}

Equipamentos que se utilizam com consoles, eles se destacam pelo seu controle sem fios, dotado de um acelerômetro capaz de detectar movimentos em três dimensões. Entretanto, novas tecnologias estão permitindo aos jogadores interagir com os games sem a necessidade de ter em mãos o controle remoto, inovando no campo da jogabilidade (NOVAK, 2010). Com um detector de movimentos preciso, ele identifica gestos sutis como o mover os dedos, o girar do pulso ou mesmo suas expressões faciais e até identificar seu batimento cardíaco. Além de oferecer uma experiência diferente aos jogadores de games, os sensores 
de movimento oferecem um grande potencial de uso à educação, tanto em exposições e experimentações virtuais como, também, para atividades com pessoas portadoras de necessidades especiais.

Os sensores de movimento não se tornaram populares pelo seu custo e por demandarem uma área livre para seu uso (1,8 metros livres entre o sensor e os jogadores), porém é cada vez mais comum o encontrarmos em exposições educativas ou artísticas, por sua extrema interatividade.

\section{O software}

Software, na língua inglesa, é um termo utilizado para suporte lógico, ou seja, uma sequência de instruções a serem executadas, na manipulação, redirecionamento ou modificação de um dado, informação ou acontecimento. "Software" também é o nome dado ao comportamento exibido por essa sequência de instruções quando executada em um computador ou máquina semelhante (FERNANDES, 2006).

\section{Softwares de produção}

São ferramentas para o desenvolvimento dos games. Os profissionais da produção de games necessitam de ferramentas sempre atualizadas para renovar a qualidade e experiência dos games. Através dos softwares de produção podem-se criar elementos gráficos, de animação, de texto e de interatividade.

Pelo advento da convergência de tecnologias e novos softwares, permitiuse a comunicação massiva entre usuários de games. Os mais utilizados são: Photoshop (ilustração), Flash (animação 2D), Unity 3D (animação 3D) e Java/C++ (banco de dados), apresentados na Figura 5, a seguir.
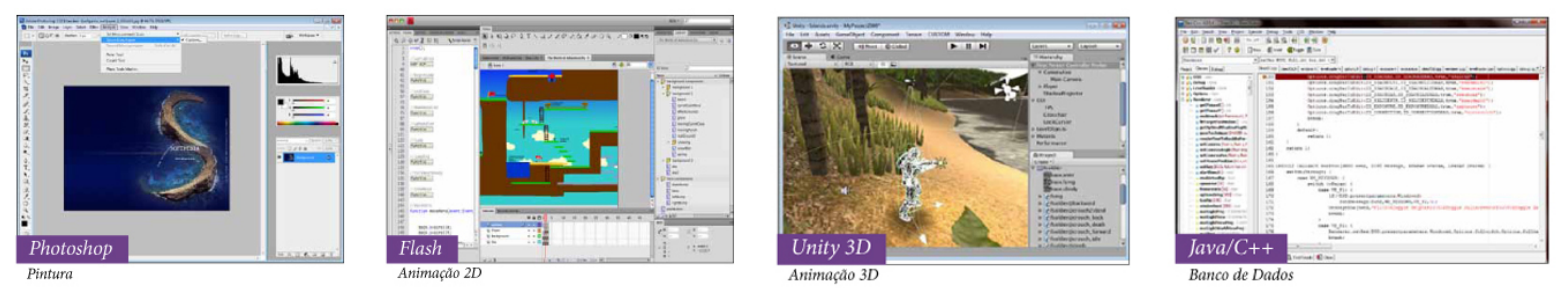

Diagrama 4. Softwares utilizados para o desenvolvimento de games

Fonte: $\mathrm{O}$ autor 


\section{Redes sociais}

Têm adquirido importância crescente na sociedade moderna. São caracterizadas primariamente pela auto geração de seu conteúdo e sua descentralização (PORTUGAL, 2012). A comunicação interativa e compartilhada possibilita ao usuário gerar conteúdos (Figura 5), integrando todas as formas de comunicação, seja oral, textual, visual e sonora. De forma que, cada vez mais, possam transformar dados em conhecimento. Vários sistemas digitais têm se aprimorado na comunicação entre usuários e alguns games têm tirado proveito dessa possibilidade. Como por exemplo: Farm Ville (Zynga, 2009) e Candy Crush (King, 2012).
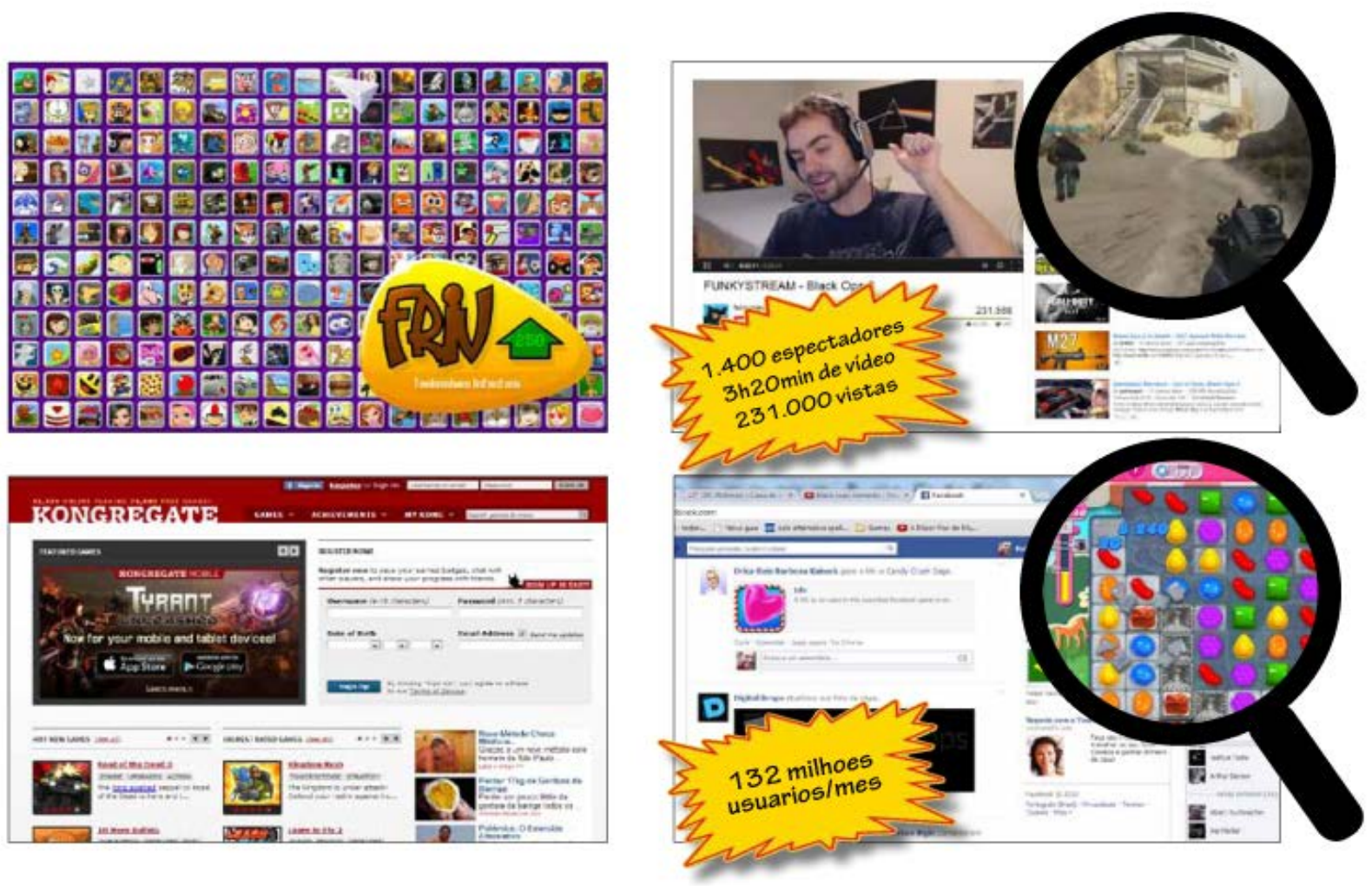

Fonte: $\mathrm{O}$ autor

\section{Portal}

É um local central para disponibilizar todos os tipos de informações a um público variado. Os portais podem ser divididos em dois tipos: o portal de informações e notícias e o portal de gerenciamento de conteúdo. Quanto aos games, são organizados em portais de gerenciamento de conteúdo e se destinam à melhorar o acesso e o compartilhamento dos games. Alguns portais são constituídos de games para serem jogados on-line e outros para serem carregados no computador. Ex.: Os Jogos (Spil Games, 2004) e Kongregate (Game Stop Network, 2006 


\section{3 \\ Classificação dos games: segundo sua função, seus componentes e profissionais de equipe}

\section{Principais segmentos de games}

Considerando o game, como produto de design e, portanto, dotado de funcionalidades, observa-se, por exemplo, que um game de entretenimento proporciona ao usuário um momento de lazer e envolvimento com a ação vivenciada durante as partidas. Por outro lado, um game educativo promove de forma clara o aprendizado de um conceito específico relacionado a algum conteúdo pedagógico, o desenvolvimento de certa habilidade ou, ainda, simula uma situação real que enfoca um contexto didático (PRENSKY, 2002). A partir desta lógica, a presente pesquisa propõe uma classificação funcional nos moldes de Aguiar (2010), apresentando alguns de seus segmentos:

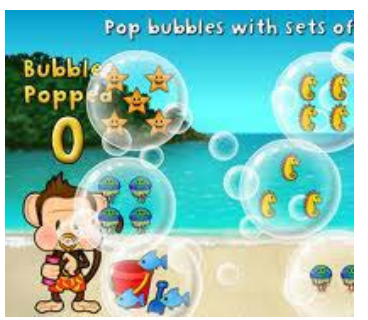

Figura 1.

Monkey Bubbles

\section{Games Educativos}

Em sua maioria, são criados para ensinar enquanto distraem. Esse tipo de game inicialmente foi desenvolvido somente para o público infantil, entretanto a demanda para estudantes maiores tem aumentado nos últimos tempos. Embora a educação formal seja a meta específica para a aplicação desse tipo de game, alguns games de entretenimento também são utilizados por docentes, devido a alguma particularidade que propicie o ensino de alguma área de conhecimento. Todo game educativo apresenta alguma aderência ao currículo escolar.

Os games educativos que apresentam aderência integral a disciplina, tem um perfil mais voltado para um exercício digital do que propriamente uma dinâmica com jogabilidade e entretenimento, entretanto também são chamados de games. 


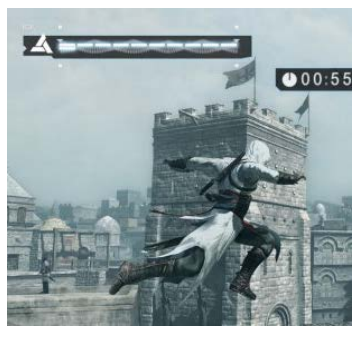

Figura 2.

Assasins Creed (Brotherhood)

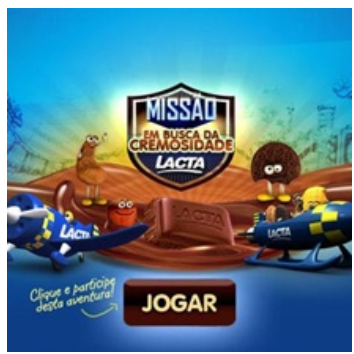

Figura 3.

Lacta

Esses tipos de games propiciam um aprendizado curricular informal e lúdico a partir de um ambiente digital, podendo ser jogado tanto no ambiente escolar como no doméstico.

\section{Games de Entretenimento}

Desenvolvidos meramente para entreter os jogadores, é o mais popular entre os gêneros de game. Propicia um ambiente em que o jogador penetra em um mundo alternativo. Podendo desempenhar o papel de um personagem virtual seja ele de qualquer época ou local. $\mathrm{O}$ avanço da internet permitiu que os games, que possibilitam a opção em jogar com equipes numerosas, se tornassem populares em todo o mundo.

\section{Advergames}

São games projetados como ferramentas de publicidade a fim de divulgar comercialmente algum produto ou serviço. Geralmente, se apropriam de games já conhecidos e são adaptados para o universo da respectiva empresa. Com o uso massivo da internet, os Advergames têm proliferado nos sites de companhias com um público consumidor infanto-juvenil, o que explica a maior quantidade de visitas nos respectivos websites. Os Advergames passaram a fazer parte do planejamento de mídia de certos segmentos comerciais.

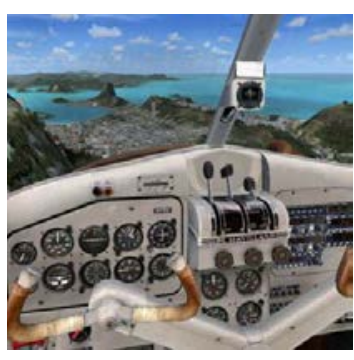

Figura 4.

Flight Simulator 2015

\section{Simuladores}

São ferramentas utilizadas pelas forças armadas ou corporações para fins de treinamento. Reproduzindo ambientes, cenários e objetos do mundo do real com o intuito de desenvolver habilidades ao jogador sem correr qualquer tipo de risco, porém, considerando todos os riscos que aquela atividade demanda na vida real. Com isso, são 


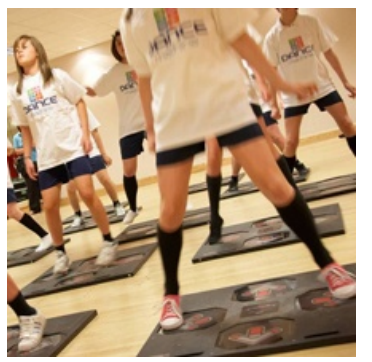

Figura 5.

Exergame em academia

Fonte:

Exergaming Australia

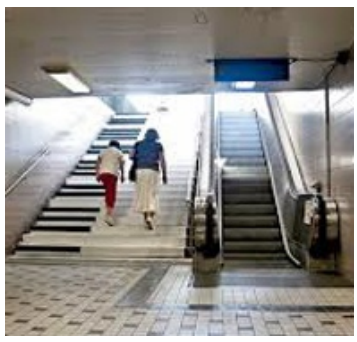

Figura 6.

Gamificação na escada de metrô

Fonte:

G1 produzidas versões mais simples para o público em geral, transformando o que era um treinamento, em um game.

\section{Exergames}

Esse gênero foi desenvolvido para se contrapor aos games que enquadram como um a atividade sedentária e promover um estilo de vida ativo. Uma pesquisa feita pelo American College of Sport Medicine concluiu que os exergames, efetivamente, estimulam o jogador a executar uma atividade de exercícios leves para moderados e aceleram, positivamente, a batida do coração em comparação com os tradicionais games que mantem o jogador sentado, caracterizando o exergame, como uma game que demanda de mais energia e esforço físico do que os games comuns.

\section{Gamificação}

Não é um game, mas se apropria de seus princípios e de sua mecânica em um contexto distinto do ambiente digital. É produzido geralmente em espaços públicos ou corporativos, a fim de envolver o público ou seus funcionários. A gamificação é aplicada em processos a fim de intensificar o envolvimento, melhoria da qualidade, promover a auto-expressão, aprendizado ou incentivo a uma determinada idéia ou atividade. Como no game, também estimula o usuário através do seu desejo natural de competir por intermédio de tarefas, missões ou atividades específicas.

Alguns projetos incluem um tipo de premiação como medalhas, moeda virtual, gráfico comparativo de progresso etc. 


\section{Principais Componentes do Game}

Um glossário tem por objetivo esclarecer o significado de uma série de palavras, termos técnicos e científicos que apresentem uma significação obscura (GOULARTE, 2010). Considerado como fenômeno, os jogos eletrônicos possuem várias nomenclaturas e termos característicos. Esta seção tem por objetivo organizar alfabeticamente, esclarecer os detalhes do fenômeno da pesquisa a partir dos termos mais usados neste meio e do conjunto de palavras citadas ao longo deste trabalho. Serão acrescentados itens à medida que a pesquisa vai se desenvolvendo.

\section{Balanceamento}

Balancear consiste em criar mecanismos na jogabilidade do game, a fim de desafiar adequadamente os jogadores, evitando entediá-los com tarefas triviais ou frustrá-los com tarefas intransponíveis (ANDRADE, 2006).

Para Prensky (2010), o balanceamento é uma das características mais importantes para os games, ao dar ao jogador a sensação de estar sempre se aprimorando. Em muitos dos casos, é o chamado leveling up, o que significa literalmente chegar ao fim de um nível ou fase e começar outro.

\section{Cenários (ou ambientes)}

Correspondem a uma parte da narrativa ficcional que suporta uma situação de interação entre usuário e sistema de jogo. O usuário pode controlar todas as entidades do jogo a partir deste ambiente virtual. Todos os elementos e entidades presentes no cenário são regidos por um sistema programado de regras, assim como o próprio cenário. Resumidamente, correspondem ao palco da ação no game. Por outro lado, podem ser usados para discutir e retratar mundos diversos, representando ambientes característicos tanto de uma fantasia medieval como de mundos futurísticos (AGUIAR, 2010).

\section{Fases (ou níveis)}

Correspondem a estruturas que apresentam desafios na medida em que o jogador avança no espaço do game, com o objetivo de alcançar uma fase ou nível final. Garantem ritmo ao jogo, ditando a forma como se deve distribuir a experiência do usuário e como a intensidade dessa experiência pode ser afetada, dificultando desafios e conflitos a cada troca de fase (AGUIAR, 2010). 


\section{GDD (Game Design Document):}

O documento do game design, GDD, como é mais conhecido, é o principal documento de referência para toda a equipe no desenvolvimento de um game. Montado pelo Game designer, é um registro de todas as características que formam um projeto de game, tanto do ponto de vista conceitual quanto tecnológico. Características conceituais como o nome, gênero, público-alvo, mecânicas de jogabilidade, design dos níveis, caracterização dos personagens, linha de arte e trilha sonora; características tecnológicas, arquitetura do sistema, métodos de produção, hardwares e softwares utilizados e funcionamento da inteligência artificial (NOVAK, 2010). Tudo relacionado ao jogo deve estar reunido neste único documento.

\section{HUD (gráfico de desempenho do jogador)}

Vem da sigla da expressão em inglês "Heads-Up Display”, proveniente de uma ferramenta indicativa de desempenho de pilotos de aviões. HUD corresponde a uma área da interface que disponibiliza informações muito importantes, relacionadas ao desempenho do jogador, tais como: vidas ou nível de saúde, itens, magia e indicativos de sua progressão no game (AGUIAR, 2010). Esses atributos variam de nome e de valor de acordo com o game. Também inclui o inventário dos objetos coletados ao longo da partida.

\section{Inteligência Artificial (IA ou AI, Artificial Intelligence)}

Em Ciência da computação, significa um sistema computacional programado para pensar como um ser humano, para reagir, aprender e exercer funções cognitivas que se assemelham à inteligência humana. Nos games, a IA pode ser livremente empregada para fazer referência a um nível de inteligência programada para o controle de NPCs e outros objetos, determinando como estes podem responder ao jogador ou a outras entidades no jogo (MARX, 2007).

\section{Interface Gráfica}

Em um sistema computacional, a interface corresponde aos mecanismos que permitem a comunicação entre o sistema e o usuário, e pode ser dividida em outgame e ingame. A primeira é a estrutura visual de como apresentar a introdução do game, suas instruções, configurações entre outras operações. A interface ingame consiste na instrumentação disponível do game e pela 
organização visual e exposição da entrada de dados do jogador ao longo de sua partida. Recomenda-se que sua interface seja a mais simplificada e intuitiva possível para que o jogador fique focado na partida e todas as informações relacionadas ao jogo o apóiem de forma eficiente em seus desafios e descobertas ao longo do game.

\section{Personagens}

Dividem-se entre o avatar, também chamado de PC (player character), e os NPCs (non-player character). Existem games que permitem o controle de mais de uma personagem durante a partida. Na maioria dos games, o avatar é uma personagem específica e pré-definida (como o Mario, em Super Mario Bros., Nintendo of America, 2000) ou pode ser construída pelo jogador, desde a escolha de um nome à aparência física, permitindo até a eleição de alguns atributos, como em jogos do tipo RPG e MMOG (MARX, 2007). Quanto aos NPCs (non-player character): normalmente, as NPCs se resumem às personagens controladas pelo computador, no entanto, existem jogos que permitem ao jogador o controle sobre algumas destas entidades.

\section{Storyboards}

Devem ser incluídos no Documento de Arte, pois permitem esboçar algumas cenas do jogo antes de serem finalizadas em softwares 2D ou 3D. Os storyboards costumam mapear cenas não-interativas (cut-scenes) que correspondem a pequenos vídeos de exibição (cinematics) de parte da história do jogo, geralmente apresentadas ao jogador a cada troca de fase. Esse mapeamento serve para prever a ação antes de sua realização no software correspondente, bem como indicar as possíveis correções antes de prosseguir com o desenvolvimento das animações (ROUSE, 2001; MARX, 2007).

\section{Tutorial}

Conjunto de instruções que indicam ao usuário os procedimentos e regras para utilizar um sistema por meio da auto-aprendizagem (NOVAK, 2010). O glossário utilizado por jogadores e desenvolvedores de games estende-se além das significações apresentadas aqui. 


\section{Versões Alfa e Beta}

Chama-se de Versão Alfa ao primeiro protótipo do produto. Este procedimento visa solucionar problemas relacionados à jogabilidade antes que o game seja apresentado ao público. Versão Beta: trata-se de um procedimento aplicado a um estágio de desenvolvimento avançado do produto, quando o jogo está pronto, entretanto, o foco deste procedimento geralmente relaciona-se à busca de erros (bugs) para eventuais ajustes (AGUIAR, 2010).

\section{Profissionais da equipe de desenvolvimento de um game}

Um game pode ser criado apenas por um programador habilidoso e multidisciplinar, mas, segundo NOVAK (2010), como raras exceções, é preciso muito mais que talento para se criar um protótipo funcional que forme a base de um game bem-sucedido.

Independente do processo ou do método adotado, os desenvolvedores necessitam de uma boa equipe de profissionais para que o game seja produzido, mas, nem sempre, todas as funções são ocupadas por pessoas diferentes. Contudo, NOVAK (2010) distingue a equipe em seis áreas principais de desenvolvimento, sendo responsáveis pela produção, o design, a arte, a programação, o áudio e os testes finais.

Visando compreender e classificar o perfil dos profissionais envolvidos, segue um glossário das funções normalmente encontradas nas equipes desenvolvedoras de games:

\section{Animador}

Profissional que aplica e programa os movimentos dos personagens, objetos do mundo dos games. Além dessas animações, há animadores que também se envolvem na criação das animações introdutórias (cinematics). Os animadores devem compreender a dinâmica do game e o desenvolvimento de cada personagem nessa dinâmica. Os tipos de animadores baseados em diferentes aplicações são Animador de Personagem, Artista de Animações Introdutórias e Artista de Efeitos (NOVAK, 2010). 


\section{Conteudista}

A incorporação do projeto de um game a uma narrativa é um desafio totalmente novo. Para complicar ainda mais, um bom game pode derivar de uma boa estória com um começo, meio e fim, entretanto, a estória de um game não é linear como em um livro (NOVAK, 2010). O conteudista deve escrever sobre todas as variáveis e dependendo da demanda do game, criar todos os textos ou diálogos que sejam necessários para a dinâmica e o entendimento do game. No caso do game tratar de um tema muito específico ao tratar de um fato histórico ou de uma específica época, será necessário ter na equipe um conteudista especialista.

\section{Designer Instrucional}

Implementa, avalia e planeja o desenvolvimento de projetos didáticos e metodológicos nas modalidades de ensino presencial ou a distância. Acompanha e avalia os processos educacionais, pesquisa os devidos conteúdos e roteiriza o projeto de acordo com a mídia a ser aplicada.

Diretor de Arte (Art Director ou artista principal)

Responsável pelo Documento de Arte, pelo desenvolvimento e gerenciamento da arte conceitual e dos recursos visuais do jogo como modelos, texturas, animações, elementos gráficos da interface do usuário etc. Desempenha um papel fundamental na criação e aplicação do estilo visual do jogo (ROLLINGS; ADAMS, 2006).

\section{Engenheiro de áudio}

Responsável pelo desenvolvimento e pelo gerenciamento de todos os ativos sonoros presentes no jogo, como música, trilha sonora, sons ambiente, efeitos sonoros, diálogos, narrações etc. (ROLLINGS; ADAMS, 2006). De acordo com Adams (2003), embora as imagens contem ao jogador o acontecimento, o som transmite o sentimento do significado. Dessa forma, a presença do áudio no jogo torna-se tão importante quanto as imagens e as ações, exigindo a pa rticipação de profissionais especializados nessa área. 


\section{Especialista}

Representante da disciplina ou área de conhecimento para a qual o título será desenvolvido.

\section{Ilustrador}

Envolve-se com as questões relacionadas à imagem e aos aspectos visuais do game, quer sejam gráficos 2D, 3D, animação, aplicação de texturas ou modelagem etc. (SILVA, 2004). Seu perfil deve corresponder a de profissionais com habilidade artística para criar os elementos visuais do game, desenhando, colorindo ou modelando componentes. Suas atividades implicam no domínio de tipos de software de manipulação e tratamento de imagem ou vetor, bem como de animação 2D ou 3D.

\section{Game Designer}

A ideia e a composição do projeto constituem parte das responsabilidades deste profissional, que ocupa-se do design do jogo, determinando cada detalhe importante à sua realização (SILVA, 2004). O Game Designer deve planejar e documentar (Documento de Design, mais conhecido como GDD - game design document) todo o funcionamento do jogo, ou seja, o modo de jogar, seus níveis e sua interface. O GDD serve como documento de referência para toda a equipe. O Game designer corresponde a uma função interdisciplinar, uma vez que seu trabalho é desenvolvido com outros profissionais da equipe. Dependendo da complexidade do game, segundo Jeannie Novak, suas funções podem ser distribuídas a mais de um profissional, com um responsável somente pela criação e funcionamento, outro pelos níveis e outro só para a interface.

Gerente de projeto (supervisor, diretor geral ou Lead Designer)

Profissional responsável pelo gerenciamento e supervisão de todo o projeto, acompanhando o processo em seu nível mais abstrato, ou seja, a partir de sua concepção. Corresponde ao líder da equipe, o profissional que responde interna e externamente pelo projeto (ROLLINGS; ADAMS, 2006). 


\section{Designer de Interface (Interface Designer)}

Dependendo da complexidade do game, o game designer pode demandar um profissional somente para o detalhamento do layout, o conteúdo e as características de navegação e usabilidade da interface do game. Segundo Novak, a equipe de arte se envolve em sua criação, após a estrutura da interface estar definida.

\section{Designer de Níveis (Level Designer)}

Responsável por planejar os níveis ou fases dentro do jogo (MARX, 2007). A partir do Documento de Design elaborado pelo Game Designer o Level Designer deve projetar e construir os níveis individuais que o jogador deve enfrentar durante as partidas (ROLLINGS; ADAMS, 2006). Além dos níveis, esse profissional elabora e descreve mapas, regiões geográficas ou zonas, disposição de componentes dentro do jogo, características dos ambientes, personagens etc. Para tanto, pode utilizar ferramentas tanto de arte como de programação (MARX, 2007).

\section{Programador (Game Programmer ou Engenheiro de programação)}

Reponsabiliza-se pelo núcleo do jogo, como define Silva (2004), por meio de um trabalho que se relaciona com a atividade de vários outros profissionais. A programação encontra-se presente nas configurações, na engine, no banco de dados, na inteligência artificial (IA), na modelagem 2D ou 3D, na física e nos algoritmos, bem como em todos os elementos de implementação que necessitem da configuração de um código fonte para “dar vida ao jogo”. Dependendo da complexidade do game, serão necessários outros perfis de programadores como: de Rede, de Inteligência Artificial e ou de Física (NOVAK, 2010). Geralmente há uma demanda de um Analista de Sistemas para organizar todas as informações geradas ao longo do game através de um banco de dados.

\section{Operador de Testes (Game tester)}

Responsável pelos testes e pelo controle de qualidade do produto. O Game tester deve jogar o jogo e realizar uma série de testes na versão alpha test, visando encontrar problemas de jogabilidade e reportá-los ao Game Designer. Após os devidos ajustes, quando o projeto estiver muito próximo de ser concluído, uma versão beta test deve ser preparada para novos testes, a fim de localizar possíveis erros (bugs) ou imperfeições nesta versão e reportá-los aos responsáveis, a fim de 
que a equipe de desenvolvimento possa solucionar os problemas e gerar a versão final do jogo (MEIGS, 2003). O número de Game testers varia de acordo com a complexidade, porte e prazo do projeto.

Considerando os profissionais citados para formar uma equipe capacitada a fim de produzir games educativos, apresentamos sua organização no Diagrama 2 a seguir:

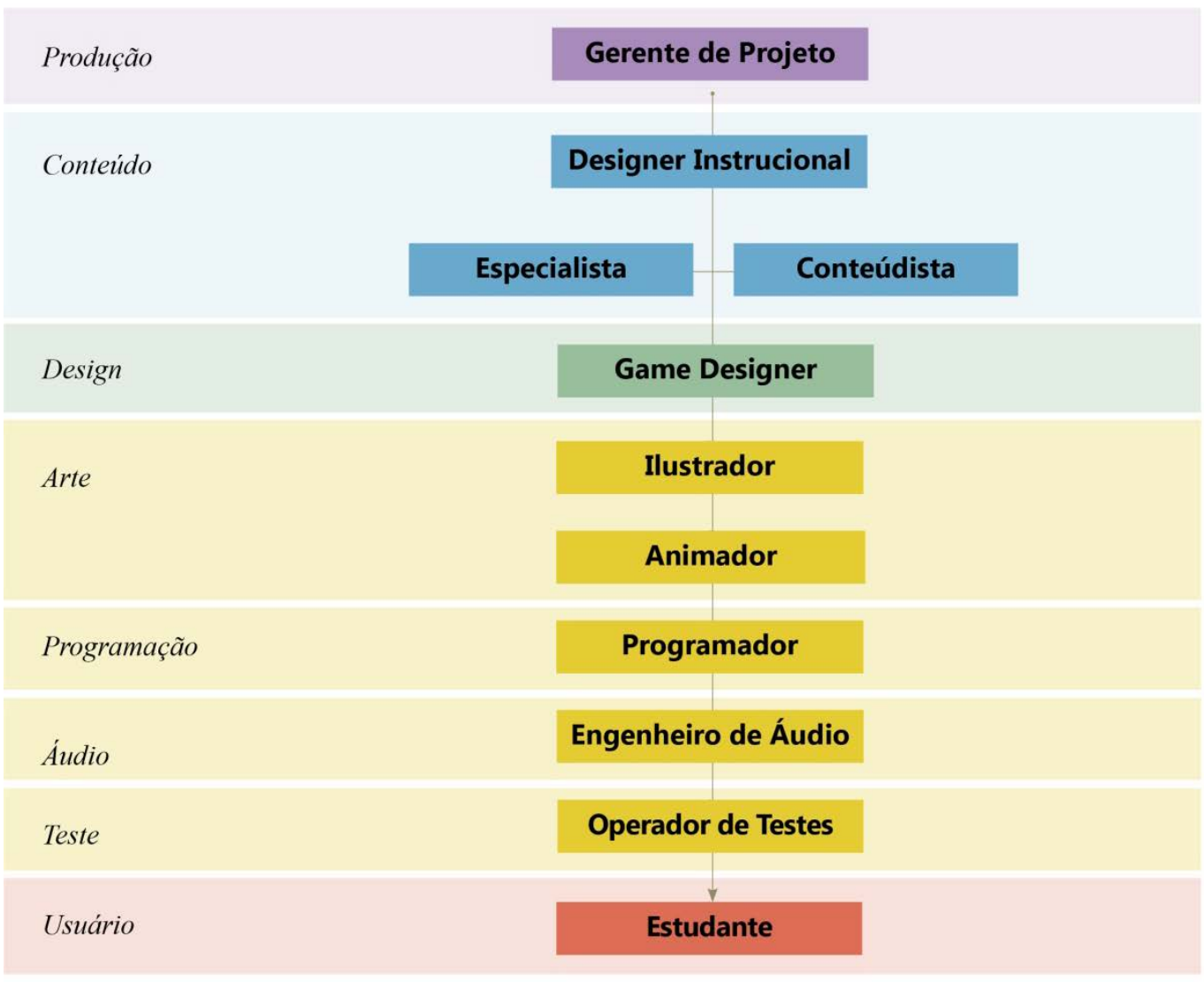

Diagrama 6. Organograma da equipe para a produção de games

Profissionais da área de jogos, em diferentes empresas ou situações, podem apresentar uma variedade de nomenclaturas e termos distintos daqueles citados nesta seção. No entanto, as significações aqui apresentadas fizeram-se por meio de um levantamento geral dos diferentes termos, nomenclaturas e definições encontrados na literatura da área de jogos eletrônicos.

A partir do momento que temos uma estrutura profissional para desenvolver games educativos, é necessário ter clareza sobre conceitos que fazem desses objetos de aprendizado, realmente úteis e aplicáveis a indivíduos que estão em um processo de educação formal. Para isso, é necessário ter um entendimento 
de quem é esse usuário, saber do potencial educacional que um game pode oferecer e de que forma pode ser feito, aliando o papel do design na sua concepção e desenvolvimento e como fazer com que games educacionais sejam tão atrativos quanto games de entretenimento.

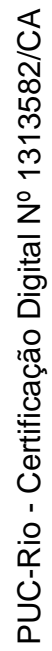




\section{3.}

\section{Games: seu potencial educacional e pedagógico}

Em torno da virada do século XXI, os games se estabeleceram mundialmente como um produto de diversão e entretenimento. Nas regiões mais favorecidas do planeta, as crianças têm aprendido a manipular celulares (smartphones) e tablets antes mesmo de aprender a falar, além dos jovens que desfrutam por horas, debruçados, alguns excessivamente, sobre seus computadores e consoles de games com suas versatilidades. Ao que tudo indica, o crescimento exponencial do mundo dos games está longe de encontrar o seu limite. Números do setor, segundo o site de tecnologia Tecmundo, apontam que as vendas de consoles, games e serviços relacionados a games online, em 2010 ultrapassaram os US\$ 60,4 bilhões anuais, podendo chegar a US\$ 75 bilhões até 2015. Para se ter uma ideia da relevância desse montante, nessa mesma época os filmes produzidos em Hollywood faturaram pouco mais de US\$31,8 bilhões.

Com todo esse encantamento, crianças e jovens têm feito uso de novos paradigmas de comunicação, mídia e lazer, se distanciando, e muito, das tradicionais metodologias de aprendizagem e educação, que segundo Silva (2010), tornaram-se burocratas do saber-produto, da escola-fábrica.

Por essa razão, há uma grande demanda para a criação de novas metodologias educacionais e preparação do corpo docente para se apropriar dessa nova cultura tecnológica tão apreciada por seus alunos, das quais os professores podem se beneficiar. O sociólogo Marco Silva (2010), se refere a esse aluno como novo espectador que está se acostumando a tela multiforme, cada vez menos instrumental e em busca de um processo comunicacional complexo de modificação e controle sobre os acontecimentos. E Prensky (2010) sugere que o processo de adaptação a novas tecnologias podem se iniciar no âmbito doméstico até que seja materialmente viável nos ambientes de ensino público e particular. Enquanto isso, de acordo com o game designer americano, deve-se priorizar um currículo digital doméstico para essa 
geração de alunos que estão familiarizados ou são ávidos usuários das TICs como veremos a seguir.

\section{1.}

\section{Público-alvo}

\section{Nossos usuários já nasceram na era digital}

A geração de jovens, nascida em meio a computadores, internet, games e tantos outros recursos digitais, chamados de "nativos digitais” por Marc Prensky (2008), incorporaram de tal forma essas mídias que sequer as percebem como tecnologia. Para eles, o acesso à informação deve ser rápido, quase imediato e, por isso, como destaca Mattar (2010), recorrem à internet ao invés de meios impressos tradicionais. Para isso, utilizam seus computadores, tablets ou celulares, que também servem como tocadores de mídia (música ou vídeo) ou mensagens de textos nos celulares, etc.

De formas distintas, a geração X (35 a 50 anos) tem o costume de se comunicar através de texto e fala, entretanto as gerações Y (25 a 34 anos) e Z (17 a 24anos) que fazem mais do uso simultâneo de mídias, como demonstrado na pesquisa a seguir:

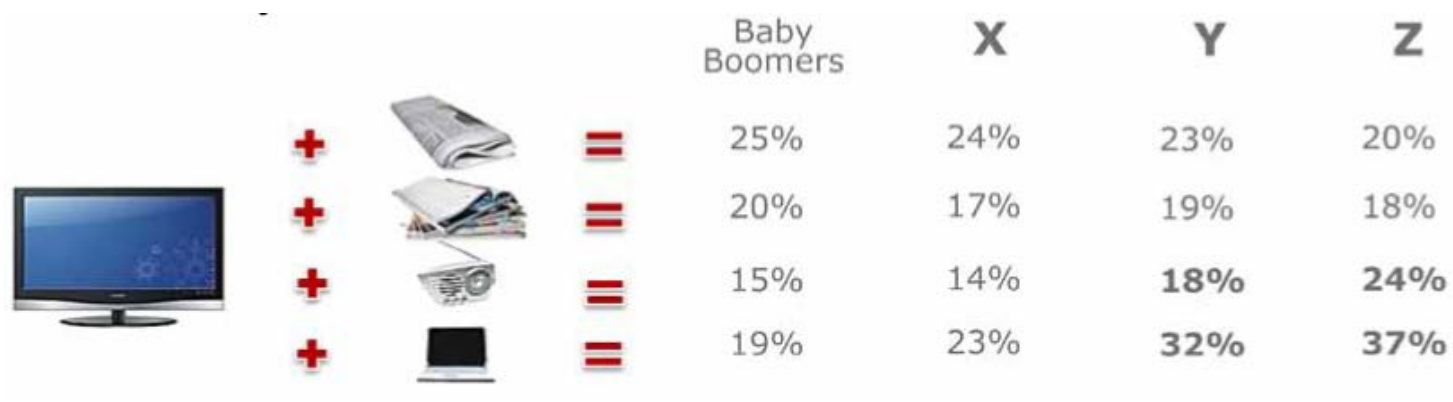

Diagrama 7. Comparativo de simultaneidade das atividades de mídia Fonte: IBOPE Mídia 2010

As gerações mais jovens se comunicam e compreendem histórias através de informações descontinuadas, como Win Veen (2010) demonstra a seguir, ao pesquisar alunos de 10 anos de idade que, ao mesmo tempo, assistem a um seriado na TV, estudam e ouvem música: 


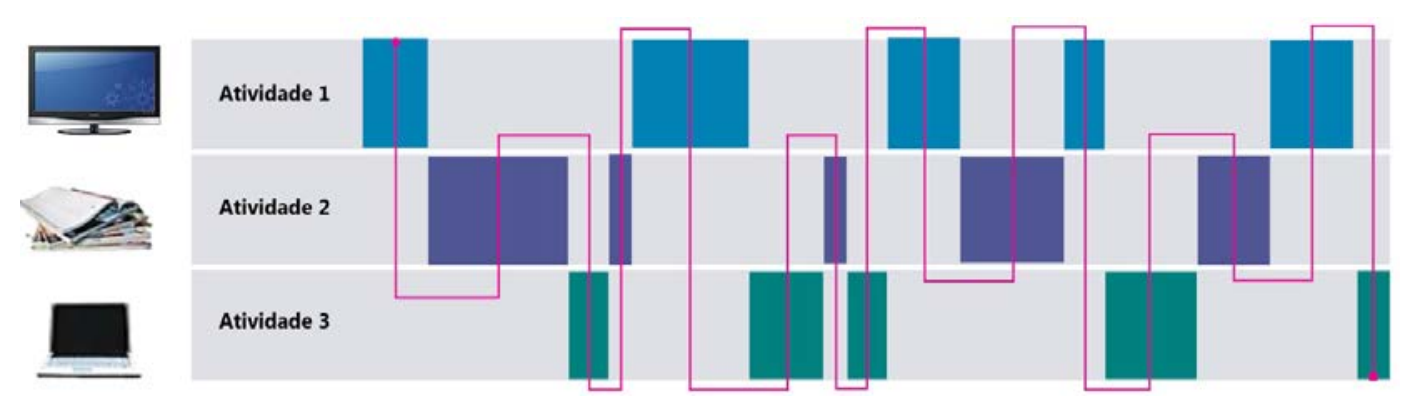

Diagrama 8. Fluxograma de atividades de um aluno de 10 anos

Fonte: Win Veen, 2010

Esses “nativos digitais” representam a primeira geração que não apenas cresceu rodeada pelas novas tecnologias, mas que a incorporaram como ferramentas no seu dia-a-dia, tal como descreve a metáfora de Derrik de Kerkove (2009). Entretanto, usuários adultos ou nascidos antes da popularização das novas mídias, são chamados por Prensky (2010) de “imigrante digitais”, cujo contato com as novas tecnologias pode parecer temeroso e algo a ser desvendado.

Portanto, os "nativos digitais” de acordo com o game designer americano:

- estão acostumados a receber informações muito rapidamente;

- gostam de processar mais de uma coisa por vez e realizar múltiplas tarefas;

- $\quad$ preferem os seus gráficos antes do texto ao invés do oposto;

- preferem acesso aleatório (como hipertexto);

- trabalham melhor ligados a uma rede de contatos;

- têm sucesso com gratificações instantâneas e recompensas frequentes;

- e preferem games a trabalhos "sérios".

Contudo, o conceito de "nativo digital" foi questionado e corrigido pelo próprio Prensky (2010) para "sábio digital” por ser mais assertivo, quando questões sócio-econômicas não proporcionam a um suposto "nativo digital” acesso a ferramentas e conhecimentos tecnológicos.

Quanto ao sábio digital, ele tem o perfil de:

- se informar através de ferramentas digitais e de multimídia;

- se estimular a partir de desafios, de sua criatividade e por sua auto-estima;

- se orientar por ícones, teclados e menus;

- apreciar produtos e serviços personalizados;

- considerar a amplitude de suas redes sociais como uma referência ; e

- apreciar o compartilhamento digital de informações pessoais. 
Com isso, estabeleceu-se uma diferença "natural” do conhecimento digital entre os alunos e os professores. Está cabendo aos professores de hoje ter de aprender a se comunicar na língua e estilo de seus estudantes. Isto não significa mudar o significado do que é importante, ou das boas práticas de pensamento. Isso significa, aprender mais rápido, com menos passo-a-passo, mais temas e atividades paralelas, entre outras coisas.

O uso da tecnologia da informação pode e deve contribuir para a educação. De acordo com Papert (1986), o uso do computador é defendido como auxiliar no processo de construção de conhecimentos, uma poderosa ferramenta educacional, adaptando os princípios do construtivismo cognitivo de Jean Piaget, a fim de melhor aproveitar-se o uso de tecnologias.

Para reforçar o que Papert nos sugeriu desde os anos 1980, o educador João Mattar (2006) é crítico ao comentar que as escolas utilizam ferramentas e sistemas de educação e avaliação de ontem procurando formar pessoas para o amanhã. Além do uso de materiais sem inovação, há uma questão de resistência que é relatada por mais um educador:

Em lugar de posicionar-se diante da experiência comunicacional vivida pelos alunos, a escola continua na defensiva. Enquanto os alunos apresentam-se como novos espectadores, tendendo para uma postura menos passiva diante da emissão e recepção. (Marco Silva, 2010, p.82)

Na escola, a sala de aula pode ser rica em interatividade, segundo Silva (2010) uma vez que o que está em questão é o movimento contemporâneo das tecnologias e não necessariamente a presença da infotecnologia. Seus softwares educativos não devem possuir metodologias fechadas, a fim de estimular a interatividade de alunos e professores. Abrindo-se um novo universo de conexões e experimentações mobilizando diversos campos de conhecimento em uma rede inter/transdisciplinar para estimular a participação criativa dos aprendizes.

Na sociedade contemporânea, generosa em tecnologia que nos liga a redes e é abundante em informações, de acordo com Schwartz (2014), estamos sendo conduzidos a repensar o lugar da escola, da pedagogia e da criatividade nesses novos espaços comunicacionais, em que se constrói a cada interação uma narrativa que ocupa um lugar no mundo real e, também, no virtual. 


\section{2}

\section{Educação}

\section{O processo de evolução da tecnologia no ambiente de ensino-aprendizagem}

E o ser-humano desenvolveu a sua comunicação com o próximo. Desenvolveu idiomas e dialetos. Constituiu a tradição oral e a contação de histórias. Passados algumas eras, inovou e desenvolveu a escrita e após um par de milênios, Gutemberg com sua prensa (1455) deu início a uma ampla distribuição de conhecimento, através da impressão mecânica sobre o papel, para todo o mundo. Contudo, após alguns séculos, o homem passou a desfrutar das tecnologias audiovisuais (anos 1970), para logo em seguida, inovar, na virada da década, em torno do universo digital (computador, seus acessórios, a internet, os celulares e os aparelhos móveis). Cada uma dessas tecnologias de informação e comunicação (TICs) provocou processos históricos, psicológicos, culturais e sociais na humanidade.

Nesse processo, a palavra escrita foi a primeira tecnologia de comunicação de massa. Sua característica foi permitir a acumulação de conhecimentos ao criar um meio de registrar e armazenar informações, o que não era possível em uma cultura não-letrada, transformando o processo do pensamento, como a classificação, o raciocínio e a memória.

Valente (1999), educador brasileiro, comenta o quanto precisamos nos dar conta, de que a escrita é uma tecnologia como o audiovisual ou a informática. E que também gerou resistência nas sociedades de oralidade primária. Como Platão, que se mostrou receoso da escrita como uma tecnologia que viria diminuir a capacidade de memória presente na oralidade. A escrita, ao possibilitar o registro, libertou a mente do esforço de recordar. Mas, mesmo assim, a sociedade se apropriou dessa tecnologia, fazendo com que a escrita desse início a uma nova realidade. Mas como nos diz Ponte (2000), sabemos que toda “técnica” nova só é utilizada com desenvoltura e naturalidade no fim de um longo processo de apropriação.

Cris Crawford, em seu livro “The art of computer game design” (2001), faz um comparativo entre a narrativa linear e a narrativa digital (não-linear) como os games. Pois, a narrativa linear apresenta os fatos em uma sequencia imutável, enquanto um game apresenta uma ramificação da árvore de sequencias e permite ao jogador criar sua própria história ao fazer suas escolhas. 
O público de uma narrativa linear se envolve nas relações de uma única sequencia de fatos, seja contada oralmente, através de um livro, um filme ou um seriado de televisão (Diagrama 5); por outro lado, o jogador de um game é encorajado a explorar alternativas e contrapontos. O jogador é livre para explorar a relação causal de muitos ângulos diferentes. Com esse efeito, o jogador espera jogar o jogo muitas vezes, tentando estratégias diferentes a cada vez. A estória é para ser experimentada uma vez; seu valor representativo diminui com releituras subsequentes, pois não apresenta nenhuma informação nova. $\mathrm{O}$ valor representativo do game aumenta com cada nova rodada até que o jogador tenha explorado um subconjunto representativo de todas as possibilidades do game.
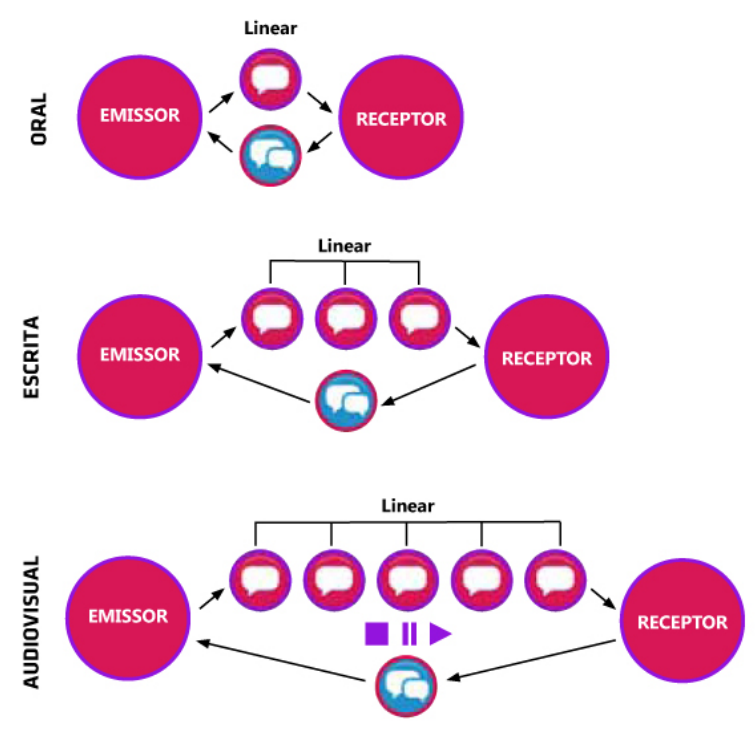

Diagrama 9. Comparação entre as estruturas de narrativa de diversas mídias Fonte: $\mathrm{O}$ autor

Isso não significa que os games são melhores que as estórias com suas narrativas lineares, porém são distintos modos de expressão. Afinal, para Cris Crawford, o diferencial criativo das estórias é sua riqueza de detalhes. Entretanto, para Silva (2010), houve uma significativa transformação, em que a mensagem passou de fechada para mutável, o emissor de “contador de histórias” a “designer de um território navegável” e o receptor de passivo a cocriador.

Diante desse intenso processo, no decorrer do século XX, Van Eck (2008) nos alerta que nos anos 1960 e 1970, o áudio e o vídeo (mais tarde a TV) estavam sendo considerados tecnologias que iriam revolucionar o aprendizado. Muitas escolas nos EUA e na Europa se adaptaram para o seu uso, porém nos anos 1980, 
pesquisas relataram que as mudanças não foram tão significantes assim. Usar um novo tipo de mídia, demanda um alinhamento com novas estratégias e métodos pedagógicos, e seu currículo. Nos casos em que esse alinhamento é superficial a mídia cai em desuso ou nem é utilizada.

Contudo, a psicóloga americana Greenfield (1988), baseada em estudos de Miri Ben-Moshe e Gavriel Solomon, Pezdek e Lehrer, e Jessica Beagles-Ross, reconhece que ao acrescentar imagens visuais dinâmicas, as informações apresentadas verbalmente tornam-se mais fáceis de serem lembradas e absorvidas pelas crianças. Desse modo, para transmitir informações, as TICs com sua interatividade e impacto visual são tecnologias ainda mais eficientes que a televisão, por sua vez, mais eficiente que o rádio, a escrita e a oralidade. No Diagrama 4 podemos observar um comparativo da estrutura narrativa de cada mídia. A televisão têm dinamismo, mas restringe a participação do espectador, já as TICs possibilitam a combinação do dinamismo visual com uma participação ativa por parte do usuário.

Para complementar essa análise, temos o estudo que Patrícia Greenfield desenvolveu ao longo de 1988, e tudo o que ela fala sobre a televisão se adequa perfeitamente as TICs do séc.XXI. A autora sugere que a televisão deveria ser mais usada nas escolas para transmitir informações. Mas deveria ser usada com discussões em classe dirigidas pelo professor. Assim como os pais deveriam restringir o número de horas que seus filhos passam assistindo à televisão em casa, a fim de usar outros meios e experiências para promover a reflexão e a imaginação. E devido à televisão ser um meio tão poderoso como recurso didático, é muito mais importante que as crianças sejam expostas a uma programação de qualidade que: (1) não vá além de sua maturidade emocional e (2) proporcione fantasia ou apresente fantasia ou apresente fatos que sejam úteis, não nocivos, à vida real.

Portanto, devido a essas experiências anteriores tem se formado equipes multidisciplinares, assim como, têm sido feito testes para melhor integração entre a tecnologia da computação, informação, comunicação e educação.

Hoje, conhecemos um novo suporte de escrita e de leitura. As letras transformaram-se em hipertextos e a página passou a ser a tela de um tablet, celular ou monitor e, o lápis, o nosso próprio dedo, teclado ou o mouse.

É um novo modo de lidar com a informação que invade nosso ambiente, pois a hipermídia disponibiliza sentidos táteis, visuais e sonoros em sistemas de forma bastante fluida e, ainda, aliada a internet possibilita uma comunicação interativa 
proporcionando uma nova forma de nos relacionarmos com o conhecimento. Formou-se uma nova forma de alfabetização, a digital. (PORTUGAL, 2013, p28)

Até muito recentemente, para se educar as crianças, utilizavam-se livros, textos, enciclopédias (quando tinham uma), bibliotecas (se havia uma disponível e se era boa) e algumas perguntas dirigidas a um professor já sobrecarregado. Isso costumava funcionar para alguns alunos brilhantes, mas não para a maioria.

A tecnologia atual, no entanto, disponibiliza aos alunos diversas ferramentas que favorecem o aprendizado e os estudos. Que oferecem autonomia para que os alunos pratiquem e estudem de acordo com a demanda de que cada um necessite, permitindo àqueles com maior dificuldade que se utilizem de ferramentas que o favoreçam e os estimulem no início de seu processo de aprendizagem, enquanto que um aluno mais avançado, explore algumas mais complexas. Sendo assim, em uma estrutura não-linear como é oferecido pelas TICs, é possível que um aluno mais adiantado possa avançar, em uma medida distinta de seus colegas que têm mais dificuldade.

\section{A tecnologia envolvendo a educação}

Para Candau (1997), educadora brasileira, a escola é a base para a construção de saberes e de conhecimentos, e seu papel é o de formar sujeitos críticos, criativos, que dominem um instrumental básico de conteúdos e habilidades de forma a possibilitar a sua inserção no mundo do trabalho e no pleno exercício da cidadania ativa.

Assim, questões como a globalização, o multiculturalismo, de gênero e raça, as novas formas de comunicação, as manifestações culturais de adolescentes e jovens, as expressões de diferentes classes sociais, os movimentos culturais e religiosos, as diversas formas de violência e exclusão social configuram novos e diferenciados cenários sociais, políticos e culturais.

A teoria educacional e a didática não podem ignorar essa realidade. De acordo com Candau, o impacto desses processos no cotidiano escolar é cada vez maior. E os professores encontram-se despreparados para exercer sua função tendo presentes essas realidades. Então, nos vemos à frente em um processo desafiante e enriquecedor para a didática, o ensino e a aprendizagem. 
De acordo com Rui Canário (2006), pesquisador português, doutor em ciências da educação, estamos frente a um problema que transcende a ação individual do professor e o território da sala de aula, mas que diz respeito ao ambiente da aprendizagem global, definida pela escola na condição de organização. Também não é possível intervir e mudar qualitativamente este ambiente global de aprendizagem, deixando intocável o elemento que constitui a sua matriz organizacional de base: a organização dos alunos em classe, com as relativas consequências organizacionais de espaço, tempo e compartimentalização de saber em disciplinas.

Por outro lado, a experiência cotidiana revela a muitos profissionais da educação que a simples carência da atualização da relação de ensinoaprendizagem e a falta de adaptação do modelo educacional às tecnologias de informação e comunicação (TICs) se tornaram alguns dos grandes fatores de enfraquecimento do processo de ensino.

O aluno precisa de “desconectar” de casa e ir para escola, segundo Prensky (2010), onde o tradicional ensino linear mantém o aprendizado na direção contrária das inovações do Séc. XXI (Figura 13). Isso nos remete a um dos legados da era industrial que foi a separação entre os espaços do trabalho e da diversão.
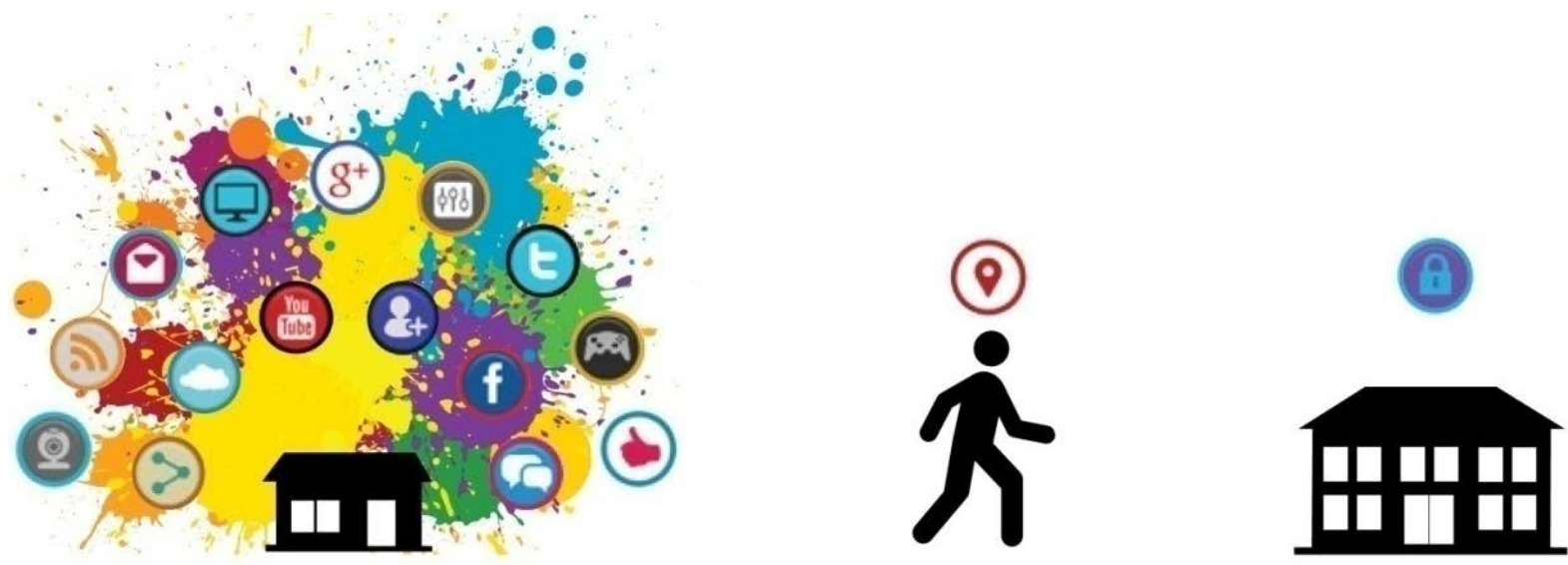

Diagrama 10. Desligando-se das “atividades” digitais para ir à escola Fonte: $\mathrm{O}$ autor

Portanto, atender a necessidade desse nosso “novo” usuário, é o objetivo ao fazermos uso de um sistema de interação humano-computador, afirma Portugal (2013). Essa tecnologia deu base a uma nova sociedade, consequentemente, precisamos nos apropriar dela e com responsabilidade adaptá-la e transferi-la para o campo da educação. 
É inevitável que tenhamos de inserir o uso de tecnologia na sala de aula. Portanto, é necessário acabar com a resistência de professores e pedagogos. (Vera Candau, 2008, p.8)

Essas tecnologias de informação, desde a televisão até os computadores e todas as suas combinações, de acordo com Papert (1996), abrem oportunidades sem precedentes para a ação a fim de melhorar a qualidade do ambiente de aprendizagem, assim como aprimoram as atividades no ambiente de trabalho.

Para que a tecnologia tenha efeito positivo no aprendizado, em primeiro lugar, o professor tem de mudar o jeito de dar a aula. Segundo o educador holandês Win Veen (2010), em menos de 5 anos, 50\% do conhecimento do mundo será desconhecido pela grande maioria, de tanto que se produzirá conteúdo com as TICs nos próximos anos. Quanto aos alunos, eles precisam estar inseridos nesse processo, tanto na produção desse conteúdo como saber em como adquirir informação.

Portanto, as características essenciais na aplicação de ferramentas das TICs - simulação, virtualidade, acessibilidade, a abundância e extrema diversidade de informações - são dessa nova era, e demandam concepções metodológicas muito diferentes das metodologias tradicionais de ensino baseadas num discurso linear, cartesiano e positivista. Sua utilização com fins educativos exige mudanças radicais no modo de compreender o ensino da didática (SILVA, 2010).

Devemos mesclar de forma criativa a pedagogia com a tecnologia e criar ambientes de aprendizagem inovadores, soluções e currículos que empoderem o professor e envolvam os alunos. Para o educador e game designer americano Marc Prensky (2008), o papel da tecnologia, dentro e fora da sala de aula, é o de oferecer suporte ao novo paradigma de ensino.

Ainda assim, professor e escola preparados, paramentados e bem organizados não são garantia de que a atenção e motivação dos alunos durante as aulas e demais atividades será satisfatória.

A ação pedagógica do professor não pode estar nem além nem aquém do nível de desenvolvimento da criança e, sim, um pouco adiante, de forma a constituir um desafio alcançável [...], interagindo-se com o meio e resolvendo problemas. (Freire, 2006, p.114)

É em torno desse universo entre o nível de desenvolvimento e a adequação da educação às novas tecnologias que precisamos desenvolver novas estruturas para o ensino-aprendizagem. 


\section{Ensino-aprendizagem}

Temos a impressão de adentramos a um "novo mundo", pois estamos tratando de novos paradigmas em torno das situações de ensino-aprendizagem. As tecnologias da informação e comunicação (TICs) têm se apresentado através de ininterruptas inovações com as quais somos seduzidos ou simplesmente precisamos nos adaptar para que possamos usufruir de uma grande variedade de serviços. É a evolução tecnológica em todas as áreas da sociedade contemporânea. E a educação não deve se privar desse processo, pelo contrário, precisamos envolver nossos estudantes o quanto antes diante desses novos paradigmas e que seus professores se prepararem para esse passo.

A situação ensino-aprendizagem tem como foco se desenvolver em torno das relações entre professores, alunos, informações e conhecimentos. Seu princípio básico é potencializar o processo de construção do conhecimento.

Esse novo paradigma para a educação e a pedagogia, ao citar a "situação de ensino-aprendizagem” combinada ao uso de conteúdo digital, é muito defendida pelo o educador americano, Prensky (2010), ao comentar que nessa nova pedagogia o papel do aluno passa a ser de pesquisador, de usuário especializado em tecnologia. E o professor passa a ter papel de guia e de "treinador", estabelecendo metas com os alunos, garantindo a qualidade da produção da classe (Figura 14). Estabelecendo a escola como uma instituição não só como reprodutora, mas acima de tudo como produtora.

Para isso, ela propõe interconexões

MODELO TRADICIONAL DE SALA DE AULA

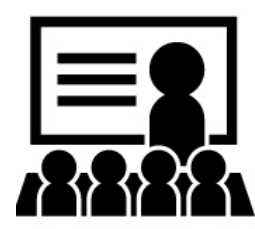

Aula na escola

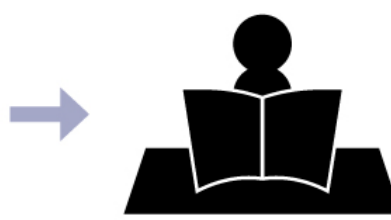

Dever-de-casa

MODELO DE SALA DE AULA INVERTIDO (FLIPPED CLASS)
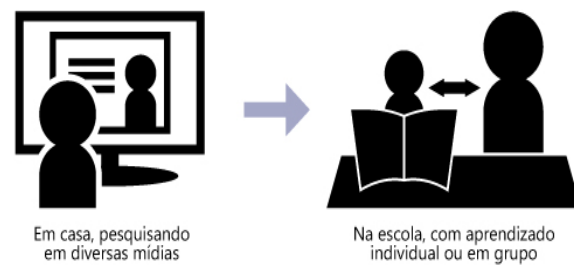

Diagrama 11.

Modelo educacional com sala de aula invertida

Fonte: Prensky (2008) entre os diversos campos do saber, criando subsídios para o planejamento de ambientes hipermídias educacionais, a partir de um olhar múltiplo e inclusivo para que se possa entender como se dá o processo de construção do conhecimento. Estes são compostos por referenciais sobre: competências e habilidades, uso de tecnologias, multiculturalidade, e as demais teorias e referenciais que privilegiam ou tenham como enfoque o indivíduo e seu desenvolvimento integral. 


\section{Conteúdo digital: produzindo um ambiente educacional hipermídia}

Precisamos nos apropriar de muitas das possibilidades que possam contribuir para a construção do conhecimento e preparar os alunos para o mundo do trabalho. O uso de lousa digital, computadores, tablets e celulares e outras dezenas de tecnologias interativas, segundo Portugal (2012), oferecem muitas possibilidades tanto ao professor como ao aluno, pois elas permitem que ambos se apresentem e trabalhem de diversas formas, utilizando recursos visuais, sonoros, táteis do amplo ambiente educacional hipermídia, onde os alunos podem aprender através de ilustrações, fotografias, animações, vídeos, sites, blogs e games de uma forma mais lúdica e dinâmica.

A seguir, apresentamos um mapa de um ambiente educacional hipermídia com muitas das possibilidades que podem ser utilizadas no ambiente escolar. São tantas as ferramentas, desde ferramentas que auxiliam na montagem de trabalhos escolares, de consulta de conteúdo, de armazenagem de dados a objetos de aprendizado:

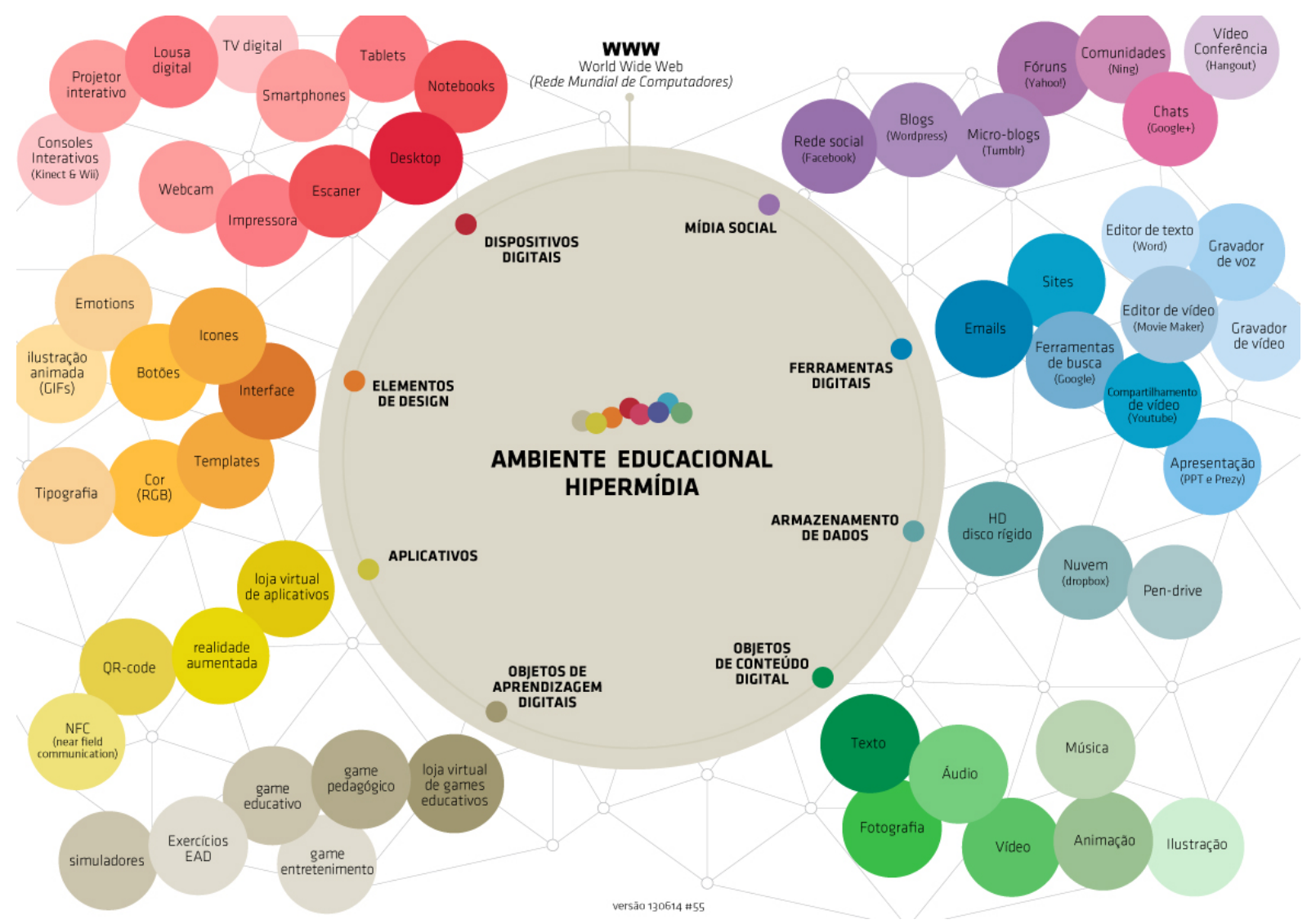

Diagrama 12. Mapa de ambiente educacional hipermídia 
É por essa razão, que Prensky faz um alerta ao dizer que introduzir novas tecnologias na sala de aula não melhora o aprendizado automaticamente, porque a tecnologia dá apoio à pedagogia, e não vice-versa.

Win Veen em seu livro Homo Zappiens (2008), apresenta a tecnologia como uma ferramenta pedagógica e não como uma forma de ensino. No quadro a seguir, o autor exemplifica algumas ações, ao relacionar atividades com o uso de objetos de aprendizado digitais e sua função pedagógica.

$\begin{array}{rrll}\text { RESPOSTAS TECNOLÓGICAS } & & \text { RESPOSTAS CONSTRUTIVISTAS } \\ \text { Fazer apresentação com o Prezi } & \mathbf{1} & \text { Apresentar teorias e novas ideias } \\ \text { Iniciar um blog } & 2 & \text { Estimular debates } \\ \text { Montar seu perfil no Facebook } & 3 & \text { Encontrar respostas a suas perguntas } \\ \text { Formar um grupo no Google+ } & \mathbf{4} & \text { Agrupar parceiros } \\ \text { Produzir e subir videos no Youtube } & \mathbf{5} & \text { Mudar pensamentos } \\ \text { Publicar no Tumblr } & 6 & \text { Fazer a diferença } \\ \text { Usar a lousa digital } & \mathbf{7} & \text { Tomar atitude } \\ \text { Desenvolver um aplicativo } & \mathbf{8} & \text { Inovar }\end{array}$

Quadro 2. Respostas tecnológicas x respostas construtivistas

Fonte: Win Veen (2010)

Além de alfabetizarmos digitalmente o aluno, é necessário termos conhecimento de como envolver pedagogicamente, tanto os alunos que são nativos digitais, como os imigrantes digitais. É necessário desenvolver o conteúdo pedagógico digital como um objeto de aprendizado que precisa ser encapsulado por um objeto de didática e seu conteúdo, para que se torne uma eficiente ferramenta educacional. Segundo o educador holandês Win Veen (2009), é muito importante ensinar os alunos em como fazer uma pesquisa na internet, empoderálos com a grande oferta de informação disponível e ensiná-los a formatar um trabalho com o auxílio de ferramentas digitais com as quais precisamos desqualificar a ação do tipo “CTRL C x CTRL V”, valorizando o questionamento e a redação em detrimento de simples cópias de texto.

É fundamental que os alunos se apropriem e façam uso das ferramentas tecnológicas disponíveis, a fim de registrar e disseminar suas culturas locais, como podemos perceber nos depoimentos a seguir: 


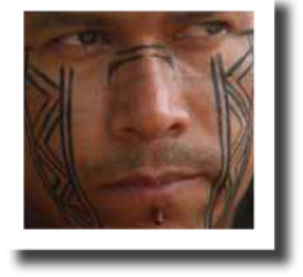

Karkajú Pataxó

35 anos

Aldeia Monte Pascoal BA

"É muito importante podermos dominar novas tecnologias possibilitando a qualificação profissional, poder adequar em nossa lingua e dismistificar a ideia que nós índios não queremos novas tecnologias. Não perderemos nossos costumes e sim teremos novos meios de difundi-la."

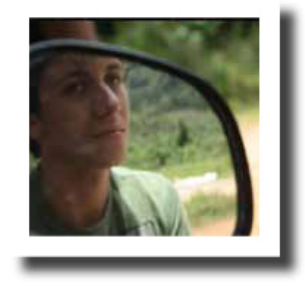

Luis Felipe Silva

18 anos

Vale do Matutu

MG

“Inibir o uso da tecnologia não é a
solução, mesmo porque ela se faz
presente em todo canto. O jovem
rural precisa de conhecimentos
tecnológicos aprimorados para
obter o melhor cultivo, seja
tradicional ou orgânico, e a
internet para a obtenção de
informações e contatos para o
escoamento da produção."

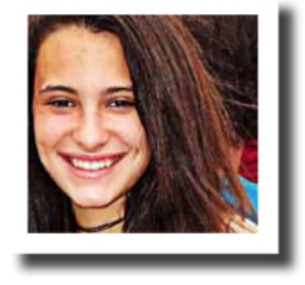

Moana Reis Farias

14 anos

Rio de Janeiro RJ

\begin{abstract}
"Gosto de escrever e dançar, e curto fazer várias coisas ao mesmo tempo, tipo estudar, ouvindo música e vendo um seriado. Entro em contato com os amigos através do WhatsApp, Facebook, Tumblr e Snapchat. Muitas vezes, acho as aulas chatas e adoraria poder estudar de forma mais divertida!"
\end{abstract}

Esses depoimentos reforçam o quanto as tecnologias como emails, chats, comunidades de aprendizagem e fóruns de discussão oferecem espaços para a troca de experiências sobre interesses comuns, além de serem capazes de aproximar e conectar indivíduos que talvez nunca tivessem oportunidade de se encontrar pessoalmente. Portanto, se a aprendizagem é um processo contínuo, pessoal e que implica desenvolvimento e mudança, vale a pena contar com uma série de sugestões inovadoras para aproveitar as oportunidades de aprendizagem. Utilizando metodologias mais convincentes e atraentes como as ofertadas pelas tecnologias da informação e comunicação (TICs).

No campo de projetos de hipermídia, a designer Portugal (2013), o trata como uma das chaves para dar apoio às novas metodologias pedagógicas, nas quais temos a possibilidade de digitalização de imagens, textos, sons, ilustrações, editar e apresentar com a finalidade de comunicar. Além do estimulante uso da internet e dos games educativos, trazendo consigo a necessidade de refletir sobre a relevância da linguagem e uso de recursos digitais nos processos educacionais que nos oferecem com dinâmicas ricas em interatividade.

A linguagem digital interativa está cada vez mais presente em nosso cotidiano e adaptado às escolas, permitem aos alunos que naveguem na multidimensionalidade das representações flexíveis, estabelecendo redes de relações entre os conteúdos e entre membros da comunidade, através dos quais ainda podem participar de processos de aprendizagem colaborativos. Isso se 
comprova com a quantidade de professores que utilizam blogs, redes sociais e outros recursos da web 2.0 como uma nova maneira de abordagem do ensino.

A ideia de interatividade e o uso de conteúdo hipermídia referem-se ao uso de tais ferramentas em sala de aula com a finalidade de envolver ativamente os alunos. O conceito de engajamento, de acordo com Prensky (2008), considera que os estudantes que usarem essas ferramentas vão envolver-se em buscar conhecimento dos temas que estão estudando em vez de serem apenas ouvintes passivos.

É através desse princípio que a produção de conteúdo digital e o desenvolvimento de games educativos se fazem de grande valia para profissionais que demandam materiais pedagógicos mais atuais, como pedagogos, educadores, professores, designers e desenvolvedores, a fim de agregar valor ao complexo e extenso material pedagógico para favorecer tanto a professores como aos alunos, renovando a educação, ao inserir qualitativamente games educativos ao material pedagógico em ambientes de ensino-aprendizagem a fim de estimular e envolver o aluno em seu processo de aprendizado.

\section{Games na educação}

Apesar dos games educativos se adequarem como excelentes ferramentas de aprendizado dentre as diversas opções de um ambiente educacional hipermídia por oferecerem motivação conforme demonstrado pela teoria de fluxo, Van Eck (2009) ressalva que se criou alguma resistência aos games desenvolvidos em décadas passadas. Pelo fato de terem sido criados por acadêmicos que tinham pouco ou nenhum entendimento de arte, ciência e cultura de game design. Esses games eram ferramentas de aprendizado, mas não eram necessariamente jogos digitais. Essa questão nos alerta para que tenhamos compreensão da sinergia necessária entre a pedagogia e a tecnologia para que possamos desenvolver, de fato, games educativos.

A importância do uso da tecnologia da informação e comunicação na educação vai ao encontro do trabalho de Papert (1994), matemático americano criador da linguagem LOGOS, ao observar que o levantamento dos benefícios proporcionados por jogos eletrônicos, em contextos educativos, condiciona-se à sua capacidade de atração muito expressiva sobre crianças e adolescentes, desde a década de 1970 com a expansão desse fenômeno. Percebendo isso, a partir da 
década seguinte, muitos educadores e estudiosos passam a defender o aproveitamento desse recurso como ferramenta de ensino.

Os games têm o elemento visual dinâmico da televisão, mas também são interativos. O que acontece na tela não é inteiramente determinado pelo computador; também é influenciado pelas ações do jogador.

Os estudantes dispõem de um determinado número de horas no seu dia-adia na qual se envolvem com ferramentas interativas ou não. Entretanto, essas ferramentas podem ser acessadas tanto dentro como fora da sala de aula com a finalidade de envolver ativamente os alunos no processo de ensino-aprendizagem. Na maioria das escolas brasileiras, em que a relação aluno-computador não é de um para um, é recomendável que os games e outras atividades instrucionais sejam ofertadas como atividades complementares ou “deveres-de-casa”.

Embora games de entretenimento como Angry Birds ou Roller Coaster Tycoon que não demandam que os alunos façam cálculos de física, contém os princípios do conhecimento que certamente estão presentes no jogo se tratando de um aprendizado tangencial. Aprendizado esse, de acordo com Mattar (2010), que não é o que o aluno aprende diretamente, mas o que aprende ao ser exposto às coisas, em um contexto no qual o jogador fica envolvido. A fim de estabelecerem todas essas conexões é necessário fomentar a interdisciplinaridade para o sucesso dos games como ferramenta de ensino (os diagramas a seguir são baseados nos estudos de Findeli (2001) apresentados no cap.3.2 dessa pesquisa).
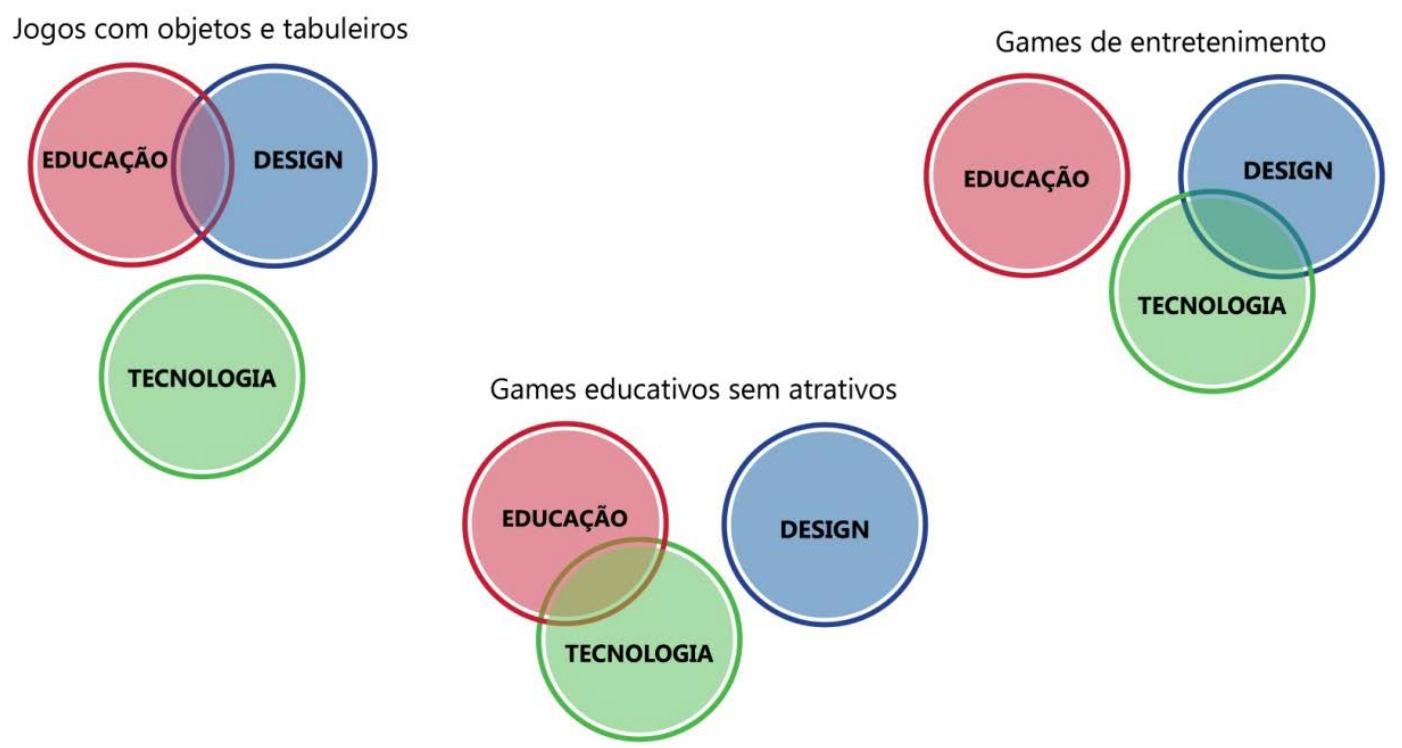

Diagrama 13. Combinações entre os campos da educação, design e tecnologia Fonte: $\mathrm{O}$ autor 


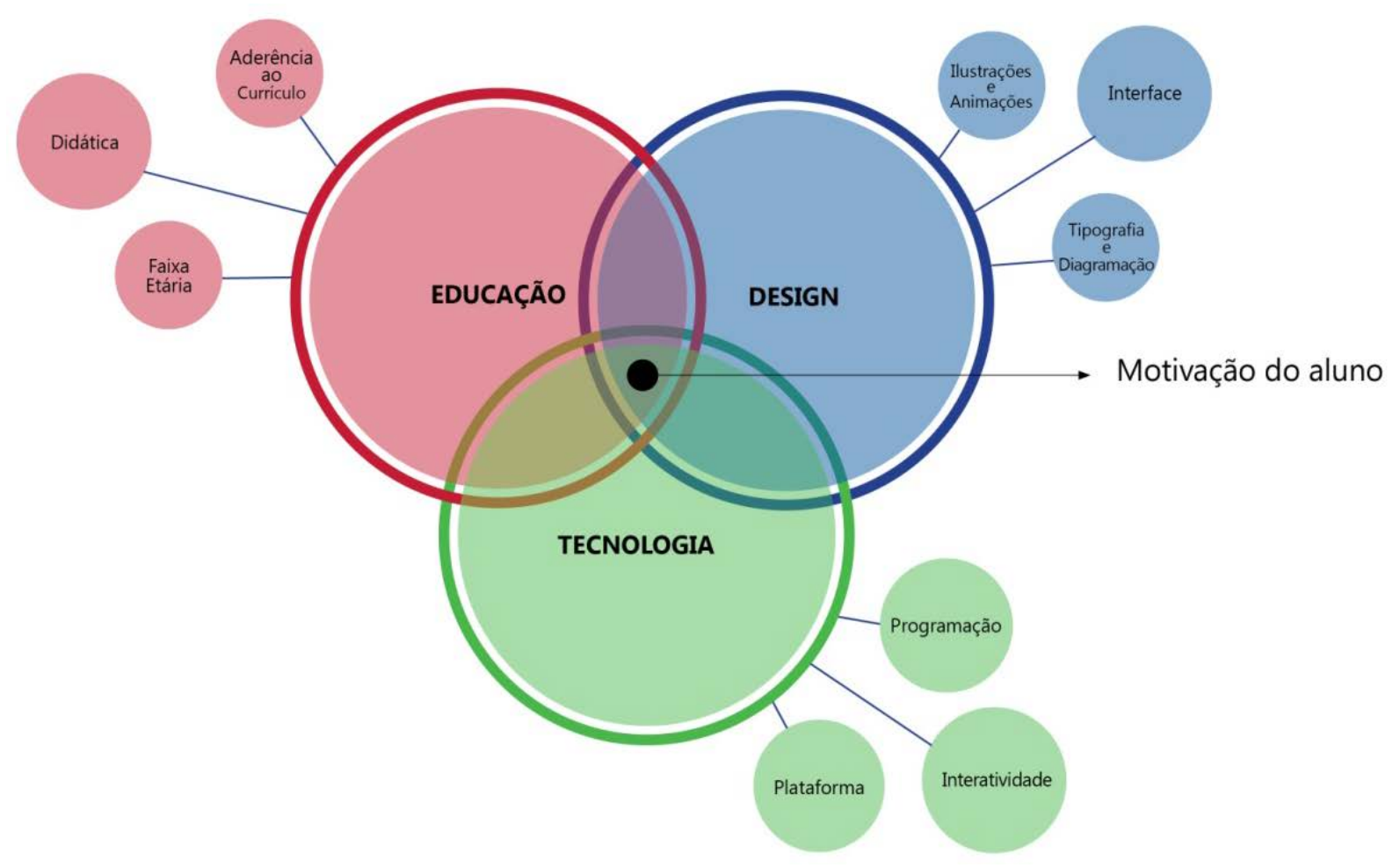

Diagrama 14. Resultado da conjunção dos campos da educação, design e tecnologia Fonte: $\mathrm{O}$ autor

Resultado da conjunção entre os campos da educação, design e tecnologia (Diagrama 8), os games educativos podem se apresentar como excelentes objetos de aprendizagem por proporcionarem um estado de fluxo ao jogador-estudante, no sentido de que o aluno se sente motivado e com atenção total voltada para a atividade (ver capítulo 3.3).

De acordo com o designer instrucional brasileiro João Mattar (2010), no caso do jogador, ao mesmo tempo em que ele fica em estado de fluxo, também exercita o seu senso crítico (porque está assumindo múltiplas perspectivas dentro do game). Portanto, devemos oferecer aos nossos estudantes games pedagógicos e outras ferramentas interativas como atividades complementares, a fim de desenvolver suas habilidades e competências educacionais. Entretanto, se essas atividades educacionais não os mantiverem no canal de fluxo, os perderemos para nossos “concorrentes" diretos, como a TV e games de entretenimento.

Games são eficientes não pelo o que eles são, mas pelo o que eles incorporam e o que os aprendizes fazem ao jogar os games. (Prensky, 2010, p.28) 
Precisamos proporcionar mais envolvimento e engajamento do aluno no processo de seu aprendizado. E o game educativo pode oferecer tais possibilidades de conexão. É sempre bom lembrar que eles não são criados e desenvolvidos somente para entreter o aluno, mas para proporcionar aprendizado e desenvolvimento de determinadas habilidades.

Contudo, os games exigem a capacidade de coordenar informação visual proveniente de múltiplas perspectivas. Esta é uma habilidade enfatizada na descrição do desenvolvimento intelectual, feita por Piaget.

Para melhor entender o potencial pedagógico dos games, compete considerá-lo mais uma vez na condição de jogo. Na perspectiva de Vygotsky (1998), o jogo pode proporcionar ações cognitivas capazes de impulsionar o indivíduo a criar formas ordenadas, regras do coletivo e situações imaginárias. Assim, o jogo permite o entendimento e a exploração da realidade por meio do aprendizado e do desenvolvimento do indivíduo.

O jogo corresponde a um recurso fundamental no processo de desenvolvimento humano, pois, segundo Piaget (1975), se trata de uma atividade lúdica que facilitam o processo de conhecimento, visto que a aprendizagem ocorre por meio de ações. Huizinga (2007) descreve essa ação lúdica como algo que transcende os limites da atividade instintiva do ser humano (seja física ou biológica), já que possui uma função significante, pois “todo jogo significa alguma coisa”. Se um game é percebido como uma forma muito efetiva para se aprender algo, então os estudantes irão se motivar para usá-lo em seu aprendizado, não simplesmente porque é um jogo.

Precisamos preparar os alunos do séc. XXI para um futuro desconhecido e de um grande avanço nas ciências e na tecnologia, no qual eles sobreviverão não por causa do que sabem, mas por causa de suas habilidades.

Para tal desafio, é necessário que uma equipe de profissionais especializados projete, crie e desenvolva os games. E como parte dessa equipe, é fundamental o papel do designer que tenha um entendimento em tecnologia e educação para contribuir para esse processo multidisciplinar, assumindo o papel de ponte entre o especialista pedagógico e o programador para dar forma a games educativos. 


\section{Design de games}

Com as vastas possibilidades para o uso das tecnologias, existe no momento um abismo entre a maturidade alcançada pelos meios tecnológicos e a imaturidade conceitual sobre como e com que objetivo os novos meios de informação e comunicação poderão ser utilizados no contexto da prática educativa. Portugal (2013) enfatiza que o desafio do designer está em descobrir, no espaço do processo de ensino-aprendizagem, as possibilidades de interação que podem ocorrer na relação entre professores, alunos, informações e conhecimentos.

Para o desenvolvimento de um projeto educacional hipermídia, segundo Portugal, o design deve estar atento para o visual, o sonoro, o tátil e o sinestésico, que devem estar presentes de acordo com os objetivos e as características dos usuários a que se destina o projeto. Bonsiepe (1997) ressalta que uma das características da hipermídia, que a torna interessante, é a interação dialógica do meio visual com o discursivo. Nela, a informação pode vir sob a forma de texto, áudio, imagens, sequências de vídeos, animações, músicas e sons. Entretanto essas formas devem ser elaboradas dentro do processo de desenvolvimento de uma interface. Esse processo de mediação entre a fonte e o receptor está diretamente associado à forma de apresentação dos conhecimentos, que deveria ser uma tarefa do design. E conforme o desenvolvedor na área de tecnologias WEB, Jesse James Garret, ele reforça que o design precisa estar centrado nas demandas do usuário.

Azevedo (2012), designer brasileiro, comenta que assim como outros profissionais, o designer da primeira metade do século XX se transformou, deixou de ser um profissional individualista voltado para os juízos estéticos, tornando-se um protagonista interdisciplinar que passa a ser um elo entre os diversos atores de uma equipe.

De forma coerente, podemos atribuir a responsabilidade ao design como mediador entre o ambiente hipermídia e o material pedagógico. Enfatizando o papel do designer como agente multidisciplinar, e o convocando a ampliar o alcance de suas tarefas para além de seu envolvimento no final do processo de uma criação. Além da diversidade do perfil de profissionais envolvidos no processo, Portugal defende que a própria educação, consequentemente, todo o seu material de apoio pedagógico deve ser construído desde múltiplas perspectivas para fomentar o pensamento crítico, a aceitação e a tolerância da diferença, 
propiciando o exercício da ação democrática e uma reavaliação de nossas responsabilidades ecológicas, educacionais e sociais.

\section{3}

\section{Design: a simples complexa interface}

Por onde começar, quando pesquisamos sobre a essência do design? São tantos os questionamentos em torno de design, que um ponto positivo é a geração de críticas reflexivas sobre o seu campo de atuação e as responsabilidades do design contemporâneo, muitas vezes pouco debatidos. Como diria Flusser (2008, p.12), “o fato de começarmos a fazer perguntas é motivo de esperança”. Esse filósofo tcheco e naturalizado brasileiro, desconstrói a palavra design, que em inglês, como substantivo significa, entre outras coisas, "propósito”, "plano”, “conspiração”, “forma”. Entretanto, como verbo - to design - significa, entre outras coisas, "tramar algo”, “simular”, “projetar”, “esquematizar”. E ainda analisando a composição da palavra design, de origem latina, ela contém em si o termo signum. Portanto, etimologicamente, a palavra design significa algo assim como de-signar.

Essas considerações explicam, de certo modo, por que a palavra design, no discurso contemporâneo, pôde tomar uma amplitude e diversidade de seu uso em tão distintas áreas, se distanciando de sua aplicação dos tempos modernos. Além disso, segundo os questionamentos de Flusser, as palavras design, máquina, técnica e arte estão fortemente inter-relacionadas, sendo cada um dos conceitos é impensável sem os demais, além de que todos eles derivam de uma mesma perspectiva existencial diante do mundo. No entanto, essa conexão interna foi negada durante séculos, pelo menos desde a Renascença.

A cultura moderna, burguesa, fez uma separação brusca entre o mundo das artes e o mundo da técnica e das máquinas, de modo que a cultura se dividiu em dois ramos estranhos entre si: por um lado, o ramo científico, quantificável e rígido e por outro ramo estético, qualificador e suave. Flusser extravasa e diz que essa separação desastrosa começou a se tornar insustentável no final do século XIX. A palavra design entrou exatamente nessa brecha como uma espécie de ponte entre esses dois mundos. E isso foi possível porque essa palavra, com sua amplitude, exprime uma conexão entre a técnica e arte, com pesos equivalentes, tornando 
possível uma nova forma de cultura, com isso, se estabelece o desenho industrial (industrial design) no período estruturalista de característica desenvolvimentista, voltado para a produção que, por sua vez, se transforma e, além dos novos sistemas de produção, se criam novos mercados e se identificam diversos perfis de usuários característicos do período pós-estruturalista.

O conceito de design foi então revisto, fragmentado, fundido e recriado, e assim, se desmembrou em diversas possibilidades que justificam diferentes denominações presentes tanto na academia como no mercado. No campo do design existe a contribuição de diversas áreas de conhecimento na elaboração de seus projetos, assim como na formação teórica e prática do designer. Existem diversos conceitos agregados à palavra design como: industrial, gráfico, de produto, de interiores, de moda, de animação, de interface, de games ou simplesmente "design” e para além do campo do design, como o design thinking, o design de serviços, design estratégico, hair design entre outros. O currículo de formação desses profissionais se embasa em teorias do design e práticas de projetos tematizados em relação à sua área de atuação. Bürdek (2010), designer alemão, considera esse processo como uma consequência do atual contexto de desenvolvimento econômico, tecnológico e cultural, os fundamentos históricos, as condições de produção técnica, os fatores ergonômicos ou ecológicos e as exigências artístico-experimentais.

Segundo Papanek (2005), designer e educador austríaco, o planejamento, a modelagem e a padronização de qualquer ação em direção a uma finalidade desejada e previsível é um processo de design. Design é uma atividade consciente que dá uma significativa ordem a algo, também se relaciona aos conceitos de criatividade e inovação, o que faz o sujeito (designer) ser diferente das máquinas.

Apesar de toda essa contextualização para teorizar o campo do design, ele atravessa fronteiras e cria novos paradigmas também no âmbito da vida cotidiana. Isso faz do design um fenômeno que precisa ampliar seu campo de pesquisa para além do técnico e teórico. Papanek (2005) afirma que todos os seres humanos são considerados designers e o design faz parte de todas as atividades humanas. E conceitua o design como um esforço consciente e intuitivo para impor uma ordem significativa. 
Diante disso, Bonsiepe (1997), designer e acadêmico alemão, propõe sete caracterizações para o design, além do referencial da boa forma e das referências sócio- pedagógicas:

1. Design pode se manifestar em qualquer área do conhecimento ou práxis humana, sendo mais amplo que as disciplinas projetuais, incluindo a invenção de novas práticas na vida cotidiana;

2. Design é voltado para o futuro;

3. Design é relacionado à inovação, como palavras que se superpõem mediadas pela ética;

4. Design está particularmente ligado ao espaço retinal, mas não se limita a esse, porque seu conjunto de tarefas inclui compatibilizar os artefatos ao corpo humano;

5. Design visa à ação efetiva, superando denominações como "forma”, “função” e “estilo”, porque diz respeito a critérios de eficiência da ação e ao comportamento social;

6. Design está linguisticamente ancorado no campo dos juízos;

7. Design interage o usuário com o artefato, como domínio da interface.

Essas caracterizações contribuem para elucidar o design como um campo de atividade, no entanto, enquanto ciência e seu mundo cognitivo e acadêmico, Bonsiepe (2011) alerta que ainda existem perspectivas diferentes entre as atividades científicas e as projetuais, por fim, especulando que no futuro, o ensino do Design será uma disciplina básica que deve ser ofertada a todas as disciplinas científicas. Afinal, seu campo de atividade tem se ampliado e influenciado as mais diversas áreas.

\section{Ético, estético, técnico... ou prático}

No campo do design existe a contribuição de diversas áreas de conhecimento na elaboração de seus projetos, assim como na formação teórica e prática do designer. No entanto, nos limites da teoria disciplinar e interdisciplinar do design acontecem certas divergências.

Papanek (2005) se apropria do questionamento dos alunos para expor uma questão paradoxal sobre o design, quando perguntam a ele se devem desenvolver 
um projeto para ser funcional ou para ser esteticamente atraente. O professor enfatiza que esse é o questionamento mais ouvido, mais compreensível e mais equivocado no design de hoje. "Você quer que o produto seja bonito ou que funcione?” E responde aos alunos que é muito simples: o valor estético é parte da herança de sua funcionalidade.

E continua ao dizer que os Indivíduos da comunidade “civilizada” dependem das mãos, do cérebro e da imaginação dos especialistas. Mas, apesar do quão bem treinados esses especialistas devem ser, ao menos eles deveriam ter um senso de ética, intelecto e responsabilidade artística, pois se acometerem valores contrários a esses, a moralidade, a inteligência, a beleza e a elegância da qualidade de vida sofrerão, em imensuráveis proporções, devido ao sistema atual da produção em massa e do capital privado.

Tanto Foster (2011) como Flusser (2007), de maneiras distintas, vem reforçar o cuidado com esses valores, ao apresentarem uma crítica ao Design contemporâneo e abrem espaço para uma reflexão mais profunda sobre os modos de atuação e a responsabilidade no design. Isso porque, sendo atividade projetual, o design tem como escopo o desenvolvimento e a criação de objetos que, de alguma maneira, implicam na vida cotidiana das pessoas e no seu entorno. No entanto, muitas vezes, o impacto de um projeto é muito maior do que seu projetista consegue imaginar.

Deforges (1994) também enfatiza as responsabilidades do profissional, afinal o designer quer se distinguir do engenheiro tradicional (ou se o engenheiro quiser se declarar designer), ele precisa, além dos saberes e atitudes evocadas anteriormente, estar imbuído de uma ideologia, seja ela qual for, a mais forte possível. Essa ideia de gerar corretamente os recursos não é nova: já se encontra nos economistas fisiocratras do século XVIII e na tecno-economia no século XIX. Entretanto, as ideias em torno de estarmos em um mundo finito não era considerada, na época, como uma limitação porque os limites eram remetidos... ao infinito.

A necessidade de investigarmos áreas de conhecimento relacionadas ao design torna-se cada vez mais relevante, pois como alerta Bonsiepe (2011), o campo do design perdeu a sua substância quando passou a tratar das superficialidades, colocando-se a serviço da beleza cosmética e visando alcançar os lucros do mercado de uma maneira fácil. 
Partindo de uma comparação entre o Art Nouveau e o Design Contemporâneo, Foster (2011) critica ambos os movimentos pela supervalorização da estética como diferencial dos produtos, afirmando que esse velho debate ganha uma nova ressonância nos dias de hoje, quando o estético e o utilitário não estão somente fundidos, mas quase totalmente subsumidos no comercial e tudo - não apenas projetos arquitetônicos e exposições de arte, mas tudo, de jeans a genes - parece ser considerado como design.

Ao longo da história, a configuração de objetos de uso teve três fases características, definidas de acordo com os princípios teóricos que fundamentam a praxis e os meios utilizados para a produção dos objetos. Em um primeiro momento a maestria dos artesãos, a tradição das corporações de ofício e a arte dominaram a produção artesanal de objetos únicos. Posteriormente, com o desenvolvimento das manufaturas e a produção de pequenas séries de produtos, foram criadas as primeiras academias de arte "schools of design" - onde se qualificava pessoal para a criação de formas, segundo princípios técnicos e normas de sucessivos estilos artísticos. Finalmente, com a industrialização da produção, a arte foi substituída pela Ciência como fundamento no processo de configuração.

Nesse contexto, Couto (2009) sintetiza ao afirmar que existe uma expectativa para que o designer atue mais do que faça. Em termos filosóficos, alguém diria que o designer deve ser mais voltado a questões práticas e não a instrumentais, e que seu foco seja ético, não tecnológico. Em termos existencialistas, a responsabilidade do design significa que os designers sempre devem estar conscientes do fato de que toda vez que eles se envolverem com um projeto de design, eles de certa forma, recriam o mundo.

E para se preparar a tal responsabilidade, Bonsiepe (2010) sugere que o campo do Design seja tratado como qualquer outra disciplina consolidada da ciência e invista em pesquisa, o que permitiria a geração de conhecimentos e a formação de um sólido conjunto de dados para os estudos da área. Isso demanda a troca de informações e envolvimento com outras áreas do conhecimento conduzindo o design a ampliar sua importância e relevância no mundo, constituindo-se como uma atividade preferencialmente interdisciplinar. 


\section{A interdisciplinaridade do design}

Uma vez entendido o Design como uma disciplina nova, nascida da união de áreas diversas de conhecimentos, cuja prática se caracteriza pelo relacionamento com outras disciplinas, convém a ele que sejam identificadas quaisquer possibilidades de ampliação e fundamentação de seus métodos e teorias. E Couto (1997) nos direciona a confiar no processo pelo qual o design precisa se moldar em relação a outras áreas:

A interdisciplinaridade não é apenas um modismo. É uma forma de superação da divisão entre o domínio do pensamento teórico e da ação informada. Convém salientar que os problemas concernentes ao confronto, a aproximação e a possível integração de múltiplos domínios da atividade humana, não se colocam apenas no plano do conhecimento ou da teorização, mas também, e talvez, sobretudo, do domínio da ação ou da intervenção efetiva no campo da realidade social e humana. (COUTO, 1997, p.39).

Isso não é um processo simples e, por isso, se faz inovador. E como nos traz Bonsiepe (2010), a inovação é a palavra-chave da época atual. Ela caracteriza a dinâmica da sociedade industrial. É quase um imperativo, se bem que seria errado objetivá-la, pois depende dos investimentos feitos para criar inovação em larga escala, nesse ponto, os países periféricos se distanciam pela falta de recursos financeiros.

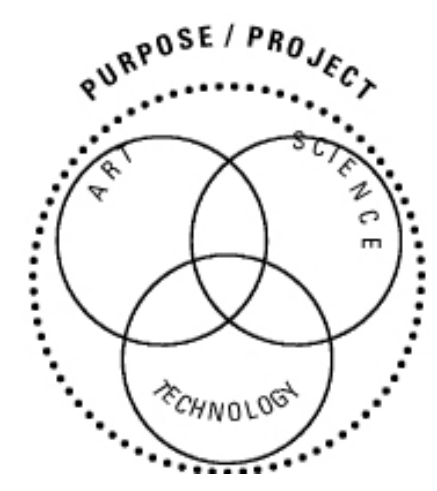

Diagrama 15.

Interdisciplinaridade: arte, ciências e tecnologia Fonte: Findeli (2001)
Findeli (2001) consegue representar no diagrama 9, o que seria a ótima, porém hipotética, estrutura para o currículo a ser aplicado na tradição da Bauhaus.

Entretanto, segundo o acadêmico canadense, as estruturas que compuseram os estudos, tanto da Bauhaus como de cada uma das representativas escolas de Design, se desconectaram de um desses três propósitos. Como Findeli nos mostra a seguir no diagrama 10 : 


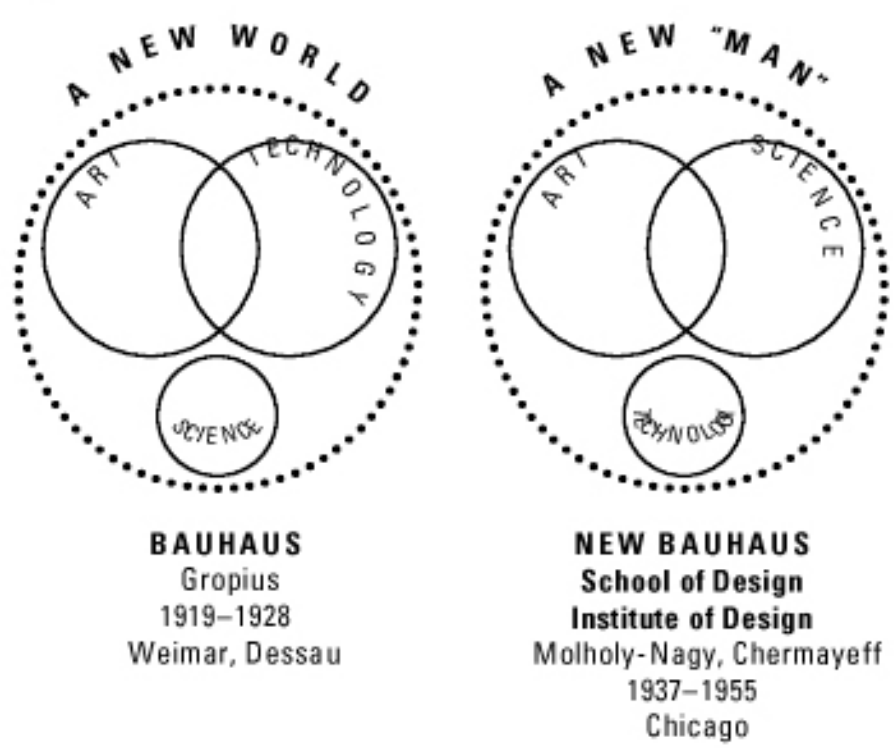

Diagrama 16. Novo Mundo, Novo Homem e Nova Cultura

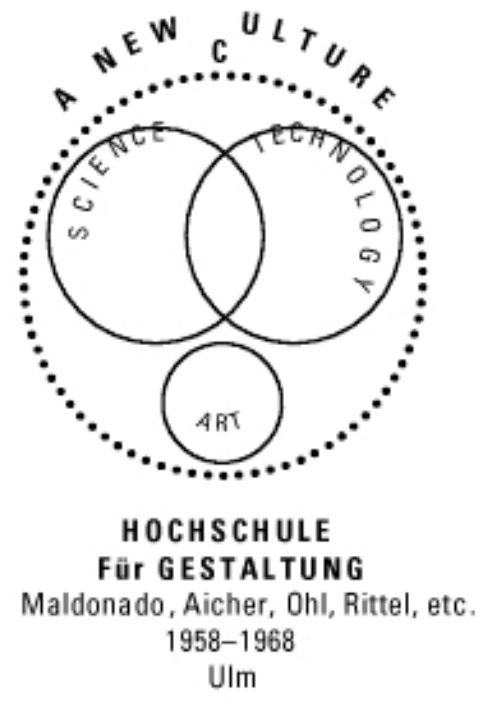

Fonte: Findeli (2001)

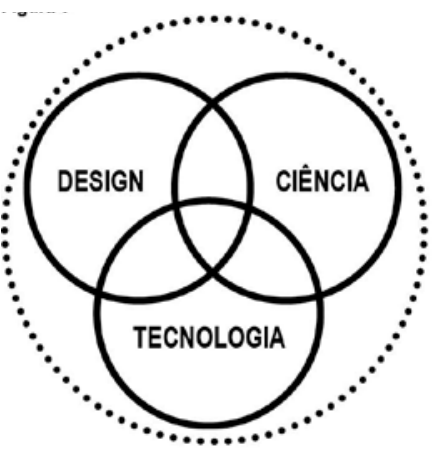

Diagrama 17. Interdisciplinaridade: design, ciências e tecnologia Fonte: Findeli (2001)
Contudo, a ciência está inserida num sistema no qual a tecnologia e o design ocupam papéis não menos importantes. Para fundamentar essa asserção analisaremos as interações entre três tipos de inovação: na ciência, na tecnologia e no design, como no diagrama 11.

Geralmente, a solução de problemas complexos extrapola a esfera de competência de um único campo do conhecimento. O tratamento de tais problemas requer a união de vários especialistas. É nesse nicho que o Design, como tecnologia que é, pode melhor aproveitar a sua vocação interdisciplinar.

Para Bomfim (1994) o designer, no entanto, não se relaciona imediatamente a nenhuma filosofia, ciência ou arte em particular, ao contrário, sendo atividade interdisciplinar, busca fundamentos na tecnologia e ciências, tornando-se necessário o desenvolvimento de linguagens e códigos que promovam a comunicação entre especialistas na produção de conhecimentos, e destes com os que se dedicam à aplicação dos conhecimentos na práxis, ou seja, a interação dos que sabem com os que fazem. 
Provavelmente existe um consenso de que a ciência e a tecnologia estão concatenadas, se bem que não se pode afirmar que a tecnologia seja uma consequência direta dos investimentos feitos na ciência. Menos claras ainda são a relação entre a ciência e design. A pergunta é: para quê serve o design num instituto de pesquisa científica? Pois o design, longe de ser somente um elemento periférico, é constitutivo para o processo geral da inovação. Segundo Bonsiepe (2010), o processo de inovação passa por diferentes fases - ciência, tecnologia e design.

Quando falta um elo nessa cadeia, a inovação fica sem ressonância econômica e social. Quando se separa a ciência das duas etapas chega-se ao academicismo. Quando separamos a tecnologia das outras duas etapas, chegamos ao tecnocratismo. Quando tratamos o design isoladamente corremos o risco de cair na armadilha do formalismo estético.

O design é o último elemento através do qual a inovação científica e tecnológica vem introduzida na prática da vida cotidiana. Por isso o design contém um considerável potencial quando está integrado aos institutos de pesquisa científica e tecnológica. (Bonsiepe, 2011, p.35)

Na atuação em equipes de projeto geralmente existem diferentes profissões atuando em um projeto que é comum o que confere características interdisciplinares, e ao mesmo tempo, confere características disciplinares porque o designer terá que aplicar seus conhecimentos de prática projetual (processos criativos, organização da informação e pesquisa), semiótica, teoria da forma e cor, e tantos outros que compõem a disciplina de Design.

A interdisciplinaridade no Design acontece devido à contribuição de diferentes áreas que fazem parte do contexto em que o projeto é aplicado ou desenvolvido e conduz a um objeto mais experiente e com um melhor resultado para a sociedade. Dessa maneira, o design exige que o projeto seja feito em conjunto com outras áreas de conhecimento para solucionar um determinado problema diagnosticado em nosso cotidiano. Azevedo (2012), designer brasileiro, comenta que assim como outros profissionais, o designer da primeira metade do século XX vem se transformando. Está deixando de ser um profissional individualista, exclusivamente voltado para os juízos estéticos, para abrir muitas possibilidades quando se coloca na posição de protagonista interdisciplinar ao se passar como um elo entre os diversos atores de uma equipe. 
Entretanto, Foster (2001), questiona e alerta para o tipo de ingerência ou influência que o Design tem praticado no mercado atual, ao afirmar:

Há atualmente uma "inflação do design" devido a três fatores: a) o eterno traçar de perfis da mercadoria, o produto transforma-se num objeto personalizado e autônomo ("mini-eu”) ; b) a importância das embalagens, que têm o papel de atrair a atenção do consumidor e torna-se tão ou mais importante quanto o próprio produto; c) o aumento da centralidade das indústrias de mídia para a economia, que dá aos produtos uma existência mais ampla. (Foster, 2011, p.32)

Vale enfatizar que estamos tratando com vários sistemas inter-relacionados, e sua função e evolução estão de acordo com diferentes lógicas: o técnico ou o mundo feito pelo homem, o mundo biofísico, o mundo social, e o mundo simbólico. Findeli (2007) ressalta que esses mundos internos ou externos interagem uns com os outros. Como consequência, antes que um projeto seja lançado em meio à tão complexa situação, o designer precisa ter certeza da adequada representação de seu conteúdo, da estrutura e da dinâmica evolutiva.

Para Findeli, essa é a razão pelo qual a inteligência visual do futuro é capaz de penetrar no mundo invisível da consciência humana (pensamentos, motivações, propósitos, medos, necessidades, aspirações etc.) e na complexa ecologia do mundo externo. Nesse contexto, o designer precisa ter um conhecimento, entendimento e clareza de quem e como são os indivíduos que irão fazer uso de seu projeto, idéia ou produto e como se estabelecerá a relação entre as partes. É o que veremos a seguir.

\section{A relação do projeto com o usuário}

Essa relação é comentada por Argan (1983), ao descrever que o sujeito pensa o objeto, que por sua vez é projetado. É importante haver entre o objeto e o sujeito uma relação de integração em lugar de haver uma relação de alienação. Estabelecida esta espécie de trindade projeto-objeto-sujeito, pode-se dizer que essa é a trindade de nossa cultura enquanto cultura não dogmática, ou seja, democrática e que não tinha absolutamente o mesmo significado em uma cultura da autoridade e do poder.

O designer e sua atividade, portanto, são confrontados por diferentes culturas e interesses, de acordo com a postura de quem usufrui ou interpreta sua 
ação. Para Löbach (2001) o designer deveria atuar constantemente na defesa dos interesses dos usuários. Todavia, nos últimos tempos, o cliente imediato do designer é o fabricante, sendo que o usuário é o receptor final dos produtos projetados. Contudo, o determinismo da razão instrumental e o fator econômico nos direcionam a considerar o usuário como consumidor, ou melhor, como Findeli o retrata: um serhumano cercado por ergonomia e psicologia cognitiva.

A ergonomia tem como seu principal interlocutor o usuário, consumidor, operador, trabalhador e sempre tratou da comunicação e interação do homem com outro homem, objeto, espaço ou sistema de informação com o objetivo de facilitar o entendimento mútuo. Tanto para uma sinalização ou para um sistema de informação, o uso de pictogramas, ícones, ou mensagens de fácil reconhecimento são fundamentais para a identificação imediata do usuário com a informação. (Moraes, 1992, p. 180)

A experiência do usuário trata de transcender o material, de criar uma experiência através de um dispositivo. Diante do exposto, podemos dizer que apesar da experiência do usuário, torna-se ímpar preocupar-se com os aspectos relativos aos artefatos e sua interação a fim de possibilitar experiências significativas.

Para sistematizar a interatividade do projeto com as suas devidas relações, o planejamento precisa ser eficiente e, para tal, é necessário que se potencialize a relação entre o funcionamento e o uso, indicando o conceito de interface e o processo de Design. Esse conceito tem uma ligação forte com os seres humanos e sua função no uso e no desenvolvimento das atividades profissionais e do cotidiano.

Com a busca de proximidade ao usuário o avanço da tecnologia, podemos acompanhar as mudanças pelas quais o mercado vem passando e têm obrigado os profissionais de diversas áreas a reverem suas estratégias para atender às novas exigências do consumidor. Nesse contexto, eles se vêem forçados a reavaliar as formas tradicionais de abordagem e envolvimento do usuário, priorizando a diferenciação e a inovação como formas de agregar valor aos produtos e serviços para superar a concorrência.

O objetivo de um sistema, em termos de interação humano-computador, reforçam Preece, Rogers, Sharp (2005), é atender necessidades do usuário e, para isso, devem ser especificadas as metas de usabilidade e de experiência (o que fazer e por quais meios). A meta de usabilidade é o fator que assegura que o 
sistema seja fácil de utilizar, eficiente e agradável, da perspectiva do usuário. Quanto a meta de experiência do usuário, está relacionada com o tempo, o surgimento de novas tecnologias e suas possibilidades, aliadas ao aumento das áreas de aplicação (entretenimento, educação etc.).

A tecnologia tem avançado virtuosamente e expandido seus limites a novos produtos para dentro das telas dos monitores de computadores, celulares ou tablets e esta possibilidade compõe um espaço de ação nesses equipamentos. Dessa forma, cabe ao designer projetar os elementos visuais e sua composição que ficarão dispostos, de maneira a compor uma interface com a finalidade de induzir o usuário às ações. Entretanto, para que isso seja viável, torna-se necessário planejar de modo eficiente o processo simbólico de cada elemento, considerando o contexto do produto, o equipamento, o mercado e seu usuário.

\section{A demanda do design de interface}

Entramos, há poucas décadas, na era da informática, e uma nova ruptura se estabeleceu. A sociedade da informação deu uma amplitude ao homem, tem criado novas especializações profissionais e extrapolado os limites das culturas tradicionais. Hoje, com o advento das tecnologias da informação e comunicação conhecemos um novo suporte para a escrita e a leitura, passamos a ler e assistir a conteúdos, dos livros e televisores para as telas do computador e dispositivos móveis. Para Portugal (2012) é um novo modo de lidar com a informação e o conhecimento que invadem o nosso ambiente social, público e educacional, e ainda aliada à internet, possibilitando um campo de comunicação interativo e virtual.

São tamanhas as transformações tecnológicas e suas consequências sociais, éticas, culturais, interação e experiência que, desse fato, torna-se fundamental buscar novos modelos, novos métodos e novas abordagens para o design no contexto da interação. Nesse contexto, o design passou a ter uma função social de tornar os ambientes inteligíveis. Bonsiepe (1997) considera o design como um campo que pode contribuir efetivamente para a produção de interfaces, estas, por sua vez, são os elementos de transposição do usuário para as ferramentas tecnológicas, que viabilizam as interações e experiências, aspectos importantes no desenvolvimento cognitivo e sensorial do ser-humano. 
Um conceito de design digital é proposto por Bonsiepe (1997) com a ideia de que seu domínio é a "interface”, um sistema que faz interagir o usuário e o artefato em função de uma tarefa. Isso estabelece uma tríade, porque há um usuário que pretende realizar uma tarefa; há também a tarefa proposta e, ainda, uma ferramenta ou artefato para efetivar sua execução. O processo de mediação entre essas três instâncias é denominado interface, as características do produto resultante são previstas e determinadas na interação entre o caráter do artefato, da tarefa e do usuário.

Para uma efetiva interação em um ambiente digital interativo, Bonsiepe (2011) explica que se usam diferentes canais de percepção (visual, auditivo, tátil) e novos procedimentos para apresentar a informação, nas educativas ou científicas. Lidar com esses múltiplos recursos - música, imagens, animação, texto - requer múltiplas competências, até daquelas meramente discursivas que dificilmente encontram-se reunidas em um só profissional. Isso requer trabalho em equipe com especialistas em psicologia cognitiva, música, redação, fotografia, ilustração, programação, animação, design de interface entre outros. Estas colaborações multidisciplinares são características do design digital, que atuam em uma dinâmica não-linear, de interconectividade, em redes e muito dinâmica compondo o ambiente hipermídia.

Contudo, Mattar (2010) afirma que a tecnologia da informação e comunicação caracteriza-se como uma nova tecnologia intelectual, que nos permite potencializar não apenas nossa memória, mas também diferentes formas de raciocínio. Essa mudança têm sido aplicada na organização e na produção de conhecimento e tem criado a base de uma nova sociedade, na qual o saber passa a ser entendido como o produto de negociações coletivas que envolvem pessoas e artefatos tecnológicos. Para Bonsiepe (1997) as relações discursivas se fazem cada vez mais visuais e os símbolos e ícones estão se tornando, cada vez mais, como forma de discurso. Neles, a informação pode tanto vir na forma de texto como de imagens, música, sequência de vídeos e animações.

Entretanto, essas formas precisam ser elaboradas dentro de um processo de desenvolvimento de uma interface, em que as possibilidades abertas pela tecnologia de informação e comunicação estarão ou não disponíveis, pois, segundo Bonsiepe (2011), dependerá da qualidade da interface para que haja uma efetiva comunicação entre o produto/serviço e o usuário. Esse processo de 
mediação está diretamente associado à forma de apresentação dos conhecimentos que deve ser uma tarefa central do design.

Quais são os modos de interação? Qual é o feedback? A interface está organizada em zonas funcionais? Quais e porque? Como são hierarquizadas e diferenciadas? Quais tipologias e cores contribuem para uma melhor leitura digital? Atribuir funções a cada uma dessas cores? Acrescentar sons? A interface está coerente com o seu propósito? Está coerente com o seu conteúdo, serviço e usuário?

Todas essas questões fazem com que o design de interfaces se torne uma recente área de trabalho profissional. Na ciência da computação em geral o papel do design da interface era subestimado como cosmética. De acordo com o paradigma dominante, a interface de usuário humano para software é um meio através do qual as pessoas e o computador se comunicam. Segundo Myers/Rosson (1992), a preocupação com a interface não pode ser mais considerada só uma questão de cosmética, afinal nos últimos anos, em geral, 48\% do trabalho da programação foi dedicado a interface.

Com o advento da globalização, a utilização de ferramentas e produtos digitais cruzaram fronteiras e são amplamente utilizados em todo o mundo, desenvolveram-se códigos de comunicação à parte do idioma local. E essa transformação foi percebida pelos designers de interface que tornaram a linguagem icônica um meio de comunicação eficaz em seus projetos. Além de que, distinta de um material impresso, uma interface digital não é lida linearmente, mas utilizada através de buscas, atalhos e seleções com seus menus, navegação, hipertextos e imagens.

A tarefa de conceber e desenvolver a interface de um ambiente hipermidiático, de acordo com os estudos de Portugal (2013), é uma atribuição do designer gráfico, que é o profissional dotado de tal competência. Entretanto, ela deve atender a todas as condicionantes e restrições definidas pelo conjunto de profissionais da equipe.

Para que essa funcionalidade da interface seja eficaz, é crucial conhecer bem o usuário e sua forma de interagir com o sistema através de seus elementos digitais, possibilitando a apresentação e o uso das informações através das interfaces. Podemos dizer que o usuário aprende a manipular a interface até que ela se torne transparente, de tal maneira que possa "esquecê-la" a ponto de intuir os seus 
comandos e ferramentas ao utilizar o produto digital e virtual. A evolução das TICs e, consequentemente, o desenvolvimento de suas interfaces têm gerado novos paradigmas e o universo digital nos têm proporcionado constantes descobertas.

Ao tratar de novos paradigmas, extrapolamos a esfera de competência de um único campo do conhecimento. Assim, o tratamento de tais problemas requer a união de vários especialistas. É nesse nicho que o Design, como tecnologia que é, pode melhor aproveitar a sua vocação interdisciplinar. Papanek (2005) comenta que o designer deve ser o responsável por um esforço consciente para por uma ordem a um significado. E para tal ordem, ele terá que aplicar seus conhecimentos de prática projetual (processos criativos, organização da informação e pesquisa) entre tantos outros que compõem a disciplina de Design. Suas atividades são relacionadas aos conceitos de criatividade e que o faz ser bem diferente das máquinas.

Com o desenvolvimento das tecnologias de informação e comunicação se estabeleceu um novo paradigma tecnológico, o do universo digital que vai além da linearidade dos livros e do audiovisual. Assim, é através da "interface” que nos comunicamos com esse universo, e o designer tornou-se o seu mediador. E, além disso, ao tratar de games educativos, é necessário que o designer também se preocupe com questões psíquicas de comportamento, envolvimento, interesse e estímulos ao aluno, como veremos a seguir.

\section{3}

\section{MOTIVAÇÃO: obtendo o estado de "fluxo" no aprendizado}

Professores sabem bem que alguns dos desafios no ambiente escolar envolvem suscitar a atenção e a motivação dos alunos. Queixas de desinteresse são comuns, de maneira que até o professor também pode perder a motivação em seu ofício, ao perceber que seu trabalho não satisfaz suas expectativas - quando ainda as têm. Cenários como esses são fruto de adversidades sociais, econômicas, culturais, políticas, e demais aspectos conjunturais que prejudicam o estado da educação escolar.

Devemos mesclar de forma criativa a pedagogia com a tecnologia e criar ambientes de aprendizagem inovadores, com soluções que empoderem o professor e envolva os alunos. Para o educador e game designer americano Marc Prensky 
(2008), o papel da tecnologia, dentro e fora da sala de aula, é o de oferecer suporte ao novo paradigma de ensino.

Em torno desse paradigma, entre o nível de desenvolvimento e o desafio alcançável, é que demonstraremos as pesquisas do estado de fluxo que Mihaly Csikszentmihalyi (1988), psicólogo ítalo-húngaro, que nos tem surpreendido ao pesquisar esse tema, desde a década de 1970 .

\section{Criando a experiência ideal (optimal experience)}

Csikszentmihalyi (1988) faz uso do termo de “experiência ideal” para descrever as ocasiões em que sentimos uma sensação de exaltação ou uma profunda sensação de diversão, a qual nos acalenta por um bom tempo e tornamse marcantes em nossas vidas.

Estar em estado ideal é resultante de quando há ordem em nossa consciência. Isso acontece quando estamos focados em metas bem definidas e nossas habilidades estão alinhadas com as oportunidades de ação.

O elemento chave da experiência ideal é que ela termina nela mesma. Ela pode ser empreendida por muitas razões, mas a atividade em breve se tornará intrinsecamente recompensadora. Isso é autotélico, e uma experiência autotélica eleva a vida a um nível diferente.

\section{A experiência autotélica}

A atividade é considerada autotélica quando requer energia por parte da pessoa, e fornece pouca ou nenhuma recompensa convencional. A palavra "autotélica" é derivada do Grego: “auto” quer dizer “em si”, e “telos” significa “meta”, finalidade e propósito”. (CSIKZENTMIHALYI, 1975, 1990; JACSON; EKLUND, 2004).

O autor distinguiu o estado de fluxo em relação a experiência autotélica, isto é, uma experiência para ser autotélica, implicitamente assume que não há nenhum objetivo ou recompensa externa, tal suposição não é necessária para estabelecer um canal de fluxo. Portanto, esta dimensão é descrita como consequência ou resultado final de todas as outras oito dimensões do fluxo.

Refere-se a uma atividade que é realizada sem nenhuma expectativa de benefícios futuros, mas simplesmente porque a própria execução da atividade é 
recompensadora. Desta forma, o que diferencia a atividade autotélica é que a pessoa foca a atenção na própria atividade e não em suas consequências.

Tanto a experiência autotélica como o estado de fluxo, elevam o curso da vida a um nível diferente. A alienação dá lugar ao envolvimento, a satisfação substitui o tédio, o desamparo e impotência dão lugar a um sentimento de controle, e a energia psíquica trabalha para reforçar o sentido do self, ao invés de se perder a serviço de metas externas.

Quando a experiência é intrinsecamente compensadora é justificada no presente, ao invés de ser refém de um hipotético ganho futuro. (CSIKSZENTMIHALYI, 1990).

\section{Pesquisando o fluxo}

O autor fez os seus primeiros estudos neste domínio, desde os anos 1970, tentando compreender a natureza destas experiências subjetivas por parte de algumas centenas de artistas, atletas, cirurgiões, campeões de xadrez, entre outros. Os entrevistados relataram como se sentiam ao realizar as tarefas que lhes davam mais prazer, é esse entendimento que dá origem ao desenvolvimento da teoria da experiência ideal, com base no conceito de fluxo - um estado no qual os indivíduos estão tão envolvidos numa atividade que nada mais parece importar; uma experiência em si tão satisfatória que os indivíduos estão prontos a pagar qualquer preço para poderem realizá-la. A partir do desenvolvimento de um método destinado a medir a qualidade da experiência subjetiva (Experience Sampling Method - ESM), Csikszentmihalyi (1975) e os seus colaboradores da Universidade de Chicago estudaram, ao longo das últimas décadas, o conteúdo das experiências ideais relatadas por milhares de homens e mulheres de todo o mundo.

Este instrumento teve como procedimento exigir que os pesquisados utilizassem um pager ou um cronômetro eletrônico programável por uma semana, e que respondessem a todos os sinais do pager preenchendo duas páginas de um livreto de respostas. Os pagers eram ativados por sinais enviados aleatoriamente durante o dia, de modo que a maioria dos pesquisados preencheram cerca de cinquenta respostas durante a semana, fornecendo um registro de funcionamento do que fizeram e como se sentiram em situações típicas da vida cotidiana. 
A forma de mensurar o fluxo através do ESM foi através da visualização do padrão de duas respostas: o desafio que a pessoa que está enfrentando no momento do sinal, e as habilidades que a pessoa percebe possuir neste momento - cada um deles avaliado em uma escala de dez pontos. Quando ambos, desafios e habilidades estão classificados acima da média da pessoa, dizemos que a pessoa está em fluxo. Se ambas as variáveis estão abaixo da média, a pessoa é considerada em estado de apatia (ver quadros da página seguinte). Se o desafio é avaliado acima da média, enquanto a habilidade é avaliada abaixo, a situação é de ansiedade. Na situação inversa, o desafio de baixa e a habilidade alta, o estado de consciência que se configura é denominado tédio. (CSIKSZENTMIHALYI, 1993).

Contudo, o autor apresenta um exemplo de sucesso que surpreendeu a todos pelo engajamento da comunidade mundial, o software Linux, onde dezenas de milhares de programadores amadores e profissionais trabalharam arduamente na criação, desenvolvimento e testes do software, seja para se deleitar em resolver problemas de concepção e programação ou para ser reconhecido por seus respeitáveis colegas. O Linux foi produzido para competir com concorrentes formidáveis como a Microsoft, a qual necessita pagar seus programadores. Esse é um ótimo exemplo de uma crescente recompensa intrínseca ao mesmo tempo em que se apresenta com uma recompensa extrínseca, propiciando a todos aqueles que contribuíram para esse projeto em um estado de fluxo.

\section{Entendendo o fluxo}

Em estado de fluxo, o indivíduo é desafiado a dar o melhor de si, e precisa constantemente aperfeiçoar suas habilidades. Em fluxo, ele não tem a oportunidade de refletir sobre o self - se ele permitisse tornar-se autoconsciente, a experiência talvez não fosse tão profunda. Mas depois, quando a atividade termina e a autoconsciência tem a oportunidade de retornar, o self sobre o qual a pessoa reflete não é o mesmo self que existia antes da experiência de fluxo.

No dia-a-dia, as experiências de fluxo são relativamente raras, mas em quase tudo - trabalhos, estudos, hobbies, rituais - é possível vivenciá-las. É um estado de total engajamento em uma determinada atividade que, embora possa ser exigente ou até mesmo estressante enquanto você a está realizando, mas se houver suficiente habilidade 
para efetuar a tarefa nos manteremos no canal de fluxo como mostra o diagrama 12, oferece posteriormente um profundo senso de satisfação.
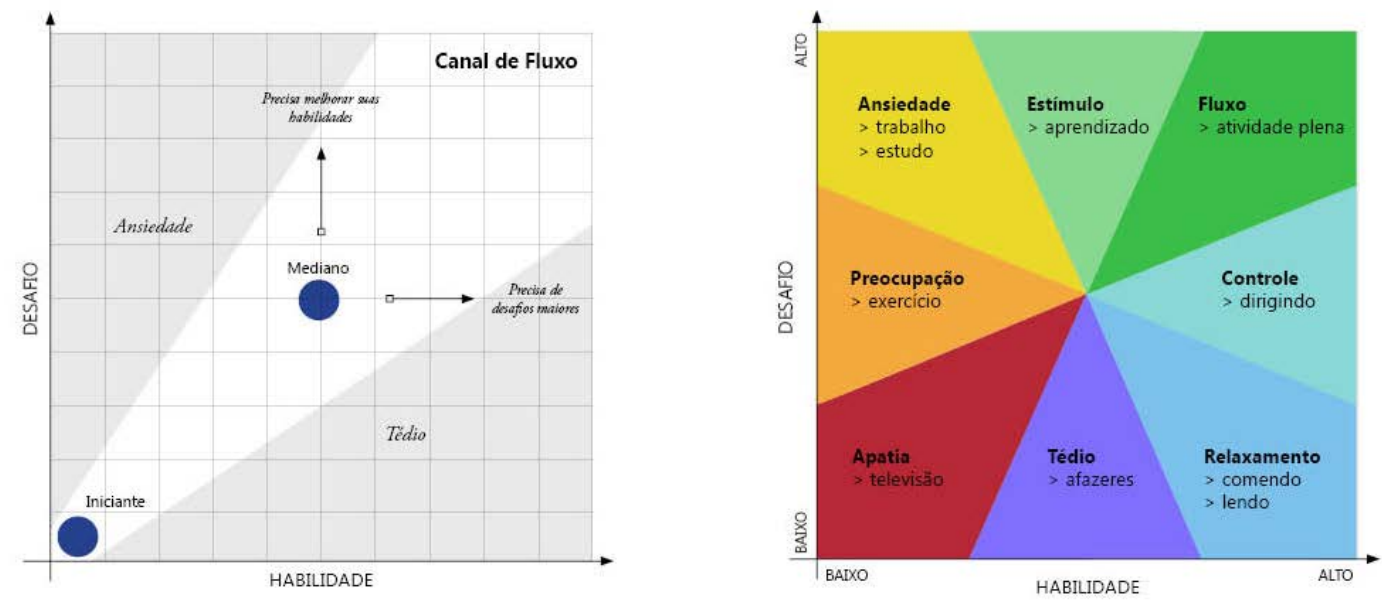

Diagrama 18. Canal de Fluxo: O primeiro quadro, a representação no canal de fluxo de um praticante iniciante e outro mediano e, o segundo, os sentimentos demonstrados pelos indivíduos na relação entre a dificuldade do desafio e a qualidade da habilidade Fonte: Csikszentmihalyi (1993)

Os estudos sobre o fluxo apontam para uma característica comum: a experiência de fluxo proporciona um sentimento de descoberta, um sentimento criativo de transportar a pessoa para uma nova realidade. Proporciona um impulso para que a pessoa alcance níveis mais altos de desempenho, e a conduz a estados de consciência jamais sonhados.

Em suma, ele transforma o self tornando-o mais complexo. Além de gerar outra consequência, frequentemente mencionada no fluxo, que é a elevação da performance. Grandes atletas em geral atingem o fluxo durante seus treinamentos e competições, caso contrário eles não conseguiriam se impulsionar até os seus limites.

Pesquisas demonstram que o fluxo ocorre durante a performance máxima, e que os atletas são motivados a fazer o seu melhor para experimentar o fluxo novamente. Obviamente, não são apenas os grandes esportistas que vivenciam o fluxo e são impulsionados por ele; qualquer um pode entrar neste estado quando está “fazendo o seu melhor”. (CSIKSZENTMIHALYI, 1993). 


\section{Produção, responsabilidade e lazer}

Csikszentmihalyi (1999) procura nos conduzir a uma melhor compreensão sobre o fluxo ao classificar o tipo de atividades que praticamos em nosso dia-a-dia. Ele as divide em três tipos:

1. Atividades produtivas (trabalho, estudo, hobbie);

2. Atividades de manutenção (alimentação, cuidados pessoais e casa, transporte); e

3. Atividades de lazer (consumo de mídia, hobbies, conversas, repouso).

São essas três atividades que absorvem nossa energia psíquica, e sobre as quais mantemos nossa atenção. Atualmente a TV e os games ocupam a maior quantidade de energia psíquica de todos os atos de lazer.

O lazer potencializa a qualidade de vida ajudando a manter a ordem, porém não cria uma nova ordem no consciente. Já a diversão, normalmente está alinhada a expectativa de um indivíduo, mas pode surpreender além do que tenha sido programado. A diversão pode se caracterizar por uma sensação de realização e suas causas estão diretamente relacionadas com as da plenitude do estado de fluxo.

Quanto às atividades de lazer, podem ser caracterizadas de duas maneiras: a ativa (hobbies, esporte, socialização) e a passiva (consumo de mídia, principalmente TV), sendo que o lazer passivo produz pouco fluxo, ao contrário do lazer ativo. O paradoxo, descoberto nas pesquisas, é que as pessoas gastam mais tempo com o lazer passivo do que com o ativo.

\section{Criando experiências com o estado de fluxo}

O fluxo ocorre na decorrência de oito distintos fatores que se interrelacionam uns com os outros. Para que alcancemos o canal de fluxo, não é necessário que todos os fatores ocorram, e muito menos, em uma determinada ordem. Verificamos contudo que quanto mais fatores forem engajados, maiores as chances de nos envolvermos a esse canal de fluxo, e com toda a sua plenitude. São eles:

1. Tarefas com chances de se concluir, porém desafiadoras;

2. Capacidade em se concentrar na tarefa;

3. Ter regras claras; 
4. Atividades com metas bem definidas;

5. Feedback imediato;

6. Envolvente, a ponto de que excluam da consciência as preocupações do dia-a-dia;

7. Sensação de controle sobre as ações ou falta de preocupação em perder o controle;

8. Sensação de tempo alterada, o “tempo voa!”.

O primeiro e o mais complexo, o que muitos games designers indicam como ponto fundamental ao tratar de games, é o balanceamento entre o desafio e a habilidade do jogador, a fim de manter o jogador interessado, conectado e engajado com o game.

O segundo fator que deve ocorrer é a concentração e o foco, e é aqui que alguns games mais recentes pecam quando dão tarefas e informações demasiadas para o jogador, ou quando o próprio game distrai o jogador com excesso de efeitos gráficos e sonoros.

A terceira parte da teoria do fluxo sugere que para qualquer atividade é preciso ter regras claras. As regras precisar ser bem explicadas para que o indivíduo se foque no seu objetivo. Quanto menos regras, mais rápido será o envolvimento das pessoas.

O quarto deles é a existência de objetivos claros. Isso faz com que a pessoa fique com atenção neles, e ela fará o possível para atingi-los, isso aumenta sua concentração (outro fator para se manter no canal de fluxo).

O quinto fator, algo que os designers instrucionais desenvolvem, se trata da existência clara de retorno (feedback) para o jogador sobre suas ações e resultados, como premiações ou retorno imediato de resposta sobre as questões que estejam sendo desenvolvidas ao longo da atividade. Assim, como a sonoplastia e pequenas animações gráficas podem e devem auxiliar o jogador no entendimento sobre a ação e reação ao jogar o game. O retorno rápido pode ser uma das principais ferramentas para que direcionemos o jogador no canal de fluxo.

O sexto item, extremamente surpreendente, é quando a pessoa perde a noção de si mesma, e ela se torna amalgamada ao jogo, às vezes como se fizesse parte dele, esse evento é chamado de perda da sensação de autoconsciência, a ponto de, quando o jogador perde a partida e diz: "morri”. 
É como um efeito, uma fusão entre ação e atenção, quando a pessoa tornase tão atenta e envolvida ao que está fazendo a ponto de se desligar de todas as outras coisas, fazendo com que suas preocupações desapareçam.

Quanto ao sétimo, à sensação de controle da situação, também muito relevante em games, permite que o jogador tenha uma experiência muito melhor, ao não se sentir "trapaceado" pelas regras. Ou paradoxalmente, a atividade gerar uma falta de preocupação a ponto do indivíduo não se incomodar em perder o controle.

O oitavo fator é a sensação de tempo distorcida, quando a pessoa está tão interessada no que está fazendo que ela releva suas necessidades fisiológicas como comer e dormir. A medida de duração com referência a eventos externos como noite e dia, ou a evolução ordenada das horas, torna-se irrelevante pelos ritmos ditados pela atividade.

Frequentemente as horas parecem passar como se fossem minutos; em geral a maioria das pessoas relata que o tempo parece passar mais rápido, conclui Csikszentmihalyi (1999).

\section{Fluxo e motivação}

Teorias de motivação geralmente negligenciam os fenômenos em torno da pessoa a qual a motivação é atribuída. Eles explicam sobre as razões das ações e resultados ao invés do processo (SANSONE \& HARACKIEWICZ, 1996). Como a pessoa estava se sentindo enquanto estava em atividade tende a ser ignorado.

Csikszentmihalyi (1998) em suas pesquisas sugere que a experiência fenomenológica do fluxo é uma poderosa força motivacional. Quando os indivíduos estão totalmente envolvidos em uma determinada atividade, eles tendem a achar a atividade divertida e intrinsecamente recompensadora.

Independentemente da motivação original para se jogar xadrez ou sair com amigos, as atividades não se estenderão a não ser que se mantenham divertidas ou ao menos as pessoas estiverem motivadas por extrínsecas recompensas. 


\section{Porque oferecer games educativos aos alunos?}

Os estudantes dispõem de um determinado número de horas no seu dia-adia no qual se envolvem com ferramentas interativas ou não. Entretanto, essas ferramentas podem ser acessadas dentro e fora da sala de aula (atualmente, mais fora da sala de aula), com a finalidade de envolver ativamente os alunos no processo de ensino-aprendizagem.

Nesse contexto, os games educativos se apresentam como excelentes objetos de aprendizagem por proporcionarem um estado de fluxo ao jogadorestudante. De acordo com Mattar (2010), no caso do jogador, ao mesmo tempo em que ele fica em estado de fluxo (no sentido de que está desligado do mundo e com atenção total ao game), também exercita o seu senso crítico (porque está assumindo múltiplas perspectivas dentro do game).

Devemos convidar os nossos estudantes a se utilizarem de games educativos e de outras atividades instrucionais como atividades complementares, a fim de desenvolverem suas habilidades e competências educacionais. Entretanto se essas atividades educacionais não os mantiverem no canal de fluxo, os perderemos para nossos “concorrentes" diretos, como a TV e games de entretenimento.

A geração de estudantes que já nasceram e cresceram na era das TICs, podendo variar de acordo com a sua situação social, demandam um processo de aprendizagem não-linear e muito mais dinâmico que o tradicional, indicando que novas metodologias e tecnologias educacionais mais convincentes e atraentes sejam criadas por nós.

\section{Produzindo games educativos com fluxo}

Os games educativos não são criados e desenvolvidos exclusivamente para divertir, mas para proporcionar aprendizado e desenvolvimento de determinadas habilidades, assim temos como estratégia: ensinar através do entretenimento.

Ralph Koster (2004), game designer americano, se utiliza de algumas metáforas para representar a necessidade de os games se posicionarem em um espaço mágico que não cause tédio nem excesso de trabalho cognitivo para o jogador; pois, as duas situações gerariam desinteresse pelo game: um navegar 
entre a privação e a sobrecarga, entre o caos excessivo e a ordem excessiva, o silêncio e o barulho.

Para isso, precisamos nos apropriar de todas essas relações em torno do estado de fluxo e desenvolver projetos de games educativos que conduzam seus jogadores a se manterem no canal de fluxo (Diagrama 12), e como game designers podemos estabelecer essa dinâmica através da criação dos objetivos, regras, balanceamento, retorno de resultados, animações e premiação nesses games.

Vale ressaltar que, quando se trata de um game, o fluxo não é o estado da vitória, mas o estado em que ele ainda não sabe se vencerá, se superará seus desafios e quais novos obstáculos aparecerão. (MATTAR, 2010, p.34)

Uma solução que oferece autonomia ao jogador é disponibilizar vários níveis de dificuldade, dando autonomia ao jogador em relação ao número de tentativas que serão executadas. Todos partem do mesmo ponto, porém, a cada nível é exigido que suas habilidades sejam mais precisas e apuradas, isso significa, literalmente, chegar ao final de um nível e começar o próximo, independente do número de tentativas fazendo com que o jogador fique cada vez mais engajando aos desafios do game, gerando um constante estímulo e, assim, propiciando que o jogador se desenvolva através do conteúdo do game educativo, beneficiando o seu aprendizado.

Esse fator seria a capacidade de manter o jogador sempre retido em uma zona limite, em que o game não é muito difícil (“eu desisto!”) nem muito fácil (“eu não me sinto desafiado!”) (PRENSKY, 2010).

Esse processo permite que alunos com distintos potenciais para o aprendizado façam um bom uso de um mesmo game, e esse ambiente digital e virtual oferece ao aluno iniciante tantas possibilidades quanto ofertadas ao aluno mediano, note-se que nada impede que o aluno iniciante, imbuído de um estado de fluxo, dedique ainda mais tempo e conquiste mais níveis no game e, consequentemente, avance em seu aprendizado. 


\section{Dez passos para o desenvolvimento de games educativos}

Prensky (2008), sintetiza as demandas para a produção de games educativos, visando a obtenção do estado de fluxo, a partir de 8 itens essenciais, conforme podemos ver a seguir:

1. Definir o público-alvo;

2. Definir do conteúdo;

3. Cuidar para que tenha uma ótima aderência ao currículo;

4. Criar jogos com fases de curto período de tempo (MINIGAMES);

5. Desenvolver o game de forma que o jogador-aluno se mantenha no canal de fluxo;

6. Desenvolver o game com diversos níveis de dificuldade ;

7. Incluir novos elementos a cada nível do game;

8. Oferecer autonomia de tempo ao aluno, visando o seu progresso no aprendizado;

9. Sistematizar as informações dos games jogados pelos alunos para o professor;

10. Aplicar como atividade complementar (considerando a pedagogia escolar atual).

O atual sistema educacional pode não ser o mais adequado para educar as novas gerações. Precisamos dar voz a essas gerações, caso contrário, nossas escolas ficarão desertas, ou repletas de alunos com suas mentes em outros lugares. Precisamos incluí-los, engajá-los e envolvê-los em um novo cenário de ensinoaprendizagem, fazendo com que se sintam no canal de fluxo ao participar das atividades escolares dentro ou fora da sala-de-aula. promovendo uma melhor qualidade de vida em seu aprendizado, como consequência.

De acordo com o que apresentamos, o game educativo é um dos objetos digitais de aprendizagem que podem promover uma conexão nas relações aluno-aluno, aluno-professor e aluno-aprendizado. E alguns dos autores, citados até o momento, acreditam que os games educativos impactarão positivamente a educação. 


\section{4.}

\section{Games Educativos: seu uso no ambiente de aprendizado}

"A educação pode ser apoiada pelo uso de jogos e outras mídias interativas, especialmente para temas que freqüentemente são difíceis de entender e visualizar", disse Rik Eberhardt (2014), gerente do laboratório de game design do MIT.

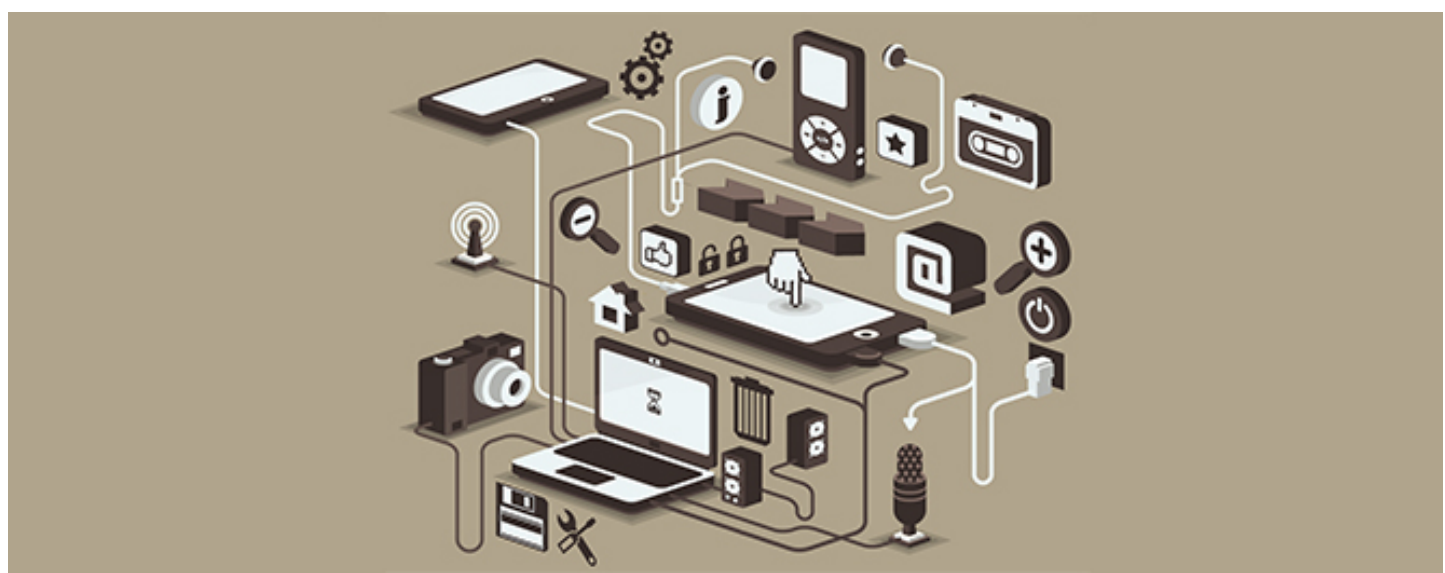

Diagrama 19. Diversidade de ferramentas digitais para pesquisa e produção de conteúdo Fonte: www.simplify360.com

Assim como Eberhardt, cada vez mais professores e especialistas na área percebem que educar vai muito além dos clássicos giz e lousa da sala de aula. Utilizar games, que aliam aspectos lúdicos a conteúdos pedagógicos, pode auxiliar tanto no processo de aprendizagem das disciplinas tradicionais quanto no desenvolvimento integral dos alunos. Não é a toa, escolas de todo o mundo têm incluído os games educativos, jogos sérios de entretenimento (cap.4.2) e simuladores em sua metodologia pedagógica nos mais variados níveis de ensino. São mecânicas clássicas dos tradicionais games de entretenimento que os alunos encontram em seus consoles, computadores domésticos ou nas lan houses, e que são tematizados e adaptados para os conteúdos dos currículos escolares. A demanda para a produção de games educativos tem sido crescente à medida que mais instituições se interessam em usar o meio como uma ferramenta de ensino. 
O surgimento de aprendizagem baseada em games, segundo o game designer americano Marc Prensky (2010), surgiu nas últimas décadas do século 20, quando houve um boom da tecnologia global. As gerações de estudantes que estão nos últimos anos da escola, parte da população mundial com acesso a tecnologia, viveram suas vidas inteiras com acesso a tecnologia - não apenas computadores, mas também com a música, vídeos digitalizados, telefones celulares, videogames e uma série de outros aparelhos mais sofisticados. Devido a esse acesso à tecnologia, o game designer afirma que

Os estudantes de hoje pensam e se informam em processos fundamentalmente diferentes do que seus antecessores. (Prensky, 2012, p.23)

Ou seja, os professores, ou o que Prensky chama de "imigrantes digitais" e que agora precisam se adaptar à linguagem e estilos de aprendizagem dos "nativos digitais", um termo que ele usa para descrever os estudantes que sempre foram cercados por tecnologia.

Prensky (2012) recomenda aos professores que implementem games educativos como ferramentas de aprendizagem na sala de aula ou para depois da aula. Os games podem beneficiar diversas áreas e em uma grande variedade de aplicações. A “arte” de criar uma aprendizagem baseada em games está integrando tudo o que se conhece de ludosofia, pedagogia e mídia digital dando forma a um jogo divertido e que cumpra a missão de ensinar.

De acordo com a consultora americana em educação Patricia Deubel (2006), a aprendizagem digital baseada em games tem o potencial de envolver e motivar os alunos além de oferecer experiências de aprendizagem personalizadas (plataformas adaptativas), promovendo a memória de longo prazo e fornecendo simulações de experiências práticas. A consultora sugere que os professores efetivamente usem o game em sala de aula, eles devem primeiro encontrar games não violentos que facilitem o planejamento e a solução de problemas e acima de tudo ter aderência com o currículo escolar. Por sua vez, Deubel recomenda RPGs (role-playing games), simulações e jogos de aventura, porque muitas vezes é válido apelar para o desenvolvimento de mais de uma habilidade, como por exemplo: vocabulário, leitura, visão periférica e rapidez mental.

Um bom exemplo de RPG é a plataforma brasileira OJE (www.acre.oje.inf.br), que funciona a partir de uma narrativa de aventura, com a 
estrutura de uma rede social, onde os personagens acessam uma variedade de jogos digitais e objetos de aprendizagem, articulando habilidades cognitivas e colaborativas. Os desafios da aventura incluem jogos casuais, jogos de leitura e enigmas inspirados na matriz de competências do ENEM (Exame Nacional do Ensino Médio), organizados como uma experiência lúdica transformadora do desejo de aprender.

Já Luciano Meira, criador da plataforma OJE, comenta em um vídeo no portal do projeto que a narrativa e a aventura podem gerar na motivação e na criação, não necessariamente novas técnicas de “ensinagem”, mas de cenários inovadores de aprendizagem, próprios à audiência e às demandas de nosso tempo.

O desafio de educadores, pedagogos, designers instrucionais e game designers é desenvolver games educativos com um acompanhamento pedagógico para que os estudantes aprendam brincando ou brinquem aprendendo.

\section{Benefícios da aprendizagem baseada em jogos digitais}

A aprendizagem baseada em jogos digitais (DGBL, na sigla em inglês “Digital Game Based Learning”), explica Prensky (2010), é um método de ensino que incorpora conteúdo educativo ou princípios de aprendizagem através de games, com o objetivo de envolver os alunos. As aplicações de aprendizagem baseada em jogos digitais recorrem à teoria construtivista de ensino. Os jogos sérios, jogos casuais e simuladores podem oferecer propósitos que vão além do entretenimento - eles podem ser usados para o ensino.

Sendo assim, Prensky, tomando por base a teoria construtivista de ensino, afirma que a aprendizagem digital baseada em games (DGBL) conecta conteúdo educativo com jogos de computador ou vídeo e pode ser usada em quase todas as disciplinas e níveis de habilidade. Os defensores desse modelo de aprendizagem afirmam que é possível oferecer oportunidades de aprendizado que envolvam os alunos no ensino interativo e que os ajudem a se preparar para participar da sociedade tecnológica e globalizada do século 21.

A aprendizagem tradicional é muitas vezes passiva, mas os games mantêm o aluno focado porque o leva a agir e, então, a reagir com base na questão que ele recebe. Aprender fazendo é mais divertido, mais envolvente, e muito mais eficaz. 
Plataformas como o Brainrush de Nolan Bushnell, têm ferramentas que em cada nível de um respectivo game, a plataforma adaptativa pode entender um pouco sobre o que o estudante-jogador sabe e, em seguida, faz adaptações no game para corresponder à capacidade de aprendizado daquele aluno. Isso mantém o aluno em um ponto confortável - que não é muito fácil e nem muito difícil - onde a aprendizagem é otimizada.

Esse aluno quando está envolvido nesse ponto confortável de aprendizagem vai encontrar-se em um estado de fluxo. Os games que motivam oferecem efeitos colaterais que podem incluir perda de noção do tempo e um profundo sentimento de realização ao concluir um nível de desafio.

\section{Em que condições os games educativos estão sendo utilizados pelos alunos no Brasil e no mundo?}

Considerando a qualidade tecnológica aplicada à educação, o americano James Paul Gee (2005), que é referência mundial no uso de games em educação, chama a atenção para a disparidade que a cultura do videogame pode gerar, em função de restrições de acesso para a população mais pobre e menos instrumentalizada.

Apesar do atraso no acesso à informática do Brasil em relação a outros países, mais da metade das escolas públicas já se aparelharam com laboratórios de informática, que se tornou política pública no país. Muitas vezes, é necessário aguardar não só o aparelhamento da escola, da cidade, mas de todo o município. Por enquanto, ainda temos alunos que buscam as tradicionais lan houses, quando não têm computadores e afins em casa. No Brasil, mais de 50\% das residências já contam com pelo menos um computador ligado à internet com banda larga. Segundo levantamento da Associação Brasileira de Telecomunicações (Telebrasil), até o final de 2014, a infraestrutura de banda larga fixa estará presente em todos os municípios brasileiros, estimulados pela implementação do Plano Nacional de Banda Larga (PNBL) do Ministério das Comunicações.

No entanto, os laboratórios de informática na rede pública ainda têm prestado um serviço limitado, pois estão mais voltados para o ensino de softwares como Word (para redações), Power Point (para apresentações) e o uso da internet (para pesquisa), ao invés dos alunos fazerem uso dos softwares em prol de aprendizado mais amplo e envolvente, a fim de aprimorar e reforçar o 
conteúdo curricular vigente, como propõem os objetos de aprendizado digitais, dentre eles os games educativos. A adaptação das escolas para oferecer uma infra-estrutura mais moderna com conexão à internet para os estudantes está avançando, porém em uma velocidade mais lenta do que seus alunos desejam.

\section{Novas metodologias com conteúdo digital}

O passo seguinte ao aparelhamento escolar e a utilização das TICs é criar novas metodologias educacionais que façam uso de objetos de aprendizado digitais, como consultas a informação e textos através da internet, vídeoaulas, vídeos, games educativos, exercícios digitais, classificadores de conteúdo, editores de vídeo e áudio, infográficos etc. Os alunos, ao usarem o computador de maneira dinâmica e divertida, aprendem através do uso da tecnologia e se apropriam das ferramentas com as quais as mídias digitais podem auxiliá-los nas demandas de seu desenvolvimento escolar e posteriormente em sua vida profissional.

É inegável que estamos em um processo de transição e adaptação do uso de tecnologia no ambiente escolar e é fundamental que as metodologias educacionais acompanhem esse processo e, cada vez mais, façam uso de objetos de aprendizagem digital que ofereçam aderência ao currículo escolar. A própria tecnologia oferece a possibilidade de que os objetos digitais possam ser utilizados tanto dentro ou fora da sala de aula. O primeiro objeto de aprendizagem digital de que se tem conhecimento foi o Programa Logos de Papert (1989), matemático americano, aplicado a alunos em 1971, no qual foi oferecido aos mesmos a possibilidade de programarem uma imagem ou padrão na então tela preta com letras verdes. O envolvimento dos alunos com a nova dinâmica oferecida pelo objeto de aprendizado foi um sucesso. De lá pra cá, muitos países como ao EUA, Inglaterra e Austrália, têm aplicado ferramentas de aprendizado digital desde os anos 1990 e que já fazem parte de suas metodologias educacionais.

Além do uso do computador na escola ou em casa, a tecnologia nos proporciona a possibilidade de explorar o universo e versatilidade dos dispositivos móveis. Emil Ovemar, um dos fundadores da desenvolvedora sueca de aplicativos Toca Boca para tablets e celulares, em entrevista para o caderno de tecnologia do 
The Guardian (2015) contabiliza mais de 85 milhões de downloads e conta que eles levaram os games para as escolas, a fim de experimentá-los, contudo, os adultos podem não entender por que esses games são divertidos, mas as crianças sabem o que querem. Nos EUA, em 2011, 38\% das crianças de ate 8 anos já tinham usado um aparelho móvel, já em 2013, passaram a 72\%. Games casuais como os do Toca Boca, que estimulam habilidades do dia-a-dia, e games educativos para crianças que ainda não são letradas se igualam em importância para o aprendizado e apoio ao seu currículo escolar.

Os game designers têm tido o desafio de elaborar games educativos que façam com que o estudante deixe de se relacionar com o objeto de aprendizado com formalidade e se sinta mais como um jogador do que um aprendiz. Também demandam que os jogadores/estudantes tenham um melhor entendimento do conteúdo, através do aprendizado periférico, conforme vão dedicando mais tempo ao game.

\section{Jogar na escola e jogar em casa}

As crianças têm vivenciado, quando não estão na escola, um intenso contato com os games e tantos outros recursos possíveis nos dispositivos móveis, o que faz Prensky (2010) sintetizar essa realidade afirmando que as crianças se desligam quando vão à escola e se ligam quando saem dela. O game designer insiste que é imensa a disparidade do nível de contato dos estudantes com as tecnologias digitais ao estarem dentro e fora da sala de aula. A metodologia educacional precisa ser renovada com urgência para restabelecermos o interesse dos alunos em seu aprendizado na escola e fazer uso de uma tecnologia que está à disposição da sociedade, desde o simples envio de uma mensagem via celular, o uso da internet ou até as imersões em plataformas de games educacionais.

Contudo, Prensky (2006, em seu livro "Não me atrapalhe, mãe - Eu estou aprendendo!”, p. 288) é categórico em afirmar que nossos filhos já estão no caminho de um novo “currículo” doméstico.

O “currículo" disponível em casa, através das redes, não costuma ser visto dessa forma, mas, na verdade, supera, em amplitude, o adotado em nossas escolas. Ele possui o potencial de encaminhar nossos filhos, muito além da 
capacidade e conhecimento de seus professores, pelo séc.XXI - o século deles. (PRENSKY, 2010, p.289)

Segundo o executivo americano John Kernan, da Lightspan, que desde 1993 desenvolve games educativos, ao jogarem em casa uma média de 50 minutos por dia (diagrama 13), os estudantes de fato obtêm um dia extra de escola na semana, o que significa, quase dois meses a mais por ano.

Quais as mídias que as crianças brasileiras, de 1 a 10 anos, assistem em casa diariamente?

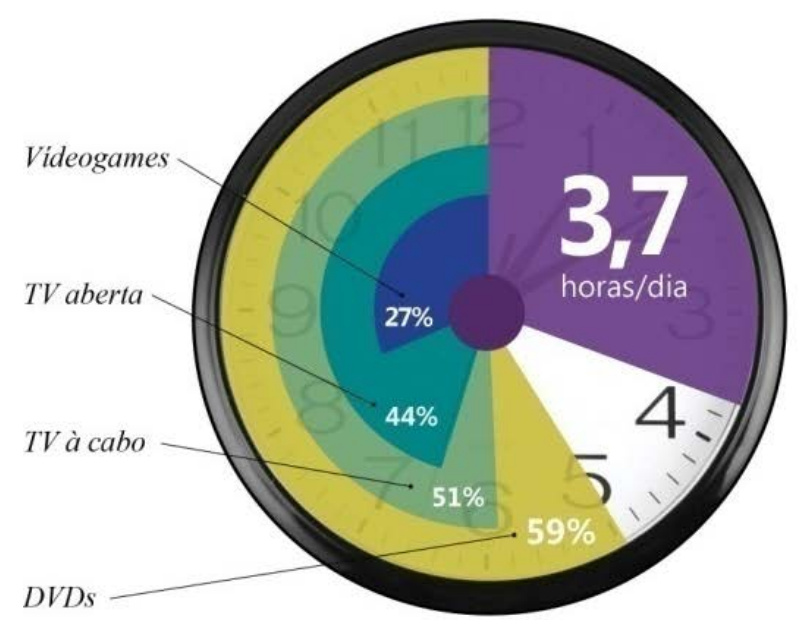

Fonte: Sophie Mind Pesquisa e Inteligência de Mercado 2011
Das 3,7 horas/dia, se a criança jogar 50 $\mathrm{min} /$ dia de game educativo ao longo de 6 dias na semana $=1$ dia de aula

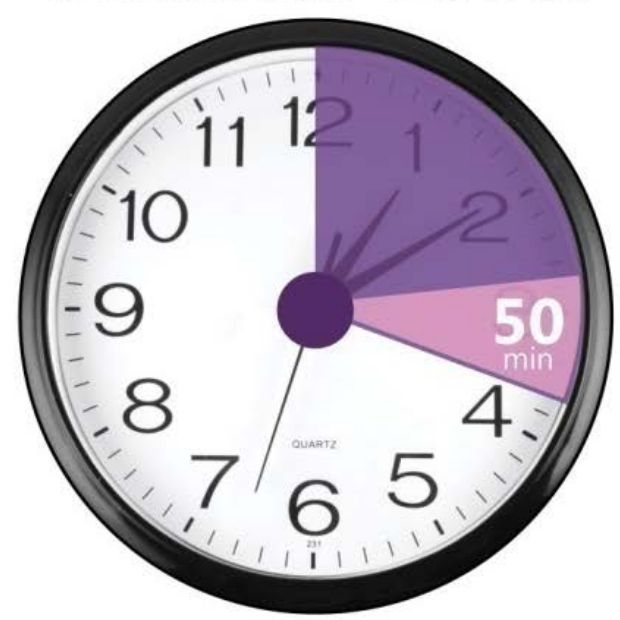

Fonte: Marc Prensky (2010)

Diagrama 20. Levantamento do tempo diário do consumo de mídia digital Fonte: $\mathrm{O}$ autor

Essa sugestão, em relação ao uso diário de games educativos, também é reforçada, nada mais nada menos, por Nolan Bushnell (2013), criador do Atari e da plataforma de games educativos Brainrush, além de Marc Prensky (2008), em suas palestras, incentivam os estudantes a fazerem uso de games educativos em casa por pelo menos 50 minutos diários. Somando-se esse tempo, ao longo de uma semana, o estudante terá se proporcionado um dia a mais de aprendizado.

Assim, seria muito positivo que jovens aprendizes desprendam de uma fração do tempo que jogam games de entretenimento para jogar games educativos (Figura 27). Que, por sua vez, precisam se apropriar de algumas dinâmicas dos games de entretenimento que tanto envolvem e motivam esse público jovem. 


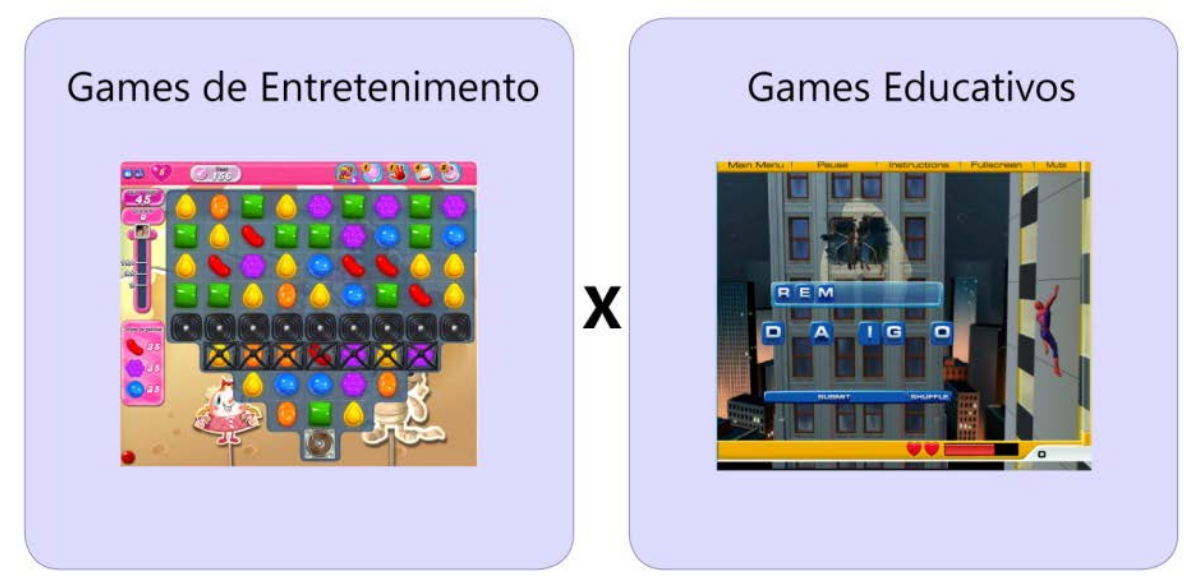

Diagrama 21. Game de Entretenimento (Ex.: Candy Crush) x Game Educativo (Ex.:Spiderman 2 - Web of Words)

Fonte: $\mathrm{O}$ autor

Enquanto não for possível a escola incluir as tecnologias digitais educacionais, a melhor maneira de fazer a diferença e potencializar os estudos, não se encontra nas instituições, mas em casa. Alguns exemplos de games educativos e de entretenimento que tem a função de aprendizado específico podem ser encontrados, mais adiante, no capítulo 4.2 (Recomendação de Games Educativos).

A educação precisa acompanhar as mudanças impostas pela tecnologia da informação com suas mídias e produtos, deslumbrantes e atraentes, que seduzem crianças e jovens com seus frequentes lançamentos e inovações. Contudo, os pedagogos e educadores precisam alinhar aquilo que melhor sabem fazer com esta nova realidade que é mais familiar para o aluno do que para o próprio professor. É necessário inserir estas novas tecnologias em suas complexas metodologias pedagógicas.

\section{Games para indivíduos com necessidades especiais}

Podemos atribuir bons méritos ao uso de games com crianças que possuem necessidades especiais, segundo o psicólogo inglês Mark Griffiths (2011). Ele registrou alguns casos em que os games causaram um efeito calmante sobre crianças com autismo. O psicólogo também fornece dados de pesquisa que sugere que os adolescentes com transtorno de déficit de atenção podem ter melhorias em "graus, sociabilidade e capacidade de organização", quando jogam games educacionais. Além disso, Griffiths apregoa os possíveis benefícios do uso de 
games educativos com crianças que apresentam um quadro de diabetes e outras formas de doenças que necessitam de reabilitação.

Apropriados da realidade virtual, de acordo com Springer (2010), psiquiatra americano, os games podem tanto permitir que usuários de videogames escapem do mundo real, como podem ajudar os portadores de necessidades especiais a “experimentarem” o mundo real, navegando por lugares que realmente existem!

Durante a última década, pequenas empresas, pesquisadores e desenvolvedores de games independentes desenvolveram inúmeros games que buscam acomodar as habilidades de jogadores com deficiências mais graves, seja mental, visual, física ou auditiva. Com isso, definiram-se as seguintes categorias para o game acessível (SPRINGER, 2010):

Games de áudio são jogos especificamente para gamers que são cegos. Estes jogos podem ser jogados sem feedback visual e passar a usar técnicas de áudio baseado , como pistas de áudio ou voz sintética. O site audiogames fornece uma visão abrangente dos games disponíveis, além do game “Onae, a aventura de Zoe”, desenvolvido pela Organização Nacional de Cegos Espanhóis (Cidat - Once). Nesse game, os jogadores se deslocam através de um labirinto, somente com o auxílio de áudio.

Games One-switch são jogos que podem ser jogados utilizando um comando e que acomoda as habilidades dos usuários com limitações motoras graves ou com deficiências cognitivas.

Games para pessoas com dificuldades de aprendizagem, aqueles específicos para as pessoas com dificuldades de aprendizagem, baixo nível de alfabetização ou uma combinação de necessidades complexas, por exemplo, como um indivíduo de coordenação limitada.

Os games acessíveis oferecem múltiplas interfaces para suportar diferentes tipos de deficiências. As limitações singulares do grupo-alvo tornam esses projetos interessantes, instrutivos e desafiadores para especialistas e pesquisadores.

Dessa forma, fica demonstrado que existem muitas as variáveis e um universo de possibilidades que fazem dos games uma excelente ferramenta de contribuição para o aprendizado de seus usuários, sejam eles indivíduos com demandas especiais ou não. 


\section{1}

\section{Agregando valor aos games educativos}

No universo educacional, já são conhecidas e praticadas atividades lúdicas em meio às tradicionais. Entretanto, quais seriam as vantagens apresentadas pelas mídias digitais ou mais precisamente pelo game educativo, que é especificamente o nosso objeto de pesquisa?

São muitas as vantagens, e com as quais foi organizado o diagrama 14, composto a partir de três campos de conhecimento (tecnologia, educação e ciência) e constituindo o que chamamos de cérebro do game educativo.

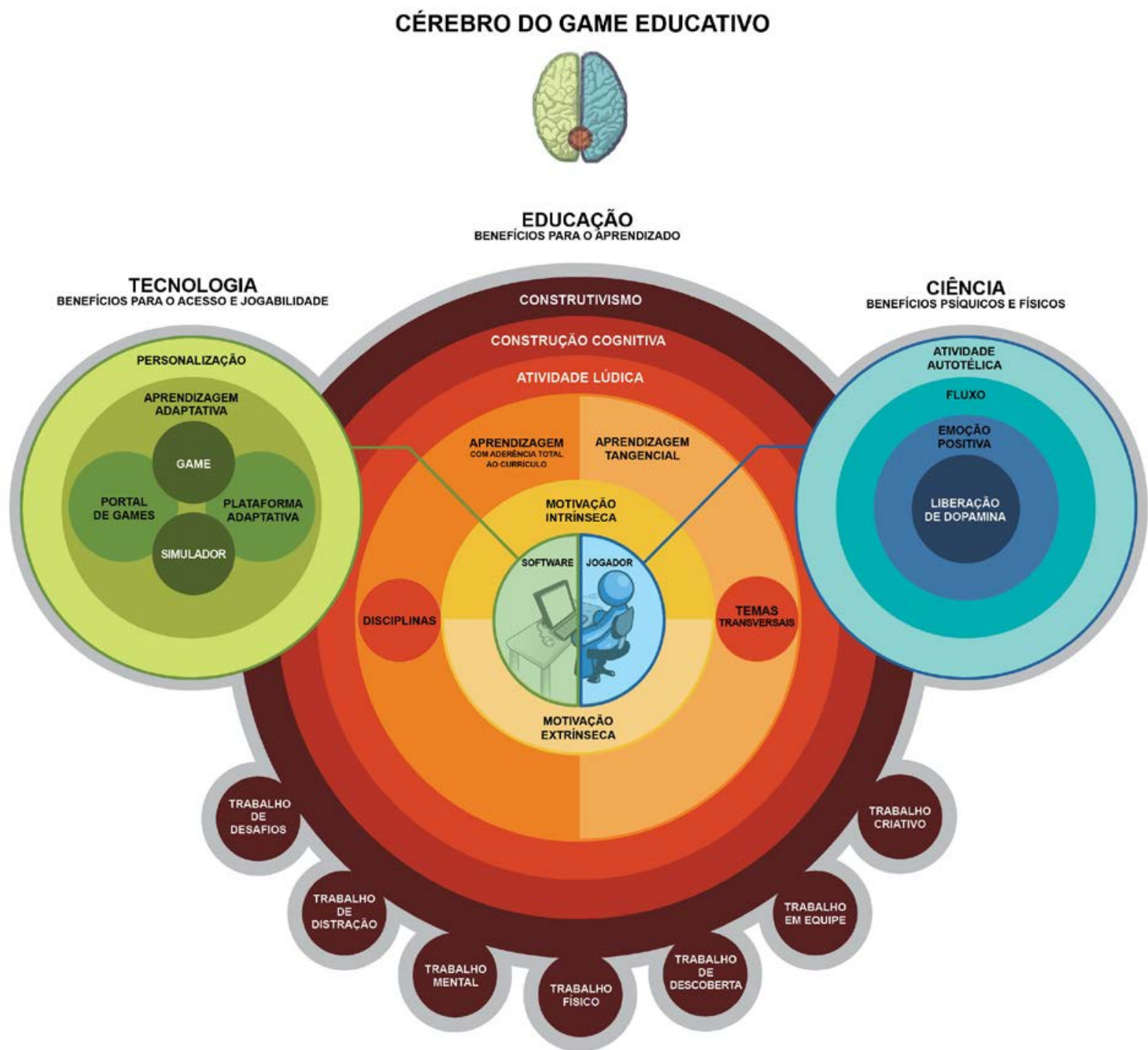

Diagrama 22. Cérebro do game educativo Fonte: $\mathrm{O}$ autor 
Partindo de uma linha pedagógica, a que se insere a aplicação dos games educativos, precisamos considerar o uso da proposta construtivista de Piaget, que levou Papert (1986) à pedagogia do pensamento construcionista, conceituando o indivíduo, além de ser responsável pela construção de seu conhecimento, e poder utilizar ferramentas para facilitar esse processo. Assim, o produto dessa construção pode ser apresentado, debatido, examinado e admirado. O matemático e educador americano comenta que a metodologia educacional que prioriza os textos escritos e impressos como ferramentas indispensáveis ao ensino, deve ser repensada e incluir as tecnologias da informação que, por sua vez, nos oferecem novos e dinâmicos meios interativos, nos conduzindo a novas tecnologias educacionais para atrair, envolver, auxiliar e informar nossos estudantes em uma aprendizagem que contribui para sua futura formação profissional. O construcionismo defende que uma maior aprendizagem pode ser proporcionada aos alunos com o mínimo de interferência de um instrutor ou professor.

Como parte desse contexto, os games se revelam como objetos transacionais, de acordo com Schwartz (2014), ou seja, é fundamental entender que a proposta de sua narrativa é através de uma construção cognitiva e não apenas como um texto de formato determinado.

Games educativos oferecem versatilidade ao educar divertindo, e também podem aprimorar as habilidades cognitivas e psicomotoras. Embora a aprendizagem através de jogos possa ser muito eficaz, os games educativos podem se tornar uma distração, levando os alunos a se tornarem demasiadamente focados na atividade lúdica e não no aprendizado. Por outro lado, pode se tratar de uma vantagem fazendo com que o game produza o efeito favorável de uma aprendizagem tangencial e envolver diversas habilidades de aprendizado sem que o aluno perceba que está, na prática, estudando. Para Mattar (2010) é um conceito, em que não prevalece o que você aprende ao ser ensinado diretamente, mas o que aprende ao ser exposto a coisas.

Para isso, precisamos de objetos de aprendizado como os games educativos, porque além de muito eficientes em abordar de forma lúdica as questões das áreas de conhecimento e suas disciplinas do tradicional currículo escolar, eles também são eficazes ao apresentar temas transversais aos alunos. Esses temas expressam conceitos, valores básicos à democracia e à cidadania e, também, obedecem a questões importantes e urgentes para a sociedade contemporânea. A ética, o meio 
ambiente, a saúde, o trabalho e o consumo, a orientação sexual e a pluralidade cultural não são disciplinas autônomas, mas temas que permeiam todas as áreas do conhecimento, e estão sendo intensamente vividos pela sociedade, pelas comunidades, pelas famílias, pelos alunos e educadores em seu cotidiano. Recentemente, surgiram demandas sobre Orientação para o Trânsito, Mobilidade Urbana e Educação Financeira, cujos temas estão se tornando políticas públicas. Entretanto, seja para as disciplinas tradicionais como para os temas transversais, precisamos desenvolver um aprendizado que envolva o aluno de hoje, que requisita tanto se identificar com sua cultura local, assim como, ter acesso à informação de todos os cantos do mundo.

Os alunos de hoje, fazem parte das gerações $\mathrm{Y}, \mathrm{Z}$ e Alfa, que tem se habituado com a oferta do mercado consumidor, a personalizar desde seus objetos pessoais a suas ferramentas digitais, como incluir seu nome, sua foto ou criar avatares, escolher seus perfis prediletos para a apresentação etc. Como usuário, é possível personalizar muitas coisas na internet e sobretudo nos games. Para educação podemos oferecer aos alunos o controle para que eles personalizem a sua educação e determinem por si só, de que forma vão aprender. Os próprios alunos (usuários) ficam livres para descobrir, criar e ordenar os aprendizados, conforme, eles próprios determinarem, assumindo papéis ativos nos games.

Essa autonomia do aluno-usuário nos conduz à aprendizagem ativa, que possibilita ao aluno jogar de acordo com o seu entendimento pessoal, tempo e proficiência. O aluno se sente empoderado por essa autonomia, que o conduz a uma sensação de auto-aprendizado, mais excitante e envolvente que as aulas tradicionais. Dessa forma, o game se transforma em um recurso didático a favor da educação, segundo Valente (2010), focado no processo de construção, cujo caminho pode ser determinado pelo próprio aluno, em conjunto com seus pares e sob a orientação de seus professores, o que propiciará a educação na direção de um novo design instrucional, um ensino simultaneamente sério e divertido, respeitando-se as capacidades e os potenciais dos alunos.

De acordo com Mattar (2010), a interatividade entre o aluno e os games, é mútua, sendo o jogador constantemente convidado, por esse objeto digital de aprendizagem, a participar de forma ativa e estratégica, motivando-o a progredir em suas conquistas e a seguir para novas fases do game com novos desafios a vencer. 
Para além dos games, esse ambiente digital e hipermídia ainda propicia ao aluno a possibilidade de simular atividades experimentais, educacionais (de esportivas a vôos espaciais) e reações físico-químicas (de água a elementos explosivos), dispensando um ambiente físico experimental ou a confecção de protótipos. Nesse ambiente, os simuladores estimulam a prática e possibilitam a transferência do aprendizado e de habilidades do mundo real, com a vantagem de que os erros fazem parte desse aprendizado e não oferecem perigo ao aprendiz, como, por exemplo, fazer transfusões de sangue ou misturar elementos químicos.

Tanto os simuladores e games educativos como os games de entretenimento podem ser encontrados na internet, gratuitamente, com seus links específicos ou agrupados em portais de games. Também podemos encontrar games educativos produzidos por empresas privadas, organizados em plataformas adaptativas, tornando-se potenciais ferramentas de aprendizado, em que todo o processo do aluno-jogador é registrado pelo sistema da plataforma conforme ele vai jogando. Esse acompanhamento, para Papert (1986), permite que se aprenda mais e de maneira mais efetiva, tendo o controle consciente do processo de aprendizagem, tanto para os estudantes como para o beneficio de seus professores que através das estatísticas organizadas pela plataforma, podem fazer avaliações tanto individualmente como de toda a classe. Além disso, pode-se organizar plataformas com games coletivos, convidando a interação entre várias pessoas, incentivando o trabalho em equipe, e também proporcionando um ambiente livre que permita o reforço de diversas competências.

Independente do interesse de um aluno-jogador em buscar um game educativo individual ou coletivo, para os game designers, prevalece o foco em desenvolver um jogo que seja atraente, envolvente e ensine ao mesmo tempo. Há o termo científico, cunhado pelo psicólogo húngaro Csikszenmihályi (1988), e atribuído ao envolvimento e interesse em uma atividade denominada autotélica. Procuramos realizar atividades autotélicas, segundo a game designer americana Jane McGonigal (2012), porque elas nos envolvem completamente, e porque o envolvimento intenso é o estado emocional mais prazeroso, gratificante e significativo que podemos vivenciar.

Para o psicólogo Csikszenmihályi, através de atividades autotélicas podemos atingir o "fluxo" (detalhado no capítulo 3.4), estado em que nos colocamos totalmente imersos e absorvidos por um desafio. O fluxo se dá quando 
mantemos uma sinergia entre o nível de dificuldade da realização de uma atividade, e o desenvolvimento de habilidades necessárias para atingir a sua realização. Assim como "fluxo", de acordo com McGonigal (2012), alguns criadores de games têm adotado a palavra italiana "fiero", tradução literal para orgulho, para descrever o que sentimos ao triunfarmos sobre a adversidade, similar a uma expressão física universal quando erguemos os braços sobre as cabeças e gritamos ao celebrarmos algo que foi superado.

Se nos sentirmos capazes de corresponder ao desafio, estaremos altamente motivados, extremamente interessados e positivamente envolvidos em situações estressantes. E esses são os estados emocionais decisivos que equivalem ao bemestar geral, e que os tornam a razão pela qual os atuais games de maior sucesso são tão viciantes e suscetíveis a mudar o nosso humor. (McGonigal, 2012, p.41)

Portanto, um bom game é uma oportunidade para proporcionar essa experiência e provocar uma emoção positiva pelas suas conquistas. E com todo esse envolvimento, segundo Schwartz (2014), gerado pelas dinâmicas dos games com seus feedbacks, balanceamentos e recompensas, ainda estimulados por meios audiovisuais e sonoros, geram a liberação de dopamina (o principal neurotransmissor humano que causa a sensação de alegria e prazer). Segundo McGonigal (2012), ao conquistar algo que é muito difícil para os jogadores, como um quebra-cabeça ou terminar uma corrida entre os primeiros lugares, nosso cérebros liberam um poderoso coquetel, que além da dopamina, produz norepinefrina e epinefrina. Essas três substâncias neuroquímicas combinadas produzem uma sensação de satisfação, orgulho e de alerta. Se o game provocar risos, o jogador produzirá ainda mais dopamina. Para a escritora Elizabeth Gilbert a definição de felicidade, comenta McGonigal (2012), é consequência do esforço pessoal e quanto mais trabalharmos para vivenciarmos as recompensas intrínsecas, mais fortes se tornarão nossas capacidades internas de fabricar felicidade.

É importante esclarecer, que as recompensas intrínsecas não têm como objetivo principal chegar em primeiro, fazer mais pontos ou vencer uma batalha entre exércitos. Por essas razões, sua aplicação é tão apreciada em metodologias educacionais, pois apresentam um propósito, no caso de games, como construir desde um objeto ou até uma cidade, pilotar um avião ou misturar elementos químicos reagentes, encontrar itens misteriosos ou encaixar imagens para desvendar algum desafio. Dessa forma, o mérito do game é a própria experiência da dinâmica, ou seja, a motivação intrínseca, que estimula a realização de determinadas 
atividades consideradas interessantes, atraentes ou capazes de fornecer algum tipo de satisfação ao indivíduo (BORUCHOVITCH; BZUNECK, 2004).

Contudo, há um contra ponto, uma estratégia para provocar tanta empolgação e envolvimento em alunos ao jogar, que é o uso de motivação extrínseca, que corresponde a estímulos externos ao indivíduo e que o motivam a realizar alguma atividade ou tarefa. A execução da tarefa, por si só, pode deixar de ser o motivo principal de seu interesse para, então, passar a ser o intuito de obter recompensas.

Ruiz (2004) classifica em quatro os tipos de recompensas extrínsecas que podem ser ofertadas no ambiente escolar:

1. Recompensas materiais: prêmios, objetos, dinheiro, itens comestíveis etc.

2. Atividades recompensadoras e privilégios especiais: oportunidades especiais ao jogador, uso de equipamentos, escolha de uma atividade etc.

3. Reconhecimentos: colocação em ranking, certificados, elogios etc.

4. Recompensas por parte do professor: atenção especial, tratamento diferenciado, participar de outras atividades com o professor etc.

Essas recompensas externas proporcionam métodos simples, diretos e práticos, por sua rápida percepção aos resultados da partida. Contudo, os educadores questionam o uso de fatores motivacionais externos, pois, quando relacionados com a aprendizagem, podem resultar em um aprendizado mecanicista (BORUCHOVITCH, 2004).

Para melhor compreender e visualizar as diferenças entre motivação intrínseca e extrínseca, Aguiar (2010) apresenta um quadro que ilustra uma tabela adaptada a partir dos conceitos propostos por Boruchovitch e Bzuneck e Malone e Lepper (1987):

\begin{tabular}{|l|c|c|}
\hline & $\begin{array}{c}\text { MOTIVAÇÃO } \\
\text { INTRÍNSECA }\end{array}$ & $\begin{array}{c}\text { MOTIVAÇÃO } \\
\text { EXTRÍNSECA }\end{array}$ \\
\hline $\begin{array}{l}\text { Promoção do interesse } \\
\text { do individuo }\end{array}$ & Estímulos internos & Estímulos externos \\
\hline Objetivos da atividade & Fim em si mesmo & Obter resultado \\
\hline $\begin{array}{l}\text { Recompensas ou punições } \\
\text { externas }\end{array}$ & Ausentes & Presentes \\
\hline $\begin{array}{l}\text { Relacionamento com a } \\
\text { aprendizagem }\end{array}$ & Integral & Arbitrário \\
\hline
\end{tabular}

Quadro 3. Quadro distinguindo as motivações intrínseca e extrínseca 
Portanto, por meio da motivação intrínseca, a participação do próprio aluno em seu processo de aprendizagem, configura-se como a recompensa principal, sem necessitar de apelações externas, internas ou premiações por seu cumprimento, mas isso não exclui os estímulos extrínsecos, questionados por educadores, que podem potencializar significativamente a motivação para a realização de uma determinada tarefa (BORUCHOVITCH, 2004).

Qualquer que seja a tarefa e o valor de sua experiência, os games educativos e simuladores proporcionam aos jogadores uma sensação de envolvimento e empolgação, que se sobrepõem a sensação de um trabalho árduo, sério ou até mesmo obrigatório.

Segundo Jane McGonigal (2012), esses tipos de trabalho assumem formas diferentes em tempos diferentes para cada indivíduo. E para atender a suas demandas individuais, há décadas os games tem se desenvolvido e oferecem cada vez mais tipos distintos de trabalho, como o:

- Trabalho de desafios - nos orienta à ação e nos empolga não apenas com a possibilidade de sucesso como também de um fracasso espetacular.

\section{Ex.: Gran Turismo}

- Trabalho de distração - é completamente previsível, entretanto nos ocupa a mente para uma atividade com um resultado claro.

Ex.: Farm Ville

- Trabalho mental - que potencializa nossas faculdades cognitivas nos fazendo pensar, tanto em games com partidas rápidas ou bem extensas.

Ex.: Age of Empires

- Trabalho físico - que nos exercita fisicamente.

Ex.: Dance Dance Revolution

- Trabalho de descoberta - que trata do nosso prazer de investigar de forma ativa objetos e espaços não familiares. Ao explorar misteriosos ambientes, como em games de RPGs.

Ex.: BioShock

- Trabalho em equipe - que enfatiza a cooperação em grupo.

Ex.: World of Warcraft

- Trabalho criativo - que trata de desenvolver um trabalho artístico a criação de casas ou personagens.

Ex.: The Sims 
Do trabalho como atividade do cotidiano ao trabalho profissional, os games de entretenimento e educacionais vem cumprindo vários papéis, com suas ferramentas individuais ou coletivas, jogando ou simulando, com motivação intrínseca ou extrínseca, favorecidos pela presença das TICS em casa e nas escolas.

Sobre essa relação dos games com o trabalho, segundo Prensky (2010), em 2004 foi apresentada uma tese da Universidade de Harvard, baseada em milhares de entrevistas, de que jogadores de games são executivos diferentes e mais bem-sucedidos que os demais, porque:

- São bons na solução colaborativa de problemas;

- Têm forte senso de competência;

- Adoram informações;

- Sentem-se confortáveis em assumir riscos calculados;

- Realizam bem várias tarefas;

- Aprendem de maneira dinâmica;

- Pensam globalmente;

- Esperam que as soluções provenham deles próprios.

Pois, então, nos questionamos, que games são esses que podem contribuir tanto para a educação e o preparo profissional dos alunos? A seguir, selecionamos e sugerimos alguns exemplos do que está disponível no mercado e na internet.

\section{2}

\section{Recomendações de games educativos}

O Brasil é o maior mercado de games da América Latina e o $11^{\circ}$ do mundo, segundo a Acigames (Associação Comercial, Industrial e Cultural de Games). Dados da Google mostram que há 54 milhões de gamers no Brasil, sendo que desse total, 46 milhões são jogadores online. Além disso, dos 100 maiores canais em número de assinantes, 29 deles são sobre jogos, alcançando 22 milhões de pessoas.

Apesar de apresentar esse potencial, o educador João Mattar (2010) comenta que o país não oferece os mesmos fomentos governamentais na produção de games de entretenimento como em outros países, e menos ainda para a produção 
de games educativos. Uma exceção é o Porto Digital, fundado em 2000, com sede em Pernambuco (Recife) e ramificações na Paraíba (João Pessoa e Campina Grande), onde sua atuação se dá em especial nos segmentos de games, multimídia, cine-vídeo-animação, música, design e fotografia. O empreendimento é fruto de uma ação coordenada entre indústria, governo e academia que resultou num dos principais ambientes de inovação do País.

Segundo Mark Prensky (2012), precisa existir uma integração entre o game e a aprendizagem, de forma que o jogador aprenda se divertindo ou se divirta aprendendo algo. Apesar de muitos pesquisadores tentarem, o game designer americano diz que não há uma só maneira, fórmula ou receita para conseguir essa integração, pelo contrário, é necessário um espaço para muito pensamento criativo.

Contudo, a maneira com que os games educativos estão sendo disponibilizados é bem variada, pois os games podem tanto estar disponíveis individualmente para serem jogados no computador, tablet, celular ou até mesmo em consoles. Também podem estar organizados em um único portal ou plataforma que contém dezenas de outros games de plataforma adaptativa que fornece estatísticas para alunos e professores. A seguir, comentamos sobre a peculiaridade das ferramentas digitais disponíveis no Brasil e no exterior para acessar os games educativos.

Nessa pesquisa, limitamos a cinco exemplos de cada tipo de ferramenta digital de games educativos, como uma amostragem dentre tantas disponíveis na rede. São elas: plataformas de games educativos, portal de games educativos, mini-games educativos, games educativos, games sérios e aplicativos para dispositivos móveis.

\section{Plataformas de games educativos}

É composta por diversos games e/ou mini-games vinculados a várias disciplinas do currículo escolar. São produtos com uma estrutura complexa, que oferecem plataformas adaptativas com auxilio de IA (inteligência artificial) ou com a apresentação de diversos níveis de dificuldade para cada game, permitindo que o aluno avance de acordo com a sua capacidade individual de aprendizagem, além de poder jogar o tempo que bem desejar para cada desafio. 
A plataforma registra informações da performance de cada aluno (algumas oferecem rankings) e gera relatórios estatísticos para que seus professores possam acompanhar o aprendizado, interesse e desenvolvimento de seus discípulos em cada game, os relatórios podem ser individuais, de classe, de toda série ou até mesmo de toda a escola. Há plataformas que oferecem uma interação com muitos jogadores simultaneamente (MMO - Massively Multiplayer Online).

(Brasil)

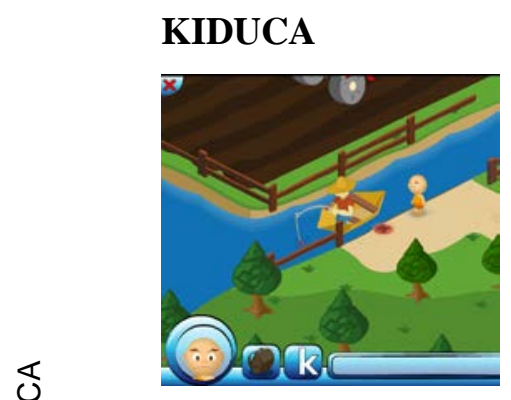

Figura 7

(Inglaterra)

MANGAHIGH

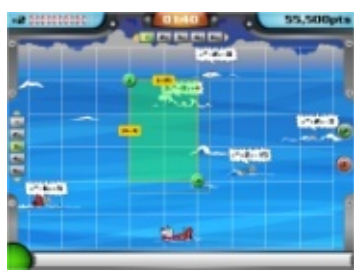

versão em português

Figura 8
$<$ http://www.kiduca.com.br/>

Plataforma educacional baseada em games no estilo MMO (Massively Multiplayer Online) que simula uma Cidade e seus bairros, sendo cada bairro uma área do conhecimento. Dentro da cidade, os alunos podem se encontrar para trocar informações e conhecimento online. Para estudantes de 6 a 14 anos, matriculados no Ensino Fundamental I e II.

$<$ https://www.mangahigh.com/pt-br>

Plataforma de recursos digitais que reúne games, quizzes e ferramentas de análise diagnóstica em tempo real. São 20 games de matemática com aproximadamente 50 mil desafios. No Brasil, a plataforma é aplicada através do Sistema SESI Matemática atendendo a 32 mil alunos, que até 2015 será expandido para o Sesi Nacional e para as 1,2 mil escolas da rede estadual carioca.

O professor de matemática Luiz Carlos Carvalho, do SESI Maracanã, utiliza essa plataforma para reforçar o aprendizado dos alunos e percebeu que, em média, eles tiveram suas notas aumentadas em um ponto. 
(Brasil)

OJE - Olimpíadas de Jogos Digitais e Educação

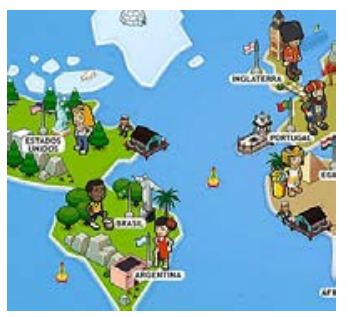

Figura 9

$<$ http://www.oje.inf.br/acre/app/index>

É uma tecnologia educacional lúdica, através da qual os alunos (do $8^{\circ}$ ano do Ensino Fundamental e do $1^{\circ}$ ao $3^{\circ}$ ano do Ensino Médio) e seus professores interagem em uma rede social virtual e colaboram na resolução de desafios baseados nos conteúdos da matriz curricular e acumulam pontos durante todo o ano letivo. Uma iniciativa da Secretaria de Educação do Estado de Pernambuco, a OJE funciona como uma rede social com games que desafiam os jogadores em uma aventura de RPG. Foi considerado o melhor jogo educativo da Games Show 2012, a maior feira de jogos da América Latina. Até 2013, a plataforma foi aplicada a 100 mil alunos, 4 mil professores de 2 mil escolas.

(Brasil)

VIVAZ

O jogo do conhecimento

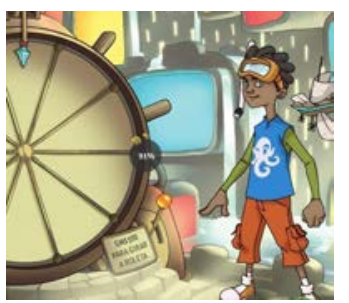

Figura 10
$<$ http://www.livrariasaraiva.com.br/>

Plataforma digital lúdica e adaptativa, é direcionada ao Ensino Fundamental ( $1^{\circ}$ ao $5^{\circ}$ anos). Desenvolvida pela Livraria Saraiva em parceria com a Tamboro, startup especializada em games educativos, Vivaz é uma plataforma gamificada que une o universo dos jogos aos conceitos da aprendizagem “adaptativa” - isto é, que se adapta às necessidades individuais de aprendizagem de cada estudante, direcionando sua trajetória dentro do jogo de acordo com seu desempenho, reforçando os conteúdos nos quais o aluno precisa se aprimorar. No banco de dados da Vivaz, estão mais de 10 mil questões nas principais áreas do conhecimento: Língua Portuguesa, Matemática, Ciências, Geografia e História. 
(Inglaterra)

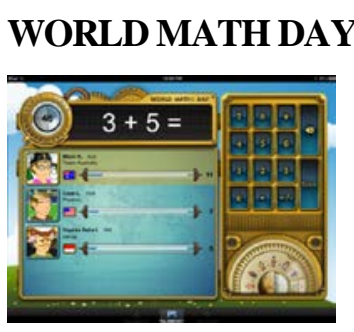

Figura 11 <http://www.3plearning.com/worldeducationgames/>

É o Dia Mundial da Matemática. É uma competição internacional de matemática on-line criada em 2007 com duração de apenas 24h, desenvolvida pela 3P Learning. Em 2011, a equipe incluiu um segundo evento, o Dia Mundial do Soletrar - oficialmente rebatizado como os Jogos Mundiais de Educação. Em 2012, um terceiro evento foi adicionado - Dia Mundial da Ciência. Os Jogos Mundiais de Educação estão agora patrocinado pela Samsung, e apoiada pela UNICEF como parceiro caridade global. Os Jogos Mundiais de Educação, envolvem mais de 4 milhões de estudantes de 240 países ao redor do mundo.

\section{Portal de games educativos}

São portais com diversos games voltados para a educação. Com o intuito de oferecer apoio ao professor e aos alunos, tanto em sala de aula como fora do ambiente escolar.

Em um portal, os games são organizados e classificados de forma que auxiliem tanto o aluno como o professor em identificar quais games os interessam buscando aderência ao seu currículo escolar daquele momento de seu ano letivo.

(Austrália)

ALBERTA GOVERNMENT

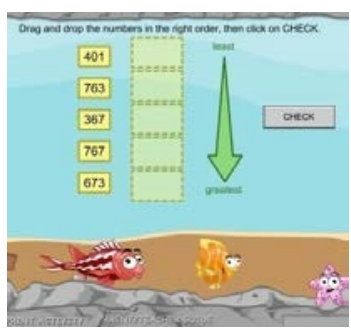

Figura 12
$<$ http://www.learnalberta.ca>

Portal australiano para o Governo de Alberta oferece dezenas de games educativos produzidos pelo Ministério da Educação, correlacionados ao currículo escolar da Educação Infantil ao Fundamental II. O design do site é um reflexo de como os professores pensam e trabalham em um ambiente online. 
(Brasil)

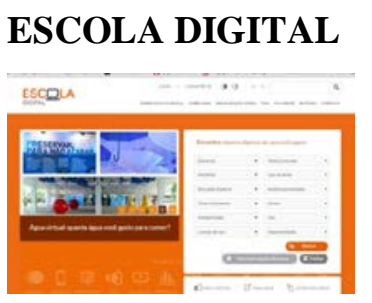

Figura 13

<http://escoladigital.org.br/tipo_midia/games/>

É uma plataforma de busca que reúne objetos e recursos digitais voltados a apoiar processos de ensino $\mathrm{e}$ aprendizagem dentro e fora da sala de aula. A indicação dos objetos é coletiva e atualmente esta na marca de quase 900 objetos digitais de aprendizagem, além de games tem links para vídeos, plataformas, animações, videoaulas, infográficos e mapas.

(EUA)

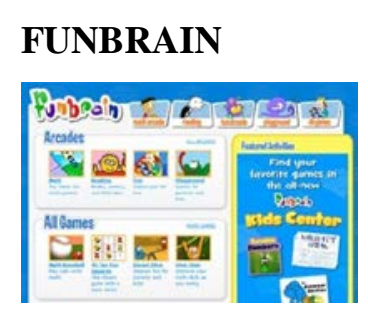

Figura 14

$<$ http://www.funbrain.com/>

Portal de games para alunos de Educação Infantil e Fundamental I. Oferece mais de 100 games interativos e divertidos que desenvolve habilidades em matemática, leitura e gramática. Seus games são recomendados como reforço escolar para ser praticado fora do horário escolar. Tem uma seção para o professor identificar os games que sejam compatíveis com o currículo.

(Brasil)

LUDO EDUCATIVO

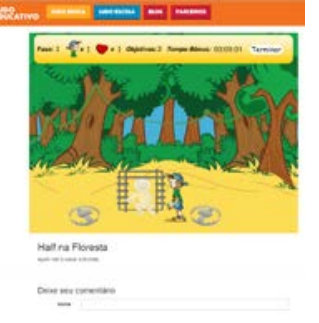

Figura 15

<http://portal.ludoeducativo.com.br/pt/>

Desenvolvido em parceria com a Fapesp, o portal reúne diversos jogos educativos com acesso gratuito nas áreas de saúde, cultura, lógica e meio ambiente. Em uma espécie de tabuleiro virtual, o jogador precisa conduzir o seu carro até o final, vencendo desafios que brincam com letras, palavras e sílabas. Foi um dos finalistas na categoria Jogos Educativos da Games Show 2012.

Ludo Educativo nasceu de uma iniciativa conjunta da Aptor Games e Centro de Desenvolvimento de Materiais Funcionais (CDMF), um dos 11 centros de excelência (CEPIDs) da FAPESP e o Instituto Nacional de Ciência e Tecnologia dos Materiais em Nanotecnologia (INCTMN). 
(Brasil)

MY MATH

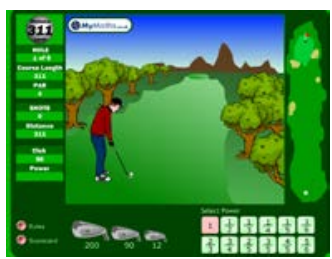

Figura 16

<http://www.mymath.co.uk/>

Este portal, com mais de 10 anos de prática, contém um considerável pacote de games que possibilita aos alunos consolidarem seus estudos de matemática, além de conteúdo digital para reforço escolar. Sua metodologia tem sido aplicada a mais de 3 milhões de alunos do Ensino Fundamental ao Médio, distribuídos em 70 países.

\section{Mini-games e jogos sérios educativos}

São objetos digitais de aprendizagem, dinâmicos e lúdicos, que apresentam temas específicos e seus conteúdos são pré-definidos. Variam de formato e estilo, e são baseados em desafios, estratégias e aventuras, podendo ter a estrutura de um mini game até um elaborado RPG (Role-Playing Game, que em português se traduz para "game de representação de personagens").

Diferente dos RPGs, devido ao seu simples formato, os mini games são mais encontrados em portais e plataformas educacionais do que isoladamente em algum sítio específico.

(Sueco)

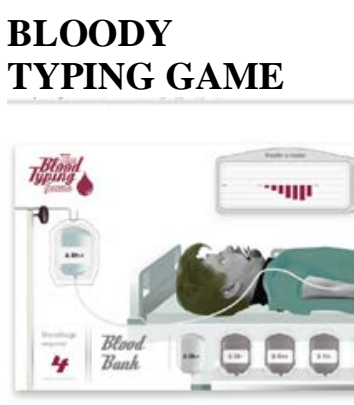

Figura 17 <http://www.nobelprize.org/educational/medicine/bloodtypinggame> Este mini game foi lançado em dezembro de 2011, foi criado para ensinar a identificar os tipos sanguíneos e administrar transfusões de sangue seguras. Você pode incorporar o jogo dentro do seu site, blog ou redes sociais e desafiar seus colegas. Seu trabalho é decidir o tipo de sangue a que esses pacientes pertencem, a fim de administrar transfusões de sangue seguras. Em 2012, foi Vencedor do Melhor Jogo Categoria Sueco Aprendizagem Awards. 
(Brasil)
CIDADE VERDE

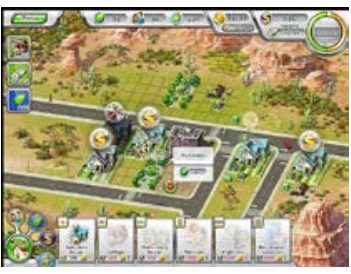

Figura 18

versão em português <http://pt.sheeparcade.com/cidade-verde-2/>

Lançado em 2010 pela Mother Gaia Studio, de alunos da Unesp de Bauru, foi premiada no exterior. O original City Rain ganhou uma versão gratuita em português, em 2011, destinada ao uso nas escolas públicas e privadas. No ambiente virtual, o aluno é um prefeito que deve construir sua cidade de forma sustentável, atendendo às necessidades sociais e desenvolvendo a economia com preocupação ambiental. Por meio de 20 desafios lúdicos, são abordados temas como mobilidade, coleta de lixo, tratamento de esgoto, desmatamento, consumo e gestão pública de gastos.

(Brasil)

MITO DA CAVERNA

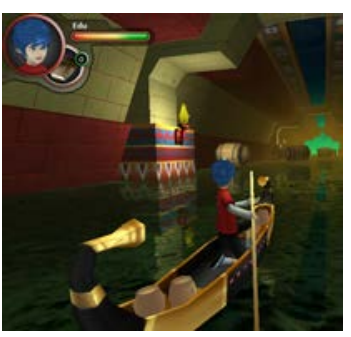

Figura 19

<http://www.omitodacaverna.com.br>

Considerado o melhor jogo educativo da edição 2011 da Games Show, a aventura em 3D se inspira na famosa parábola do filósofo Platão, que mostra como o ser humano pode se libertar da escuridão que o aprisiona por meio da luz da verdade. Voltado a estudantes do $1^{\circ}$ ao $5^{\circ}$ ano do Ensino Fundamental, são cinco games para cada ano, o conteúdo pedagógico do Mito da Caverna foi construído com base nos Parâmetros Curriculares Nacionais. São disponibilizados um Guia do Professor, que orienta como o jogo pode ser usado como prática educadora, e um sistema para avaliação e acompanhamento do aluno.

(Sueco)

OPERAÇÃO

$<$ http://redalgo.com/demoF.html>

Game educativo da Redalgo, lançado em 2008 e vencedor do prêmio NAVE 2009 de melhor game educativo, é um RPG, um game do gênero aventura, que aborda temas escolares do 


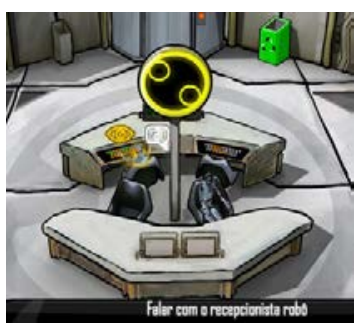

Figura 20

Ensino Fundamental I e II e pode ser utilizado durante todo o ano letivo, devendo ser jogado por partes, conforme o ritmo de duplas ou trios. O estudante vivenciará situações de cuidado com o meioambiente, lixo, reciclagem, poluição e recursos renováveis. O conteúdo pedagógico dos temas escolares abordados na história gera aulas complementares, permitindo o aprendizado através de temas transversais sugeridos no Guia de Orientações Pedagógicas destinado ao professor.

(Brasil)

TRÍADE

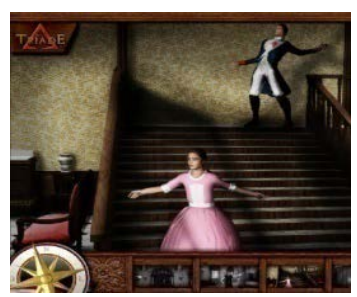

Figura 21 <http://www.clickjogos.com.br/downloads/triade/>

Desenvolvido em 2006, pelo Grupo de Pesquisas Comunidades Virtuais da Uneb, sob a coordenação de Lynn Alves. É um game, para o Ensino Fundamental II e Médio, no estilo adventure com elementos de RPG (RolePlaying Game, que em português se traduz para "jogo de interpretação de personagens") composto de uma narrativa que apresenta bifurcações. O game se passa durante a Revolução Francesa, ao final do séc. XVIII.

\section{Jogos sérios de entretenimento}

São games projetados e usados com o propósito de abordar as questões mais prementes do nosso tempo ou com a finalidade de treinar (simuladores) e experimentar suas consequências como na vida real. Um exercício mental, jogado com o computador com um conjunto de regras específicas que usam o entretenimento como base para sua metodologia.

À medida que as plataformas tecnológicas e os games foram se aperfeiçoando, os "serious games" têm sido aproveitados em uma grande diversidade de áreas: defesa, serviços de saúde, educação, exploração científica, religião, políticas públicas, gestão de emergência, engenharia e planejamento urbano. Com sua linguagem criativa, os jogos sérios têm sido comercializados em todo o mundo.

Contudo, alguns professores perceberam o potencial de alguns desses jogos para servir à educação, são aplicados dentro do ambiente escolar ou explorados 
pelos estudantes em seus momentos de lazer com o intuito de, ao mesmo tempo, aprender e se entreter.

O aprendizado por meio de jogos sérios e simulações surgiu com a demanda de militares na época da segunda grande guerra, obviamente com tecnologia e ferramentas pouco sofisticadas. A metodologia era utilizada para o treinamento de habilidades operacionais de equipamentos, o que evoluiu para os simuladores de voo e, posteriormente, para o treinamento de estratégias militares.

(Brasil)

CAPOEIRA LEGENDS

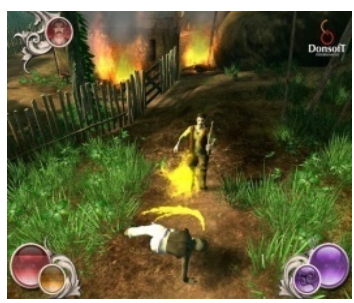

Figura 22

versão em inglês

(EUA)

\section{CIVILIZATION}

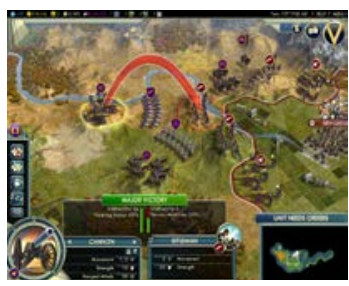

Figura 23

versão em português
- História -

<http://www.capoeiralegends.com>

A primeira obra, Capoeira Legends: Path To Freedom, é um jogo de ação e luta dividido em três capítulos. Lançado com versões em português e inglês para computadores desktop foi o grande vencedor de quatro prêmios Nave Oi Futuro de 2009, incluindo o de Melhor Jogo Nacional.

\section{- História e Ecossistema -} $<$ https://www.civilization.com> Lançado em 1991, chegou ao Brasil em 2005 e foi apresentado em sua quinta versão em 2014. 'E uma série de jogo de computador criado por Sid Meier do gênero de estratégia por turnos. O objetivo dos jogos da série é desenvolver um grande império desde o início, quando os primeiros homens deixam de ser nômades e constituem uma civilização. O jogo começa nos tempos antigos, o jogador vai evoluindo em sua civilização descobrindo por exemplo: a roda, literatura, energia, matemática, o bronze, o ferro, arquitetura etc. O jogador precisa expandir e desenvolver seu império através das eras até um futuro próximo. O jogador concorre com diversas outras civilizações que podem tornar-se aliadas ou inimigas. 
(Sueco)

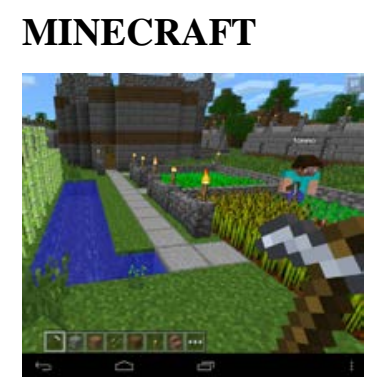

Figura 24

versão em português

- Geografia, Localização, Administração -

$<$ https://minecraft.net/>

Minecraft foi criado pelo programador sueco Markus "Notch" Persson em 2009 e, posteriormente, desenvolvido e publicado por Mojang .

Devido a seus aspectos criativos e de construção, Minecraft também tem sido utilizado em escolas, pois permitem aos jogadores fazer construções de cubos texturizados em um mundo processualmente gerado em 3D. Outras atividades do jogo incluem a exploração, reunindo recursos , minério, e combate. Vários modos de jogo estão disponíveis e um modo de aventura onde os jogadores podem criar mapas personalizados para outros jogadores.

Minecraft recebeu cinco prêmios. A partir de 25 de junho de 2014 , o jogo já vendeu mais de 12 milhões de cópias no Xbox 360 , 15 milhões de cópias no PC e cerca de 54 milhões de cópias em todas as plataformas .

(EUA)

THE SIM CITY

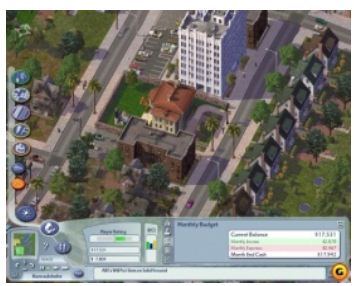

Figura 25

versão em português
- Ecossistema, Administração e Geografia $<$ http://www.simcity.com>

É um jogo de simulação da Maxis, subsidiária da Electronic Arts, criado pelo designer de jogos Will Wright em 1989. O objetivo básico do jogo é criar uma cidade e administrar bem os recursos dela para que ela não entre em falência e você, com o papel de prefeito. Você pode controlar uma região que oferece verdadeira escala multi- cidade e jogar uma única cidade ou até 16 cidades ao mesmo tempo, cada um com diferentes especializações. Sua última versão de SimCity 5 (Cities of tomorrow) apresenta uma plataforma multiplayer, acrescentando uma nova dimensão ao seu jogo como o seu impacto de decisões tanto na sua cidade como na sua 
região e cria novas formas de jogar, colaborando ou competindo para ganhar realizações com as cidades vizinhas (de sua gestão ou de outros jogadores).

(EUA)

\section{ZOO TYCOON}

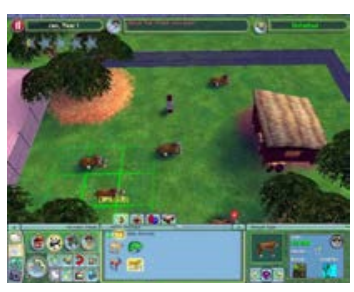

Figura 26

versão em português
- Ciências, Administração e Geografia $<$ http://zoo-tycoon.softonic.com.br/>

Lançado em 2001 para jogar no computador com o uso de CDs, em 2013 chegou uma versão ao Xbox One. É uma série popular de jogos para computador desenvolvida pela Blue Fang Games, na qual você constrói e cuida de um zoológico. Também há cenários onde você deve resolver problemas de vários zoológicos e atingir algumas metas. Você deve tornar o zoológico um bom ambiente para os visitantes e manter os animais felizes.

\section{Software de Autoria (Game Engine)}

São games editáveis, que permitem que tanto os professores quanto os alunos possam inserir informações, permitindo, assim, a autoria e originalidade da história e propiciando a aderência ao currículo escolar dos alunos no respectivo período.

Podem ser sofisticados softwares educativos, simples lições digitais editáveis ou plataformas com alguns mini-games engines opcionais. Assim como as plataformas mais complexas de games educativos, os softwares de autoria geram relatórios de acompanhamento da performance dos alunos para que os professores tenham o entendimento da situação de aprendizagem do seu grupo de alunos, individualmente ou coletivamente.

(Inglaterra)

\section{ABCya!}

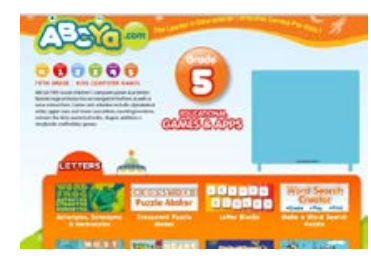

Figura 27 <http://www.abcya.com>

Criado por um professor em 2003, experimentalmente, e desenvolvido como um portal de games e game engine em 2006, o ABCya se tornou um dos mais famosos sites educacionais infantis e recebe mais de um 
milhão de visitas por mês.

ABCya! Oferece games e atividades para crianças de 4 a 9. Possuem botões de navegação grandes e fáceis de usar, bem como instruções de voz . Jogos e atividades incluem: ordem alfabética, com letras maiúsculas e minúsculas, ligar os pontos, ordem numérica, formas, adição, livros de histórias e games de férias. Alguns desses games podem ser editados pelo professor, a fim de dar mais aderência ao currículo.

(EUA)

\section{BRAINRUSH}

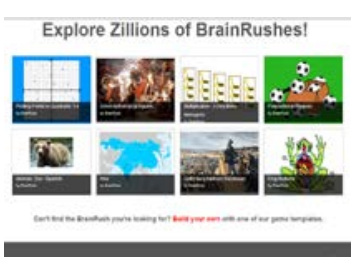

Figura 28
(Brasil)

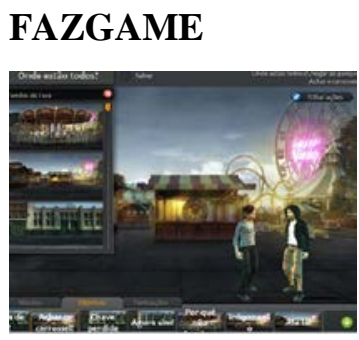

Figura 29
$<$ http://www.brainrush.com>

A plataforma foi desenvolvida por Nolan Busshnell, criador do Atari na década de 1970, e lançada no início de 2013. Conta com mais de uma centena de games, exercícios e testes condensados no ato de jogar, baseados em lições de matemática, química e geografia. Os jogos não duram mais do que 10 minutos. A plataforma também oferece a opção de ser customizada por professores que podem criar os seus próprios games. Além disso, existe uma plataforma de monitoramento dos alunos que oferece informações variadas sobre cada estudante de uma sala, como o tempo em que cada um demora a responder as ações. Nolan defende que o desempenho escolar do aluno melhora se ele jogar ao menos 15 minutos por dia.

<http://www.fazgame.com.br/>

Lançado em 2014 pela TecZelt, esse software é um game para criar games educacionais, que apresenta um ambiente lúdico e intuitivo, permitindo a professores e alunos, sem conhecimento de programação ou design, criar games motivadores de aprendizagem. Com o Faz Game, os alunos criam seus projetos de forma colaborativa junto com seus professores, desenvolvendo a escrita criativa, raciocínio lógico e a 
capacidade de solucionar problemas. Monitora o uso dos alunos e a complexidade dos games criados, fornecendo informações sobre a evolução dos alunos nos projetos de construção de games.

(EUA)

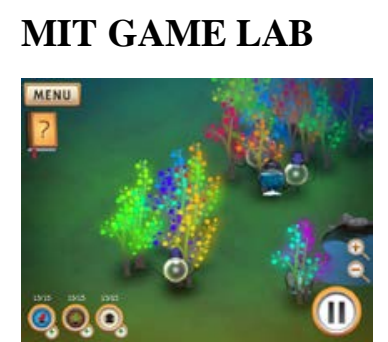

Figura 30
$<$ http://gamelab.mit.edu/>

É um software, que coloca juntos alunos, criadores e técnicos para ensinar e conduzir pesquisas a novas aplicações para o design e a construção de games. A missão é explorar, educar e envolver o público através da criação de jogos inovadores, cursos on-line interativos e novas aplicações para os desafios do mundo real.

(Inglaterra)

SMART NOTEBOOK

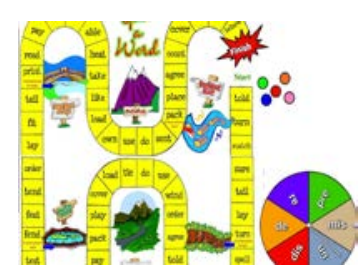

Figura 31 <http://www.education.smarttech.com/?wt.ac=homepage_ed $>$

É uma biblioteca online que oferece mais de 60.000 lições e recursos de aprendizado gratuitos e de alta qualidade. Também aproveita o conteúdo adicional criado pelos mais de 3 milhões de usuários do SMART Notebook.

Esse é o software de aprendizado colaborativo número 1 do mundo, pois permite que os professores criem aulas de alto impacto, acessem conteúdo educacional de alta qualidade e envolvam os alunos com um aprendizado interativo no computador e mais ainda em atividades específicas em quadros inteligentes.

\section{Aplicativos de games para dispositivos móveis}

Foi em 2010 que a abreviação de aplicativo, “app”, se tornou tão popular que foi assinalada como "Palavra do Ano" pela American Dialect Society. Originalmente os aplicativos móveis foram criados e classificados como ferramentas de suporte à produtividade e à busca por informação generalizada em aparelhos de telefonia móvel, incluindo correio eletrônico, calendário, contatos, informações meteorológicas entre outras do gênero. No entanto, os aplicativos 
voltados para o entretenimento como games e outros voltados para a música, também evoluíram incrivelmente. De acordo com a Portio Research (março de 2013) até o final de 2012, 1,2 bilhões de pessoas em todo o mundo utilizaram aplicativos para dispositivos móveis. Projeta-se que esta tendência cresça a 29,8\% por ano, atingindo 4,4 bilhões de usuários até o final de 2017.

Nos últimos três anos, foi notável o crescimento do mercado de games para dispositivos móveis, como celulares (smartphones), e tablets. Cresceu tanto que hoje já é um dos mais lucrativos para a indústria mundial dos videogames, devido ao seu baixo custo de produção. Nesse contexto, o Brasil aparece como um dos mercados mais promissores por conta do exepcional número de aparelhos celulares em atividade no país: cerca de 180 milhões.

A cada ano, aumenta a procura por jogos para dispositivos móveis. Em 2012, o número de jogadores ativos no Brasil já era de 40,2 milhões, sendo 28 milhões (70\%), em dispositivos móveis. Foram gastos US\$ 285 milhões (cerca de R\$ 672 milhões) em jogos para tablets e smartphones, e US\$ 2,6 bilhões (R\$ 6,1 bilhões) somando todas as plataformas (consoles, MMO Games, PC/Mac), um aumento de 32\% em relação a 2011. Com o avanço da tecnologia, os dispositivos móveis já suportam jogos complexos, de alta resolução, e por seu custo de produção muito menor em relação aos consoles como Playstation e XBOX, tem ganho cada vez mais produtores - e automaticamente mais usuários.

(Brasil)

ABC WORDS

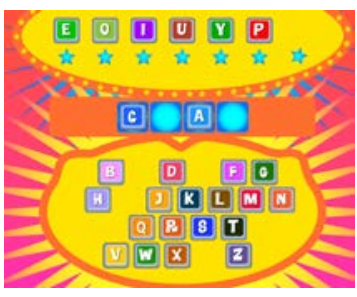

Figura 32
$<$ http://www.technolio.com/>

A Technolio é uma empresa que se dedica ao desenvolvimento de aplicativos educativos para crianças, para iPhone, iPad, Nook e Kindle em diferentes idiomas, como em Português (do Brasil), Espanhol e Inglês. A Technolio oferece aos pais os melhores joguinhos infantis, nos quais suas crianças vão se divertir e aprender ao mesmo tempo. Desde 2009, criaram 8 games educativos e 6 ibooks. 
(EUA)

\section{ALPHABET \\ CAR LITE}

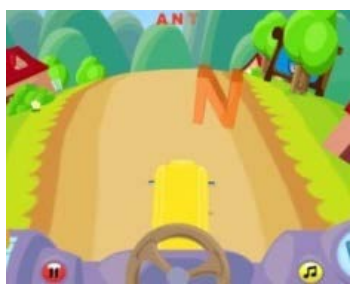

Figura 33

$<\mathrm{http}: / /$ www.famigo.com>

Game para dispositivos móveis, foi desenvolvido pela empresa americana Famigo, que tem um site, em que recomenda os melhores jogos e aplicativos educacionais para crianças. O game Alphabet Car Lite oferece ao jogador que está se alfabetizando uma divertida dinâmica de selecionar letras que aparecem ao longo da estrada, e formar palavras de 3 letras com elas.

(EUA)

\section{CUT THE ROPE}

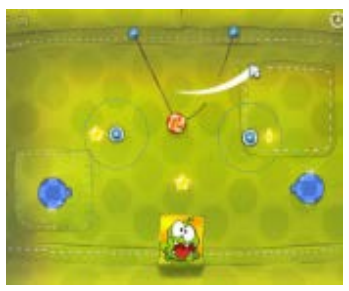

Figura 34

<http://www.zeptolab.com/games/cut_the_rope/>

É um jogo eletrônico de quebra-cabeça desenvolvido pela ZeptoLab lançado em 2010 para dispositivos com iOS, e em 2011 para Android. O jogo teve mais de 400 milhões de downloads em todas as plataformas (segundo a Google Play). A premissa é simples : cortar a corda e soltar alguns doces para alimentar a personagem criatura do game. As leis da gravidade estão presentes na dinâmica do game. O jogo apresenta diversos níveis de dificuldade e novas versões de cenário.

(Brasil)

\section{LETROCA}

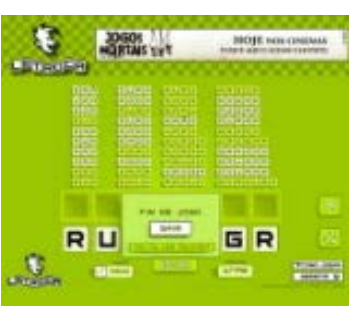

Figura 35
$<$ http://www.letroca-game.com>

É um divertido jogo de palavras disponível online, desde 2003. Em 2013, Rogerio Silberberg, sócio da Fanatee, lançou as versões para dispositivos Android e iOS. O objetivo do game é formar o maior número possível de palavras a partir de determinadas letras. O site disponibiliza 12 diferentes games da empresa, incluindo o tradicional Letroca. 
(Suécia)

TOCA TEA PARTY

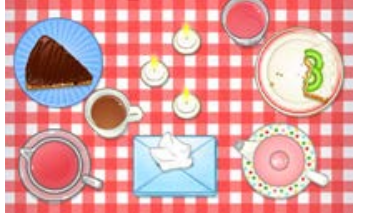

Figura 36 <http://tocaboca.com/game/toca-tea-party/>

Desde 2011, os games da Toca Boca, que no total já registraram mais de 70 milhões de download, foram apenas superados pela Walt Disney. Com versões em Android e IOS

\begin{tabular}{|c|c|c|c|c|c|}
\hline \multicolumn{6}{|c|}{ RECOMENDAÇÃO DE GAMES EDUCATIVOS } \\
\hline $\begin{array}{c}\text { Plataformas de } \\
\text { Games } \\
\text { Educativos }\end{array}$ & $\begin{array}{l}\text { Portal de Games } \\
\text { Educativos }\end{array}$ & $\begin{array}{c}\text { Mini-games e } \\
\text { Jogos Sérios } \\
\text { Educativos }\end{array}$ & $\begin{array}{l}\text { Jogos Sérios de } \\
\text { Entretenimento }\end{array}$ & $\begin{array}{c}\text { Software } \\
\text { de Autoria } \\
\text { (Game Engine) }\end{array}$ & $\begin{array}{c}\text { Aplicativos } \\
\text { de games para } \\
\text { Dispositivos } \\
\text { Móveis }\end{array}$ \\
\hline Kiduca & Alberta Government & Blood Typing Game & Capoeira Legends & AВСуа & Abc Words \\
\hline Mangahigh & Escola Digital & Cidade Verde & Civilization & Brain Rush & Alphabet Car Lite \\
\hline OJE & Funbrain & Mito Da Caverna & Minecraft & Fazgame & Cut The Rope \\
\hline Vivaz & Ludo Educativo & Operação Cosmos & The Sim City & Mit Game Lab & Letroca \\
\hline World Math Day & My Math & Tríade & Zoo Tycoon & Smart Notebook 11 & Toca Tea Party \\
\hline
\end{tabular}

Quadro 4. Quadro de Recomendação de Games Educativos e afins

Além dos games e plataformas apresentados por segmento e formato, segue mais alguns games sérios, listados por Prensky (2010) e Schwartz (2014), que podem auxiliar e estimular o aluno nas seguintes disciplinas ou temas transversais:

Biologia (evolução) - Spore <htpp://www.spore.com>

Ciências (aquecimento global) - Climate Defense

$<$ htpp://www.play.google.com/store/apps/details?id=org.aurochdigital.gamethenews $>$

Aplicativos de games para Dispositivos Móveis

Ciências (ecologia) - Sim Earth

$<$ htpp://www.freegameempire.com/games/SimEarth>

Física (mecânica) - The Incredible Machine

<htpp://www.techspot.com/downloads/5852-the-incredible-machine-2>

Física (energia) - Ludwig <htpp://www.playludwig.com/pt-br>

Geografia - Conflitos Globais

<htpp://www.conflict-global-storm.softonic.com.br/download>

História - Age of Empires <htpp://www.ageofempires.com/>

Inglês - Fun Test It <htpp://apps.facebook.com/funtestit/>

Química - Space Chem <htpp://www.zachtronics.com/> 


\title{
4.3
}

\section{Eventos de games educativos no Brasil}

No Brasil, a mídia e o mercado digital passaram por grandes transformações nessa última década, e alguns eventos comerciais, que já existiam, acompanharam essas mudanças enquanto outros surgiram nesse processo de aquecimento do mercado de games, segundo o Instituto Newzoo (UOL), que coloca o Brasil como o maior mercado do gênero da América Latina. Na comparação mundial, o país se tornou o $11^{\circ}$ maior mercado de games. Como a demanda por objetos de aprendizagem digitais é cada vez maior, os projetos de games educativos vão ganhando destaque nos eventos de games, assim como em eventos voltados para a educação. Ainda não há um evento ou associação especifica só para games educativos.

A seguir, apresentamos as instituições e eventos voltados para o fomento de games no Brasil, alguns desses com exclusiva ênfase no campo da educação:

\begin{abstract}
ABRAGAMES <http://www.abragames.org/>
Criada em 2004 por um grupo de empresas de desenvolvimento, a Abragames, Associação Brasileira dos Desenvolvedores de Jogos Digitais, única associação do gênero no país, surgiu como uma entidade sem fins lucrativos e com o objetivo de fortalecer a indústria nacional de desenvolvimento de games.
\end{abstract}

Big Festival <htpp://www.bigfestival.com.br>

É o primeiro festival independente de games da América Latina desenvolvedores independentes do mundo inteiro podem enviar seus games ao BIG. Lançado em 2013, teve suas duas edições anuais organizadas em São Paulo no mês de maio. São oferecidos prêmios nas categorias de melhor game, revelação Brasil, som, arte, narrativa, game play e prêmio do público!

Brasil Game Show <http://www.brasilgameshow.com.br>

A Brasil Game Show (ou BGS) é uma feira anual de videogames organizada pelo empresário Marcelo Tavares, voltada para o mercado comercial de games de entretenimento. A primeira feira ocorreu em 2009, no Rio com a presença de 4 mil visitantes, e a cada ano tem surpreendido com sua significativa 
expansão. Em 2014, será realizada em outubro, em São Paulo, e são aguardados 250 mil visitantes. A feira é considerada a maior conferência do gênero em toda a América Latina.

Bett Brasil Educar <htpp://www.bettbrasileducar.com.br/>

O evento Educar Educador que desde 1993 é o ponto de encontro entre educadores e distribuidores de produtos e serviços ligados à educação do Brasil e da América Latina somou-se à Bett Show em 2014, que é um congresso de tecnologia educacional com eventos na Europa, Ásia e América do Sul, e se transformou em Bett Brasil Educar atraindo milhares de pessoas em um encontro dedicado ao segmento da educação. O empreendimento conta com a participação de profissionais, técnicos, empresas e instituições nacionais e internacionais, tanto em suas inúmeras palestras quanto nos stands. Em 2014, o evento ocupou uma área reservada com mais de $11 \mathrm{mil} \mathrm{m}^{2}$ e a presença de mais de 300 empresas de diferentes partes do mundo.

Games4change <http://www.gamesforchange.org/>

Fundada em 2004, Games for Change é uma instituição sem fins lucrativos, que fomenta a criação e distribuição de games de impacto social e que servem como ferramentas importantes nos esforços para transformar positivamente a sociedade, a educação, a economia, o ambiente e a cultura.

Para investir no crescimento desse campo do conhecimento, Games for Change reúne várias partes interessadas, destaca as melhores práticas, incuba games, e ajuda a criar e a desenvolver novos projetos.

Em 2011, estabeleceu uma representação no Brasil sob a direção de Gilson Schwartz, professor do Departamento de Cinema, Rádio e TV da ECA-USP. Também tem representações na Europa, na Coréia e em Israel.

SBGames <http://www.sbgames.org>

O SBGames (Simpósio Brasileiro de Jogos e Entretenimento Digital) reúne anualmente pesquisadores, artistas, designers, professores e estudantes de universidades, centros de pesquisa e da indústria de jogos. SBGames é organizado pela Comissão Especial de Jogos e Entretenimento Digital da SBC (Sociedade Brasileira de Computação) e também é apoiado pela ABRAGAMES. O Simpósio 
começou em 2002 com o nome Wjogos, focado principalmente em computação, e desde então vem ocorrendo anualmente em diferentes cidades brasileiras no início de novembro. Ao longo dos três dias de Simpósio, além dos stands das empresas e instituições, são apresentados dezenas de projetos, teses e dissertações em torno dos games.

O SBGames também sedia a Gelly Jam (lançada em 2013), que é um desafio para desenvolvedores criarem um game educativo em apenas três dias.

A cada ano vem surgindo mais títulos individuais ou portais de games educativos, além de games de entretenimento ou sérios que estão voltados para o mercado comercial, que devido a habilidades e competências demandadas ao jogador, também podem ser utilizados como educativos.

Contudo, os professores, estudantes e seus pais que desejam utilizar games educativos têm dificuldades de identificar quais os games que podem contribuir para o aprendizado do aluno. Para favorecer a identificação dos games é \్ necessário que sejam classificados a partir de dezenas de variáveis.

A seguir, apresentamos uma proposta de organização e classificação para proporcionar essa identificação. 


\section{5.}

\section{Taxonomia de games educativos}

A taxonomia dessa pesquisa se propõe a classificar games educativos a fim de auxiliar professores, alunos e até seus respectivos pais a identificarem games que possam contribuir para a aprendizagem dos estudantes. A taxonomia aqui proposta é fluida, e de acordo com a abordagem da presente pesquisa, sempre haverá a possibilidade de inclusão e subtração de itens, conforme as TICs evoluam com seus hardwares e softwares, pois, consequentemente, surgirão novidades no desenvolvimento de games educativos.

Da mesma forma, o game designer americano Chris Crowford, em meados dos anos 1980, ao tratar de sua visão taxonômica em relação aos games, comentou:

Não tenho a pretensão de que a taxonomia proposta seja a correta, nem vou aceitar a alegação de que qualquer taxonomia correta pode ser formulada. A taxonomia é apenas uma maneira de organizar um grande número de objetos relacionados. (Crowford, 1986, p.26)

Podemos categorizar os games educativos de diversas maneiras, de acordo com Prensky (2010), ao comparar variáveis que nos fazem entender o quão diversa e criativa são as possibilidades de desenvolvimento de games voltados para o aprendizado, chegamos às destoantes possibilidades, como:

- Game online versus game carregado (download)

- Game impresso (pronto) versus software de autoria (editável)

- Game reflexivo versus game de ação

- Game para um jogador versus dois jogadores versus inúmeros jogadores

- Game com aderência ao currículo versus game de aprendizagem periférica

- Game educativo versus game de entretenimento versus game sério

- Game com uma única rodada versus game de níveis

Partindo dessas variáveis do design de games, contrapostas acima, para que seja produzido games educativos de qualidade, envolventes e eficientes é fundamental amalgamarmos mais de um campo de conhecimento como foi citado no sub-capítulo “Games na educação” (p.62).

Para compor essa taxonomia, além de identificar variáveis do campo do design, tecnologia e educação, houve um exercício para se incluir alguns itens da psicologia como, por exemplo: os tipos de inteligência ou estilo de aprendizagem 
(cinestésica, musical, lingüística etc.) (MATTAR, 2010), estilo cognitivo (raciocínio, processamento e memória) e estrutura de pensamento (sensorial, expressividade, visão do mundo etc.) (MAMMEDE, 1999). Dos quais, para a primeira montagem, foram selecionados os tipos de inteligência.

Após a montagem foi aplicado um teste, a fim de checar se as centenas de games pesquisados estariam contemplados com as variáveis da montagem 1. Essa dinâmica foi base para dar continuidade à composição de taxonomia ideal para esse estudo. Preocupando-se em iniciar com itens mais abrangentes até identificarmos itens mais detalhados. Como podemos observar a seguir:

MONTAGEM 1

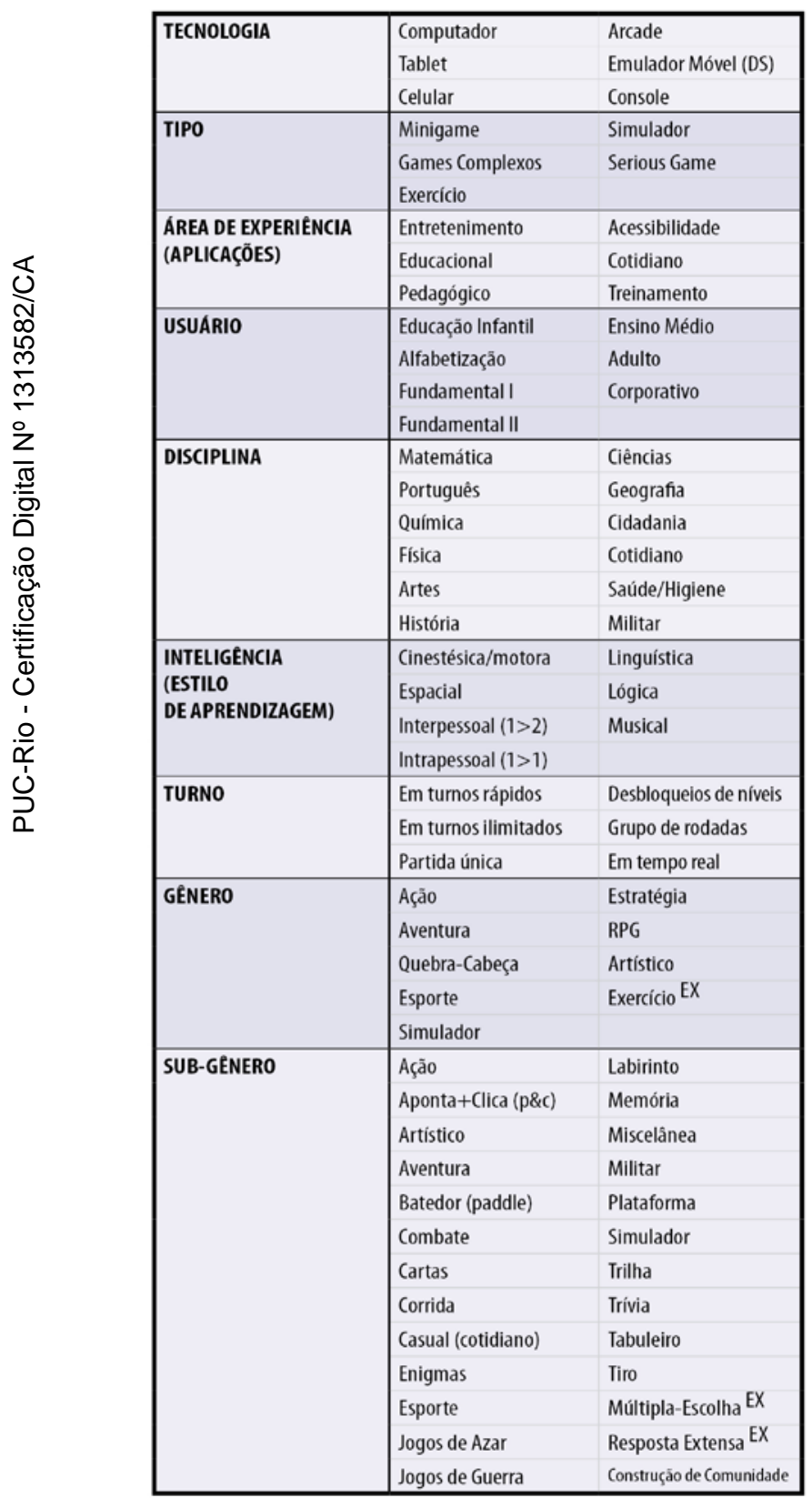

TESTE
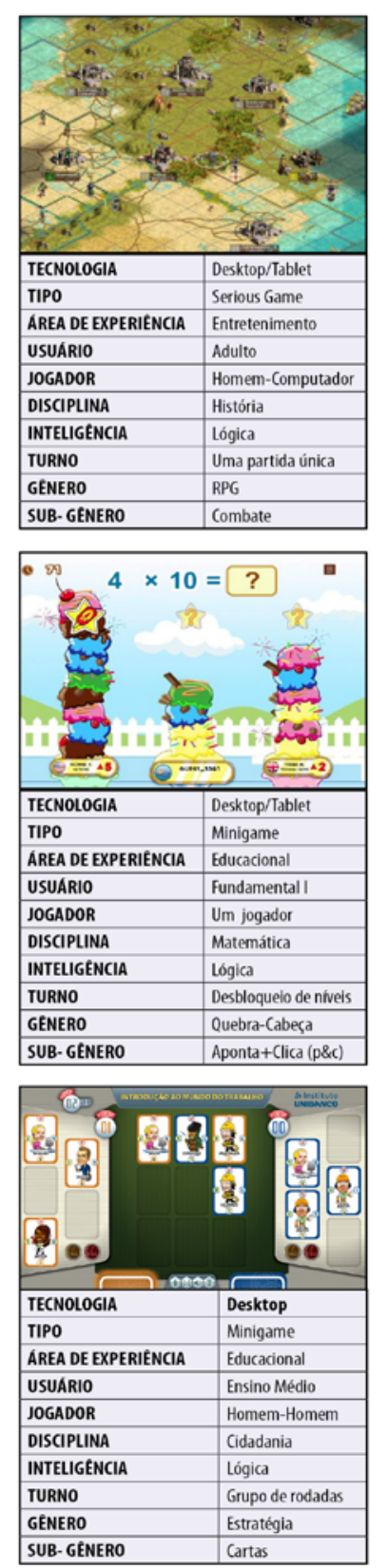

Diagrama 15. Processo de montagem taxonômica com teste de classificação Fonte: $\mathrm{O}$ autor 
Em seguida, percebeu-se que os dados do campo da psicologia são informações pertinentes para um pedagogo, entretanto, para que a taxonomia de games educativos contribua como informação para professores e alunos é necessário que ela seja composta de itens menos teóricos e mais práticos. Com isso, descartaram-se os tipos de inteligência e incluiu-se a base de dados, os direitos autorais e o tipo de acesso.

Para auxiliar na ordenação dos itens, eles foram reorganizados em sete segmentos, colocando como prioridade a área do conhecimento, conforme pode ser observado no diagrama a seguir:

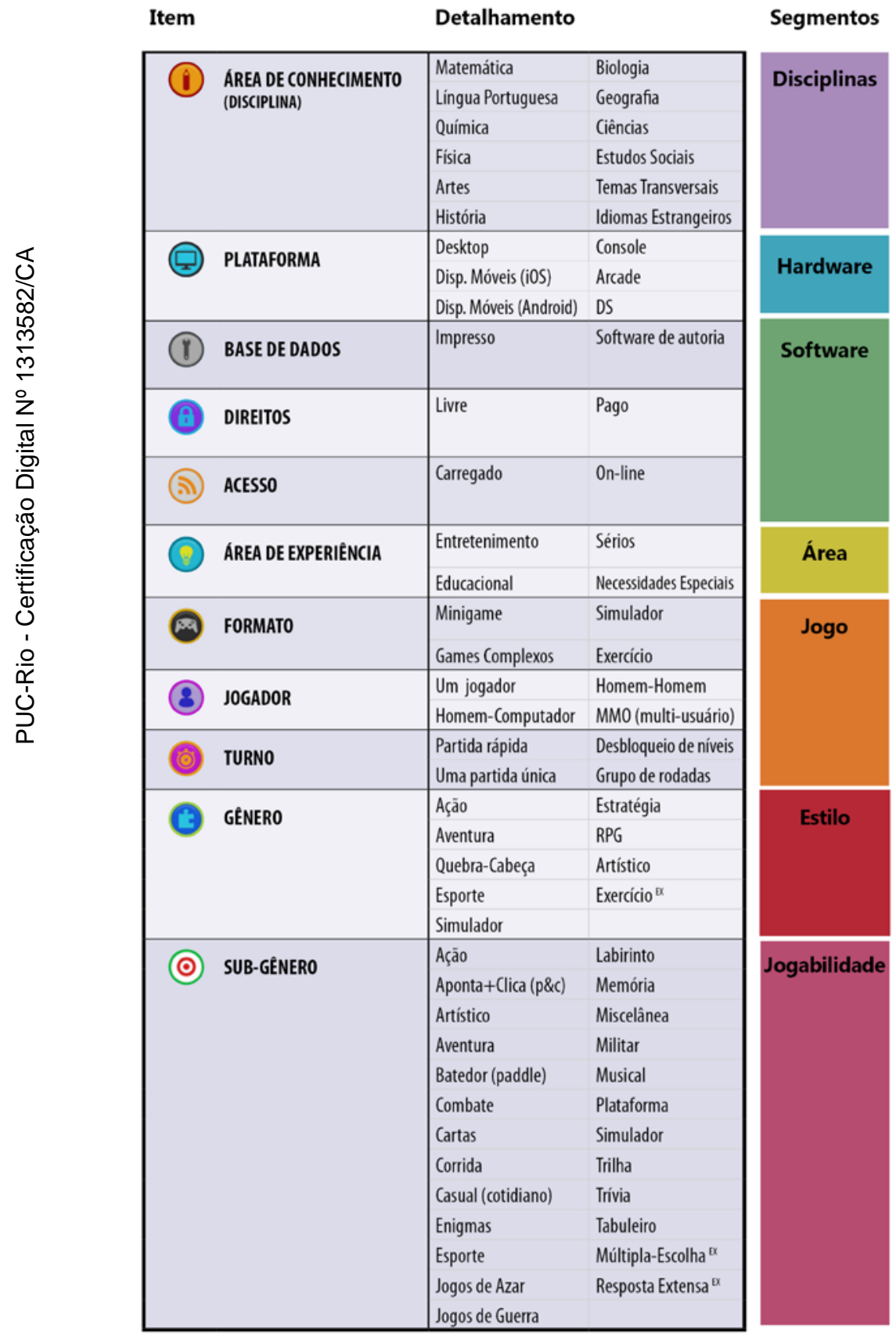

Diagrama 16. Processo de montagem taxonômica com segmentos Fonte: $\mathrm{O}$ autor 
Para alcançar o nível de organização e detalhamento dessa taxonomia, foi necessário praticar constantemente o teste do diagrama 15 (p.135) para se chegar a mais expressiva nomenclatura a cada segmento, item e detalhamento.

Para propiciar um melhor entendimento sobre o conteúdo da qual estamos tratando, a pesquisa desconstruiu a tabela anterior (diagrama 16) para construir um organograma, o qual serviu como auxílio para que fossem feitas novas avaliações sobre a ordenação e harmonização de nomenclaturas. Consequentemente houve uma nova rodada de testes, o que proporcionou uma revisão dos gêneros, além de que mais subgêneros foram identificados, aumentando de 25 para 29 dinâmicas para os games educativos.

A seguir, o estudo apresenta o modelo da taxonomia em forma de organograma, a propósito, as cores foram aplicadas para auxiliar no entendimento e prioridade de cada segmento:

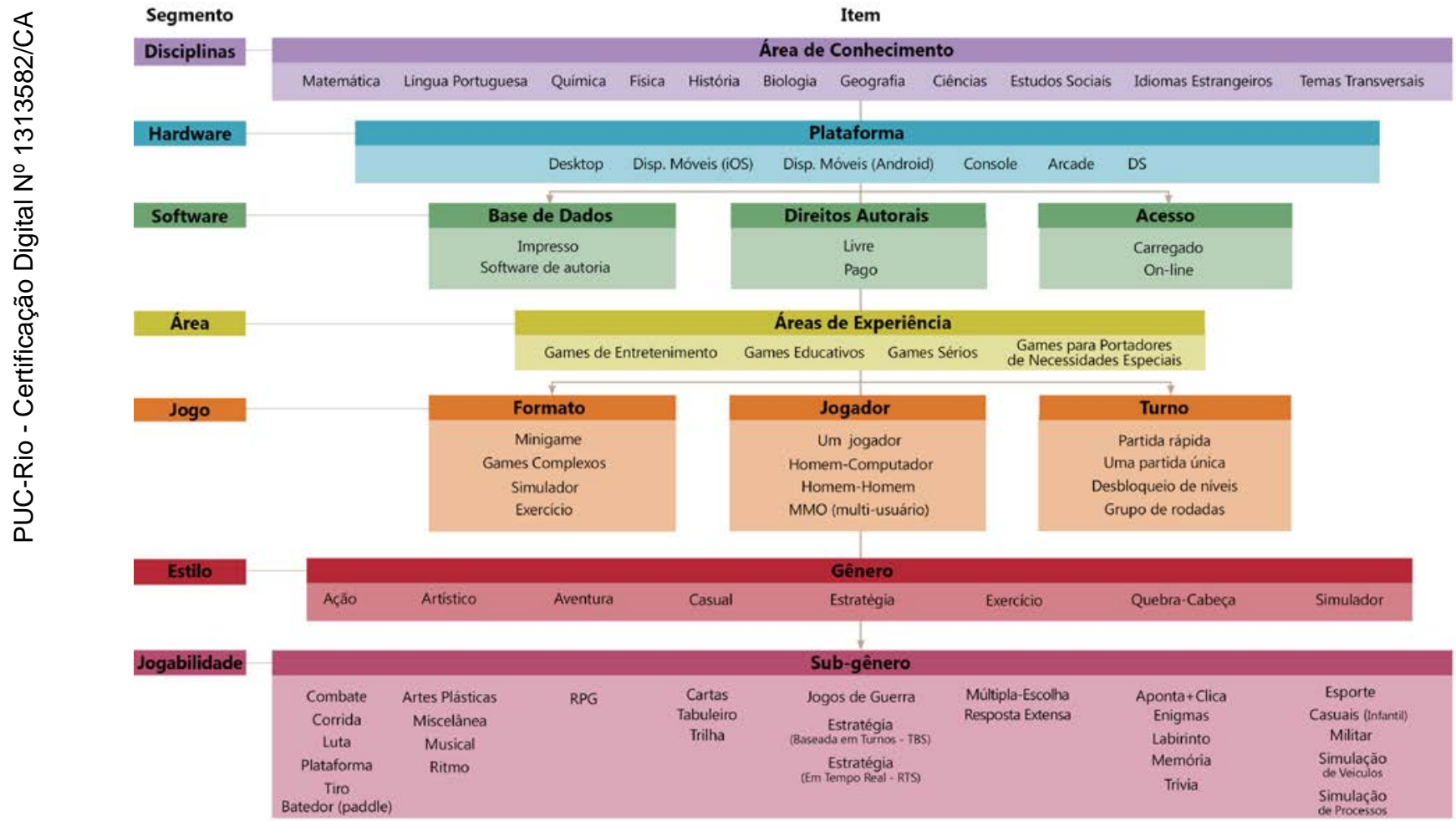

Diagrama 17. Processo de montagem taxonômica em forma de organograma

Fonte: $\mathrm{O}$ autor 
Apesar dos testes e das várias formatações da taxonomia dessa pesquisa até o momento, somente nessa etapa ficou evidente a necessidade de colocar a área de experiência como prioridade, devido à demanda pela identificação de games para portadores de necessidades especiais. Além disso, foi incluído o nivelamento do conteúdo com a inclusão da faixa etária conforme os segmentos educacionais estabelecidos pelo MEC.

No segmento que trata da estrutura do software, foi incluído o item de idiomas. O tratamento para exercícios digitais foi retirado do item formato para se constituir como gênero de game o que elevou o número de dinâmicas de 29 para 34, como apresentado no organograma a seguir:

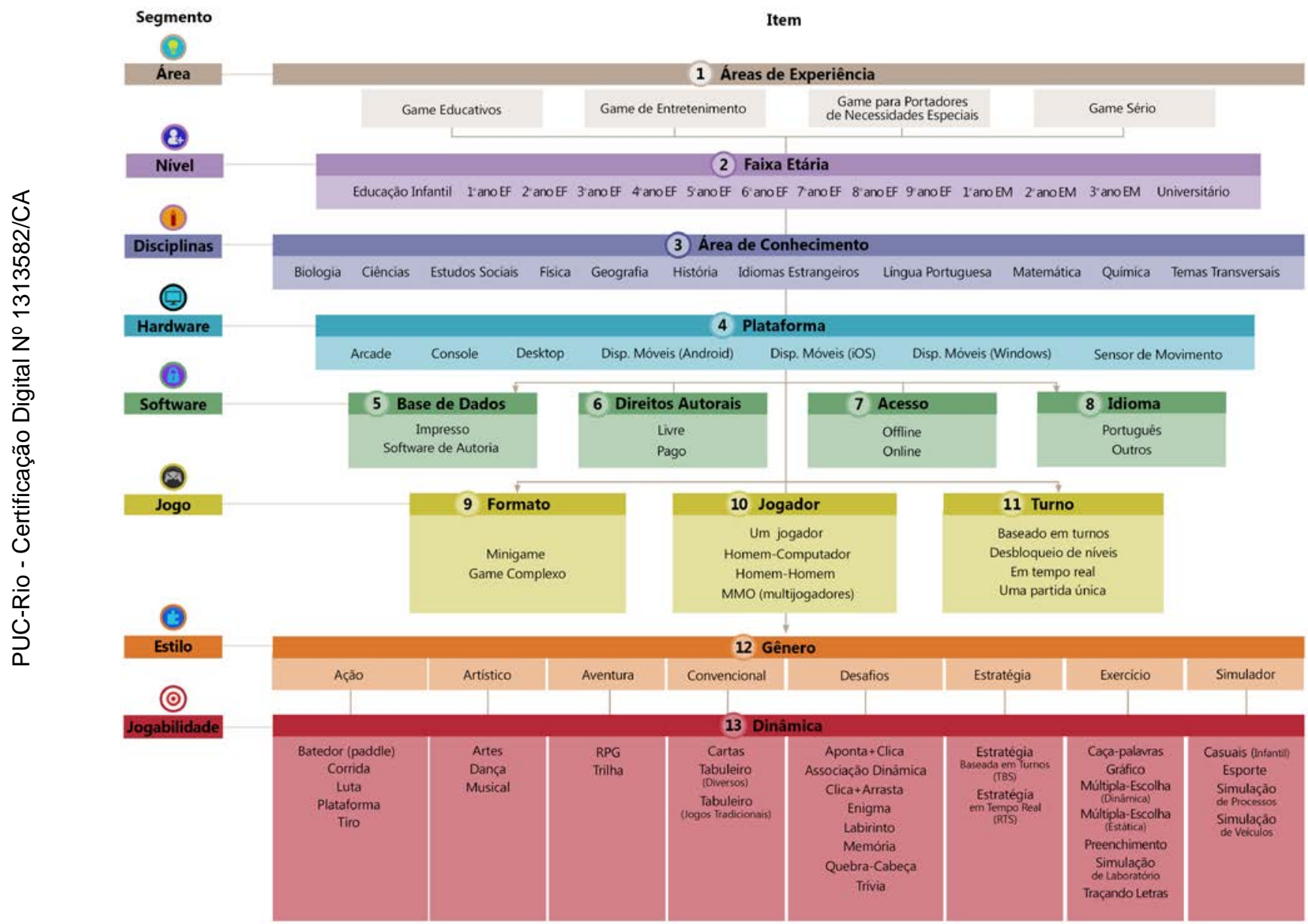

Diagrama 18. Taxonomia de Games Educativos Final Fonte: $\mathrm{O}$ autor

A seguir, a pesquisa explicita cada segmento, item e detalhamento apresentados na taxonomia de games educativos para melhor compreensão da nomenclatura estudada, avaliada e classificada nesse estudo. 


\section{Área de Experiência (Item 1)}

Os games que podem ser aplicados como objetos digitais de aprendizagem não estão restritos apenas à categoria dos educativos, pois tanto games comerciais e populares de entretenimento como os games sérios podem propiciar o desenvolvimento de alguma habilidade ou competência que tenha aderência ao currículo escolar do aluno.

Em se tratando do escopo dessa pesquisa, voltada para educação e aprendizado, podemos dividir o universo dos games em quatro distintas áreas de experiência que podem contribuir para o desenvolvimento educacional dos estudantes.

Vale registrar, contudo, que em princípio, os games excluem uma parcela de potenciais usuários e estudantes que são portadores de necessidades especiais. Apesar disso, alguns especialistas da área têm investido em desenvolvimento de games para portadores de deficiências visuais, auditivas, motoras e cognitivas e têm percebido excelentes resultados devido ao potencial adaptativo e interativo dos games. Para tal direcionamento, a Associação Internacional de Desenvolvedores de Jogos (IGDA), segundo Novak (2012), constituiu um Grupo de Interesse Especial de Acessibilidade em Games, presidido por Michele Hinn.

As quatro particularidades de games aplicados à educação, são:

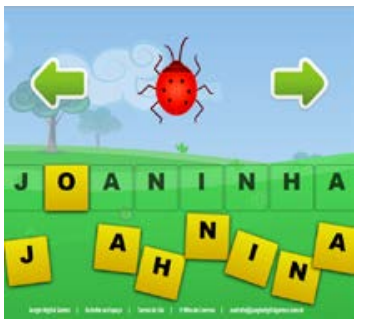

Figura 37

Turma do Lilo

\section{Games Educativos}

Os games educativos, em sua maioria, são criados para ensinar enquanto distraem. Esse tipo de game inicialmente foi desenvolvido, conforme citado no capítulo 2.3, somente para o público infantil (Educação Infantil e Ensino Fundamental) entretanto a demanda para estudantes de outros segmentos escolares tem aumentado muito nos últimos tempos. A educação formal é a meta específica para a aplicação desse tipo de game e pode-se considerar que todo game educativo apresenta alguma aderência ao currículo escolar. Os games de entretenimento também são utilizados por docentes nas escolas, devido a alguma particularidade específica que propicie o ensino de alguma área de conhecimento. 


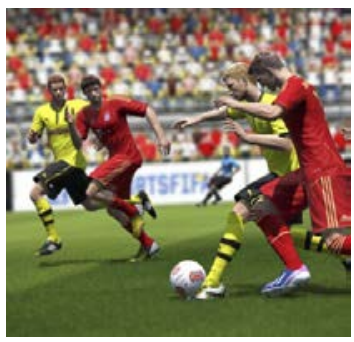

Figura 38

FIFA 2014

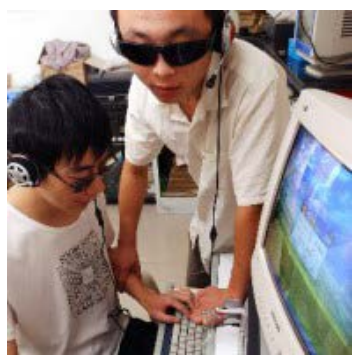

Figura 39

Audiogames.net
Os games educativos que apresentam aderência integral a uma determinada disciplina, tem um perfil mais voltado para um exercício digital do que propriamente a uma dinâmica com jogabilidade e entretenimento, mas também são considerados games.

Esses tipos de games propiciam um aprendizado curricular informal e lúdico a partir de um ambiente digital, podendo ser jogado tanto no ambiente escolar como no doméstico.

\section{Games de Entretenimento}

Desenvolvidos meramente para entreter os jogadores, como comentamos no capítulo 2.3, é o mais popular entre os gêneros de game. Propicia um ambiente em que o jogador penetra em um mundo alternativo, podendo desempenhar o papel de um personagem virtual seja ele de qualquer época ou local. $\mathrm{O}$ avanço da internet permitiu que os games, que possibilitam a opção em jogar com equipes numerosas, se tornassem populares em todo o mundo.

Caracteriza os tipos de jogos cujo contexto deve manter a atenção do usuário na ação do jogo, tendo como função principal a diversão e a imersão do jogador (ROLLINGS; ADAMS, 2006).

\section{Games para Portadores de Necessidades Especiais}

Apropriados da realidade virtual, como citamos no capítulo 4.0, o psiquiatra americano Bem Springer (2010), defende que os games podem tanto permitir que usuários de videogames escapem do mundo real, como podem ajudar os portadores de necessidades especiais a “experimentarem” o mundo real, navegando por lugares que realmente existem.

Durante a última década, pequenas empresas, pesquisadores e desenvolvedores de games independentes desenvolveram inúmeros games que buscam acomodar as 
habilidades de jogadores com deficiências mais severas, seja mental, visual, física ou auditiva.

Os games acessíveis oferecem múltiplas interfaces para suportar diferentes tipos de deficiências. As limitações singulares do grupo-alvo tornam esses projetos interessantes, instrutivos e desafiadores para especialistas e pesquisadores.

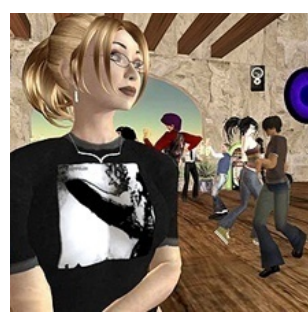

Figura 40

The Sims

\section{Games Sérios (Serious Game)}

De acordo com o capítulo 4.2, os games sérios são projetados e usados com a intenção e o propósito de abordar as questões mais prementes do nosso tempo e experimentar suas conseqüências como na vida real. Um exercício mental, jogado com o computador com um conjunto de regras específicas que usam o entretenimento como base para sua metodologia.

À medida que as plataformas tecnológicas e os games foram se aperfeiçoando, os "serious games" têm sido aproveitados em uma grande diversidade de áreas: defesa, serviços de saúde, educação, exploração científica, religião, políticas públicas, gestão de emergência, engenharia e planejamento urbano.

\section{Nível de Escolaridade (Item 2)}

Para que os professores, estudantes e pais possam selecionar games de acordo com o nível de escolaridade desejado é, necessário, fazer um balizamento dos games de acordo com a divisão por séries determinada pelo Conselho Nacional de Educação (CNE).

Em agosto de 2005, o CNE definiu normas nacionais para a ampliação do Ensino Fundamental nas escolas públicas brasileiras para nove anos, a Educação Infantil para criança de até 5 anos de idade. Portanto, o Ensino Fundamental I atende a alunos de 6 a 10 anos de idade, correspondendo ao ensino do $1^{\circ}$ ao $5^{\circ}$ ano e 
os quatro anos finais, o Fundamental II recebe alunos de 11 a 14 anos de idade, correspondendo ao ensino do $6^{\circ}$ ao $9^{\circ}$ ano.

O Ensino Médio, desenvolvido em três séries anuais, correspondendo ao ensino do $1^{\circ}$ ao $3^{\circ}$ ano, e tem em sua organização curricular a consolidação das competências e conteúdos necessários ao prosseguimento dos estudos em nível superior e/ou à inserção no mundo do trabalho.

\section{Área de Conhecimento (Item 3)}

Embora não haja no Brasil um currículo padronizado para todas as escolas do Ensino Fundamental e Médio, LDB n ${ }^{\circ} 9.394$ - Lei de Diretrizes e Bases da Educação Nacional (LDB) define como obrigatório em todo o país o ensino de Língua Portuguesa, Matemática, conhecimento do mundo físico e natural (Ciências, Física, Química, dependendo da fase escolar), conhecimento da realidade social e política, especialmente a do Brasil (História, Geografia etc.), Artes, Educação Física (obrigatória, exceto para alunos que trabalham seis ou mais horas diárias, prestam serviço militar, são maiores de 30 anos ou aqueles que têm filhos) e Música (que pode ser trabalhada dentro de Artes).

Em 1996, estabeleceu-se ainda a inclusão de Filosofia e Sociologia como disciplinas obrigatórias nos currículos do ensino médio.

Cada disciplina tem uma função como explica Gallo (2009):

(...) determinadas disciplinas são ferramentas instrumentais que auxiliam na compreensão dos conhecimentos, enquanto outras compõem a cosmologia contemporânea e outras ainda procuram explicitar a vivência e a apreensão histórica do espaço humano. (Sílvio Gallo,2009, Salto para o futuro, p.19)

Tendo por pressuposto o compromisso com a construção da cidadania, o Ministério da Educação, através do portal do MEC, indica necessariamente uma prática educacional voltada para a compreensão da realidade social e dos direitos e responsabilidades em relação à vida pessoal e coletiva e a afirmação do princípio da participação política.

Nessa perspectiva foram incorporados, pelos Parâmetros Curriculares Nacionais (PCN's) definidos pela Secretaria de Educação Básica do Ministério da Educação, seis temas que compreendem seis áreas e receberam o título geral de Temas Transversais: Ética (Respeito Mútuo, Justiça, Diálogo, Solidariedade), 
Orientação Sexual (Corpo: matriz da sexualidade, relações de gênero, prevenções das doenças sexualmente transmissíveis), Meio Ambiente (os ciclos da natureza, sociedade e meio ambiente, manejo e conservação ambiental) , Saúde (autocuidado, vida coletiva, orientação para o trânsito), Pluralidade Cultural (a vida das crianças no Brasil, constituição da pluralidade cultural no Brasil, o ser humano como agente social e produtor de cultura, cidadania) e Trabalho e Consumo (relações de trabalho, meios de comunicação de massas, publicidade e vendas, direitos humanos).

Em 2010, a Educação Financeira também foi incluída como tema transversal com base no Documento de Orientações para Educação Financeira nas Escolas (Plano Diretor da ENEF, 2010).

\section{Plataforma (Item 4)}

Pode ser definido como um termo geral da língua inglesa que se refere a equipamentos como ferramentas, utensílios e peças de máquinas. No âmbito eletrônico, o termo "hardware" é bastante utilizado, principalmente na área de computação, e se aplica ao tipo de plataforma, ou seja, à unidade central de processamento, à memória e aos dispositivos de entrada e saída (GALVIN, 2008).

Arcades, consoles e sensores de movimento são equipamentos limitados a games pagos pelo mercado da indústria de games. Na prática, o fato de haver uma grande disponibilidade de títulos de games gratuitos para desktop e dispositivos móveis, proporciona ao corpo docente e aos alunos uma possibilidade de experimentação sem envolver custos à escola e ao aprendizado, favorecendo, assim, o uso dessas plataformas para o ambiente de ensino.

\section{Arcades}

Assim como os fliperamas são produzidos em máquinas eletromecânicas operadas por moedas. Neste tipo de plataforma, as máquinas são compostas por uma tela presa a um gabinete, um painel de botões ou outros tipos de controle para se jogar o game (AGUIAR, 2010). O gabinete é decorado com o tema do game e o jogador costuma ficar em pé ou, no caso de simuladores, fica sentado em uma cadeira similar ao veículo que está jogando. O tempo de cada game é limitado ao número de rodadas que a moeda permite. 


\section{Consoles}

Desenvolvidos para ambientes domésticos, de acordo com o capítulo 2.2, os equipamentos são ligados a controladores manuais, que se conectam a um televisor ou monitor. Os consoles possuem um sistema próprio de programação de dados que pode ser ou não compatível com outros tipos de plataforma (XAVIER, 2007). Podem ser conectados à internet e usados para navegar na web. Alguns exemplos são Wii, Xbox ou PlayStation.

\section{Desktop}

Dispositivo eletrônico com capacidade para o processamento de dados e que pode ser de mesa ou manual (laptop). Os computadores, como já citado no capítulo 2.2, podem apresentar sistemas operacionais de fabricantes diversos como Microsoft, Apple ou Linux (XAVIER, 2007; MARX, 2007). São recomendados para games que exigem uma alta performance de hardware.

\section{Dispositivos móveis (Android/IOS/Windows)}

São dispositivos portáteis como celulares, tablets entre outros. Nesse tipo de equipamento, de acordo com o capítulo 2.2, a interação com o usuário é feita através de uma tela sensível ao toque e com um sistema operacional que permite que desenvolvedores criem games de extrema simplicidade e eficiência.

Os fabricantes de celulares (smartphones) e tablets desenvolveram distintos sistemas operacionais para dispositivos móveis com tela sensível ao toque. Os sistemas operacionais mais populares são o Android (Google), o IOS (Apple) e o Windows (Microsoft). Cada equipamento funciona com um único tipo de sistema operacional e os games precisam ser desenvolvidos em diferentes versões, de forma que, sejam compatíveis com cada sistema.

Nas redes de ensino, existe uma forte tendência ao uso de tablets com diversas aplicações de objetos digitais de aprendizado, como games educativos. 


\section{Sensores de movimento}

São equipamentos que precisam estar conectados aos consoles e, de acordo com o capítulo 2.2, eles se destacam pelo seu controle sem fios, dotado de um acelerômetro capaz de detectar movimentos em três dimensões. Os sensores de movimento não se tornaram um produto popular como os outros, devido ao seu custo adicional e por demandar de uma distância livre de pelo menos 1,8 metros. Entretanto, novas tecnologias estão permitindo aos jogadores interagir com os games sem a necessidade de ter em mãos o controle remoto, inovando no campo da jogabilidade (NOVAK, 2010).

\section{Base de Dados (Item 5)}

\section{Impresso}

Um game com a base de dados impressa é a denominação comum utilizada para os games que em geral estão prontos para serem jogados, não havendo nada em sua programação ou dados que possam ser alterados.

\section{Software de Autoria (Game Engine)}

São games editáveis, que permitem tanto aos professores, quanto aos alunos inserirem informações em seu jogo, viabilizando, assim, a autoria e a originalidade da história, bem como propiciando a aderência ao currículo escolar dos alunos.

Podem ser softwares educativos, simples lições digitais editáveis ou minigames engines.

As plataformas mais complexas de games educativos, têm versões de softwares de autoria que disponibilizam relatórios estatísticos da performance dos alunos para que os professores possam fazer um acompanhamento da aprendizagem dos mesmos, de forma individual ou coletiva.

Há produtos como Metaplace, Wonderland, Little Big Planet e Sims Carnival, sugeridos pelo designer instrucional João Mattar (2010), que suportam o design de games e devem ser explorados em função de seus potenciais para criar games voltados para o aprendizado. Nessa categoria encontram-se ainda engines de código aberto ou comerciais dos mais variado preços. 


\section{Direitos Autorais (Item 6)}

\section{Livre}

Game gratuito e disponível para ser baixado da internet (download) e carregado no computador ou on-line.

\section{Pago}

Há muitas empresas que produzem games de entretenimento ou educativo com direitos autorais restritos, e para acessá-los, é necessário fazer a sua compra em lojas físicas ou virtuais (com DVDs ou via streaming).

Empresas especializadas em educação produzem plataformas de games educativos e, geralmente, fornecem relatórios estatísticos do desempenho dos alunos-jogadores. Nesse caso, são celebrados contratos anuais entre a instituição educacional e a empresa.

\section{Acesso (Item 7)}

\section{On-line}

Os jogadores precisam de uma conexão à internet para acessar e jogar games online, através do computador, console, tablets ou celulares. Dependendo da complexidade e estilo do game, as informações podem ficar armazenadas em um servidor. No caso dos grandes games on-line que envolvem vários jogadores simultaneamente, são necessários vários servidores.

Existem diversos portais de entretenimento e educacionais, online, com mini games que dependem da conexão de banda larga. Assim como as plataformas (adaptativas) de games educativos, o aluno acumula pontos e tem seu desempenho registrado, podendo até ser acessada pelo seu professor para avaliar seu aprendizado através de estatísticas.

\section{Carregado (Off-line)}

Games carregados são aqueles que podem ser jogados independente do acesso à internet (off-line), baixados da internet e armazenados no computador ou, até mesmo, acessados através de dispositivos de memória, como DVDs.

Esse padrão tem mudado muito, de acordo com o avanço tecnológico, pois, dos anos 1970 pra cá, os games já foram vendidos em disquetes, CDs e 
DVDs. Com isso, não há a necessidade do jogador estar conectado à internet para jogar, bastando inserir o dispositivo de memória no computador.

Dessa mesma forma, tem funcionado o mercado de games em consoles, no qual as distribuidoras vendem os games através de cartuchos. Recentemente, a atualização dos games passou a ser feita via streaming, necessitando ser baixado através de conexões de banda larga.

É cada vez menos comum ter games disponíveis para se instalar no computador através de downloads. Devido à disseminação da banda larga pelo mundo, esse artifício permite que os games sejam jogados on-line, principalmente as versões para multijogadores, entretanto, ainda podemos encontrar versões de games para baixar e instalar no computador.

\section{Formato (Item 8)}

\section{Minigames e Games Complexos}

No processo da história dos vídeogames, os tradicionais jogos de cartas e tabuleiros sofreram adaptações para os dispositivos eletrônicos e se tornaram, o que hoje tratamos como mini games, que com raras exceções, são triviais. Segundo Prensky (2010), os demais games - certamente, bem mais que a metade, em termos de tempo de jogo - são de uma espécie totalmente nova: o game "complexo”.

Os games complexos de hoje, são algo além do que previamente conhecemos como os videogames dos anos 1970 e 1980, pois são uma nova espécie de jogo.

Prensky (2010) nos auxilia a compreender a sutileza com que os games têm se aperfeiçoando, através de um quadro comparativo a seguir:

\section{Minigames}

- Em geral, precisam de umas duas horas pra serem completados;

- Costumam oferecer um único desafio, com diversos níveis;

- São jogados por uma ou duas pessoas com raras exceções até quatro pessoas;

\section{Games Complexos}

- Podem exigir mais de cem horas pra serem completados;

- Exigem o domínio de habilidades e estratégias para avançar de nível;

- Podem demandar consultas externas ou a colaboração de outros jogadores de sua equipe; 
- Seus jogadores costumam jogar no papel deles mesmos;

- Regras simples e que, raramente, envolvem dilemas éticos e exigem decisões importantes;

- Incluem quase todos os jogos de cartas, como Paciência, jogos de perguntas, como Show do Milhão e jogos de tabuleiro, como Scrabble e, praticamente, todos os games educativos encontrados na internet.
- Seus jogadores, em geral, precisam assumir identidades alternativas;

- Sua regras precisam de várias horas de jogo para serem dominadas e são acrescidas de detalhes conforme $\mathbf{0}$ jogador avança de nível;

- São jogos multiplayers como o Call of Duty ou jogos que requisitam um equipamento mais sofisticado com melhor resolução gráfica e memória como o Sim City ou Civilization.

\section{Idioma (Item 9)}

Em consequência do pioneirismo e do grande mercado de games nos países de língua inglesa, a oferta de games de entretenimento, sérios e educacionais no idioma inglês é desproporcionalmente maior que a de games em português.

Contudo, há games educacionais que independem do idioma por ausência de palavras, alguns vêm legendados e eventualmente encontramos games ou portais que disponibilizam uma versão em português.

O Brasil se tornou, em 2013, segundo a SuperData Research, o maior mercado de venda de games da América Latina e o quinto maior do mundo, consequentemente, aqueceu a produção de games brasileiros, ofertando-se mais títulos em português. Nesse processo, estão surgindo pólos de produção de games de entretenimento e educacionais em várias cidades do Brasil.

\section{Jogador (Player Mode) (Item 10)}

Os vários modos de jogador, em um game, estão relacionados com o número de jogadores que jogam entre si ou quando jogam “contra” o computador. Esse número pode variar de um único jogador (monojogador/single player) a milhares de participantes (multijogadores massivos - MMOs).

Enquanto games para um jogador se tornaram muito comuns em arcades, e, posteriormente, em dispositivos móveis, os games para MMOs são jogados em desktops ou consoles. Com o game para multijogadores, também surgiu a possibilidade de comunicação entre os jogadores que estão on-line, 
pois eles podem usar um fone de ouvido com microfone para conversar com os membros de sua equipe. Essa tecnologia criou uma nova cultura de relação virtual entre os participantes.

\section{Um jogador (monojogador)}

Somente uma pessoa pode jogar um game monojogador, é o caso de um simples jogo de paciência.

A grande maioria dos jogos de consoles ou arcades modernos são projetados de modo que eles possam ser jogados por um só jogador. Embora muitos desses jogos tenham modos de jogo para dois ou mais jogadores (não necessariamente ao mesmo tempo), muito poucos realmente necessitam de mais de um jogador para o jogo ser realizado.

Games para um único jogador dependem de histórias mais interessantes para envolver o jogador em sua experiência lúdica. Os seres humanos, por sua vez, são imprevisíveis, por isso os jogadores humanos - aliados ou inimigos - são conduzidos em torno de uma história convincente, e não podem ser invocados a criar uma narrativa, mas conduzem o game em determinadas direções, enquanto que os jogos de modo multijogador, não tendem a se concentrar fortemente em uma narrativa linear.

\section{Homem-computador (monojogador)}

É uma variável de monojogador, na qual o jogador pode jogar contra o computador ou até mesmo contra jogadores adicionais, chamados de personagens de IA (inteligência artificial) ou personagens não jogadores (non-player characters-NPCs). As plataformas portáteis (como Nintendo DS) ou dispositivos móveis (como celulares) são ideais para games para um jogador ou contra o computador (NOVAK, 2010).

Nesse modo, o game possibilita que o jogador tenha um oponente ou um inimigo declarado. Dessa forma, o game proporciona uma caracterização profunda das personagens não-jogadoras, a fim de criar relações entre o jogador e todas as suas personagens, e também, desenvolver antipatia profunda pelo antagonista do game. Isso ocorre geralmente em role-playing games (RPGs), como a série Final Fantasy, que é essencialmente orientado para o personagem. 


\section{Homem-homem (multijogador)}

Enquanto um jogo monojogador desenvolve sua jogabilidade com personagens artificiais, esse modo com multiplayer (múltiplos jogadores ou multijogador) depende de interação humano-humano para sua ação, disputa ou conflito, e muitas vezes por seu senso de camaradagem. Alguns dos primeiros videogames foram desenvolvidos para dois jogadores, de acordo com KOL, incluindo os primeiros games de esporte (como edição de 1958 da Tennis For Two e 1972 de Pong), jogos de tiro (como o Spacewar ! de 1962) e jogos de vídeo de corrida (como Astro Race de 1973). Os primeiros exemplos de jogos em tempo real para múltiplos jogadores foram desenvolvidos no sistema PLATO, em 1973.

Os games para multijogadores em consoles, arcades e computadores pessoais, permitem em jogar com até quatro controle-remotos conectados ao equipamento. Essas versões de game, usam tela dividida, de modo que cada jogador tem uma vista individual de sua ação (como em games de tiro em primeira-pessoa e de corrida).

\section{MMOGs}

(Massive Multiplayer On-line Games/Games para Multijogadores Massivos On-line)

É um modo de game que demanda conexão de banda larga para a internet, estar disponível 24 horas e a partida não termina quando um jogador se desconecta do game. A produção de seu conteúdo é um processo contínuo. Uma das maiores dificuldades dos desenvolvedores é equilibrar a interação social e a imersão sobre os objetivos individuais do jogador.

MMOGs permitem que os jogadores cooperem e compitam uns com os outros em grandes escalas, proporcionando uma interação significativa com pessoas ao redor do mundo. O World of Warcraft (WoW) é o mais popular MMOG que, por sua vez, em 2010, ultrapassou a marca de 10 milhões de jogadores registrados em todo o mundo (Fonte: Statista - Portal de Estatísticas).

Estes games podem ser encontrados para a maioria das plataformas com capacidade de rede, incluindo o computador pessoal , console de videogame, smartphones e outros dispositivos móveis . 


\section{Turno (Item 11)}

É como se dá a rodada em relação ao tempo, assim, define-se o ritmo do game. Esse ritmo indica se o game é jogado por reflexo ou reflexão. Nesse caso, o tipo de turno determina se o jogador terá um tempo ilimitado para resolver o desafio, qualquer que seja o estilo, ou se ele terá de reagir rapidamente para atingir o seu objetivo (NOVAK, 2010).

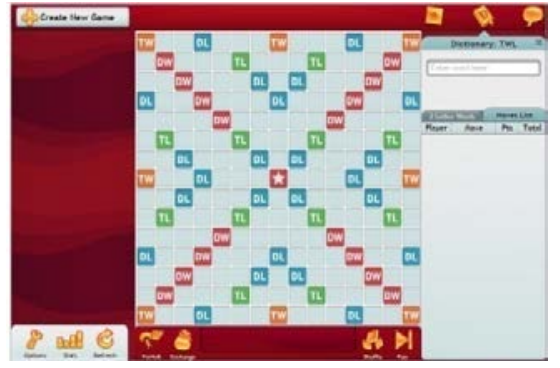

Figura 41. Scrabble

\section{Baseado em Turnos}

Estrutura tradicional dos jogos de tabuleiro e cartas, cada jogador tem a sua vez e dispõe de seu turno para mover uma peça ou jogar uma carta, prevalecendo o raciocínio. Geralmente o tempo para cada turno é ilimitado, com exceções de alguns jogos, cujas regras estabelecem um limite de tempo para fazer com que o jogador seja mais ágil em suas decisões (NOVAK, 2010).

Também há games complexos de simulação de processos ou batalhas que são estruturados em turnos, prevalecendo a rodada independente do tempo.

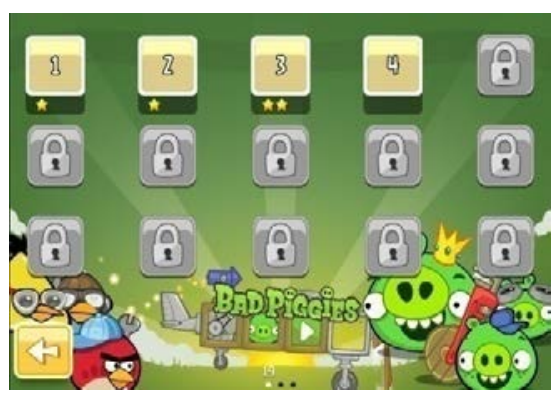

Figura 42. Angry Birds

\section{Desbloqueio de Níveis}

Nesse modo de turno, muito aplicado em minigames com partidas rápidas, a dinâmica do game proporciona que o jogador passe para um próximo nível depois que completar o desafio. Cada nível apresenta alguma característica diferente, como uma maior dificuldade para a realização do desafio. Esse modo propicia envolvimento e um aprendizado adaptativo, já que cada jogador passa de nível, de acordo com a sua capacidade individual e seu tempo. 


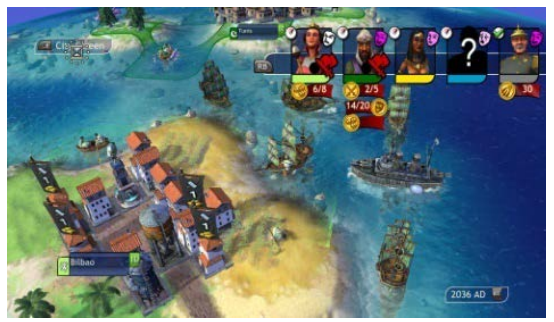

Figura 43. Civilization VI

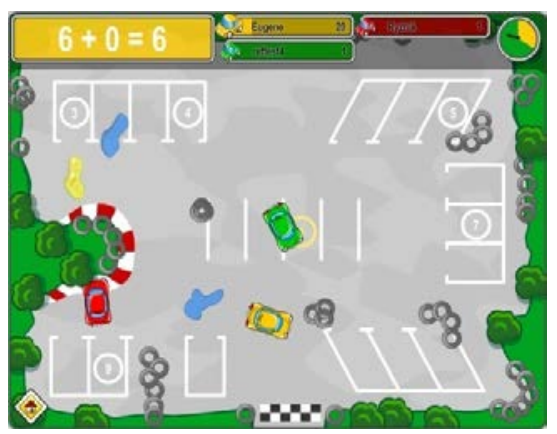

Figura 44.

Math Racing Equations

\section{Em tempo real}

Ao contrário de um game baseado em turnos, não há intervalo de tempo, nem sequer, há turnos. A jogabilidade desse tipo de game demanda de agilidade e rapidez ao contrário dos games em que prevalece o puro raciocínio. Os games em tempo real dependem de uma satisfatória conexão à internet, o que pode limitar certas regiões que não dispõem de banda larga. Segundo NOVAK (2010), mesmo assim, os games em tempo real se tornaram extremamente populares, estimulados pela possibilidade de comunicação instantânea com outros jogadores que estejam jogando a mesma partida.

\section{Partida única}

Muito característico dos minigames, as partidas únicas não costumam ser longas, mas diferentemente do modo com desbloqueio de níveis, tem uma única estrutura e balanceamento. Caso o jogador não consiga completar o desafio, ele terá a oportunidade de jogar o game até que o aprenda e finalize.

Vários games complexos, incluindo RPGs, tem a estrutura de uma única partida, e são desenvolvidos em torno de uma história com início, meio e fim.

\section{Gênero (Item 12)}

Para melhor compreender o fundamento de cada tipo de game, podemos classificá-los em nove gêneros, que se distinguem um do outro, por sua metodologia. São eles: ação, artístico, aventura, casuais, desafios, estratégia, 
exercícios, RPGs e simuladores, cada um com suas características próprias. Contudo, há games que se beneficiam de mais de um tipo de gênero.

Desse modo, apresenta-se a classificação por gênero a partir de categorias mais comuns na área de games:

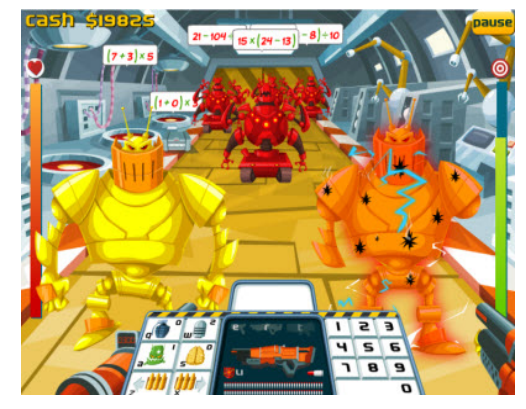

Figura 45.

Bidmas Blaster

(Mangahigh)

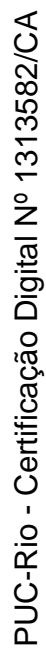

\section{Ação}

VAN ECK (2006) define games de ação como o tipo de jogos em que a jogabilidade, consiste, principalmente, em atividades que exigem tempo de reação rápida, coordenação e reflexos, e, em muitos casos, também uma familiaridade com ataques padrão.

Em geral, esta categoria permite uma divisão em subclasses como jogos de luta, jogos de tiro (shooter), plataforma e jogos de ação em terceira pessoa. Os HUDs são muito utilizados em forma de painéis nos cantos da tela para manter o jogador informado de sua progressão ao mesmo tempo em que joga (NOVAK, 2010).

\section{Artístico}

São games e atividades voltadas para as artes, sejam artes plásticas, dança ou música. Na última década, surgiu uma grande oferta de aplicativos para dispositivos móveis com esse gênero de game, principalmente, os tablets que favorecem por seu formato e a facilidade de seu manuseio, tanto para o público adulto (amadores e profissionais) como o infantil. 


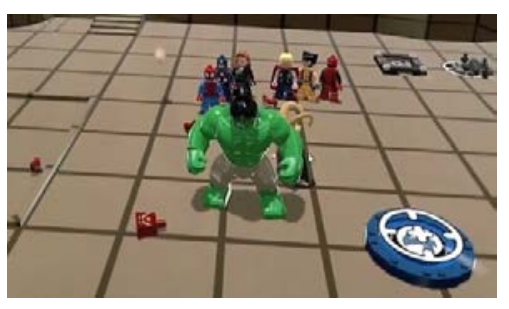

Figura 47. Lego Super Heroes

\section{Aventura}

Os games de aventura são definidos como uma ampla categoria de jogos de fantasia na qual o jogador tem que ultrapassar uma série de obstáculos (geralmente relacionados a uma narrativa) para atingir um destino, alcançar objetos ou conquistar cidades (CRAWFORD, 1998). Games de aventura são mais suscetíveis de compreender oportunidades de reflexão e escolhas por requerem planejamento de longo prazo e estratégia. Suas navegações, geralmente, são realizadas por interfaces de aponta-e-clica ou de controle direto.

Contudo, Van Eck (2006) avalia que os games de aventura e RPGs (role-playing games) são, por vezes classificados como o mesmo tipo de jogabilidade. Sendo que os games de RPGs são mais propensos a desenvolverem um apego emocional ou psicológico ao personagem em consequência da personalização e conquistas de seu protagonista. Além de seu constante aumento de popularidade de versões com multiplayer roleplaying games on-line (MMORPGs ) .

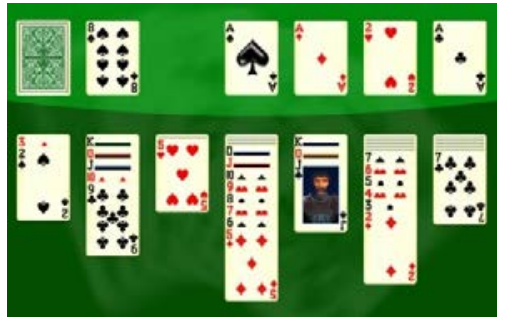

Figura 48. Solitare

\section{Convencional}

São os jogos adaptados para o ambiente digital que têm sido jogados há milhares de anos e sua implementação para o ambiente digital é muito bem sucedida. São fáceis para se programar e, por essa razão pode-se encontrar inúmeras versões de paciência, pôquer, mahjohg entre outros (CRAWFORD, 1997).

Posteriormente, foram surgindo inúmeras versões do mesmo jogo e atualmente pode-se 


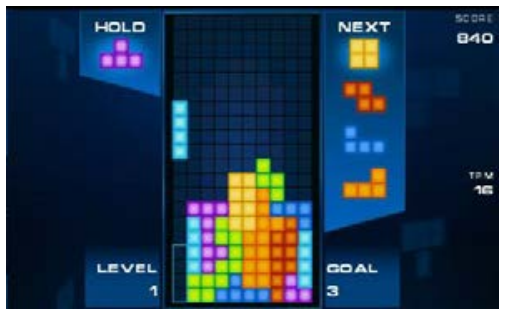

Figura 49. Tetris (conceito original e design de Alexey Pajitnov, 1987)

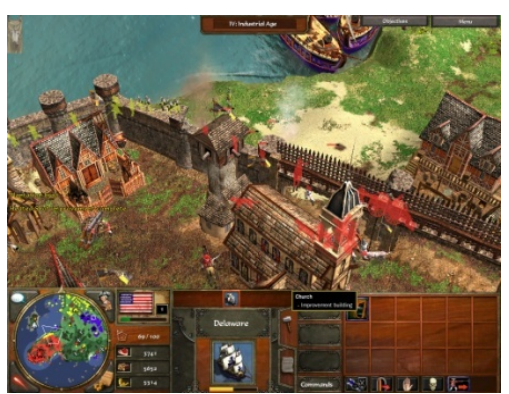

Figura 50. Age of Empires 3 (Game em tempo real) encontrar elementos como cartas ou tabuleiros incorporados em games modernos.

\section{Desafios (Puzzles)}

Correspondem aos jogos de encaixe, quebra-cabeças, trívia etc. Em situações diversas podem exigir respostas rápidas, criativas e pontuais, desafiando o usuário a traçar estratégias cognitivas para solucionar enigmas, blefar, montar, encaixar etc. (AGUIAR, 2010).

Tirando-se o enredo que é puro pretexto e com infinitas variáveis, Prensky (2010) é sintético ao dizer que os quebracabeças são simplesmente problemas que precisam ser resolvidos.

\section{Estratégia}

A maioria desses games envolvem temas de conquistas, exploração e comércio. A estratégia básica do jogador nesses games é a gestão de recursos, como alimentos, armas, construções, gastos com recursos, alimentos, tropas militares (NOVAK, 2010). Esse gênero permite testar as habilidades do jogador para administrar destrezas e capacidades relacionadas a recursos humanos e recursos materiais. Utilizase de respostas cognitivas para provocar as ações dos jogadores, dividindo-se em duas sub-classes (AGUIAR, 2010) apresentadas a seguir: games de estratégia baseados em turno; games de estratégia em tempo real. 


\section{Games de estratégia baseados em turnos} (TBS - turn-based strategy): correspondem aos jogos de guerra clássicos (wargames) que simulam situações de conflito militar real ou fictício, e permitem ao jogador traçar estratégias de combate. Até o final da década de 1990, quase todos os games de estratégia tinham esse perfil, permitindo que o jogador tivesse todo o tempo a seu dispor para a gestão de recursos e a movimentação de seus elementos.

\section{Games de estratégia em tempo real (RTS -} real-time strategy): os jogadores devem gerenciar em tempo real recursos ou tropas. $\mathrm{O}$ jogador de RTS é constantemente pressionado pelos acontecimentos e não dispõem de tempo livre para avaliar com detalhes suas decisões de jogada.

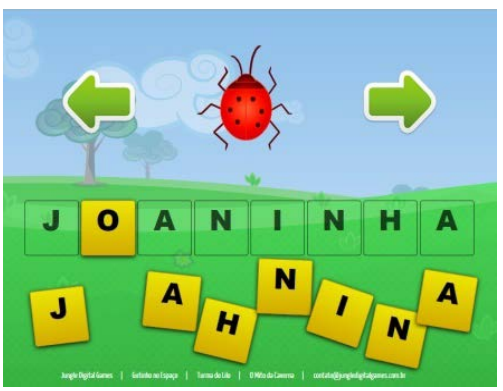

\section{Exercício}

São objetos digitais de aprendizado desenvolvidos com a estrutura e o dinamismo similares aos games de entretenimento. Suas dinâmicas apresentam quatro perfis: atividades educacionais, exercícios de múltipla-escolha, exercícios dinâmicos e simulações

Figura 51. Turma do Lilo de laboratório que, sem exceção, apresentam total aderência ao currículo escolar. 


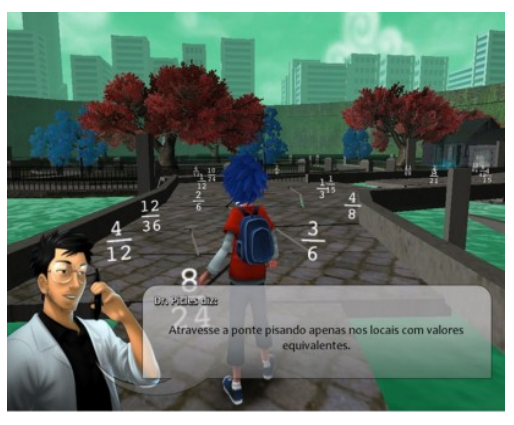

Figura 52. Mito da Caverna

\section{RPG}

Como games de aventura, os RPGs (roleplaying games), games de representação de personagens, se caracterizam pela importância da narrativa, no entanto, eles são compostos por personagens que se aprimoram ao longo do game. Os temas de RPGs geralmente são variações do tema geral de "salvar o mundo", como encontrar o responsável por um assassinato, resgatar alguém, destruir um objeto perigoso ou eliminar monstros. A socialização, a imaginação e a cooperação continuam a ser os pilares principais desse tipo de game.

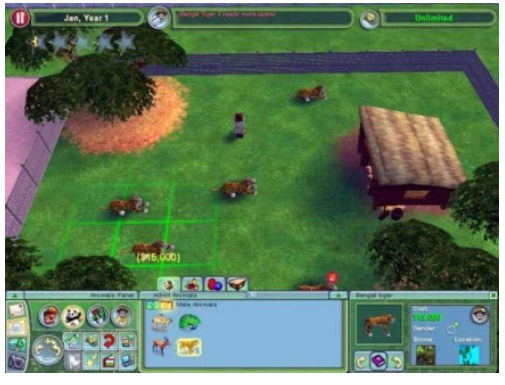

Figura 53. Zoo Tycoon

\section{Simuladores}

Podemos identificar quatro distintas dinâmicas nos games de simulação: casual (cotidiano), esportivo (em geral), processo (construção) e veículos (terrestres, aquáticos, aéreos e espaciais). Contudo, o aspecto mais difícil do design de interface para os games de simulação, segundo Novak (2010), é a necessidade de eficiência, precisão ou rapidez em sua jogabilidade.

Curiosamente, com o desenvolvimento dos dispositivos móveis, houve uma profusão de títulos de simulação casual para o público infanto-juvenil. 


\section{Dinâmica (Item 13)}

Essa categoria nos apresenta a diversidade de dinâmicas que podemos encontrar nos games de hoje. As dinâmicas estão classificadas em relação a sua jogabilidade, estrutura de interface e seus elementos. Identificamos 32 distintas dinâmicas, a partir dos oito gêneros de games, sendo que há games compostos por mais de uma dinâmica.

Enquanto um game de tabuleiro como o Monopoly (versão original do Banco Imobiliário), por mais complexo que possa ser desenvolvido, sua dinâmica e regras já são conhecidas devido a sua versão original em tabuleiro físico, um game como Minecraft, além de ser um simulador de processos que demanda de objetivos específicos, o personagem precisa combater em primeira pessoa (ex.: Call of Duty), assim como se deslocar, correr e saltar obstáculos como nos sofisticados jogos de plataforma em 3D (ex.: Assassins Creed).

A seguir, apresentamos as mais variadas dinâmicas de games, que podem ser aplicados, de uma forma ou de outra, como objetos digitais de aprendizado e dar apoio ao currículo escolar, incluindo determinados games de entretenimento ou sérios que cumprem esse papel. A seleção de dinâmicas aplicadas a games educativos envolve muitas variáveis e conforme o avanço das TICs mais novidades continuarão a surgir no mercado educacional e comercial de games.

[1] Aponta+Clica (point and click - p\&c)

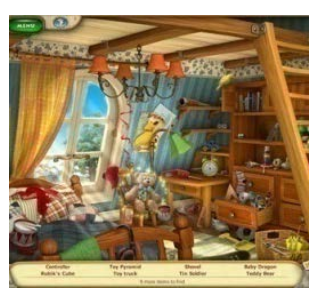

Simples de jogar, costumam ser games de localizar objetos ou "sete erros".

\section{Ex.: Farm Scapes}

[3] Associação Dinâmica

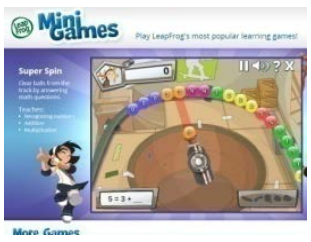

Games populares de passatempos dinâmicos, que envolvem a associação de objetos por cores ou formas.

Ex.: Super Spin (Portal Leap Frog)
[2] Artes

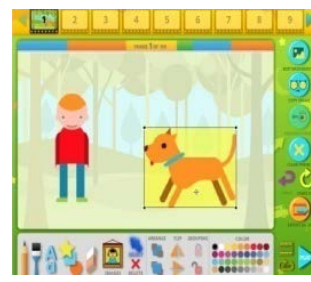

Aplicativos para colorir, recortar, fazer efeitos visuais, animação etc.

Ex.: Animate (Portal ABCya)

[4] Batedor (paddle)

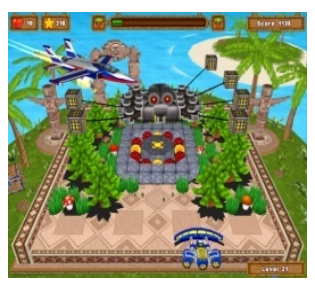

Dos primórdios da história dos games, o tradicional batedor com bolinha se modernizou.

Ex.:Breakout 
[5] Caça-Palavras

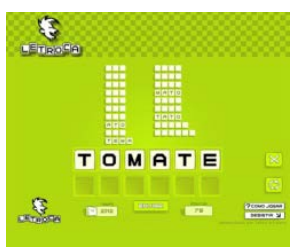

O tradicional passatempo, e similares como a "Forca", ganharam suas versões digitais e novos desdobramentos propiciados pela tecnologia.

Ex.: Letroca

[7] Casuais (infantis)

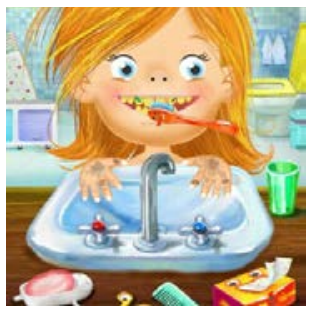

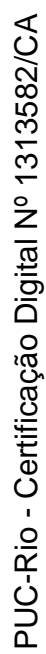

[9] Corrida

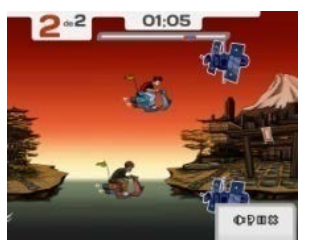

Das mais simples às mais sofisticadas, as corridas simulam o deslocamento dos jogadores. Pode ser jogado contra o computador ou contra outros jogadores.

\section{Ex.: Racing (Oje)}

[11] Enigma

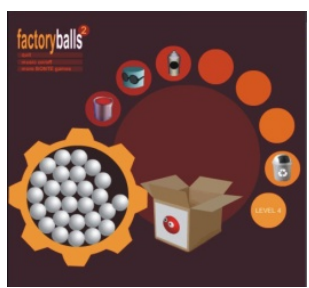

Minigames que nos desafiam para encontrarmos a solução oferecem os mais diversos temas e dinâmicas. Tem para todas as idades.

Ex.: Factory Balls (Kongregate)

\section{[6] Cartas}

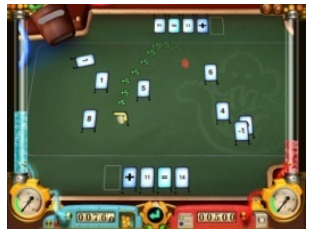

Além dos tradicionais games de paciência, bridge e poker, tem surgido as mais distintas versões de games baseados em suas dinâmicas, incluindo versões para multijogadores.

Ex.: Monkey Tales

[8] Clica e Arrasta (click and drop - c\&d)

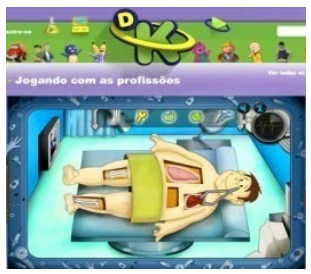

Dois comandos básicos, costumam ter interface intuitiva e envolve grande parte dos minigames.

Ex.: Jogando com as Profissões (Discovery Kids)

[10] Dança

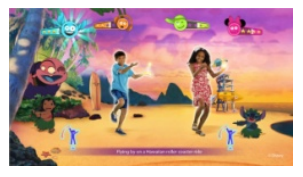

Popularizou-se com os arcades das lojas de jogos eletrônicos até chegarem nas academias de ginástica e residências.

Ex.: Just Dance

[12] Esporte

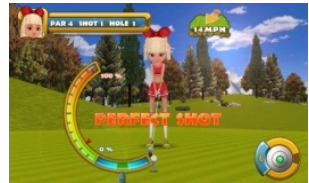

É possível jogar, independente da capacidade e habilidade física real do usuário. Em muitos games do gênero é possível utilizar os parâmetros da dinâmica, visando o aprendizado.

Ex.: Golf Championship 
[13] Estratégia (baseada em tempo real/RTS)

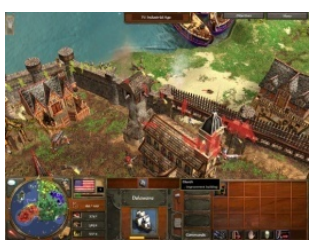

Voltado pra construção de cidades e batalhas, se joga conectado a internet, ocorre em tempo real.

\section{Ex.: Age of Empires}

[15] Luta

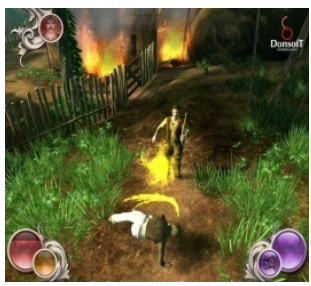

Dos arcades para outros dispositivos, os games de luta se sofisticaram em sua precisão e qualidade gráfica. Ex.: Capoeira Legends

\section{[17] Múltipla-Escolha (Dinâmica)}

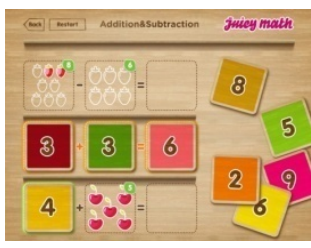

Os exercícios de múltipla-escolha evoluíram e tem versões ilustradas e animadas.

Ex.: Juicy Math

[19] Musical

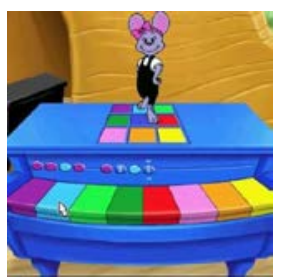

A música digital teve muitos avanços e com eles surgiram games.

Ex.: Coelho Sabido

[21] Preenchimento

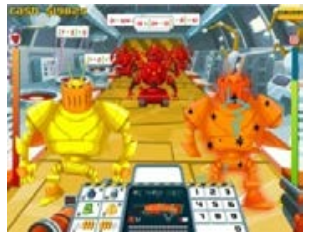

Minigames com exercícios dinâmicos, apresentam espaço para o preenchimento de respostas.

Ex.: Bidmas Blaster (Mangahigh)
[14] Estratégia (baseada em turno/TBS)

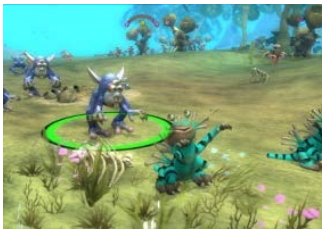

Similares aos

games de estratégia de RTS, os games

baseados em turno são jogados offline.

Ex.: Spore

[16] Memória

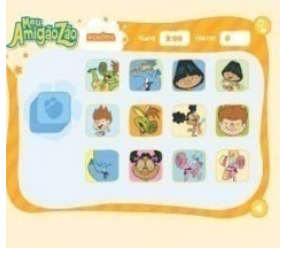

Tradicional jogo de encontrar o par em meio as peças viradas, tem muitas versões digitais devido a sua simplicidade.

Ex.: Memória (Meu Amigãozão)

[18] Múltipla-Escolha (Estática)

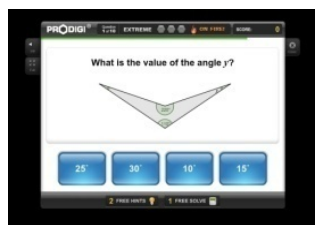

Adaptada do papel para o digital, esses exercícios podem oferecer estatísticas dos resultados do jogador.

\section{Ex.: Prodige (Mangahigh)}

\section{[20] Plataforma}

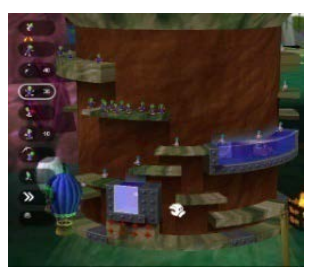

Modelo tradicional de game, que se perpetuou com suas missões e seu "sobe e desce" sobre suas plataformas.

\section{Ex.: Lemmings}

[22] Quebra-cabeça

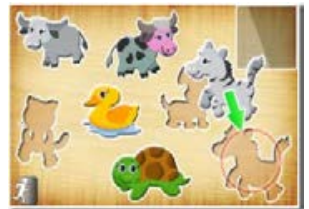

Tradicional jogo de organizar peças, ganhou inúmeras versões digitais.

\section{Ex.: Tozzle}

(Log Lin) 
[23] RPG

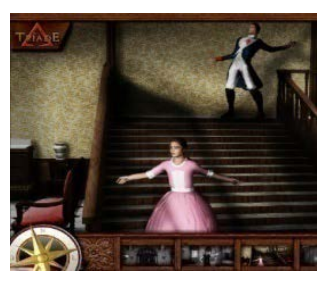

São histórias com missões específicas com representação de personagens reais, fictícios ou autorais.

Ex.: Tríade

[25] Simulação de Processos

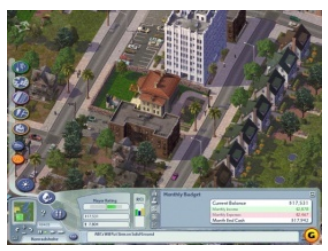

Propicia uma

experiência ao jogador de construir e administrar cidades, parques, zoológicos etc.

\section{Ex.: The Sim City}

[27] Tabuleiro (Diversos)

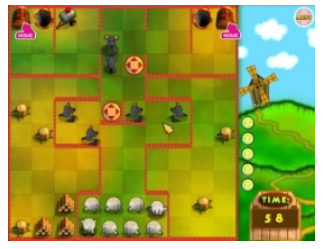

Apresentam um tema e um personagem, que por um caminho desvia de obstáculos e coleta itens.

Ex.: Mergulho Marinho (Ludo Educativo)

\section{[29] Tiro}

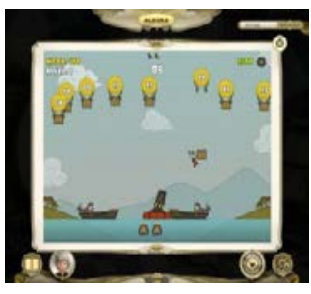

Diversos tipos de minigames usam desse comando de tiro. De balas de canhão a pássaros.

Ex.: Salva-carga (Ludz)

[31] Trilha

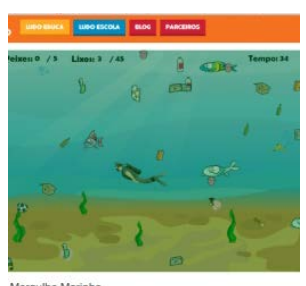

Apresentam um tema e um personagem, que por um caminho desvia de obstáculos e coleta itens.

Ex.: Mergulho Marinho (Ludo Educativo)

[24] Simulação de Laboratório

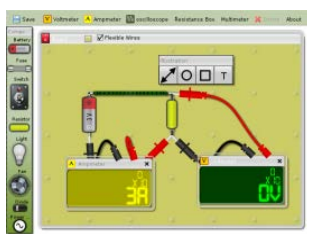

São simuladores de experimentos físicoquímicos e biológicos que em sua versão digital não oferece perigo algum ao estudante.

Ex.: Eletricity (Phet Interactive)

[26] Simulação de Veículos

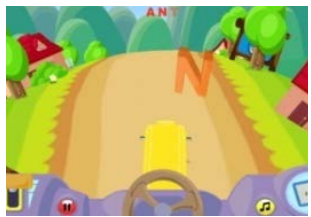

Terrestres, aéreos, aquáticos ou espaciais, seus games se apresentam nos mais variados níveis de complexidade.

Ex.: The Alphabet Car

[28] Tabuleiro (Jogos Tradicionais)

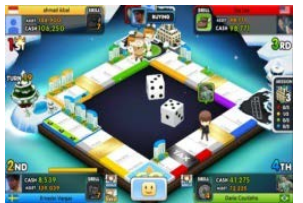

Adaptação dos tradicionais jogos de tabuleiro para os games.

Ex.: Star City Tycoon

[30] Traçando Letras

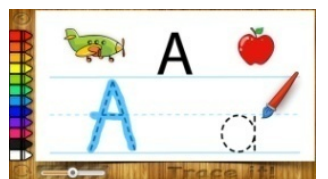

Oferecem dinâmicas variadas para exercitar o traçado de letras.

Ex.: Mzstatic

[32] Trívia

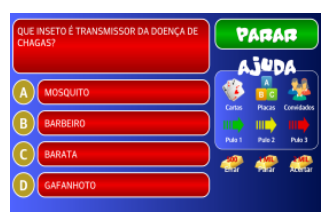

Minigames de perguntas e respostas. Se popularizou ao ser jogado em celulares. Ex.: Show do Milhão

Quadro 5. Dinâmica: 32 variáveis 


\section{1.}

\section{Apoio ao docente: selecionando games para seus alunos}

Nas últimas décadas, muitas instituições públicas e empresas privadas, pelo mundo, vêm desenvolvendo portais de objetos digitais educacionais para estudantes e professores. No Brasil, em 2014, foi lançado um portal com amplo conteúdo digital educacional, chamado Escola Digital, uma iniciativa do Instituto Inspirare de São Paulo.

Esses portais contêm uma grande variedade de games, exercícios e atividades e, alguns deles, ainda disponibilizam artigos e material de apoio para professores e pais. Dessa forma, eles são de grande ajuda, sendo que uma minoria dos portais também oferece acompanhamento estatístico do andamento de seus alunos conforme vão jogando seus games e fazendo suas atividades.

O Brasil, por sua vez, carece não só de objetos digitais educacionais em português e que sejam tematizados com os padrões culturais das regiões brasileiras, mas de portais que organizam dezenas ou centenas de objetos digitais de aprendizado.

Para auxiliar o usuário (estudante, professor ou pais) a identificar o tipo de objeto digital que esteja procurando, os portais oferecem filtros específicos que possibilitam essa seleção. Ao oferecer uma maior quantidade de filtros não significa, necessariamente, mais eficiência na busca ou na boa qualidade do material sugerido.

A seguir apresentamos alguns exemplos:

\section{ABC MOUSE (EUA)}

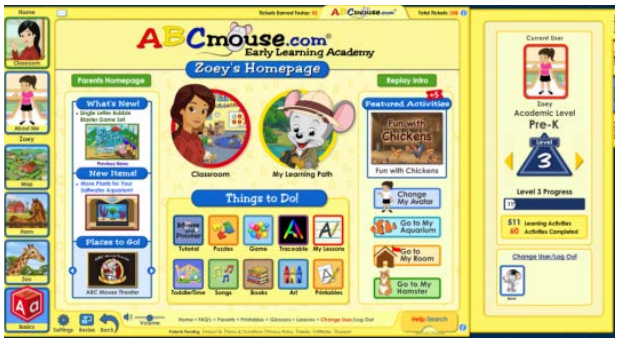

Figura 54
$<$ http://abcmouse.com>

Portal americano de objetos educacionais digitais infantis com exercícios de leitura e matemática, games e músicas

$\underline{\text { Série }}$

Infantil (3 níveis)

\section{$\underline{\text { Temas }}$}

Leitura, Matemática, Nosso mundo, Arte, Música e Diversos 


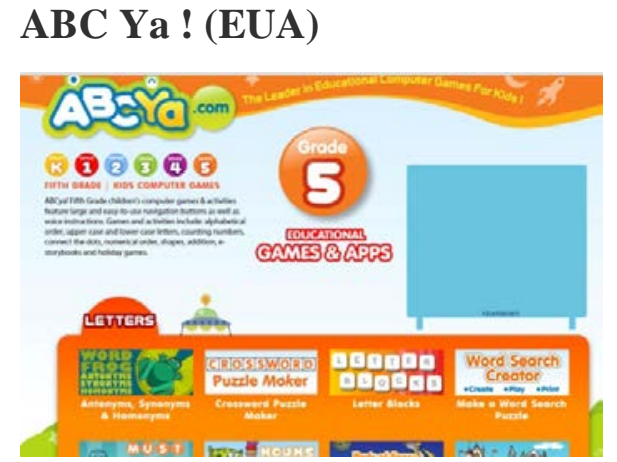

Figura 55

$<$ http://www.abcya.com/>

Portal americano de games e atividades infantis

Série

Infantil, 1 a 5

Temas

Letras, Números, diversos

Produção de animação quadro a quadro para crianças:

http://www.abcya.com/animate

<http://www.bbc.co.uk/bitesize/ks1/>

Portal inglês de objetos educacionais digitais infantis com exercícios de leitura e matemática além de games

Série

Infantil, 1 a 3

Temas

Matemática, Leitura e Ciências

\section{Figura 56}

\section{BRAIN POP (EUA)}

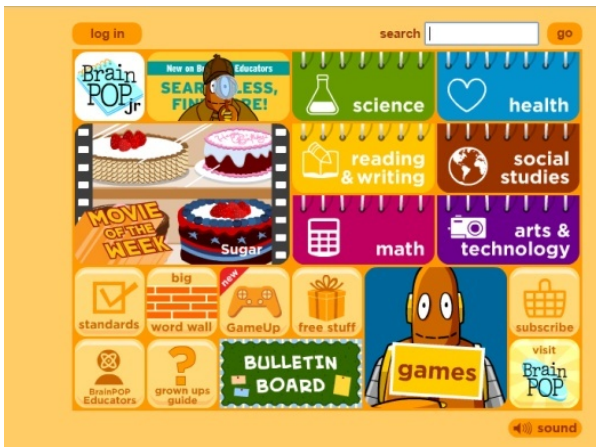

$<$ http://www.brainpopjr.com>

Portal americano educativo com exercícios de leitura e matemática, games, artigos educacionais, vídeos e atividades educacionais variadas

Série

Infantil, 1 a 3

$\underline{\text { Temas }}$

Matemática, Leitura e Escrita, Ciências, Saúde, Estudos Sociais, Artes e Tecnologia

Figura 57

ESCOLA DIGITAL (Brasil)

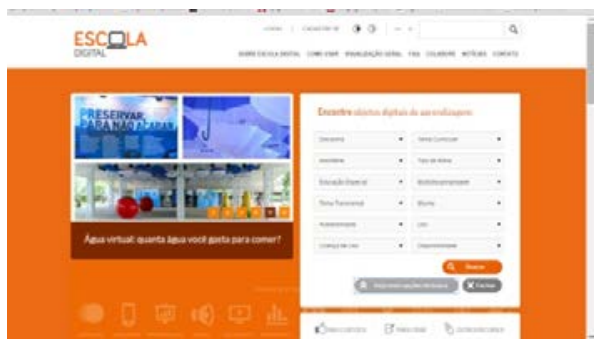

Figura 58
$<$ http://escoladigital.org.br/>

Portal de objetos educacionais digitais, como: animações, aplicativos móveis, apresentação multimídia, áudio, aula digital, infográfico, game, livro digital, mapa, simulador, software e vídeo.

Série - 15 perfis (Educação de Jovens e Adultos, Educação Especial, Educação Infantil, $1^{\circ}$ ano EF, $2^{\circ}$ ano EF, $3^{\circ}$ ano EF, $4^{\circ}$ ano EF, $5^{\circ}$ ano EF, $6^{\circ}$ ano $\mathrm{EF}, 7^{\circ}$ ano EF, $8^{\circ}$ ano EF, $9^{\circ}$ ano $\mathrm{EF}, 1^{\mathrm{a}}$ série $\mathrm{EM}, 2^{\mathrm{a}}$ série $\mathrm{EM}, 3^{\mathrm{a}}$ série $\left.\mathrm{EM}\right)$ 
Tema Curricular - 95 temas

Disciplina - 14 disciplinas

Tipo de Mídia - 30 tipos

Educação Especial - 2 perfis (deficiência auditiva e visual)

Multidisciplinaridade -15 disciplinas

Tema Transversal -7 temas

Idioma - 5 idiomas

Acessibilidade - 4 perfis (superdotação, deficiência auditiva, intelectual e visual)

Uso- 2 tipos (gratuito ou pago)

Licença de Uso -6 tipos

Disponibilidade -2 tipos (offline ou online)

ESCOLA GAMES (Brasil)

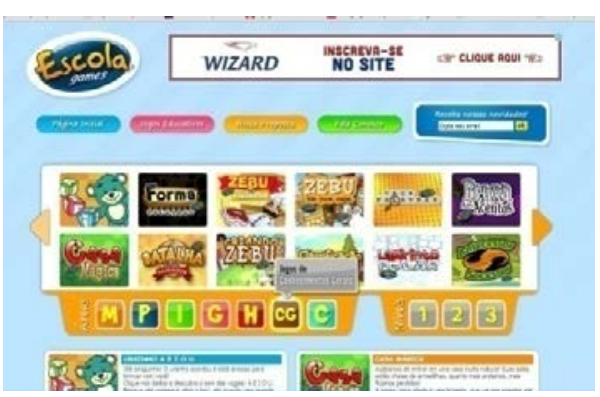

Figura 59

\section{FUNBRAIN (EUA)}

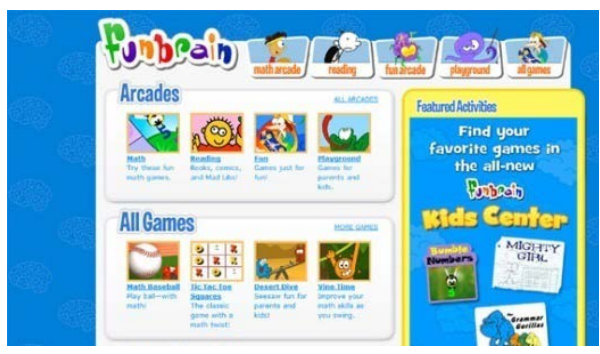

Figura 60

LEARN ALBERTA (Canadá)

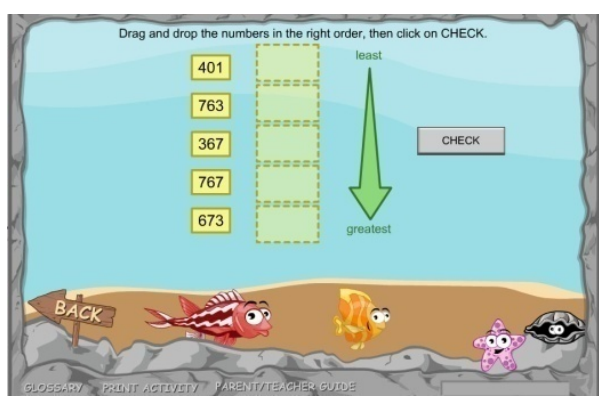

Figura 61 <http://www.escolagames.com.br/jogos.asp>

Portal brasileiro de minigames infantis

Série

Nível 1, 2 e 3

$\underline{\text { Temas }}$

Matemática, Português, Inglês, Geografia, História, Conhecimentos Gerais e Ciências

$<$ http://www.funbrain.com/>

Portal americano de objetos educacionais digitais infantis com exercícios de leitura e matemática, games de entretenimento e educativos.

Série

Infantil, 1 a 8

$\underline{\text { Temas }}$

Matemática, Leitura e Diversos

$<$ http://www.learnalberta.ca>

Portal canadense educacional com games, exercícios, atividades e artigos para os estudantes, professores e pais

Série - Educação Infantil e séries de 1 a 12

Disciplinas - 18 temas e disciplinas

Formato - 14 tipos (Artigos, Cursos, Games, Aulas Digitais, Mapas, Demonstrações, Experimentos, Simulações, Infográficos, 
Plano de Aulas, Material de Consulta, Material para Estudantes Especiais, Aplicativos, Apoio para professores)

$\underline{\text { Idiomas }}-7$ idiomas

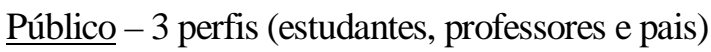

PHET (EUA)

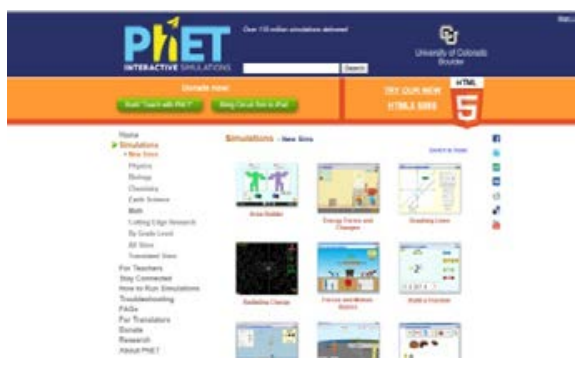

Figura 62

SMART KIDS (Brasil)

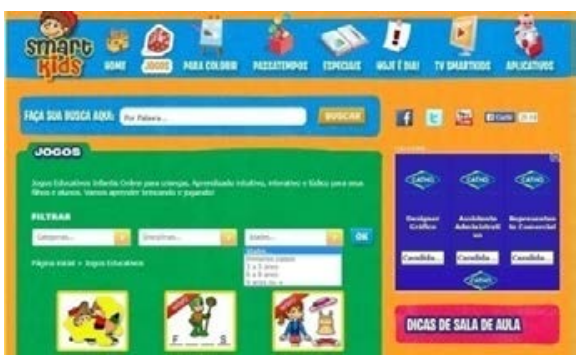

Figura 63
$<$ http://phet.colorado.edu/en/simulations/category/new>

Portal americano de simulação de laboratório e exercícios digitais

com versão em português

Série

Fundamental I, Fundamental II, Ensino Médio e Universitário

$\underline{\text { Temas }}$

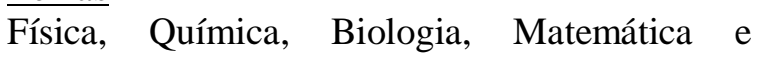
Ciências

$<$ http://www.smartkids.com.br>

Portal brasileiro de objetos educacionais digitais infantis com games, atividade de artes, artigos, vídeos e aplicativos

Série

Educação Infantil, 3 a 5 anos, 6 a 8 anos, 9 ou +

$\underline{\text { Temas }}$

Artes, Ciências, Datas Comemorativas, Educação Física, Geografia, História, Língua Portuguesa e Matemática

Esta pesquisa tem o intuito de contribuir para um novo paradigma de aprendizado no Brasil, e que vem ao encontro da demanda dessa geração de estudantes que nasceram e crescem nessa era da tecnologia e da informação, da globalização e a democratização virtual de suas fronteiras.

Para cumprir esse papel, nesse documento foi desenvolvida e apresentada uma taxonomia para os games educativos e identificados e listados games e portais nacionais e internacionais disponíveis na rede.

Essas informações podem servir como base de construção para portais de games educativos, como uma ferramenta para incentivar os estudantes com o seu aprendizado, seja no ambiente doméstico ou escolar, a fim de envolvê-lo em seu processo de formação educacional e preparo para a vida profissional. 


\section{6.}

\section{Considerações finais}

Ao longo de todo o desenvolvimento dessa pesquisa me envolvi em um constante diálogo interdisciplinar ente Design, Educação e Tecnologia. Para cada estudo, uma dessas três áreas de conhecimento estava à frente, mas sem que eu pudesse deixar de estar atento sobre o comportamento das outras duas áreas em torno do específico estudo.

Em vários momentos da pesquisa, confrontei-me com a resistência de alguns profissionais ou estudantes da área de educação em relação ao uso de tecnologia na educação e, mais ainda, com a inclusão de games no processo de aprendizado de um aluno. Entretanto, ao expor os argumentos levantados ao longo dessa pesquisa, pude perceber uma flexibilização na retórica desses indivíduos. Para tal situação, Valente (2010) ressalta que o próprio Platão mostrou-se receoso diante da escrita como uma tecnologia que viria a diminuir a capacidade de memória presente na oralidade. Apesar de muitos ficarem temerosos, a sociedade se apropriou dessa tecnologia, fazendo com que a escrita desse início a uma nova realidade.

Para falar de games educativos, foi preciso para essa pesquisa incluir e analisar toda sorte de games para que pudéssemos compreender o que esses jogos eletrônicos têm que o fazem tão envolventes e atrativos para milhões de crianças, jovens e também adultos em todo o mundo, a fim de transportar suas estratégias aos games que venham servir como objetos digitais de aprendizado. Esse fenômeno foi observado pelo matemático americano Seymour Papert (1994) desde a década de 1970 nos EUA. E a partir da década seguinte, muitos educadores e estudiosos passam a defender o aproveitamento desse recurso enquanto ferramenta de ensino, constituindo uma verdadeira revolução do processo de aprendizagem e uma chance para transformar a escola.

Entretanto, vale a pena ressaltar que a presente pesquisa teve o foco voltado para a realidade brasileira, tanto que James Paul Gee (2005), referência mundial no uso de games em educação, chama a atenção para a disparidade que a 
cultura do videogame pode gerar, em função de restrições de acesso para a população mais pobre e menos instrumentalizada. Apesar do atraso tecnológico, os alunos brasileiros estão começando a se favorecer pela presença das TICS que estão se tornando política pública em todo o Brasil, o que permite, cada vez mais, um crescente número de alunos, seja dentro ou fora da escola, podendo fazer uso de games educativos.

A pesquisa fez algumas referências sobre o nosso público-alvo, chamados de geração z, que já nasceu em um ambiente tecnológico digital. Foi provocante "me conectar" com seu universo, e pude concluir o quanto eles têm pouca paciência e são imediatistas. Por outro lado, são mais motivados, curiosos e dispostos a aprender. Sendo assim, precisam de mais interação, participação e atividades diferenciadas. Para chegar a essa conclusão, precisei estudar alguns autores como o educador holandês WinVeen (2012). Oportunamente, eu assisti a uma palestra sua e pude observar com outros olhos como jovens estudantes ficam conectados todo o tempo. Além de se manter conectado a diversas mídias, os alunos usam seus celulares com alguma frequência, para tirar fotos de conteúdos ou deveres de casa, escritos sobre os quadros negros ou brancos, ao invés de copiá-los no caderno. À medida que o preço desses pequenos computadores cai, eles vão se tornando onipresentes nas mãos dos aprendizes. Boa parte dos alunos já utilizam seus smartphones para trocar informações escolares com seus colegas de classe através do grupo da turma no Whatsapp, portanto, porque não incorporar esse dispositivo móvel como ferramenta educacional e desenvolver games educativos para esses dispositivos a fim de exercitá-los com os conteúdos de suas disciplinas escolares?

Uma parcela das instituições escolares públicas ainda não está instrumentalizada digitalmente, mas seus estudantes estão paramentados com seus smartphones ou com computadores ligados a internet em casa, na maioria dos domicílios brasileiros. Em função dessa realidade, Prensky (2010) e Mattar (2010) sugerem utilizar o espaço doméstico para iniciar o processo de renovação das metodologias educacionais. A pesquisa realizada demonstra que se os estudantes brasileiros dedicarem 50 minutos diários a games educativos, das 3,7 horas diárias que dedicam ao uso de diferentes mídias em casa, terão um ganho de um dia de aula por semana. 
Em pesquisa apresentada no Campus Party 2014 para a criadora de games Sioux, levantada pela Blend e o Núcleo de Estudos e Negócios em Marketing Digital da ESPM, foi feito um levantamento em que smartphones foram escolhidos por $83 \%$ dos entrevistados como melhor plataforma para se jogar e $82 \%$ dos pais costumam jogar games com seus filhos. Não surpreendentemente os alunos têm requisitado o movimento para levar a tecnologia para a sala de aula, mais que seus professores.

Essa e outras situações polêmicas são abordadas na pesquisa e ao me deparar com novos paradigmas para a metodologia educacional, tendo por base olivro “A escola tem futuro?” do educador português Rui Canário (2010), onde questiona, por que a escola, por se tratar de uma invenção humana recente, não pode ser reinventada?

Com os estudos que embasarem a presente dissertação, foi possível constatar o quanto se deve passar do modelo de aprendizado "adequado a todos”, em que estudantes de uma mesma turma usam o mesmo conteúdo e precisam aprender na mesma velocidade, para algo mais personalizado através de um ensino adaptativo, que leve em consideração o ritmo individual de cada estudante, onde uma das questões é a implementação de métodos de ensino baseados em mecânica de games.

Muitos games são produzidos com aderência a áreas de conhecimento e ao currículo escolar, entretanto, é sempre bom ressaltar que uma grande parcela de games produzidos para o mercado comercial também pode oferecer oportunidades de aprendizado de um aluno. Durante o processo de pesquisa foram selecionados, organizados e apresentados vários games que contribuem para a educação, sejam de entretenimento, sérios ou minigames, além dos educativos que foram elaborados e desenvolvidos para cumprir o propósito educacional. Infelizmente, não são muitos os títulos em língua portuguesa e é por essa razão que foram apresentados títulos estrangeiros reconhecidos e premiados em seus países por sua excelência e que servem de exemplo para demonstrar o que já é aplicado pelo mundo.

Em relação à contribuição dos games para a formação educacional, pude constatar uma valorização de algumas empresas e instituições sobre funcionários que tem o hábito de jogar. Prensky (2010), por exemplo, cita que estudos em hospitais mostram que os jogadores são cirurgiões melhores e em relação a outras 
áreas profissionais são indivíduos que buscam novas ideias e estratégias; têm melhor facilidade em superar crises e apresentam melhor poder de decisão. É com essa visão que o desenvolvedor de games canadense John Baker, em entrevista para o Jornal O GLOBO em janeiro de 2014, observa um estudo recente da Hart Research Associates que mais de três em cada quatro empregadores dizem que querem instituições de ensino que coloquem mais ênfase em ajudar os alunos a desenvolver os cinco principais resultados de aprendizagem: o pensamento crítico, solução de problemas complexos, comunicação escrita e oral, e aplicou conhecimento em contextos do mundo real.

Vindo ao encontro dessas demandas, a presente investigação buscou demonstar o quanto é necessário fomentar a interdisciplinaridade no desenvolvimento de games educativos. Tendo por base as ideias de Findeli (2001), analisou as reações das possíveis combinações entre a educação, design e tecnologia, e concluiu que quando se concretiza a interseção entre essas três áreas gera-se, acima de tudo, motivação para o seu público-alvo e a eficácia dos games como ferramenta de ensino-aprendizagem.

Sob essa perspectiva, baseei-me nos estudos do psicólogo húngaro MihalyCsikszentmihalyi para entender a experiência fenomenológica do fluxo, que é uma poderosa força motivacional. Essas ideias estavam em consonância com a essência da minha pesquisa, afinal o estado de fluxo visa o balanceamento entre o desafio e a habilidade do jogador, a fim de mantê-lo atraído e estimulado a concluir o desafio. Após entrar em contato com as pesquisas de Csikszentmihalyi, tive várias outras oportunidades de ler a respeito do estado de fluxo, pois o psicólogo é citado por vários outros autores.

Outro ponto que merece destaque é a constatação de valores agregados ao game educativo enquanto objeto digital de aprendizado. Conforme pesquisava e conceituava esse tema, fui ficando perplexo com a quantidade de valores que eu ia colecionando. Ao chegar próximo de 28 valores agregados ao game educativo procurei construir um organograma e pude checar o que mais se encaixava na estrutura que naturalmente se distribuiu em três partes: educacional ao centro, tecnologia à direita e científica (psíquica e física) à esquerda, não à toa, correlacionei com os lados direito e esquerdo do cérebro.

O percurso metodológico empreendido na pesquisa teve por base um levantamento bibliográfico digital e editorial envolvendo buscas e testes de games 
educativos e similares. A fim de compreender e identificar os diversos estilos e o quanto os games pesquisados poderiam acrescentar educacionalmente. A partir desse processo, elaborei a lista de recomendações de games com perfil educacional e cheguei ao momento mais importante e aguardado da presente pesquisa que foi o exercício de classificá-los e organizá-los dentro de uma estrutura taxonômica.

Foi uma tarefa trabalhosa, porém um prazeroso percurso para a elaboração da taxonomia, pois conforme eram definidas as nomenclaturas e as primeiras tabelas eram construídas, a sua estrutura foi ganhando formato. Exercitei troca de posições, exclusões e inclusões de itens e ocorreram alterações até que o glossário com todos os 94 itens estivesse concluído. A estrutura da taxonomia pareceu como um sistema orgânico em transformação. Entretanto, quando chegou a um determinado ponto e sua formatação ficou concluída, por mais que eu a revisasse, para a minha surpresa, não tive mais nenhuma alteração a fazer. Estava pronta!

Pronta para demonstrar a essência de um game educativo e para ser utilizada como referência em consulta de designers instrucionais, game designers e programadores na identificação de um game com conotação educacional, assim como, servir de base na criação de filtros de seleção de games em portais de objetos de aprendizado digitais.

E por falar em portais, se todos os games citados nessa pesquisa e mais os que fizeram parte dessa investigação e que não constam nesse documento compusessem um portal de games educativos para estudantes, pais e profissionais de educação o consultarem, a fim de descobrir que games estão disponíveis para contribuir no aprendizado do aluno, seria de grande valia para a sociedade do conhecimento que visa o desenvolvimento tecnológico, o envolvimento do aluno em seu próprio aprendizado e a renovação do formato atual de educação.

Tendo por base os estudos realizados para esta dissertação, constatei que existe uma demanda crescente de mais plataformas e portais com games educativos na língua portuguesa para proporcionar a estudantes, pais e profissionais de educação mais ferramentas que os apoiem pedagogicamente e que os envolvam em seu processo de ensino-aprendizado. Essa pesquisa, de certa forma, me faz sentir parte do desenvolvimento dos alunos do século XXI para um futuro desconhecido e de um grande avanço nas ciências e na 
tecnologia, no qual eles sobreviverão não por causa do que sabem, mas por causa de suas habilidades.

"Com os games educativos estamos buscando fundir o design, a educação e a tecnologia para inovar o ambiente de aprendizado, buscando soluções que envolvam tanto os alunos quanto os professores."

Roberto Todor, 2015 
7.

\section{Referência bibliografica}

ADAMS, E. Break into the Game Industry: How to get a job making video games. California: McGraw-Hill/Osborne, 2003.

AGUIAR, Michelle. Jogos Eletrônicos Educativos: instrumento de avaliação focado nas fases iniciais do processo de design. Dissertação apresentada ao Programa de Pós-Graduação em Design do Setor de Humanas da Universidade Federal do Paraná. Curitiba, 2010

ALVES, Lynn. Game Over: jogos eletrônicos e violência. São Paulo. Futura, 2005.

ANDRADE, G. D. Balanceamento Dinâmico de Jogos : Uma Abordagem Baseada em Aprendizagem por Reforço. De. Universidade Federal de Pernambuco. Pernambuco, 2006.

ARGAN, C.G. A história na metodologia do projeto. São Paulo: USP. 1983.

AZEVEDO, W. O que é design. 3. ed. São Paulo: Brasiliense, 1991.

BATTAIOLA, A. Jogos por Computador - Histórico, Relevância Tecnológica e Mercadológica, Tendências e Técnicas de Implementação. JAI2000, XIX JAI Jornada de Atualização em Informática do XIX Congresso Nacional da SBC. Paraná: 2000.

BOMFIM, Gustavo A. Sobre uma possibilidade de uma teoria do design. Estudos em Design. Ano II, Volume II. Rio de Janeiro, 1994.

BONSIEPE, G. Design: do material ao digital. Florianópolis: FIESC/IEL, 1997.

BORUCHOVITCH, E. O estilo motivacional do professor e a motivação intrínseca dos estudantes: uma perspectiva da teoria da autodeterminação Psicologia: Reflexão e Crítica, 2004.

BÜRDEK, B. E. Design: História, teoria e prática do design de produtos. 2. ed. São Paulo: Blucher, 2010.

CANÁRIO, Rui. A escola tem futuro? Das promessas às incertezas. São Paulo: Artmed, 2006.

CANDAU, Vera M. Da didática fundamentaql ao fundamental da didática. In: Maria Rita Neto Sales (org.) Alternativas no ensino da didática. São Paulo: Papirus, 1997. 
CRAWFORD, Chris. The Art of Computer Game Design. EUA: Osborne Media, 1984.

COSTA, L. D. O que os jogos de entretenimento têm que os jogos com fins pedagógicos não têm: princípios para projetos de jogos com fins pedagógicos. Rio de Janeiro, 2008. 120 f. Dissertação (Mestrado em Artes e Design) - Departamento de Artes e Design, Pontifícia Universidade Católica do Rio de Janeiro.

COUTO, Rita. M. S. O Movimento Interdisciplinar de Designers Brasileiros em Busca de Educação Avançada. Tese de Doutoramento. Departamento de Educação da Pontifícia Universidade Católica do Rio da Janeiro. Rio da Janeiro, 1997.

CSIKSZENTMIHALYI, Mihaly. The flow experience and its significance for human psychology. Cambridge, UK: Cambridge University Press, 1988.

CSIKSZENTMIHALYI, Mihaly A descoberta do fluxo: a psicologia do envolvimento com a vida cotidiana. Rio de Janeiro: Rocco, 1999.

DEFORGES, Y. Por um design ideológico. São Paulo: Estudos em Design: Volume 2, Número 1. 1994

FINDELI, A. Rethinking Design Education for the 21st Century: Theoretical, Methodological, and Ethical Discussion. São Paulo: Design Issues: Volume 17, Number 1. 2001

FLUSSER, V. O mundo codficado: por uma filosofia do design $e$ da comunicação. São Paulo: Cosac Naify. 2007.

FREIRE, J. B. Educação de corpo inteiro: teoria e prática da educação física. 4.ed. São Paulo: Scipione, 2006.

FOSTER, H. Design \& Crime. Londres: Verso, 2002.

GALLO, S. N. Jogo como elemento da cultura: aspectos contemporâneos e as modificações na experiência do jogar. São Paulo, 2007. 200 f. Tese (Doutorado em Comunicação e Semiótica) - Programa de Estudos Pós-Graduados em Comunicação e Semiótica, PUC- São Paulo.

GALVIN, P. B. Sistemas operacionais com Java. $7^{\text {a }}$ ed. Rio de Janeiro: Campus, 2008.

GARRETT, J. The elements of user experience: User-centred design for the web. New York: AIGA. 2003.

GEE, J. P. Why Video Games Are Good For Your Soul: Pleasure and Learning. Melbourne: Common Ground, 2005.

GOULARTE, Daniel. Jogos Eletrônicos: 50 anos de interação e diversão. Teresópolis: Novas Ideias, 2010. 
GREENFIELD, Patricia. O desenvolvimento do raciocínio na era da eletrônica: os

efeitos da TV, computadores e videogames. São Paulo: Sumus, 1988.

GRIFFITHS, M. D. (2002). The educational benefits of videogames. London: Education \& Health, Vol. 20, No.3, p.47, 2002.

HUIZINGA, Johan. Homo Ludens: o jogo como elemento da cultura. São Paulo: Perspectiva, 2007.

JENKINS, H. Cultura da convergência. São Paulo: Aleph, 2009.

KAMII, C. A criança e o número. $11^{a}$. ed. Campinas:Papirus, 1990.

LEITE, L. C. Jogos Eletrônicos Multi-Plataforma: compreendendo as plataformas de jogo e seus jogos através de uma análise em Design. Rio de Janeiro, 2006. 271p. Dissertação (Mestrado) - Departamento de Artes e Design, Pontifícia Universidade Católica do Rio de Janeiro.

LÉVY, Pierre. Cibercultura. 2.ed. São Paulo: Editora 34, 2000.

LÖBACH, B. Design industrial: bases para a construção dos produtos industriais. São Paulo: Blucher, 2001.

LYOTARD, J.F. O Pós-Moderno. José Olympo. Rio de Janeiro, 1986.

MANZINI, E., JEGOU, F. Sustainable everyday. Scenarios of Urban Life, Edizioni Ambiente. Milano, 2003.

MALONE, T. What makes computer games fun? In: ACM, 1980. P. 162-169.

MALONE, T.; LEPPER, M. Making Learning Fun: a taxonomy of intrinsic motivations for learning. Erlbaum: Hilsdale, NJ, 1987. P. 223-253.

MAMMEDE NEVES, A. Aprendendo Aprendizagem. Rio de Janeiro: PUC-Rio, Departamento de Educação/Laboratório Multimídia, 1999.

MARCELO, A.; PESCUITE, J. Fundamentos de design para jogos: um guia para o

projeto de jogos modernos reais e virtuais. Rio de Janeiro: Brasport, 2009.

MARX, C. Writing for Animation, Comics, and Games. USA: Focal Press, 2007. $226 \mathrm{p}$.

MATTAR, João. Games em educação: como os nativos digitais aprendem. Sâo Paulo: Pearsons Prentice Hall, 2010.

McGONIGAL, Jane. A realidade em jogo. Rio de Janeiro: Best Seller, 2012.

MEIGS, T. Ultimate game design: building game worlds. Emeryville, California: McGraw-Hill, 2003. 
MIRSOEFF, N. Una introducción a la cultura visual. Barcelona: Paídos, 2003.

MORAES, Anamaria. Ergonomia: Conceitos e aplicações. Rio de Janeiro: 2AB, 1998.

MYERS, B., ROSSON M. Survey on user interface programming. Proceedings SIGCHI'92: Human Factors in Computing Systems.

NOVAK, J. Desenvolvimento de Games. São Paulo: Cengage Learning, 2010.

PAPANEK, V. Design for the real world: human ecology and social change. Chicago: Academy Chicago Publishers, 2005.

PAPERT, S. Logo: computadores e educação. 3. ed. São Paulo: Brasiliense, 1986.

PAPERT, S. A Máquina das Crianças. Porto Alegre: Artes Médicas, 1994.

PIAGET, J. A formação do símbolo na criança: imitação, jogo e sonho, imagem e representação. 2. ed. Trad. Álvaro Cabral e Christiano Monteiro Oiticica. Rio de Janeiro: Zahar, 1975.

PONTE, J. P. Tecnologias de informação e comunicação na formação de professores: que desafios? Revista Iberoamericana de Educación. $\mathrm{N}^{\circ}$ 24. Lisboa: OEI, p. 63-90

PORTUGAL, C. Design, Educação e Tecnologia. Rio de Janeiro: Rio Books, 2013.

PREECE, J., ROGERS Y., SHARP H. Design e interação. São Paulo: Bookman, 2005.

PRENSKY, M. Aprendizagem baseada em jogos digitais. São Paulo: Editora Senac, 2012.

PRENSKY, M. “Não me atrapalhe, mãe - Eu estou aprendendo!”. São Paulo: Phorte Editora, 2010.

REEVES, T.; HARMON, S. Systematic evaluation for interactive multimedia for

education and training. In: Multimedia Computing: Preparing for the 21st Century. Hershey, PA: Publishing, 1994. p. 472-505.

ROLLINGS, A.; ADAMS, E. Game Design and Development: Fundamentals of Game Design. New Jersey: Prentice Hall, 2006.

ROUSE, R. Game Design: theory and practice. Plano, Texas: Wordware Publishing, 2001.

ROYO, J. Design Digital. São Paulo: Rosari, 2008. 
SILVA, C. E. M. Experiência com jogos digitais e causas sérias. In: Contemporânea. Rio de Janeiro. n. 11. ano VI. jul-dez. 2008.

SILVA, M. Sala de Aula Interativa. São Paulo: Edições Loyola, 2010.

VALENTE, J.A. org. Liberando a Mente: Computadores na Educação Especial. Campinas: Gráfica da UNICAMP, 1991

VAN ECK, R. COTS in the Classroom: A teachers guide to integrating commercial off-theshelf (COTS) games. In Richard Ferdig (ed) Handbook of research on effective electronic

gaming in education. Hershey, PA: Idea Group, 2008.

VAN ECK, R., Hung, W., Bowman, F., \& Love, S. 21st century game design: a model and prototype for promoting scientific problem solving. Proceedings of the International Association of Science and Technology for Development's annual Computers and Advanced Technology in Education Conference. St. Thomas: US Virgin Islands, 2009.

VEEN, Win. Homo Zappiens: educando na era digital. São Paulo: Artmed, 2001.

VYGOTSKY, L. S. A formação social da mente: o desenvolvimento dos processos psicológicos superiores. 6. ed. São Paulo: Martins Fontes, 1998.

XAVIER, G. Imagética Eletrolúdica: a visualidade dialógica no multiverso dos jogos eletrônicos. Rio de Janeiro, 2007. 195 f. Dissertação (Mestrado em Artes e Design) - Departamento de Artes e Design, Pontifícia Universidade Católica do Rio de Janeiro.

Dicionário Collins Português-Inglês e Inglês-Português. São Paulo: Editora Siciliano, 1991. 
Bibliografia Eletrônica (referências acessadas entre 03.2013 e 03.2015)

DEUBEL, P. Game on! Game based learning. Chatworth, E.U.A: T.H.E. Journal (Technological Horizons in Education), 2006.

<http://thejournal.com/Issues/2006/January-2006.aspx>

GAME BASED LEARNING INICIATIVE

$<$ http://gli.lsl.nie.edu.sg/publications/>

MINISTÉRIO DA EDUCAÇÃO. Guia de tecnologias educacionais. Org. Jeanete Beauchamp e Jane Cristina da Silva. Brasília: Ministério da Educação, Secretaria de Educação Básica, 2008b. 93 p.

$<$ http://portal.mec.gov.br/seb/arquivos/pdf/Avalmat/guia_de_tecnologias_educaci onais.pdf $>$

MONARK. Caverna do Dragão.

$<$ https://www.youtube.com/watch?v=lWb-Yd_N28E>

Links de games e portais citados na pesquisa:

ABC WORDS <http://www.technolio.com/>

ABC MOUSE <http://abcmouse.com>

ABCya! <http://www.abcya.com >

ALBERTA GOVERNMENT <http://www.learnalberta.ca>

ALPHABET CAR LITE < http://www.famigo.com>

BITESIZE <http://www.bbc.co.uk/bitesize/ks1/>

BLOODY TYPING GAME

<http://www.nobelprize.org/educational/medicine/bloodtypinggame>

BRAIN POP <http://www.brainpopjr.com>

BRAINRUSH < http://www.brainrush.com>

CAPOEIRA LEGENDS <http://www.capoeiralegends.com>

CIVILIZATION <https://www.civilization.com>

CUT THE ROPE <http://www.zeptolab.com/games/cut_the_rope/>

ESCOLA DIGITAL < http://escoladigital.org.br/tipo_midia/games/>

ESCOLA GAMES <http://www.escolagames.com.br/jogos.asp>

FUNBRAIN <http://www.funbrain.com/> 
FAZGAME <http://www.fazgame.com.br/>

FUNBRAIN <http://www.funbrain.com/>

KIDUCA <http://www.kiduca.com.br/>

LEARN ALBERTA <http://www.learnalberta.ca $>$

LETROCA < http://www.letroca-game.com>

LUDO EDUCATIVO <http://portal.ludoeducativo.com.br/pt/>

MINECRAFT $<$ https://minecraft.net/ $>$

MIT GAME LAB |http://gamelab.mit.edu/>

MITO DA CAVERNA <http://www.omitodacaverna.com.br $>$

MY MATH <http://www.mymath.co.uk/>

MANGAHIGH <https://www.mangahigh.com/pt-br >

OJE - Olimpíadas de Jogos Digitais <http://www.oje.inf.br/acre/app/index>

OPERAÇÃO COSMOS <http://redalgo.com/demoF.html >

PHET <http://phet.colorado.edu/en/simulations/category/new >

SMART KIDS < http://www.smartkids.com.br $>$

SMART NOTEBOOK < http://www.education.smarttech.com/?wt.ac=homepage_ed>

THE SIM CITY <http://www.simcity.com>

TOCA TEA PARTY <http://tocaboca.com/game/toca-tea-party/>

TRÍADE <http://www.clickjogos.com.br/downloads/triade/>

VIVAZ - O jogo do conhecimento <http://www.livrariasaraiva.com.br/>

WORLD MATH DAY <http://www.3plearning.com/worldeducationgames/>

ZOO TYCOON <http://zoo-tycoon.softonic.com.br/>

Links de associações e eventos citados na pesquisa:

ABRAGAMES | http://www.abragames.org/

BIG FESTIVAL | www.bigfestival.com.br

BRASIL GAME SHOW | http://www.brasilgameshow.com.br

BETT BRASIL EDUCAR | http://www.bettbrasileducar.com.br/

GAMES4CHANGE | http://www.gamesforchange.org/

SBGAMES | http://www.sbgames.org 